\title{
A COMPARISON OF RURAL AND URBAN FLUVIAL SYSTEMS AS A FUNCTION OF LAND COVER CHANGES IN SUMMIT COUNTY, OHIO
}

\author{
A Thesis \\ Presented to \\ The Graduate Faculty of The University of Akron
}

\author{
In Partial Fulfillment \\ of the Requirements for the Degree \\ Master of Science
}

Andrea M. Rocchio

May, 2017 


\section{A COMPARISON OF RURAL AND URBAN FLUVIAL SYSTEMS AS A FUNCTION OF LAND COVER CHANGES IN SUMMIT COUNTY, OHIO}

Andrea M. Rocchio

Thesis

Approved:

Accepted:

Advisor

Dr. John A. Peck

Interim Dean of the College

Dr. John Green

Faculty Reader

Dean of the Graduate School

Dr. John M. Senko

Dr. Chand Midha

Faculty Reader

Date

Dr. Linda R. Barrett

Interim Department Chair

Dr. Stephen C. Weeks 


\begin{abstract}
Population growth during the 20th century in Northeast Ohio has led to an overall increase in developed land cover and anthropogenic pollution such as fossil fuel combustion. Urban expansion and fossil fuel combustion result in an increase of polluted runoff into fluvial systems, which jeopardizes water quality, undermines infrastructure, and stresses local ecosystems that buffer floods. This study compares heavy metal pollution levels and land cover change during the 20th century in dammed impoundments within the rural Haskell Run watershed (Lake Butler), the rural Ritchie Run (Lake Litchfield), and the urban Mud Brook watershed (Old Mill Pond) in Northeast Ohio. Surficial sediment samples were collected from each impoundment to assess current pollution levels and sediment cores were collected for the past record of pollution. The two end-member watershed types have similar bedrock, glacial history, and climate, however, land cover differs greatly. Between 1985-2010, there was no land cover change in the rural Ritchie Run watershed, and in 2010, Ritchie Run had 3.4\% developed land cover and 0.63\% impervious cover. During the same period, the rural Haskell Run watershed increased by 1.37\% in developed land cover, and in 2010, 12\% of the Haskell Run watershed was developed land and 3.3\% was impervious cover. Developed land cover, from 1985-2010, increased by $15.3 \%$ in the urban Mud Brook watershed, and in 2010, 74\% was developed land cover and 23\% was impervious cover. Old Mill Pond impoundment sediments were found to have higher heavy metal and ferrimagnetic concentrations, whereas, Lakes Butler and Litchfield sediments have comparatively lower heavy metal and ferrimagnetic concentrations. There is a moderate direct relationship
\end{abstract}


between heavy metal and ferrimagnetic content. Therefore, magnetics can be used as an inexpensive and rapid screening tool for heavy metal pollution studies. The Old Mill Pond sediment core records an increase in heavy metal and ferrimagnetic concentration in the early 20th century, peaking in the 1940s-1960s when Cuyahoga Falls experienced a doubling in population. Since the 1970s-1980s, after the Clean Air Act (1970) and Clean Water Act (1972) were enacted, the heavy metal and ferrimagnetic concentrations decreased to present-day. The study supports that more developed land cover and impervious surfaces in a watershed lead to higher levels of anthropogenic related pollutants in fluvial systems. Sediment cores and aerial photographs from Lakes Butler and Litchfield indicate a history of both delta progradation and flood events. Studies, such as this, can assist in informing local policy makers and land managers when considering the effects of urban expansion, preservation of ecosystems and undeveloped spaces, and the effectiveness of national and local environmental regulations. 


\section{ACKNOWLEDGEMENTS}

Obtaining a master's degree is a long and arduous process, and aside from my own efforts, there were many people who helped me to reach this important goal. I first would like to extend special thanks to my advisor, Dr. John Peck, for his advice, guidance, and direction throughout the thesis process. I also would like to thank my committee members, Dr. John Senko, Dr. Linda Barrett, and Dr. John McManus for their advice and insights during my time here at the University of Akron. I wish to thank Elaine Butcher and Thomas Quick for all their much-appreciated assistance, guidance, and knowledge for lab and computer work, as well as the kindness they've shown me. I would like to extend a thank you to Kelsey Budahn, Sarah Eblin, Adam Delaney, Justin Gilbow, and Nick Wander for their assistance in the field, especially during times of hail and snow. A special thank you goes to Unity Health Network, City of Cuyahoga Falls, and the personnel at Camp Manatoc for access to the impoundments.

I want to give another special thank you to my parents, Ellen and Joe, my sister Erin, and my boyfriend Dylan for their constant, undying support, editing, and advice throughout the process of getting my master's degree. Thank you to my graduate school friends Kelsey Budahn, Sarah Eblin, Lindsay Starr, Kim Landrith, Corrine Lally, Julian Grochocki, and Adam Delaney for the advice and memories that I will cherish for years to come. 
TABLE OF CONTENTS

Page

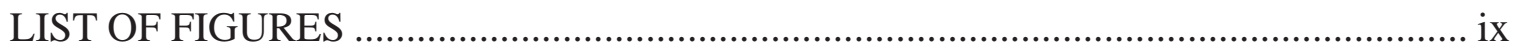

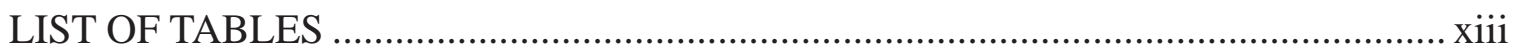

\section{CHAPTER}

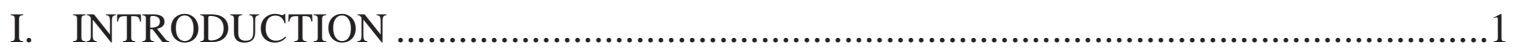

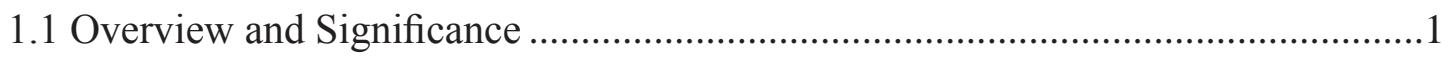

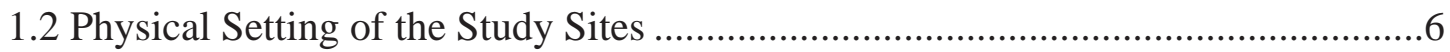

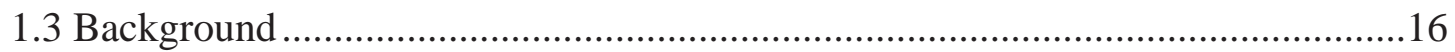

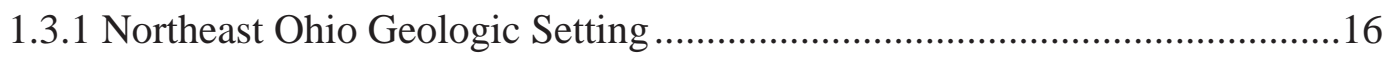

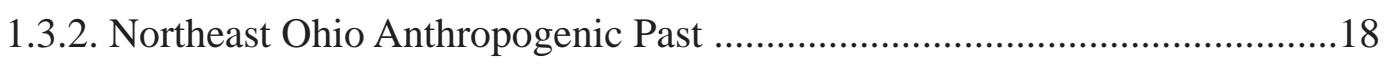

1.3.3 Climate Change in Northeast Ohio .......................................................21

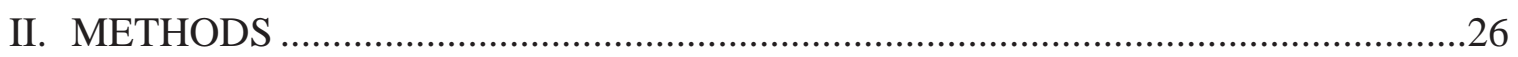

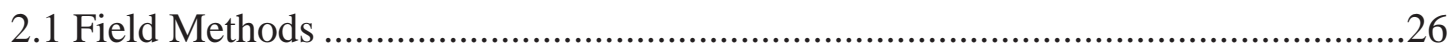

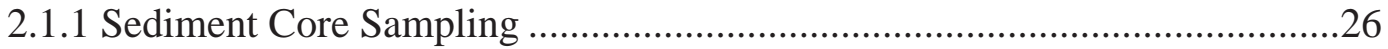

2.1.2 Surface Sediment Sampling ...............................................................33

2.1.3 Trapping Efficiency and Stream Discharge of Lake Butler .........................33

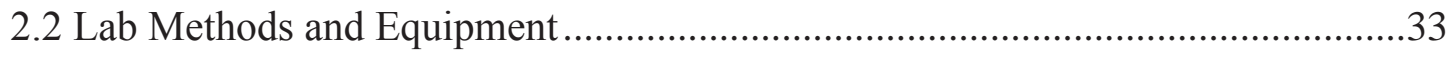

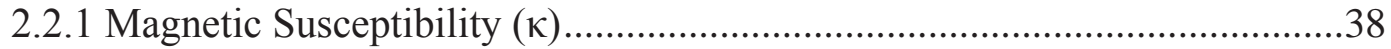

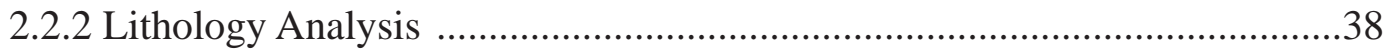

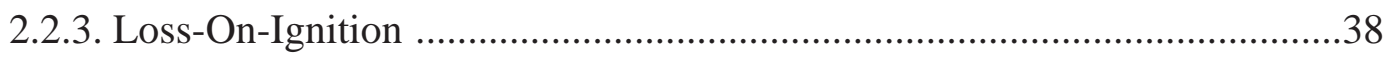

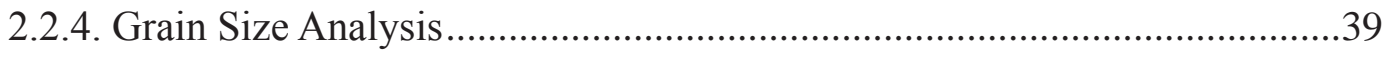

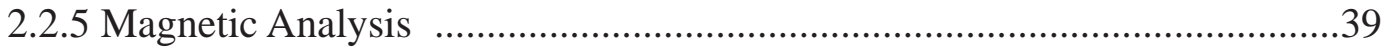

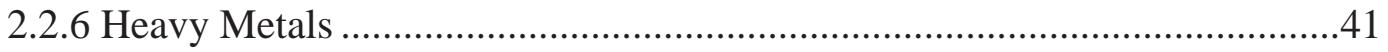




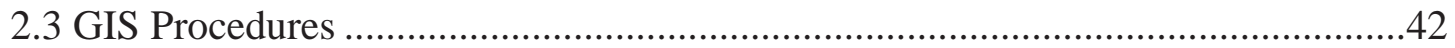

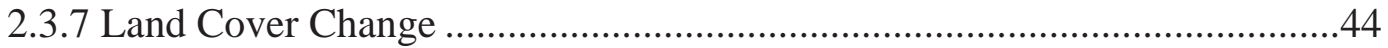

2.3.8 Shoreline Assessment.....................................................................46

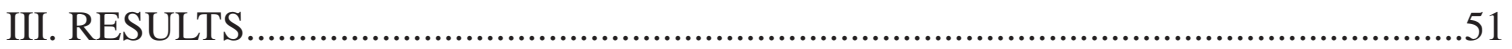

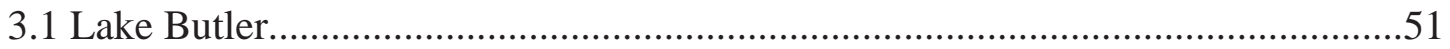

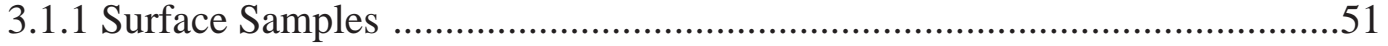

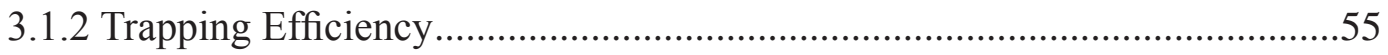

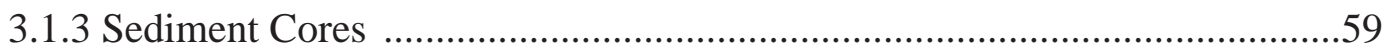

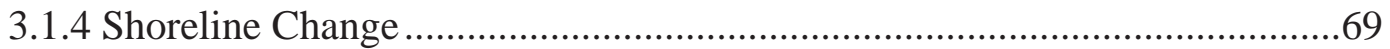

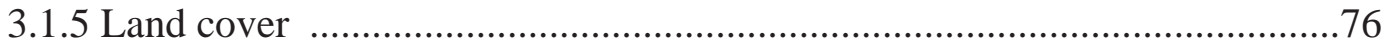

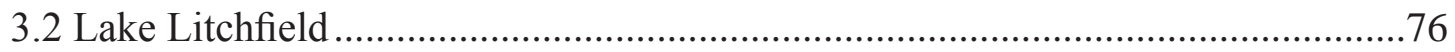

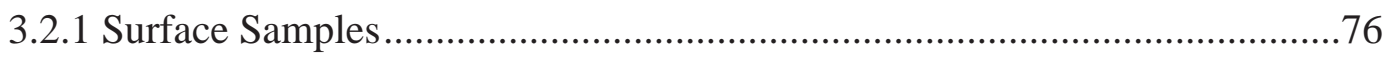

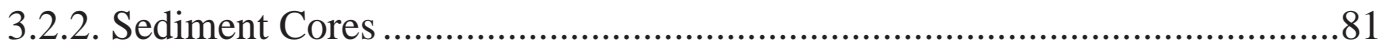

3.2.3 Shoreline Change ..............................................................................97

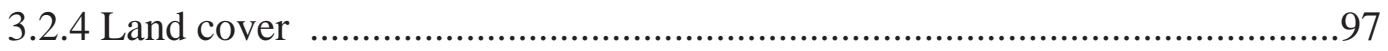

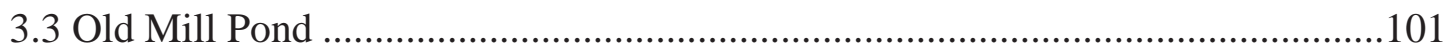

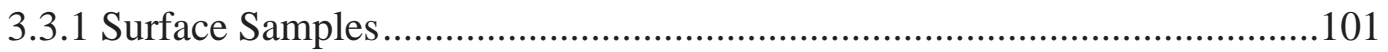

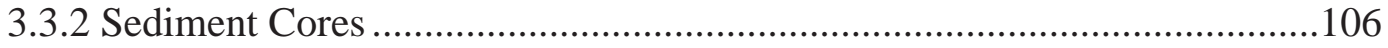

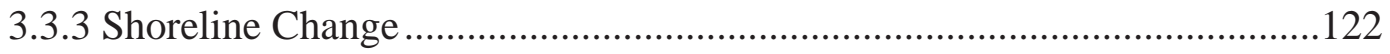

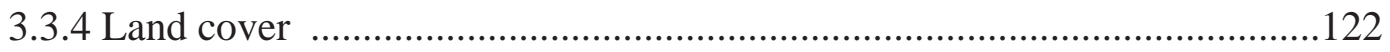

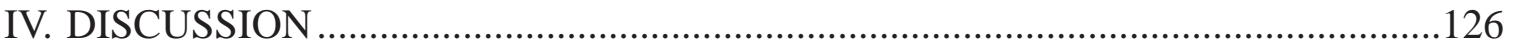

4.1 The Impact of Watershed Development on Pollution in Fluvial Systems ..........126

4.2 Sediment Magnetism as a Pollution Proxy ........................................................131

4.3 Historical Changes Recorded in the Impoundment Sediment ...........................137

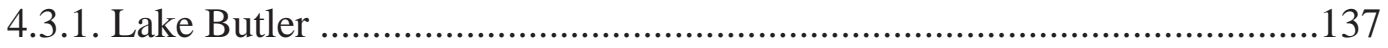

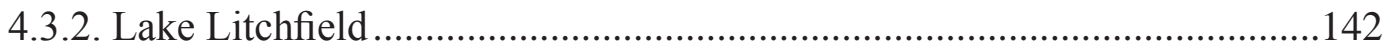

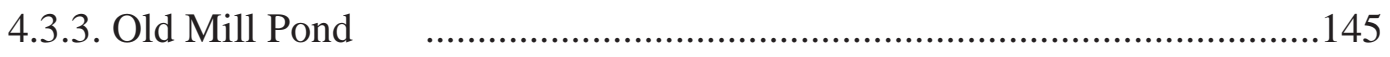


V. CONCLUSIONS.

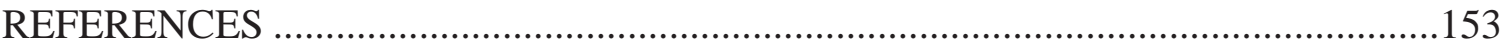

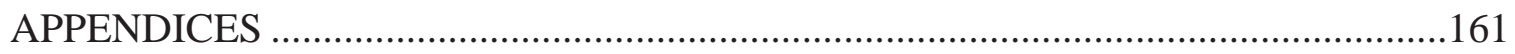

APPENDIX A. HASKELL RUN DISCHARGE AND TOTAL SUS-

PENDED SEDIMENT.

APPENDIX B. SEDIMENT CORE LOSS-ON-IGNITION AND

WHOLE CORE SUSCEPTIBILITY (K) FOR LAKE BUTLER, LAKE

LITCHFIELD, AND OLD MILL POND

APPENDIX C. SEDIMENT CORE AND SURFACE SAMPLE MAGNETIC PROPERTIES FOR LAKE BUTLER, LAKE LITCFIELD, AND OLD MILL POND.

APPENDIX D. INDIVIDUAL SEDIMENT CORE LITHOLOGY AND SEDIMENT PROPERTIES FOR LAKE BUTLER, LAKE LITCFIELD, AND OLD MILL POND

APPENDIX E. LAND COVER CHANGE FOR HASKELL RUN, RITCHIE RUN, AND MUD BROOK.

APPENDIX F. GRAIN SIZE DATA FOR SEDIMENT CORE AND SURFACE SAMPLES FOR LAKE BUTLER, LAKE LITCHFIELD, AND OLD MILL POND 


\section{LIST OF FIGURES}

Figure

Page

$1 \quad$ Watersheds for the three study impoundments (Butler, Litchfield, and Old Mill Pond) within the Cuyahoga River watershed in Northeast Ohio (US Census, 2015; ESRI, 2017; USDA, 2017)

$2 \quad$ Aerial photo showing Lake Butler in the Haskell Run watershed and Lake Litchfield in the Ritchie Run watershed (ESRI, 2016

3 Aerial photo showing Old Mill Pond in the middle Mud Brook watershed (ESRI, 2016).

$4 \quad$ Map of the Haskell Run and Ritchie Run watersheds showing low impact farming or undeveloped land from the Summit County Atlases of 1910, 1936, and 1951 (The Rectigraph Abstract and Title company, 1910; Sidwell Studio 1936; Sidwell Studio 1951)

$5 \quad$ Haskell Run and Ritchie Run in 1994, 2006, and 2015

6 Figure from the newspaper account of the Park Tire Co. tire fire in the Haskell Run watershed on Wednesday, August 6, 1981 (The Cleveland Press, 1981).

$7 \quad$ Map showing Old Mill Pond and the surrounding development (ODNR, 2017)

$8 \quad$ The middle Mud Brook watershed and old Mill Pond dam from 19101951 (The Rectigraph Abstract and Title company, 1910; Sidwell Studio, 1936; Sidwell Studio, 1951)

9 (Top) The "Iron Bridge" in Cuyahoga Falls, picture taken in the late 19th century (SCHS, 2008)

10 The middle Mud Brook watershed and old Mill Pond dam showing suburban development between 1994-2015 (Summit County Parcel Viewer, 2016)

11 Figure from a news paper article report on the continued development surrounding Old Mill Pond

12 Conceptual model depicting land use changes, channel conditions, and sediment yield response (Modified after Wolman, 1967) 
13 Mean daily discharge of the Cuyahoga River at the Old Portage Path gage station in Old Portage, Ohio

14 Lake Butler surface sediment samples, core sites, and stream discharge measurement locations overlain on a 2015 aerial photo (ESRI, 2016a)

15 Lake Litchfield surface sediment samples and core sites overlain on a 2015 aerial photo (ESRI, 2016a

Old Mill Pond surface sediment samples and core sites overlain on a 2015 aerial photo (ESRI, 2016a)

17 Examples of poor, good to fair, and excellent photo quality for Old Mill Pond. Refer to Table 14 for photo quality ranking of all photo year

Detailed lithology description for Lake Butler sediment core LB-16-C4.

19 Lithology, whole core susceptibility ( $\kappa)$, organic matter, and dry bulk density for Lake Butler delta top core LB-16-C4

20 Down core profiles of Lake Butler delta top core (C4) showing lithology, magnetic concentrations (SIRM), and $\mathrm{Pb}, \mathrm{Zn}, \mathrm{Cu}$, and $\mathrm{Cr}$ heavy metal concentrations

21 Lithology and magnetic concentration profiles for Lake Butler delta top core C4

22 Lithology, magnetic grain size $(\chi \mathrm{fd} \%$ and $\chi \mathrm{ARM} / \chi, \mathrm{SIRM} / \chi)$, and magnetic minerology (S-ratio) profiles for Lake Butler delta top core C4.

23 Dearing Plot for surficial samples and core samples from the three site impoundments

24 Detailed lithology description for core pro-delta Lake Butler core LB-16-C7 _.......67

25 Lithology, whole core susceptibility $(\kappa)$, organic matter, and dry bulk density for Lake Butler pro-delta lake floor core LB-16-C7..

26 Haskell Run and the Lake Butler delta in 1994 and 2000

27 Haskell Run and the Lake Butler delta in 2003 and 2005

Haskell Run and the Lake Butler delta in 2006 and 2010.

Haskell Run and the Lake Butler delta in 2012 and 2014

31 Land cover change in the Haskell Run watershed from 1985-2010 
33 Lithology, whole core susceptibility ( $\kappa)$, organic matter, and dry bulk density for Lake Litchfield pro-delta core LL-16-C1

34 Down core profiles of Lake Litchfield pro-delta core (C1) showing lithology, magnetic concentration (SIRM), and $\mathrm{Pb}, \mathrm{Zn}, \mathrm{Cu}$, and $\mathrm{Cr}$ heavy metal concentrations

35 Lithology and magnetic concentration profiles for Lake Litchfield prodelta core $\mathrm{C} 1$

36 Lithology, magnetic grain size $(\chi \mathrm{fd} \%, \chi \mathrm{ARM} / \chi, \mathrm{SIRM} / \chi)$, and magnetic minerology (S-ratio) profiles for Lake Litchfield core C1. See Figure 32 for lithology description.

37 Detailed lithology description for Lake Litchfield sediment core LL-16-C2

Lithology, whole core susceptibility $(\kappa)$, organic matter, and dry bulk density for Lake Litchfield core C2

Lake Litchfield delta in 1994 and 2000

Lake Litchfield delta in 2003 and 2005

41 Lake Litchfield delta in 2006 and 2010

42 Lake Litchfield delta in 2012 and 2014

43 Lake Litchfield delta in 2015 and 2016

44 Land cover change from 1985-2010 in the Ritchie Run watershed (Digital Coast, 2016a)

45 Old Mill Pond surface sediment values for A) dry bulk density (g/ $\left.\mathrm{cm}^{3}\right)$, B) susceptibility frequency dependance $(\%)$, C) magnetic susceptibility $\left(10^{-8} \mathrm{~m}^{3} \mathrm{~kg}^{-1}\right)$, and D) $\mathrm{Pb}$ content $(\mu \mathrm{g} / \mathrm{g})$.

46 Detailed lithology description for core Old Mill Pond sediment core OMP-16-C3

47 Lithology, whole core susceptibility $(\kappa)$, organic matter, and dry bulk density, for Old Mill Pond core OMP-16-C3 obtained from the middle of the impoundment

48 Down core profiles of Old Mill Pond middle impoundment core (C3) showing lithology, magnetic concentrations (SIRM), and $\mathrm{Pb}, \mathrm{Zn}, \mathrm{Cu}$, and Cr heavy metal concentrations

Lithology and magnetic concentration profiles for Old Mill Pond core C3.

$50 \quad$ Lithology, magnetic grain size $(\chi \mathrm{fd} \%, \chi \mathrm{ARM} / \chi, \mathrm{SIRM} / \chi)$ and magnetic minerology (S-ratio) profiles for Old Mill Pond core C3. 
51 Detailed lithology description for Old Mill Pond sediment core OMP-16-C5 114

52 Lithology, whole core susceptibility ( $\kappa)$, organic matter, and dry bulk density, for Old Mill Pond sediment core OMP-16-C5.

53 Old Mill Pond delta in 1994 and 2000

54 Old Mill Pond delta in 2003 and 2005

55 Old Mill Pond delta in 2006 and 2010

56 Old Mill Pond delta in 2012 and 2014

57 Old Mill Pond delta in 2015 and 2016

58 Land cover change in the Mud Brook watershed from 1985-2010

(Digital Coast, 2016a)

59 Box and whiskers plot of $\mathrm{Pb}, \mathrm{Zn}, \mathrm{Cu}$, and $\mathrm{Cr}$ heavy metal concentrations for Lake Butler $(n=5)$, Lake Litchfield $(n=5)$, and Old Mill Pond $(\mathrm{n}=10)$.

60 Box and whiskers plots of magnetic susceptibility $(\chi)$ ranges, a sediment magnetic parameter, for all surface samples for Lake Butler $(\mathrm{n}=14)$, Lake Litchfield $(\mathrm{n}=13)$, and Old Mill Pond $(\mathrm{n}=13)$

61 SIRM, a magnetic concentration parameter, versus heavy metal concentration of $\mathrm{Pb}, \mathrm{Zn}, \mathrm{Cu}$, and $\mathrm{Cr}$ for Lake Butler, Lake Litchfield, and Old Mill Pond long core and surface sediment samples.

62 Modified Dearing Plot for surficial samples and core samples from the three site impoundments

63 Summary figure for Lake Butler delta top core (LB-16-C4) showing lithology, dry bulk density (DBD), saturation isothermal remanent magnetization (SIRM), and $\mathrm{Pb}$ and $\mathrm{Zn}$ concentrations...

64 Summary figure for the Lake Litchfield delta front core (LL-16-C1). This figure shows the lithology, dry bulk density (DBD), saturation isothermal remanent magnetization (SIRM), and $\mathrm{Pb}$ and $\mathrm{Zn}$ concentrations

65 Sedimentary structures at Lake Litchfield delta on November 21, 2016

66 Summary figure for Old Mill Pond sediment core 3 showing lithology, dry bulk density (DBD), saturation isothermal remanent magnetization (SIRM), and $\mathrm{Pb}$ and Zn concentrations 


\section{LIST OF TABLES}

Table

Page

1 Top ten historic crests of the Cuyahoga River (NOAA, 2016a) and wettest years in Akron, OH (NOAA, 2016b).

2 Number of high flow events on the Cuyahoga River at Old Portage Path, Ohio in 13-year intervals since 1921(USGS, 2016a)

3 Sediment cores collected from Lake Butler near Peninsula, $\mathrm{OH}$

4 Sediment core samples at Lake Litchfield near Peninsula, $\mathrm{OH}_{\text {. }}$ 31

5 Sediment core samples at Old Mill Pond in Cuyahoga Falls, $\mathrm{OH}$

6 Surface sediment samples collected from Lake Butler near Peninsula, OH on March 25, 2016

$7 \quad$ Surface sediment samples collected from Lake Litchfield near

Peninsula, OH taken May 15, 2016

8 Surface sediment samples collected from Old Mill Pond in Cuyahoga

Falls, OH taken May 9, 2016

$9 \quad$ Lake Butler inflow and outflow discharge measurement locations

10 Time intervals and depths in the graduated cylinder for extracting silt and clay of known sizes. (Folk, 1980)

11 A. Two acid blanks and Buffalo River reference material \#8704 denoting the concentrations of lead $(\mathrm{Pb})$, zinc $(\mathrm{Zn})$, copper $(\mathrm{Cu})$, and chromium (Cr)

12 GIS data types, sources, and their purpose to complete the thesis

13 Impervious coefficients derived from population density (population/ sq. mi.) from the NOAA Impervious Surface Analysis Tool (ISAT) and NLCD (2006) impervious data

14 Aerial orthophotos used to assess shoreline change, organized by year

15 Magnetic and physical properties of Lake Butler surface samples collected March 25, 2016. 
16 Lake Butler summary table of grain size analysis for representative samples 53

17 Heavy metal concentrations for selected Lake Butler sediment samples _................... 54

18 Magnetic properties for Lake Butler surface samples and core samples _................... 56

19 Lake Butler lake level relative to the year 2000 water level.

20 Haskell Run land cover and land cover change summary table for the years 1985, 1996, 2001, 2006, and 2010 78

21 Magnetic and physical properties of Lake Litchfield surface samples and core samples.

22 Heavy metal concentrations for selected Lake Litchfield sediment samples _..........80

23 Lake Litchfield summary table of grain size analysis for representative samples. The $\mathrm{D}_{50}$ is the median.

24 Lake Litchfield lake level relative to the year 2000 water level _...............................95

25 Delta growth from 1994 to 2015 at Lake Litchfield 98

26 Ritchie Run land cover and land cover change summary table for the years 1985, 1996, 2001, 2006, and 2010

$27 \quad$ Magnetic and physical properties of Old Mill Pond surface samples and core samples

28 Old Mill Pond summary table of grain size analysis for representative samples

29 Heavy metal concentrations for selected Old Mill Pond sediment samples _.......... 104

30 Lake water level relative to the concrete structure in Old Mill Pond

31 Old Mill Pond land cover and land cover change summary table for the years 1985, 1996, 2001, 2006, and 2010. 


\section{CHAPTER I}

\section{INTRODUCTION}

\subsection{Overview and Significance}

Population growth and urban expansion within the Cuyahoga River watershed has contributed to an increase in developed land cover and anthropogenic pollution, namely fossil fuel combustion products. Land cover and pollution changes impact local fluvial systems and influence sediment delivery, geomorphology, and pollution levels captured in the sediment record. The goal of this research project is to evaluate differences in sediment delivery and sediment type from subwatersheds of the Cuyahoga River having contrasting land cover change histories. Numerous studies have successfully utilized sediment core, GIS, and watershed ecology analysis to assess the anthropogenic impacts of the 20th century land cover changes on the fluvial environment (Peck et al., 2007; Muller et al., 2009; Mann et al., 2013; Shaw, 2013; Kibene et al., 2014; Webb-Sullivan and Evans, 2014; Lin et al., 2015).

The two subwatersheds of the Cuyahoga River for this thesis, Haskell Run/Ritchie Run and Mud Brook, are both located in Summit County, Ohio (Figure 1). Haskell Run/ Ritchie Run and Mud Brook have similar slopes, climate, glacial history, and underlying bedrock; however, they have contrasting land cover change histories. The Haskell Run/ Ritchie Run watersheds have remained largely undeveloped and contain two dammed impoundments called Lake Butler and Lake Litchfield (Figure 2), whereas the middle Mud Brook watershed is highly developed and contains a dammed impoundment called Old Mill Pond (Figure 3). These impoundments provide sediment records spanning the last half-century. 


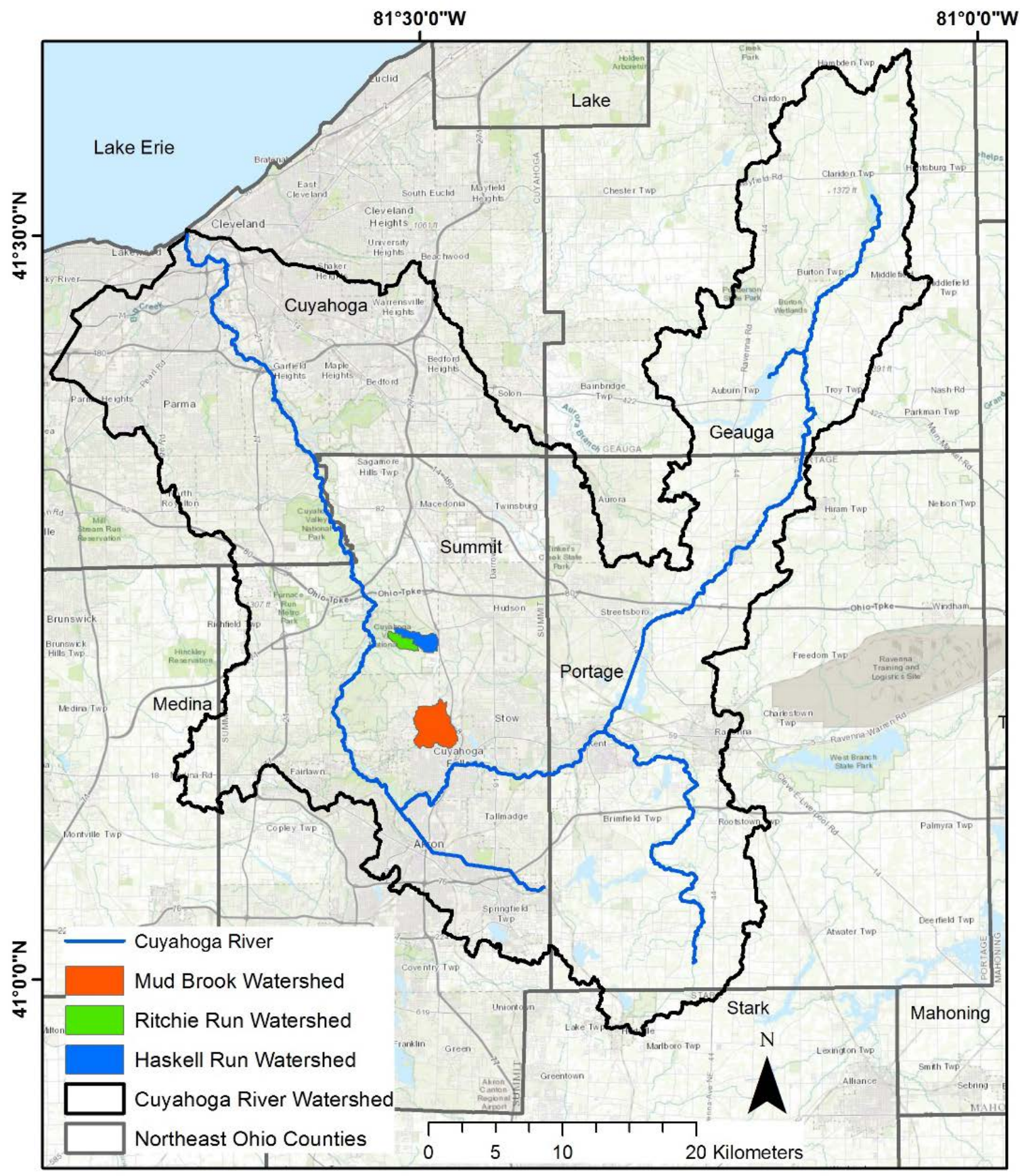

Figure 1. Watersheds for the three study impoundments (Butler, Litchfield, and Old Mill Pond) within the Cuyahoga River watershed in Northeast Ohio (US Census, 2015; ESRI, 2017; USDA, 2017). 


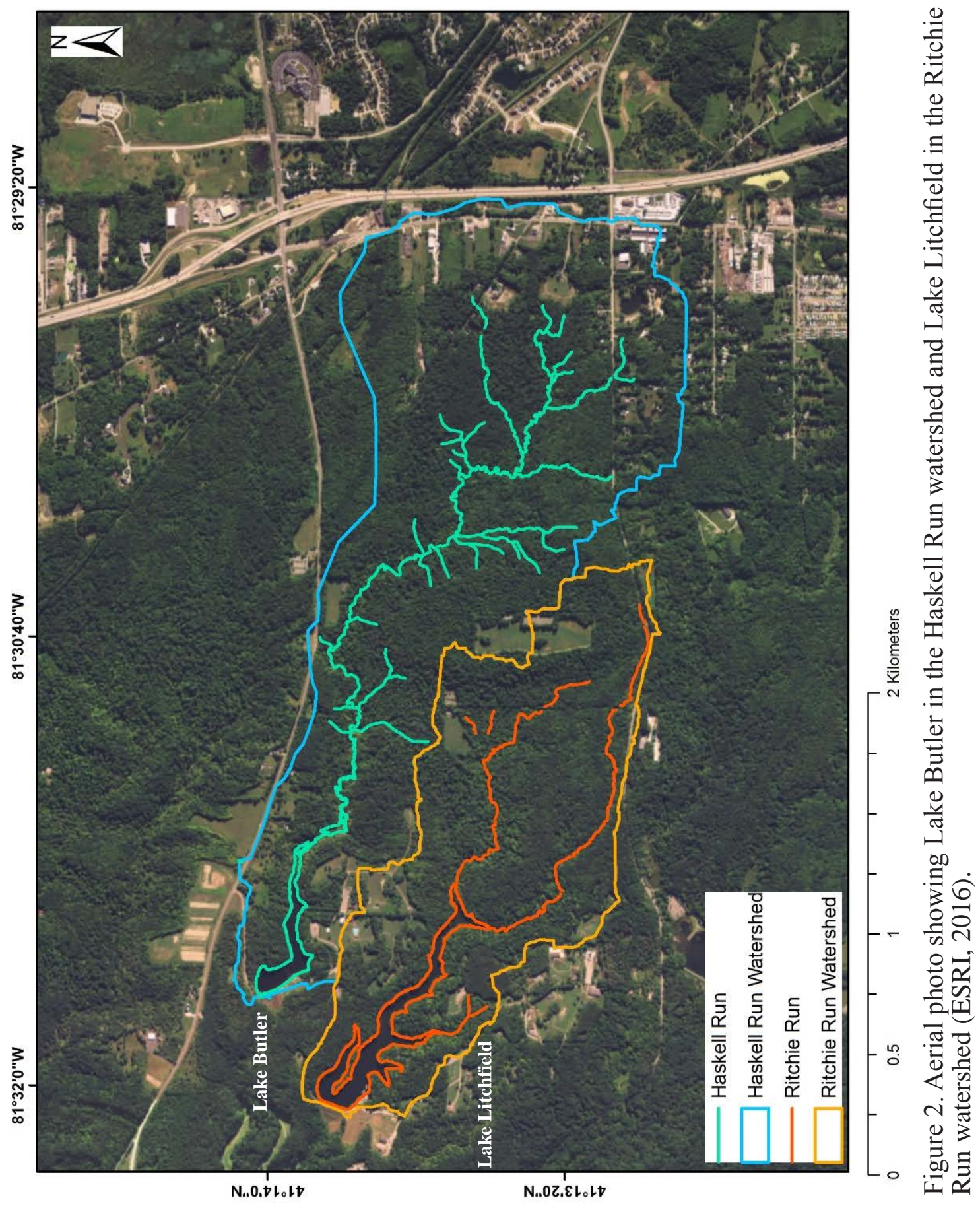


My first hypothesis is that the Old Mill Pond sediment will contain elevated levels of heavy metals and ferrimagnetic particles due to increased urbanization in the Mud Brook watershed, whereas Lakes Butler and Litchfield sediment will have comparatively low levels of heavy metals and ferrimagentic particles owing to less development in the Haskell Run/Ritchie Run watersheds. Combustion pollution often has high concentrations of coarse-grained ferrimagnetic particles (Evans \& Heller, 2003). Thus, I have an additional research question that will determine if sediment magnetic properties can be used as a pollution proxy.

Since July 2003, there has been an increase in the frequency of heavy precipitation and flooding events in Northeast Ohio (Liberatore, 2013). Increased precipitation and flooding often leads to higher rates of sedimentation and higher energy conditions that transport larger particles. My second hypothesis is that increased sedimentation and larger grain sizes will occur in the impoundments of both watersheds due to more frequent flooding since 2003.

To address these hypotheses, land cover change through time was assessed. Sediment samples from each impoundment were collected and analyzed for grain size, physical properties, heavy metals, and magnetic properties. Changes to the shoreline of the deltas in each impoundment were assessed using a series of aerial photographs (Google, 2016; Summit County Fiscal Office, 2016; Summit County Parcel Viewer, 2016; USGS, 2016b).

With a changing regional climate, strategic planning based in scientific research is critical to support better-informed local policy regarding people and ecosystems (Cook et al., 2014). This study will afford new insights into sedimentation in the Cuyahoga River by examining watersheds with contrasting land cover. 


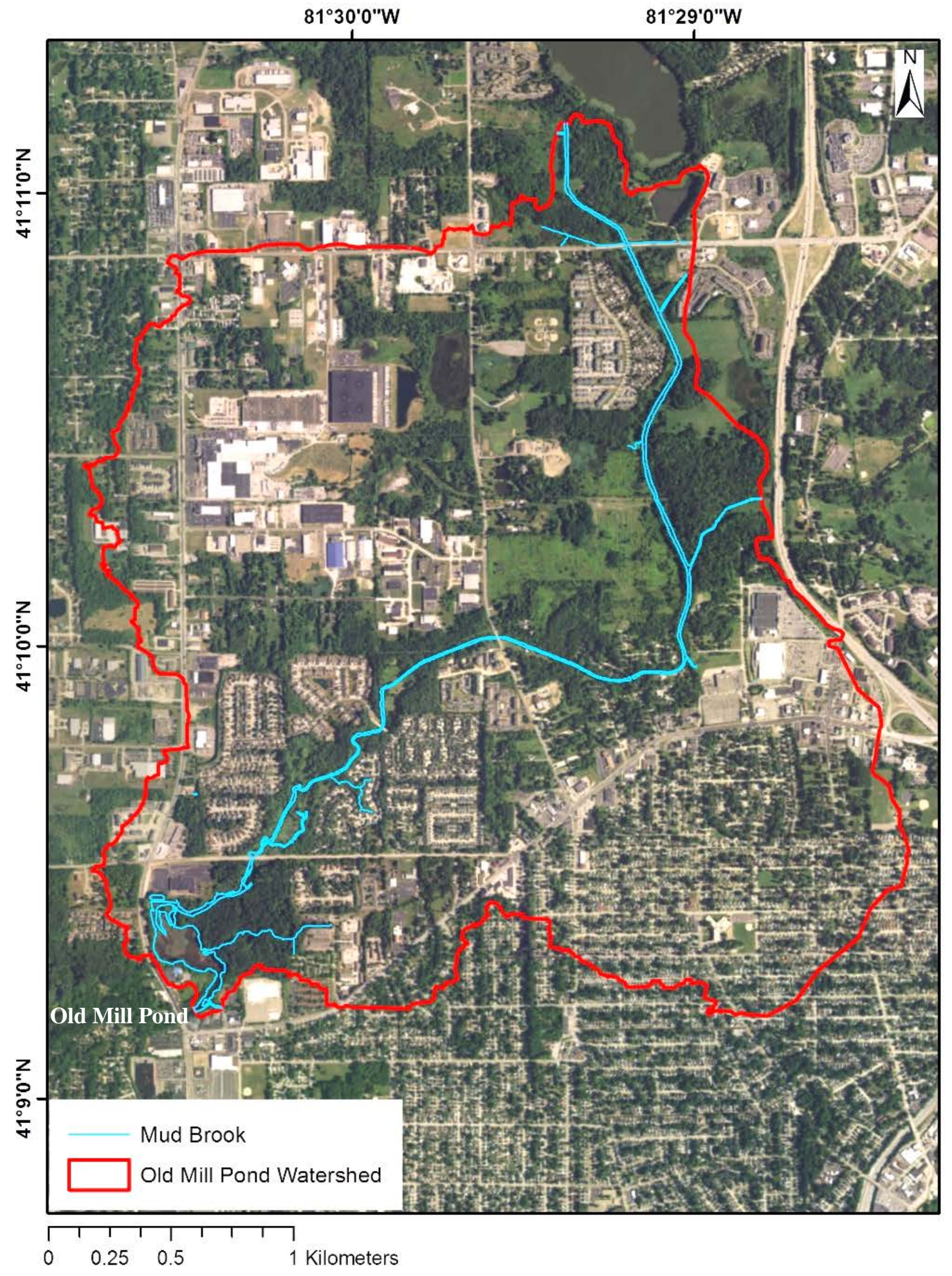

Figure 3. Aerial photo showing Old Mill Pond in the middle Mud Brook watershed (ESRI, 2016). 


\subsection{Physical Setting of the Study Sites}

Two watersheds, one rural and one urban, each with dammed impoundments, were selected for study (Figures 2 and 3). Both watersheds are located in Summit County, Ohio, and drain into the Cuyahoga River. Owing to their close proximity, the two watersheds have been subjected to similar increases in precipitation and flooding events since July 2003.

Haskell Run (Lake Butler) and Ritchie Run (Lake Litchfield) are two rural watersheds adjacent to each other. For the purposes of this project, they are both considered to be the rural endmember watershed type (Figure 2). The Lake Butler dam was constructed between 1958 to 1963, and the Lake Litchfield dam was built in 1975 and the water level was raised for boating around 1977-1978 (Cardwell, 2016; Bergdorf R., 2016). The Lake Butler dam is $95 \mathrm{~m}$ (310 ft) wide and $15 \mathrm{~m}$ (50.7 ft) tall with a normal pool area over

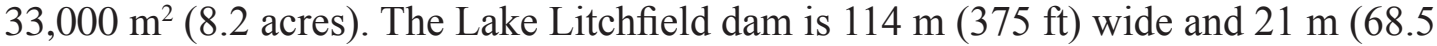
ft) tall and has a normal pool area over 105,000 m² (26 acres). Both dam structures are constructed of earthfill (ODNR, 2016).

Lakes Butler and Litchfield lie within Boy Scouts of America property (Camps Manatoc and Butler), established circa 1922 by Karl Butler and Dwight Ramsey (Davis, 2013). Camps Manatoc and Butler are located in Boston Township and are surrounded by the Cuyahoga Valley National Park. In the 1990s, the National Park Service proposed an easement to prevent the Boy Scout Council’s campgrounds from being developed (Downing, 1992). In 1994, the National Park Service paid \$1.75 million to the Boy Scout Council to aid the organization in preserving its 600 acres and assisting in camp upkeep (Zapinski, 1994). Lake Butler receives water from Haskell Run, and Lake Litchfield is largely spring-fed from Ritchie Run. Both Haskell Run and Ritchie Run have remained relatively rural and undeveloped during the 20th century (Figures 4 and 5). On Wednesday, August 6, 1981, a tire fire occurred at the Park Tire Company located 
near the headwaters of Haskell Run (Figure 6; Holies, 1981). The tire fire produced 9,000 gallons of tire oil and killed thousands of fish in Haskell Run (Holies, 1981). Barriers were constructed along Haskell Run to limit the tire oil from entering Lake Butler (Masek, 1981). A local witness (Randy Bergdorf) reported the tar from the fire was smoking until at least February 1982, and the director of the Boy Scout camp at the time (Wes Bergdorf) shut down the camp’s drinking water pump until authorities cleaned the site (Henson and Montague, 1981). Other than the tire fire, there were no other major environmental spills or incidents that occurred on Haskell Run or Ritchie Run.

The middle Mud Brook watershed is largely urbanized and contains a dammed impoundment called Old Mill Pond. Old Mill Pond is located in Cuyahoga Falls near the intersection of Bath Road and State Road (Figure 7). To the best of my knowledge, there are no written records to indicate what year Old Mill Pond was dammed. The dam was not present on the 1905 Summit County Topography Map nor the 1910 Summit County Atlas. The dam, however, does appear on the 1936 Summit County Atlas. This indicates the dam was constructed between 1910 and 1936 (The Rectigraph Abstract and Title company, 1910; Sidwell Studio, 1936). ODNR (2016) reports that the concrete dam is approximately $3.1 \mathrm{~m}$ (10 ft) tall, and has a normal pool area of 64,750 $\mathrm{m}^{2}$ (16 acres).

Though Mud Brook watershed was largely rural in the early 20th century, the Mud Brook study area has supported several industries, such as grain, cheese, and lumber factories, since the 19th century (The Rectigraph Abstract and Title company, 1874; Love and Giffels, 1999). The area, formerly located in Northampton Township, was often referred to as the Iron Bridge because of the industry and iron bridges in that area in the late 1800s (Seguin and Seguin, 2000; Bergdorf R., 2016; Hoffman, 2016). The 1910 Summit County Atlas shows that the majority of landowners in the Mud Brook study area were individuals; smaller plots of land can be seen already sectioned off for housing units (Figure 8). 

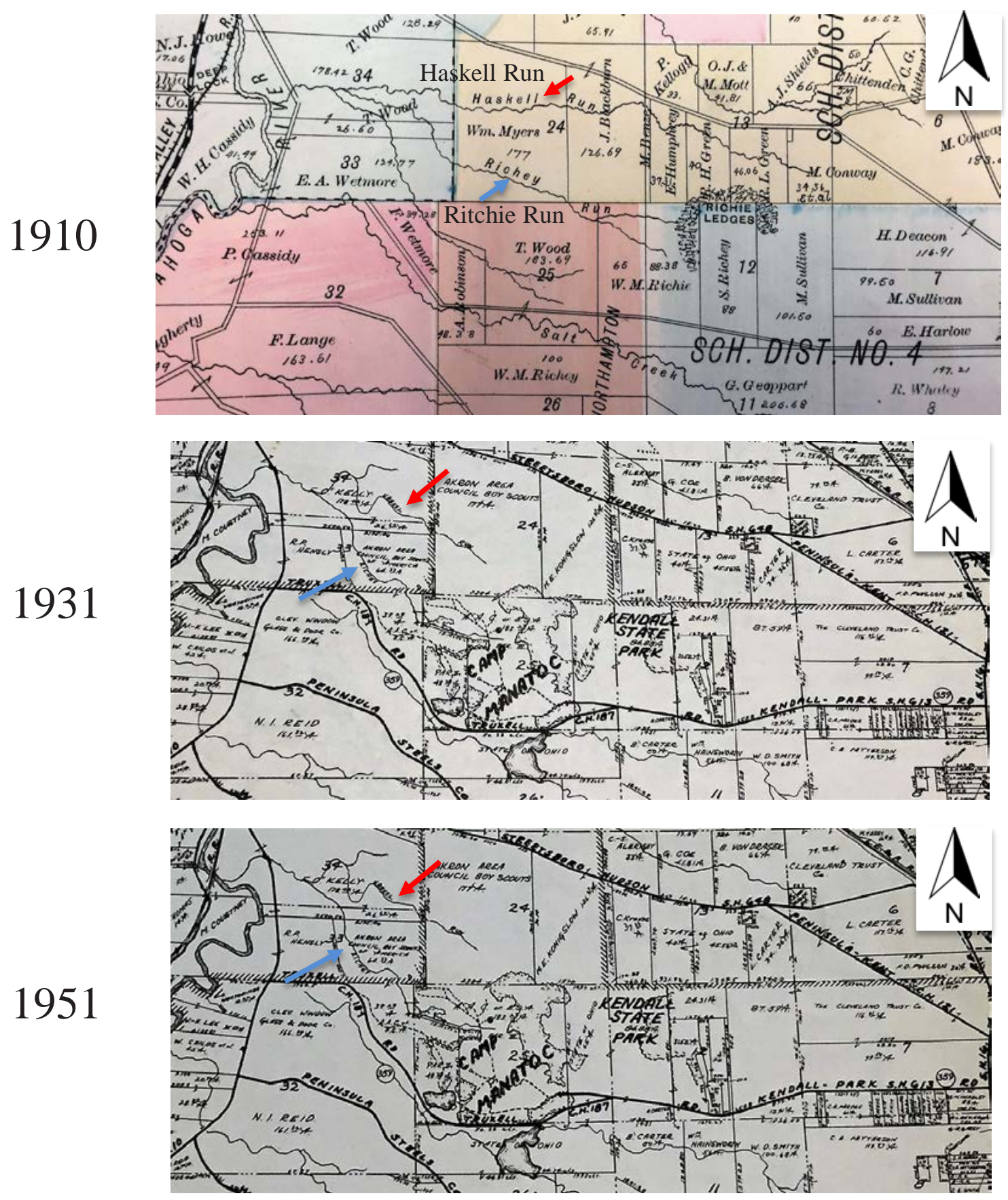

Figure 4. Map of the Haskell Run and Ritchie Run watersheds showing low impact farming or undeveloped land from the Summit County Atlases of 1910, 1936, and 1951 (The Rectigraph Abstract and Title company, 1910; Sidwell Studio 1936; Sidwell Studio 1951). 

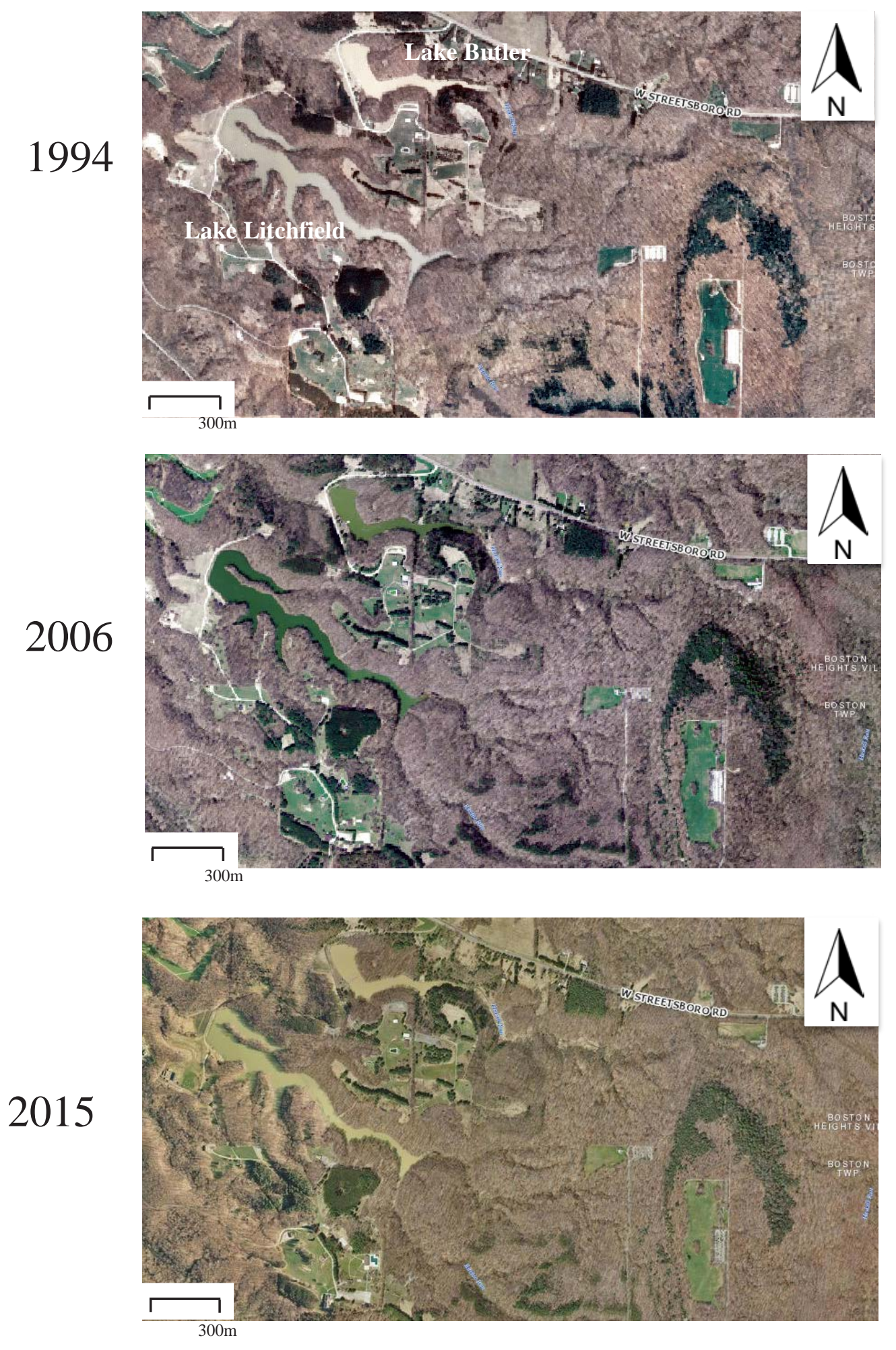

Figure 5. Haskell Run and Ritchie Run in 1994, 2006, and 2015. Haskell Run (Lake Butler) and Ritchie Run (Lake Litchfield), as shown above, have experienced little urban development from 1994 through to 2015 (Summit County Parcel Viewer, 2016). 


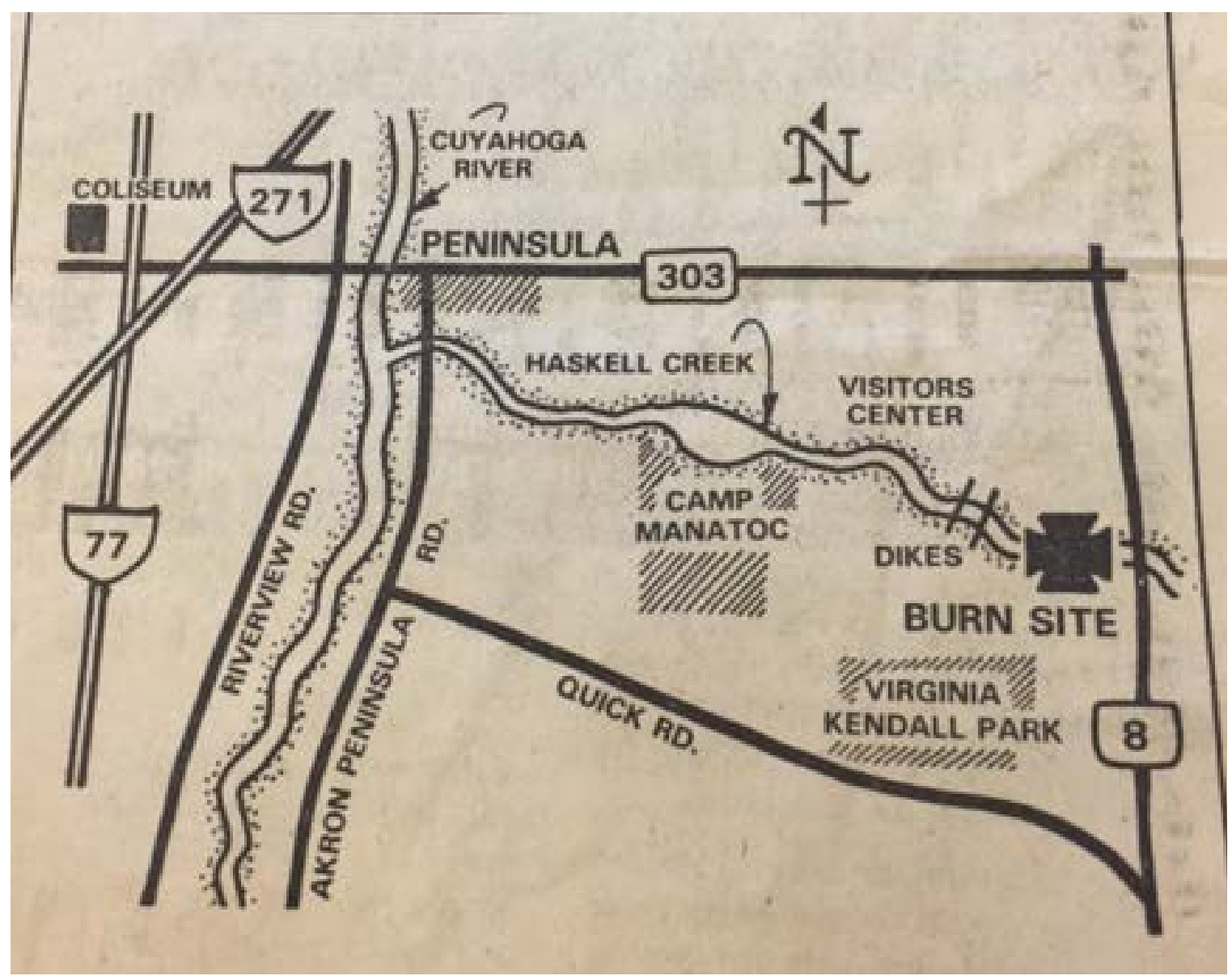

Figure 6. Figure from the newspaper account of the Park Tire Co. tire fire in the Haskell Run watershed on Wednesday, August 6, 1981 (The Cleveland Press, 1981). 


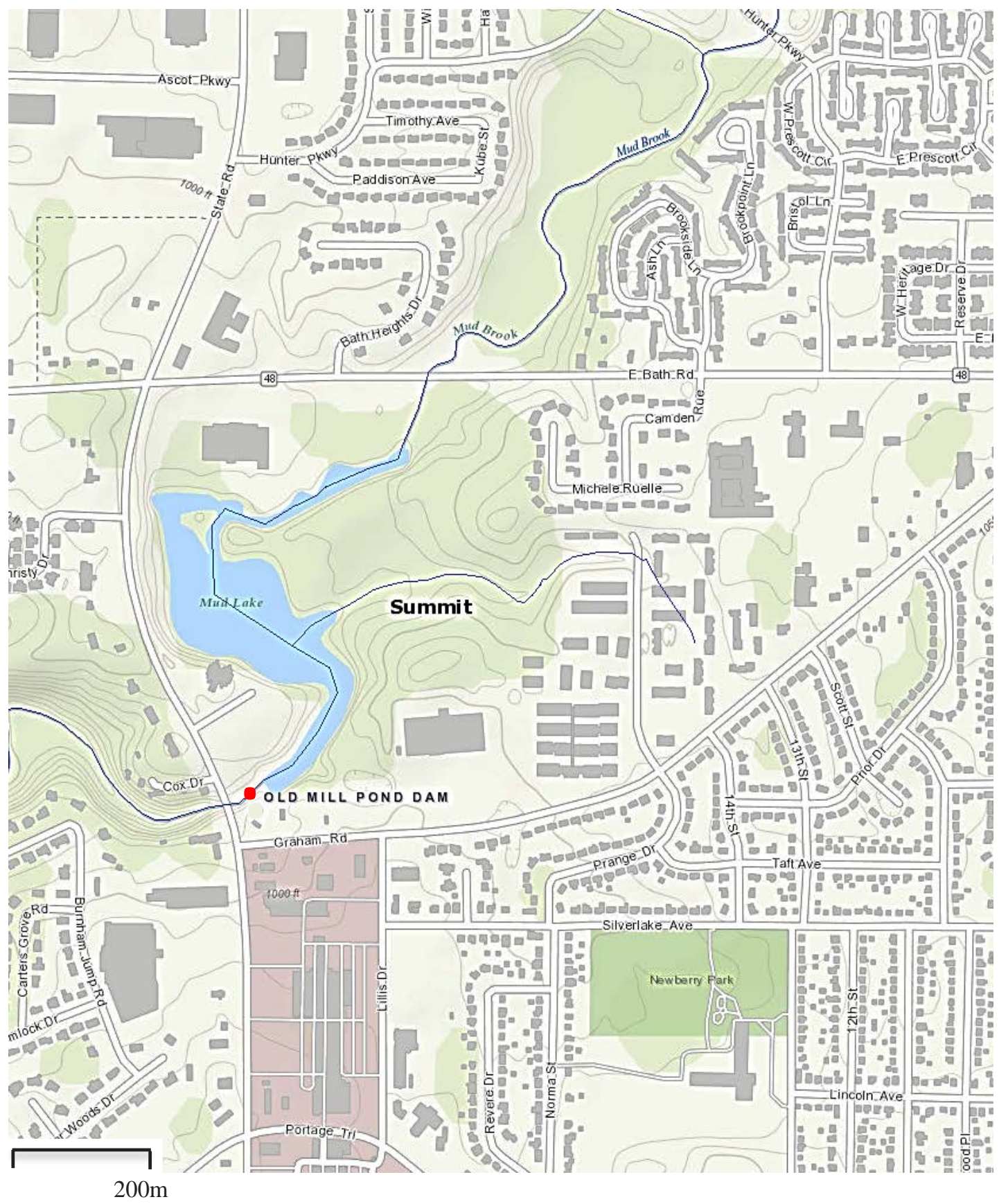

Figure 7. Map showing Old Mill Pond and the surrounding development (ODNR, 2017). 
In the 1910 atlas, the cheese factory and saw mill indicated by the 1874 atlas were no longer present. Some plots of land within the watershed, as indicated on the 1936 Summit County Atlas, were still owned largely by the same individuals; however, more industry, such as Cleveland Downs Inc., is also present between Lake Wyoga and Old Mill Pond. Seguin and Seguin (2000) suggest that a mill at Old Mill Pond was present at least until the late 1930s before a restaurant by the name of Senior's Old Mill Pond was built in the 1940s at the same location (Figure 9). The atlas shows that by 1951 more industry was present in the Mud Brook watershed, and a company called Brook Point IMR Co. owned the land to the northeast, adjacent to Old Mill Pond (Sidwell Studio, 1951). Cuyahoga Falls, around the time following World War II, experienced a doubling in population from approximately 25,000 people in the 1940 s to about 50,000 people in the 1960s (Mann et al., 2013). Since the 1960s, expanding housing developments and industry around Old Mill Pond increased impervious surfaces in the Mud Brook watershed (Figure 10; USGS, 1967; USGS, 1979; Summit County Fiscal Office, 2016). Though there is no boating recreation on Old Mill Pond currently, other recreational activities have occurred within the watershed study site. The former Mud Run Gun Club shooting range was located approximately $1.46 \mathrm{~km}$ upstream of Old Mill Pond. The club ceased operations in the 1990s, and the land is now targeted for environmental remediation of lead contamination from lead ammunition pellets at the site (Wiandt, 2010). As evident from the aerial photos of Old Mill Pond from 1994 to 2015, the housing developments and industry in the Mud Book watershed increased over the last 20 years and is likely to continue increasing into 2017 and 2018 (Figure 11). The home improvement company, Menards, plans to build in 2018 a new retail store adjacent to Old Mill Pond (Figure 11; Schleis, 2015; 2016; 2017). In addition, construction of 77 new condominiums on a 17-acre plot north east of Old Mill Pond has been proposed by Ryan Homes (Schleis, 2015; 2016; 2017). As of June 12, 2016, Google Earth aerial photos indicated that both projects are already underway. 


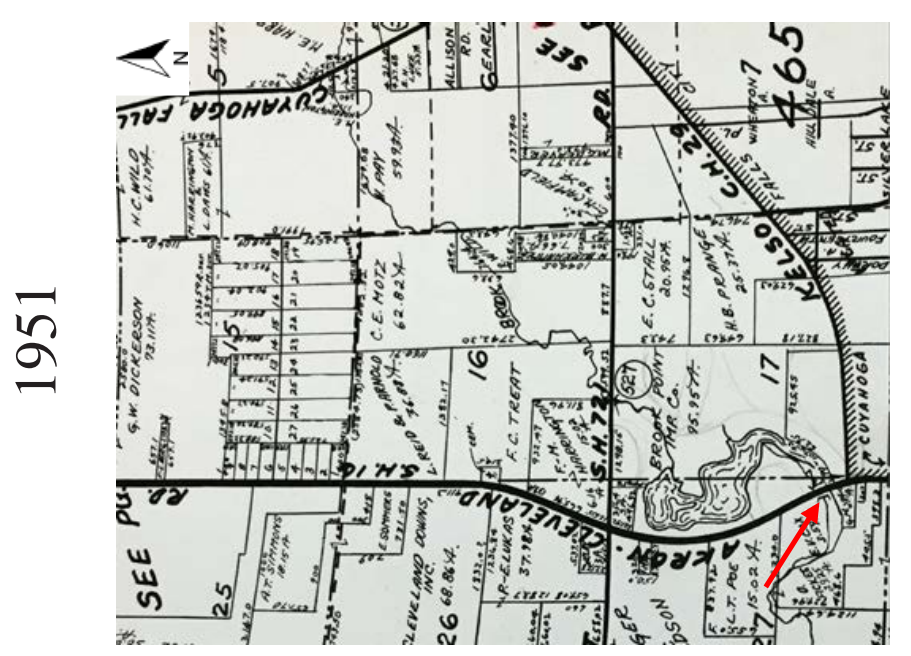

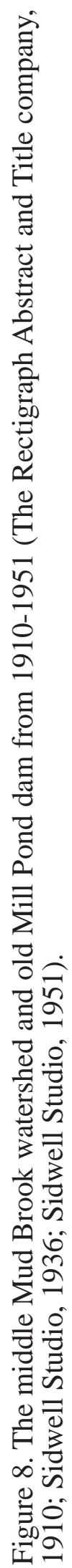



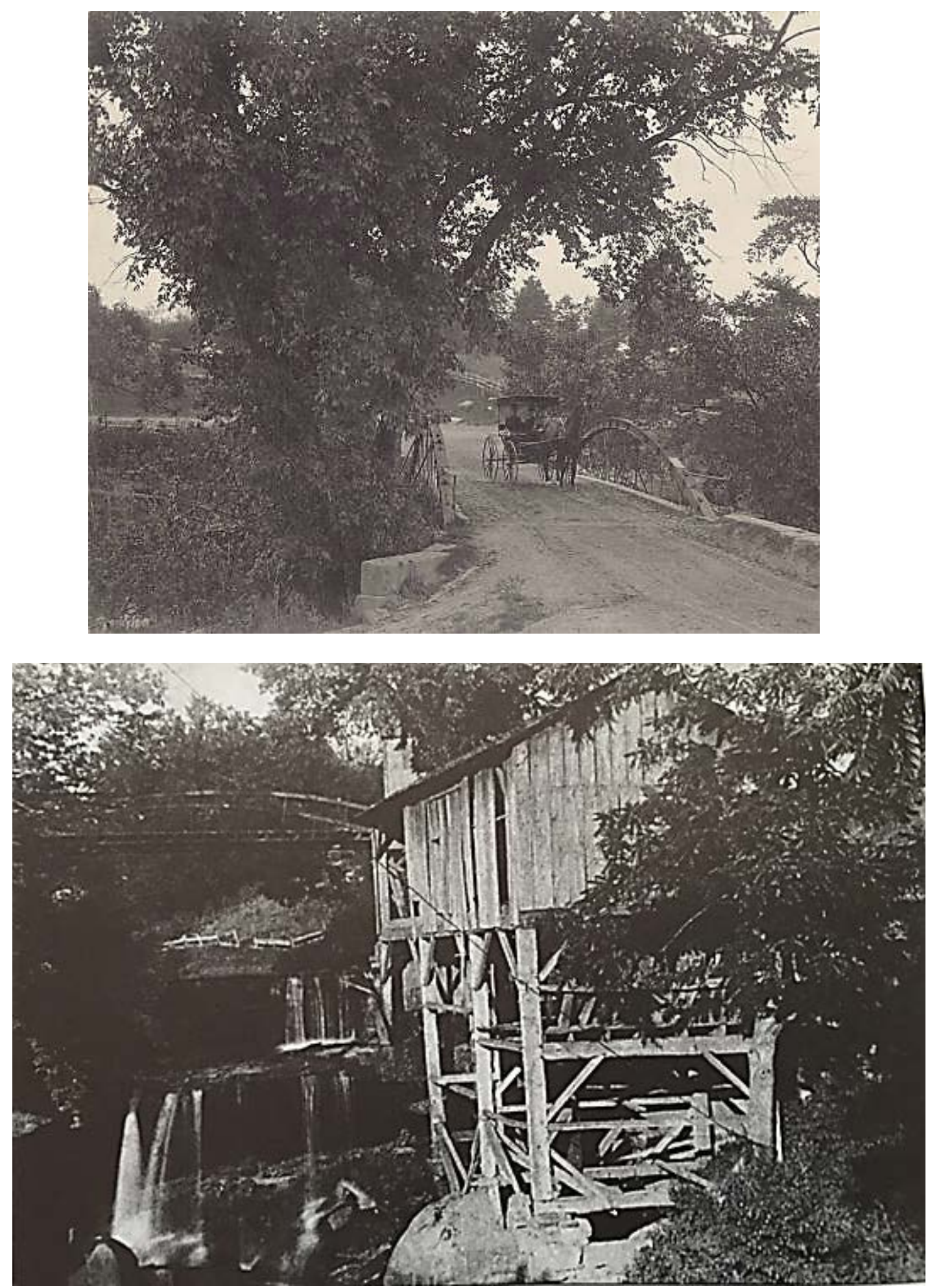

Figure 9. (Top) The "Iron Bridge” in Cuyahoga Falls, picture taken in the late 19th century (SCHS, 2008). (Bottom) A mill formerly on Old Mill Pond by State Rd. The photo was taken before 1940 (Seguin and Seguin, 2000). 


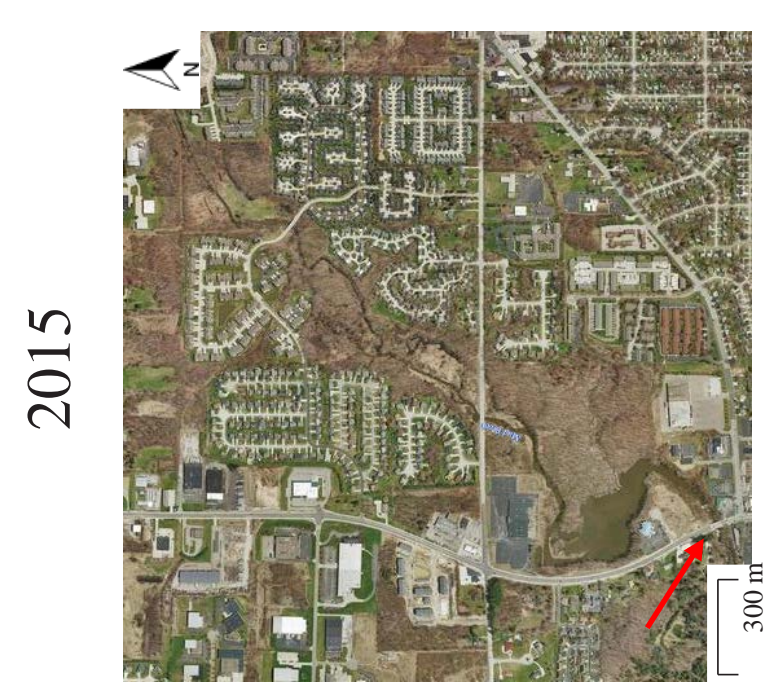

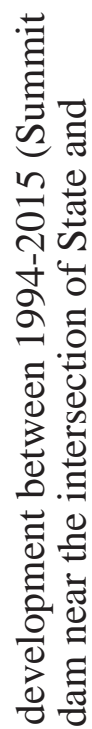

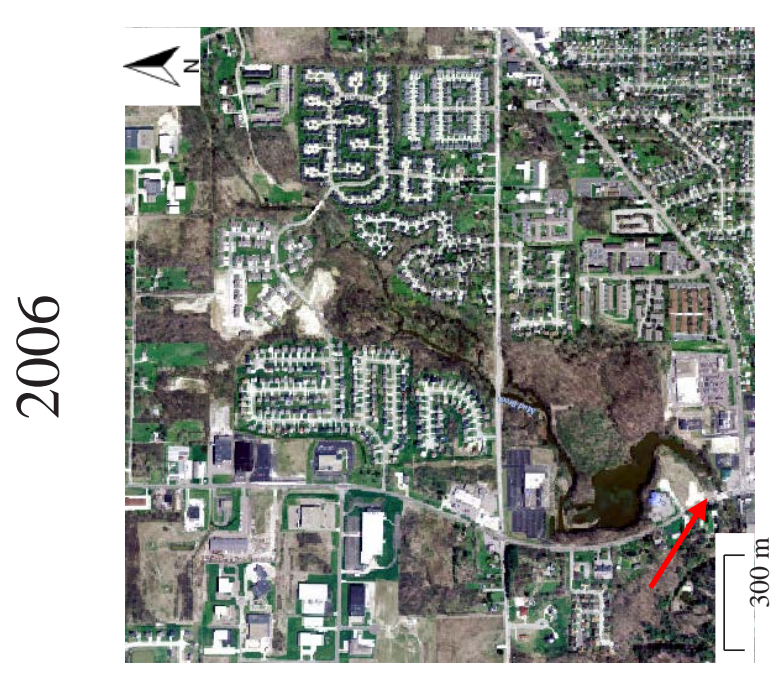

크음

寻灵

임듬

ติ

큼ํㅜ

등 을

ค으

灵孚

등 휸

들.

"ृ

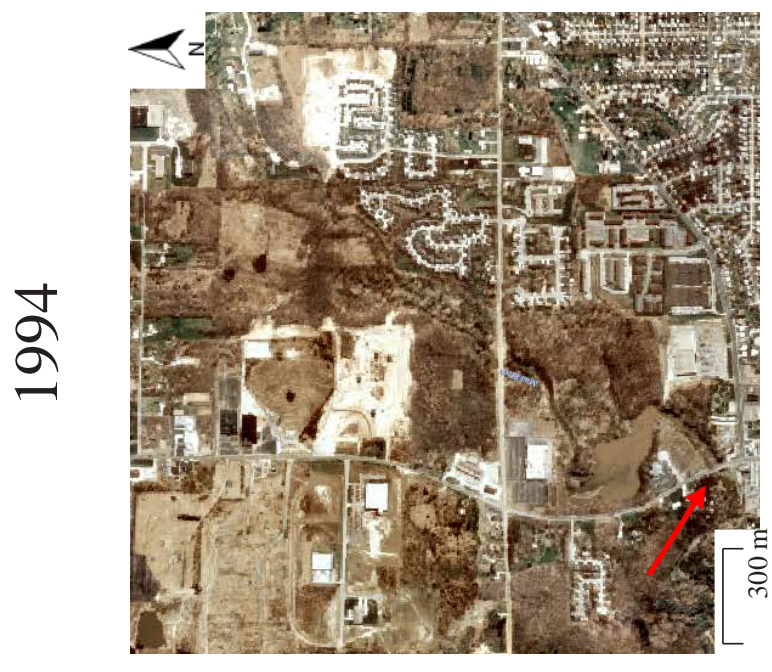

䒕包

농믐

ค

올엉

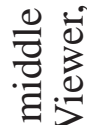

웜

을

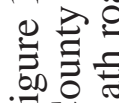

㕸讧 


\subsection{Background}

The geological and anthropogenic histories of the Haskell Run, Ritchie Run, and Mud Brook watersheds were researched to gain an understanding of the changes occurring throughout time in the three study watershed sites.

\subsubsection{Northeast Ohio Geologic Setting}

The bedrock formations in Northeast Ohio are siliciclastic rocks dating back to the Devonian (359 to $407 \mathrm{Ma}$ ), the Mississippian (322 to $359 \mathrm{Ma}$ ), and the Pennsylvanian (302 to $318 \mathrm{Ma}$ ) Periods (Szabo, 1986; Hacker, 2004; ODNR, 2006). The bedrock in the Haskell Run/Ritchie Run and Mud Brook study areas consists of the Pennsylvanian-aged Sharon sandstone, and the Mississippian Cuyahoga Formation contains small amounts of Devonian-age Ohio shale in the incised stream valleys (ODNR, 2006).

During the last glacial maximum, Northeast Ohio experienced glaciations in the late Wisconsinan stage 21,000 to 25,000 year BP (Szabo et al., 2003). In times of glacial retreat, a series of proglacial lakes (Lake Cuyahoga and Lake Independence) formed between the higher topography to the south and the ice to the north (Szabo et al., 2003). Lake Cuyahoga formed before the first advancement of Northampton ice, and Lake Independence formed before the second advancement of Northampton ice (Szabo, 1986). Numerous melt-water streams drained from the upland areas, which created deltas prograding into Lakes Cuyahoga and Independence (Szabo, 1986). The retreating and advancing ice lobes changed the fluvial drainage patterns, causing the ancestral Lake Erie levels to rise and fall (Szabo, 1986; Coakley, 1999; Anderson et al., 2012). About 12,500 year BP, the ice retreated from the Niagara peninsula, draining ancestral Lake Erie (Szabo et al., 2003). The low lake level led to extensive downcutting into the glacial deposits, ultimately shifting the continental divide southward towards present day Akron (Szabo et al., 2003). Post-glacial isostatic rebound of the Niagara Falls area raised Lake Erie’s 


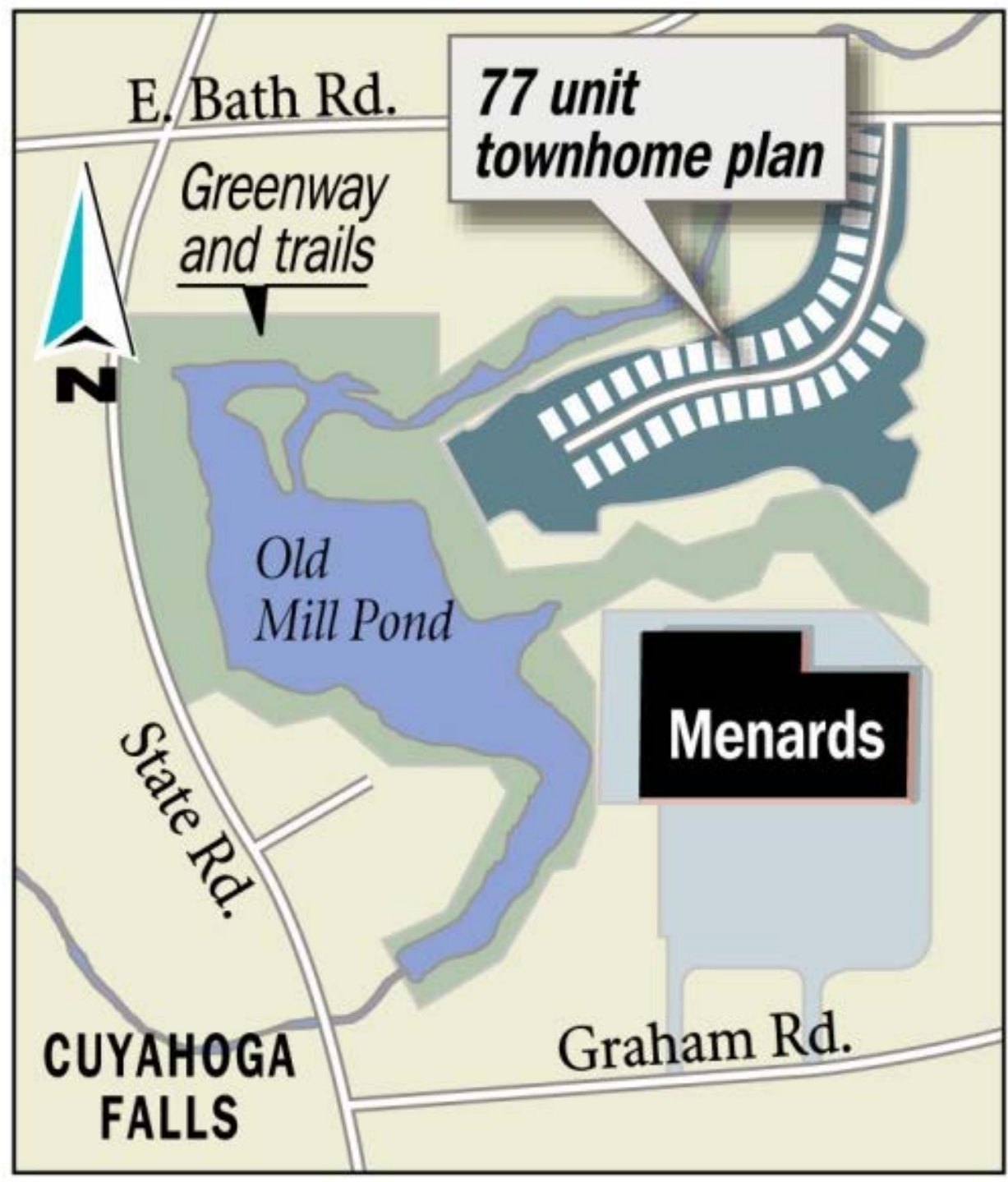

\section{Akron Beacon Journal}

Figure 11. Figure from a news paper article report on the continued development surrounding Old Mill Pond. A 77 unit townhome complex and the hardware store Menards are already underway with construction, and are likely to be completed in 2018 (Schleis, 2015; 2016). 
outlet, thus raising Lake Erie toward modern day lake levels (Coakley, 1999; Szabo et al., 2003; Anderson et al., 2012). In both the upper Haskell Run watershed and the middle Mud Brook watershed, the glacial deposits are largely ridge moraine deposits from the Wisconsinan glaciation 14,000 to 24,000 year BP (ODNR, 2005).

\subsubsection{Northeast Ohio Anthropogenic Past}

The Cuyahoga River Valley served as an important transportation route for native tribes, European traders, and explorers portaging between Lake Erie and the Tuscarawas River in the 17th century (Hacker, 2004). The European-American settlers came to Northeast Ohio beginning around 1800 Common Era (CE), ultimately transforming regional ecosystems, sediment yield, and fluvial patterns (Webb-Sullivan and Evans, 2014; Church and Ferguson, 2015). Wolman (1967) provides a conceptual model depicting the impact of land cover changes on sediment yield. The model suggests that around 1800 CE, much of the land cover in the eastern United States was forested and channel conditions were stable (Figure 12). During the 19th century, forests were clear-cut for agricultural purposes, resulting in increased sediment yield and channel aggradation. As farm fields reverted to secondary growth in the 20th century, sediment yield declined. In the 1960s, a surge of construction, such as highway building and suburban development, resulted in a spike in sediment yield and channel aggradation. With urbanized watersheds, sediment yield declines as sediment sources are covered, and channels are scoured and banks are eroded from the increased runoff from an urban watershed (Wolman, 1967; Church and Ferguson, 2015).

In 1827, the Ohio and Erie Canal was opened from Akron to Cleveland and brought industry, trade, and the beginnings of manufacturing to the Cuyahoga River Valley (Hacker, 2004). In the 1850s, Northeast Ohio began to transition to railroads, and canals became obsolete. The rubber industry in Akron began circa 1870s and lasted for about 


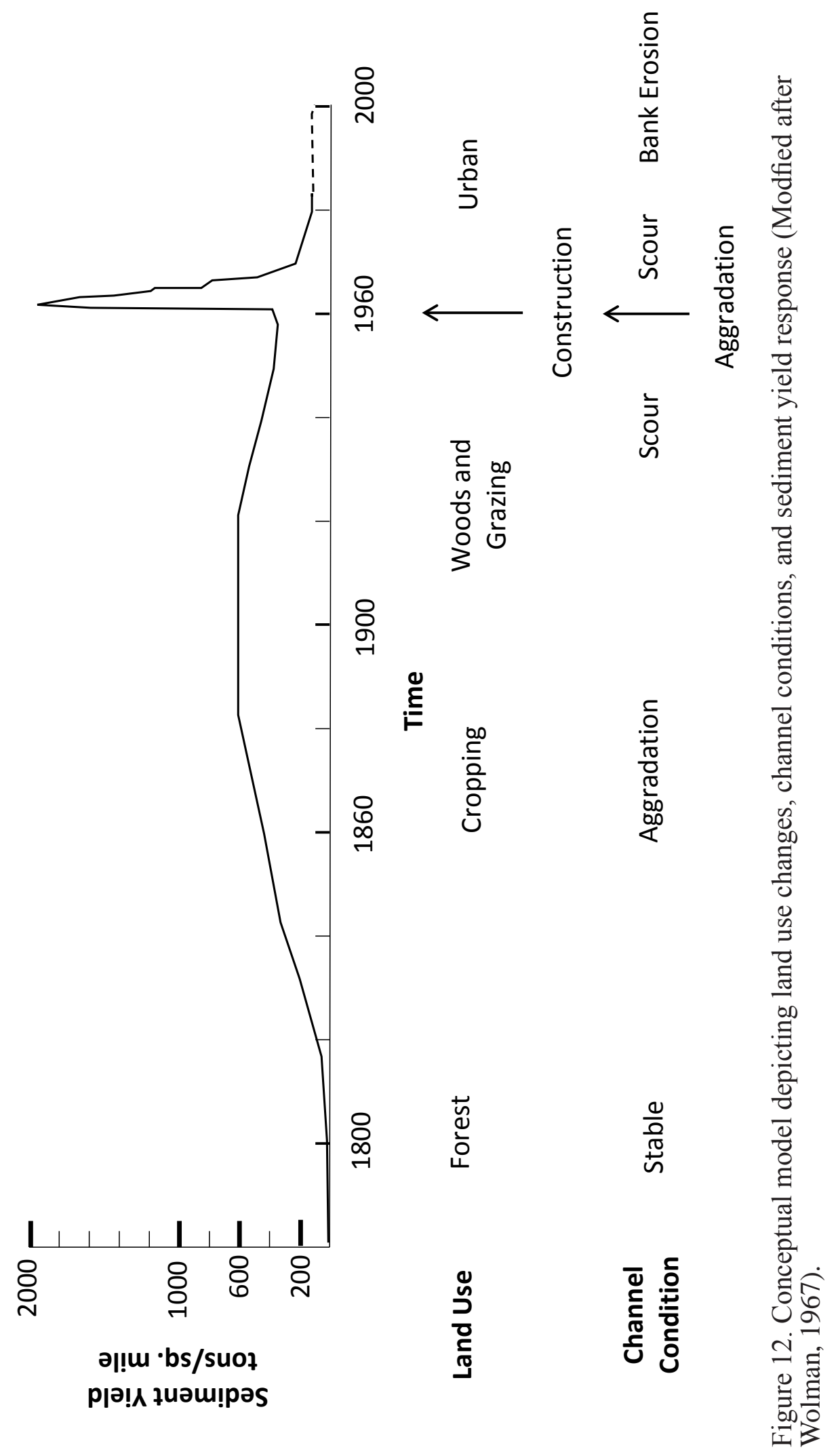


100 years until it experienced a significant decline in the 1980s (Love and Giffels, 1999). The pollution from industrial expansion in the Akron area stressed the local waterways and ecosystems (Haney, 2004; Yuan et al., 2013).

Currently, the Akron-Cleveland metropolitan area has a population of around 2 million people (Yuan et al., 2013). Approximately 15\% of that population live in the Cuyahoga River Valley (Hacker, 2004). The legacy sediment (LS) in waterways has become a subject of concern for scientists and environmentalists. LS is commonly understood to be sourced from high sediment input during episodic events rather than cumulative century-long anthropogenic sedimentation (Wohl, 2013; James, 2013; Webb-Sullivan and Evans, 2014; Wohl, 2015). Additionally, LS is defined as being composed mostly of alluvial and colluvial sediments sourced from terrigenous and fluvial environments that yield a significantly high sedimentation rate in the depositional record (James, 2013). The geomorphic and sedimentary distinction of LS and normal sediment loading equates to sediment delivery that exceeds sediment transport in the fluvial environment (James, 2013).

On December 27, 1974, the Cuyahoga Valley National Recreation Area, now Cuyahoga Valley National Park, the nation's third urban national park, was established, becoming Cuyahoga Valley National Park in 2000 (Harnapp, 1988; Mason, 1994; Hamin, 2001; Hacker, 2004). Mason (1994) suggests that the creation of Cuyahoga Valley National park and other similar parks in metropolitan areas in the 1970s was a national response by Congress to rising environmentalism in the United States. These parks provided recreation and green-space in highly urbanized areas such as the AkronCleveland region. In addition, the parks aided in preserving ecosystems threatened by urban sprawl. All three thesis study watershed sites ultimately drain into the national park and the Cuyahoga River. 


\subsubsection{Climate Change in Northeast Ohio}

Developed land cover around the Akron area has induced an increase in fluvial energy from more impervious surfaces; however, climate change also plays a role in dictating local fluvial conditions. In the Akron-Canton area, the mean average temperature is approximately $49.8^{\circ} \mathrm{F}\left(\sim 10^{\circ} \mathrm{C}\right)$, with July on average the warmest month at $72^{\circ} \mathrm{F}$ $\left(\sim 22^{\circ} \mathrm{C}\right)$ and January the coldest at $26.1^{\circ} \mathrm{F}\left(\sim-3^{\circ} \mathrm{C}\right)$ (NOAA, 2016b). The total average precipitation rate is approximately $39.62 \mathrm{in} / \mathrm{yr}(\sim 100 \mathrm{~cm} / \mathrm{yr})$ and the average snowfall, factored into the total precipitation, is $47.5 \mathrm{in} / \mathrm{yr}(\sim 120 \mathrm{~cm} / \mathrm{yr})$, or about $5 \mathrm{in} / \mathrm{yr}(12.7 \mathrm{~cm} /$ yr) of precipitation (NOAA, 2016b). Climate conditions in Northeast Ohio, however, are deviating from these long-term averages.

In Northeast Ohio and elsewhere globally, the frequency and magnitude of storms and floods are increasing (Pielke, 2005; Liberatore, 2013; Mann et al., 2013; Schillereff et al., 2014; Delaney, 2016). After July 2003, flooding has increased in Northeast Ohio (Liberatore, 2013). Four of the top ten wettest years in Akron from 1880-2016 occurred after July 2003: 2014, 2011, 2004, and 2003 (Table 1; Liberatore, 2013; NOAA, 2016b). Seven of the top ten flood events at Old Portage Path on the Cuyahoga River also occurred after July 2003 (Table 1; NOAA, 2016a). The USGS gage station records for the Cuyahoga River at Old Portage Path show more high-flow days over the past 13 years (2003 to 2016) than any other 13 year period in the last 95 years (Table 2; Figure 18). A mean daily discharge value of 80 cubic meters per second (cms) was selected to represent high-flow events (Liberatore, 2013). From July 2003 to February 2016, there have been 67 high-flow days, whereas other 13 year periods only have between 11 and 21 high-flow days (Table 2; Figure 13; USGS, 2016). The contiguous United States is warming, with 2015 being the warmest year on record within the last 135 years (NOAA, 2016c). From 1950 to 2009, 65\% of record daily high temperatures occurred between 2000 and 2009 
Table 1. Top ten historic crests of the Cuyahoga River (NOAA, 2016a) and wettest years in Akron, OH (NOAA, 2016b).

\begin{tabular}{ccc}
\hline \multicolumn{3}{c}{ Historic Crests of the Cuyahoga River at Old Portage } \\
\hline \hline Rank & Year & $\begin{array}{c}\text { Height } \\
\text { (m) }\end{array}$ \\
\hline \hline 1 & 2013 & 4.4 \\
2 & 2004 & 4.2 \\
3 & 1979 & 4.1 \\
4 & 2011 & 4.0 \\
5 & 2014 & 3.9 \\
6 & 2003 & 3.9 \\
7 & 1976 & 3.7 \\
8 & 2011 & 3.5 \\
9 & 1959 & 3.5 \\
10 & 2005 & 3.4 \\
\hline
\end{tabular}

\begin{tabular}{ccc}
\hline \multicolumn{3}{c}{ Wettest Years 1900-2015 } \\
\hline \hline Rank & Year & $\begin{array}{c}\text { Amount } \\
\text { (cm/yr) }\end{array}$ \\
\hline \hline 1 & 1990 & 166.9 \\
2 & 2011 & 148.3 \\
3 & 2003 & 129.8 \\
4 & 1956 & 119.5 \\
5 & 1926 & 119.4 \\
6 & 1996 & 119.2 \\
7 & 2004 & 117.6 \\
8 & 2014 & 116.1 \\
9 & 2000 & 115.6 \\
10 & 1913 & 115.4 \\
\hline
\end{tabular}


Table 2. Number of high flow events on the Cuyahoga River at Old Portage Path, Ohio in 13-year intervals since 1921(USGS, 2016a).

\begin{tabular}{cc}
\hline $\begin{array}{c}\text { Years } \\
(\sim 13 \text { year periods })\end{array}$ & $\begin{array}{c}\text { Days Over } \\
80 \mathrm{cms}\end{array}$ \\
\hline \hline $2 / 2016-7 / 2003$ & 67 \\
$7 / 2003-7 / 1990$ & 11 \\
$7 / 1990-7 / 1977$ & 19 \\
$7 / 1977-7 / 1964$ & 11 \\
$7 / 1964-7 / 1951$ & 21 \\
$7 / 1951-7 / 1938^{*}$ & 10 \\
$7 / 1938-10 / 1921^{*}$ & 21 \\
\hline
\end{tabular}

* Missing data from 1/1936-2/1939 


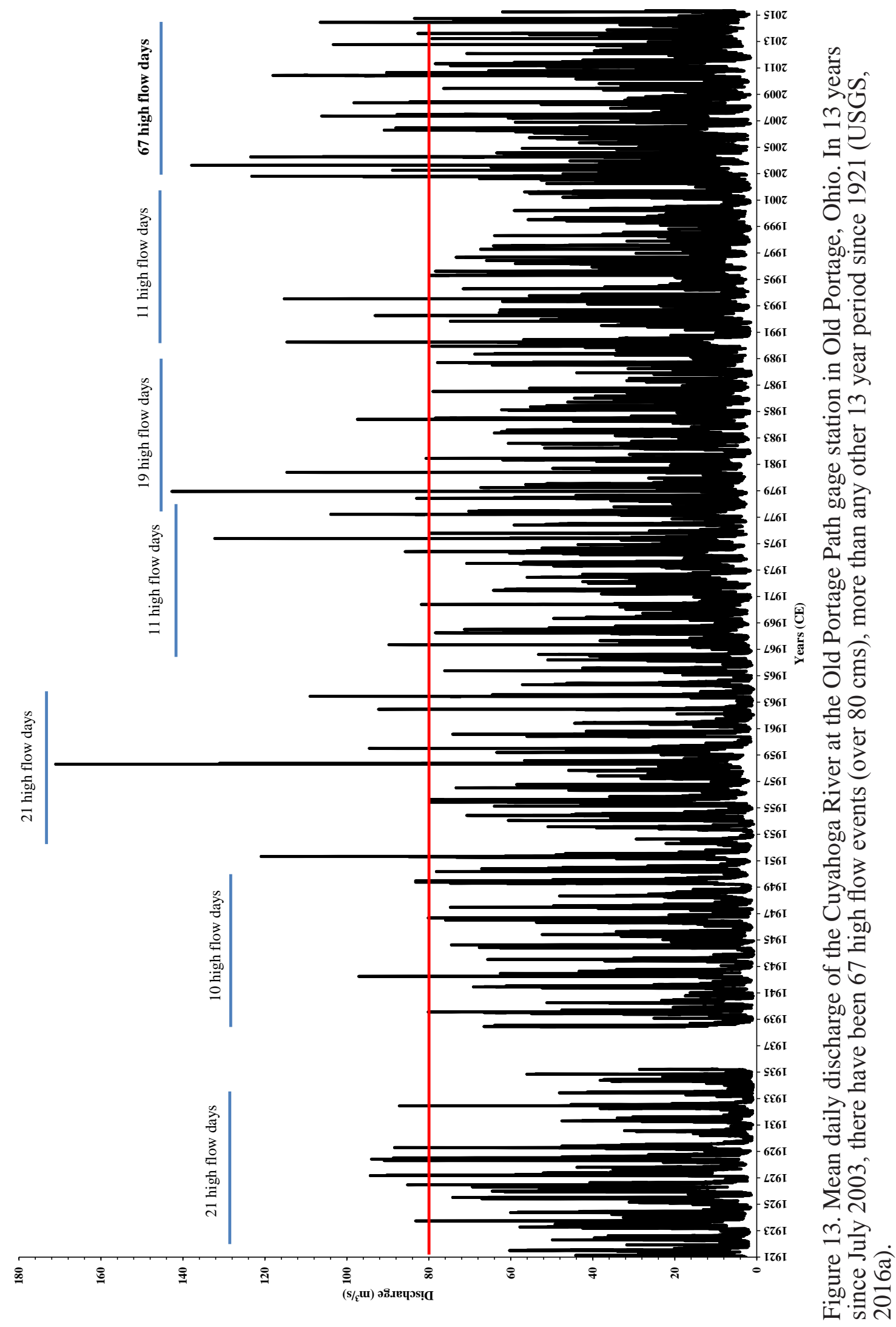


(U.S. EPA, 2014). As air temperature increases, more frequent and intense precipitation and flood events are expected as the hydrological cycle accelerates (U.S. EPA, 2014). 


\section{CHAPTER II}

\section{METHODS}

Surface sediment samples and sediment cores were collected for this thesis study at the three impoundment sites: Lake Butler, Lake Litchfield, and Old Mill Pond. Discharge and total suspended sediment data were collected at Lake Butler. Sediment samples were analyzed in the lab for sediment properties, magnetic properties, and heavy metals. Watershed land cover change was processed and analyzed in the computer lab using ArcMap.

\subsection{Field Methods}

A total of 15 sediment cores and 40 surficial sediment samples were collected from Lakes Butler and Litchfield, and Old Mill Pond in March and May of 2016. The trapping efficiency and stream discharge of Lake Butler was measured in March and November of 2016.

\subsubsection{Sediment Core Sampling}

A modified Livingston piston corer was used to collect sediment cores from Lake Butler, Lake Litchfield, and Old Mill Pond (Figures 14-16; Tables 3-5). A Wildco grab sampler was used to collect two short surface cores from Old Mill Pond. The delta environments where streams entered each impoundment were selected for coring. Latitude and longitude of each core location was determined with a Garmin global positioning system (GPS). 


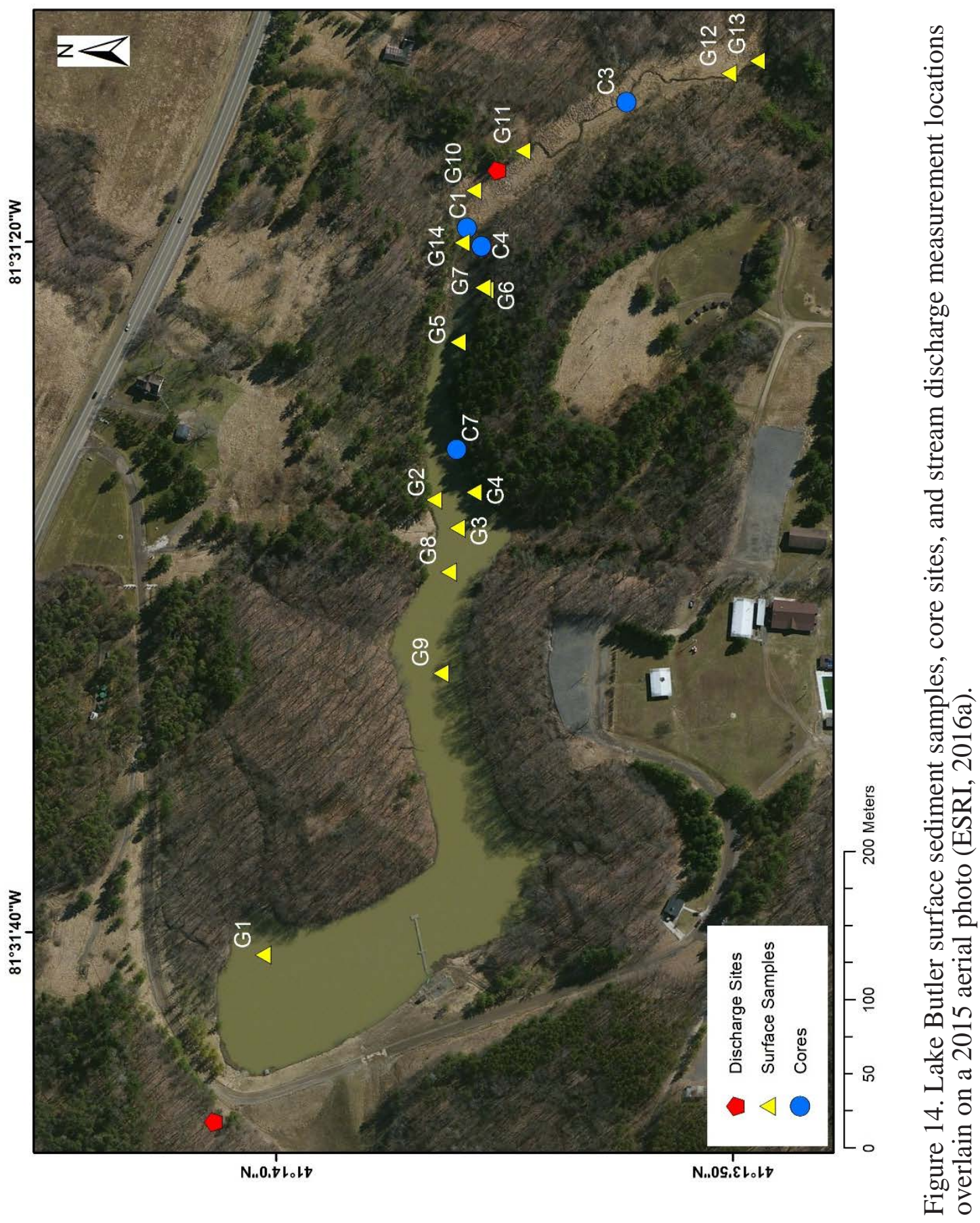




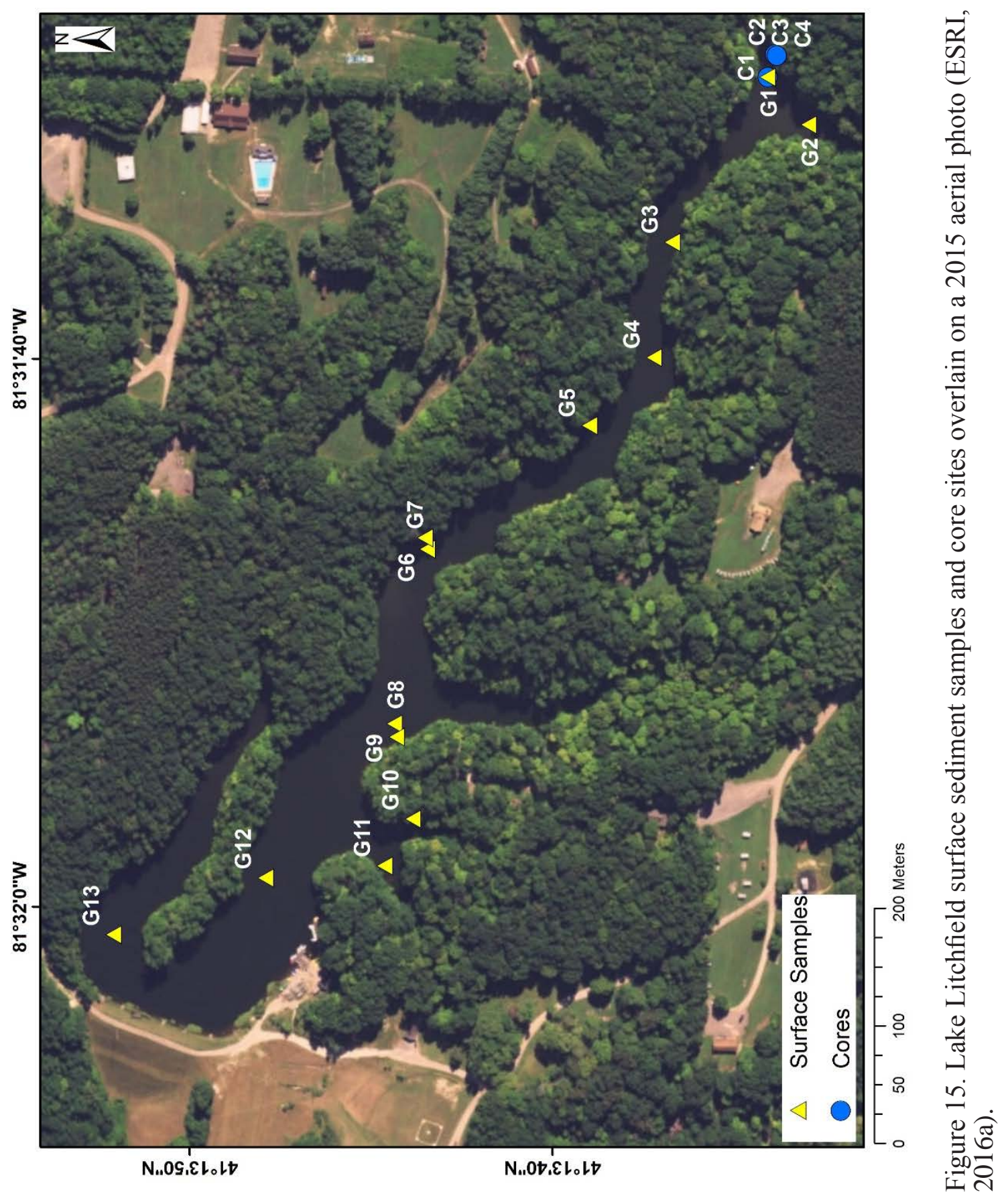




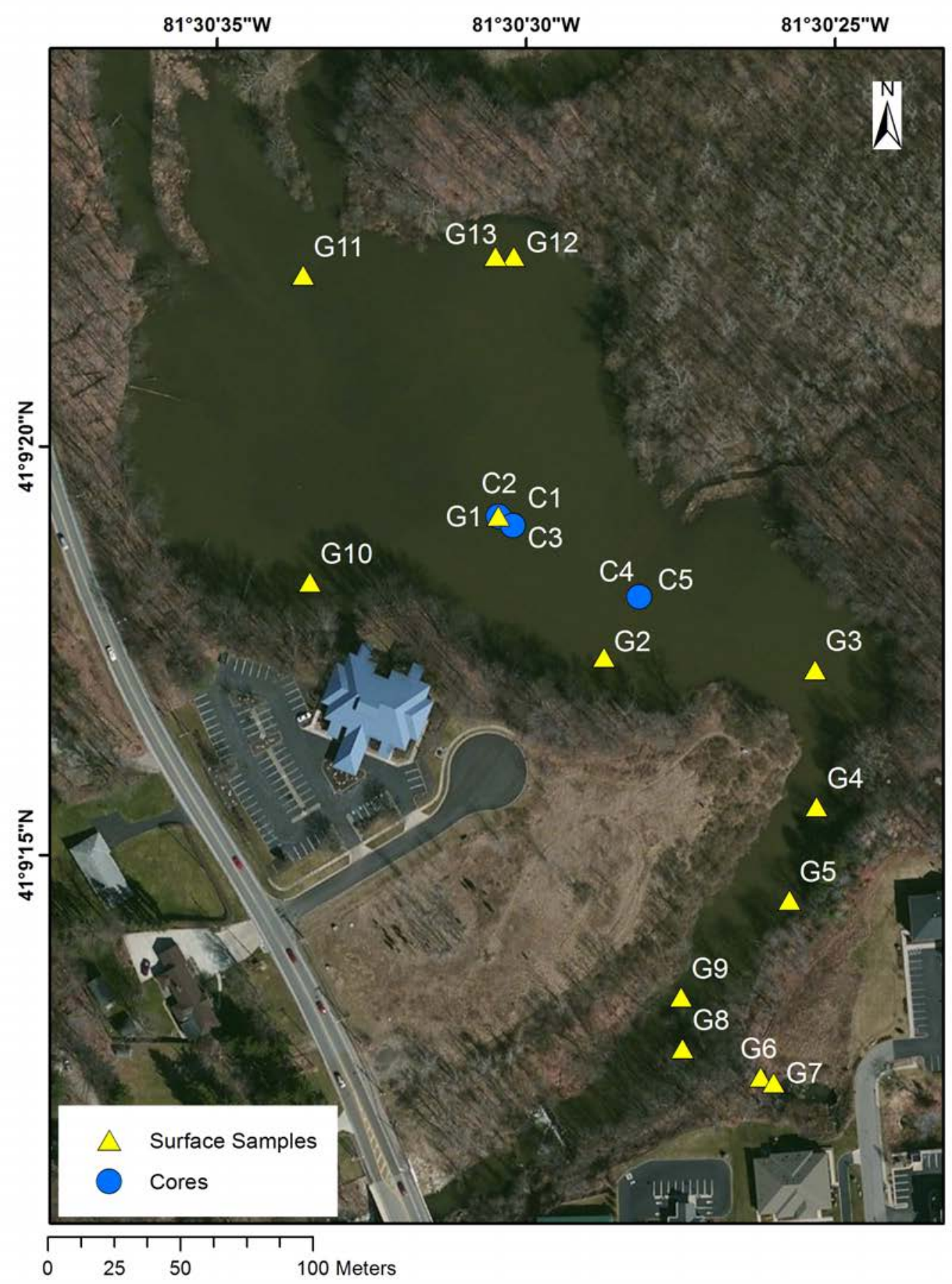

Figure 16. Old Mill Pond surface sediment samples and core sites overlain on a 2015 aerial photo (ESRI, 2016a). 


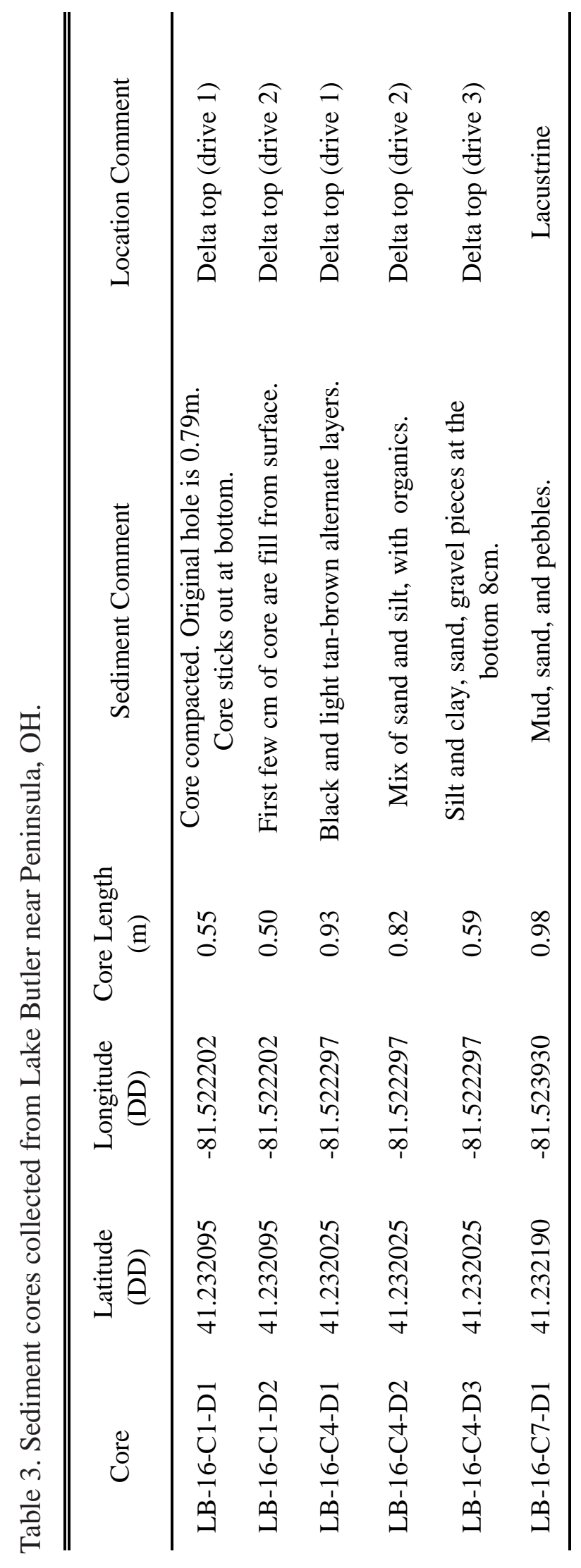




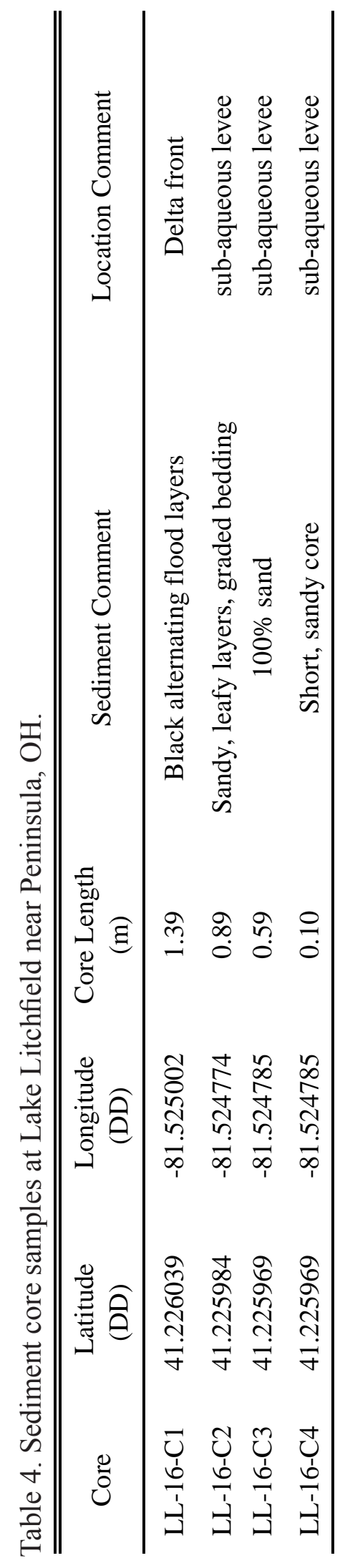




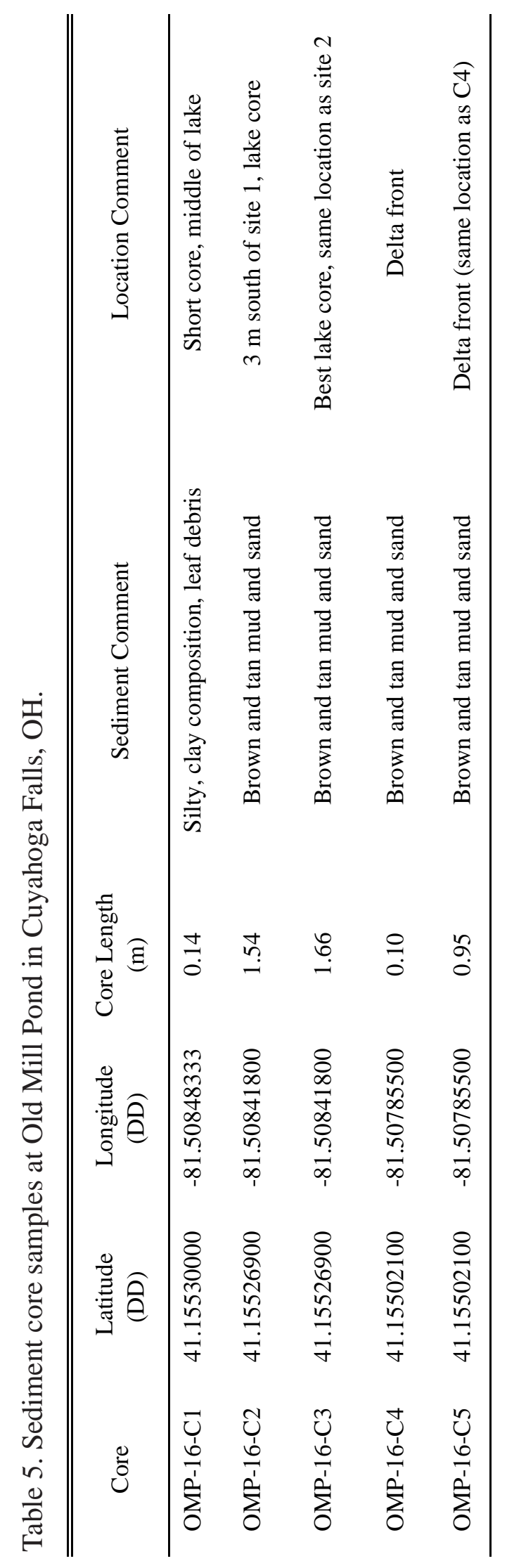




\subsubsection{Surface Sediment Sampling}

A total of 13 to14 surface sediment samples were collected from each lake with a Wildco grab sampler or a pole-mounted scoop (Figures 14-16; Tables 6-8). Latitude and longitude of each sample location was determined with a Garmin GPS. The water depth at each site was measured with a grab sampler rope, which was marked in 1 meter increments. Surficial sediment samples were located near core sites and longitudinally down the impoundment.

\subsubsection{Trapping Efficiency and Stream Discharge of Lake Butler}

On March 25 and November 21, 2016, the sediment trapping efficiency of Lake Butler was estimated by measuring the inflow and outflow discharge (Table 9). The inflow and outflow water discharge was measured with a Gurley Pygmy flow meter and meter stick. Total suspended sediment (TSS) concentrations were measured with the Ohio Sediment Stick (ODNR, 2014). Inflow measurements were made in Haskell Run near where it joins Lake Butler. Outflow measurements were made in the outflow culvert at the base of the dam. Suspended sediment discharge (Qs) was determined by multiplying the water discharge $(\mathrm{Qw})$ at a particular location by the average suspended sediment concentration.

\subsection{Lab Methods and Equipment}

All sediment samples from Lake Butler, Lake Litchfield, and Old Mill Pond were processed in the laboratory. The samples were measured for magnetic properties, heavy metals, and physical sediment properties. 


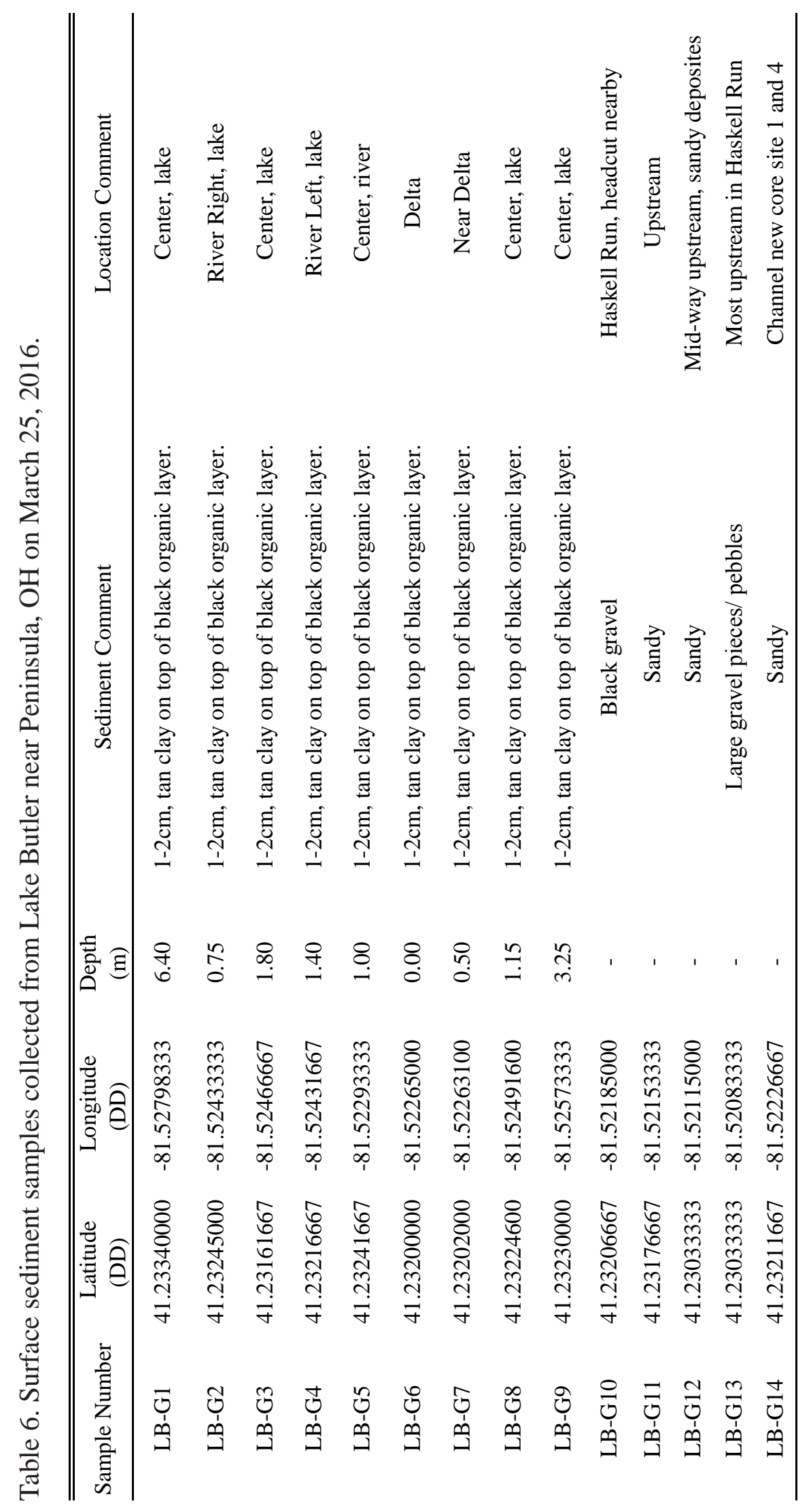




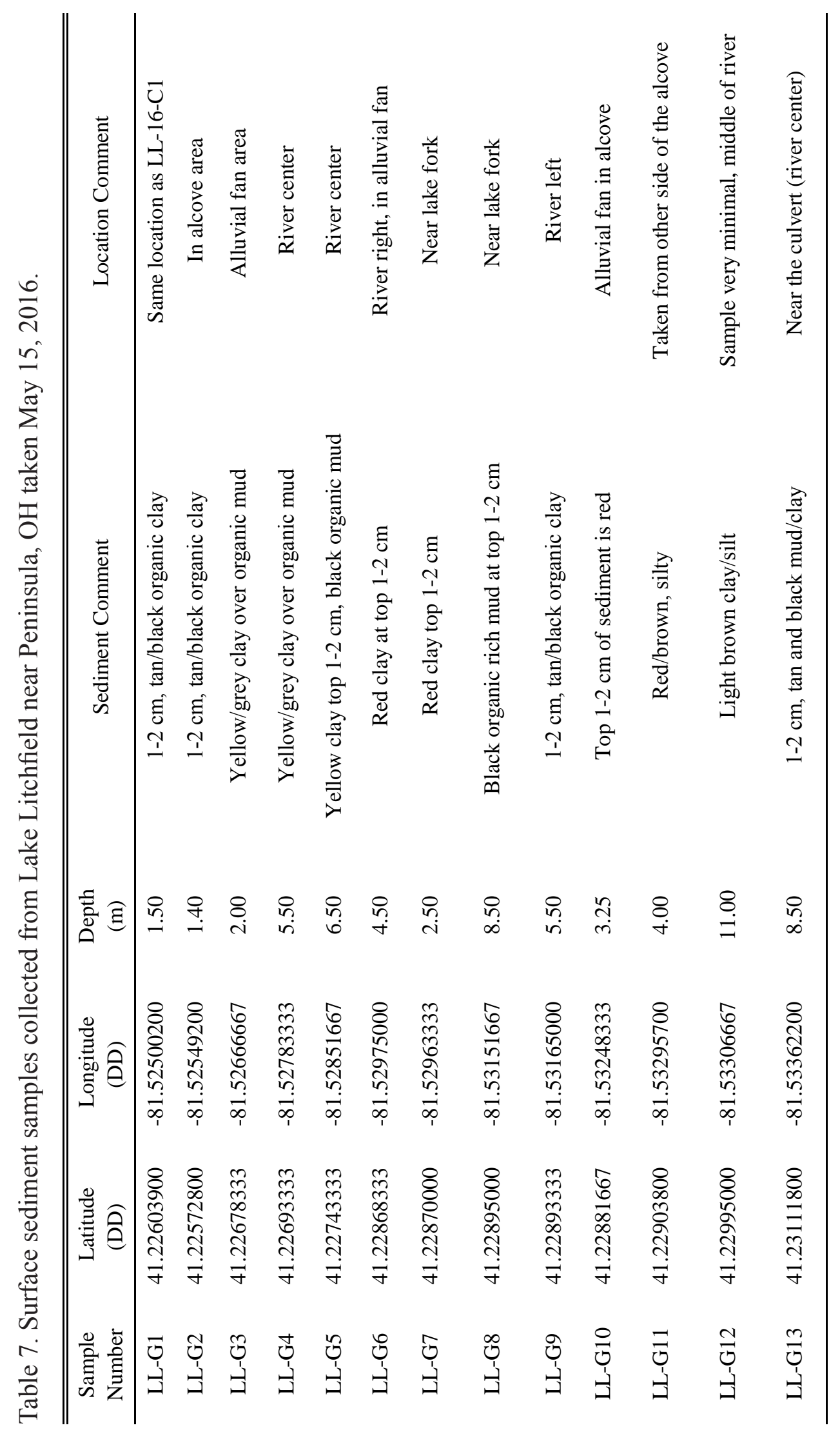




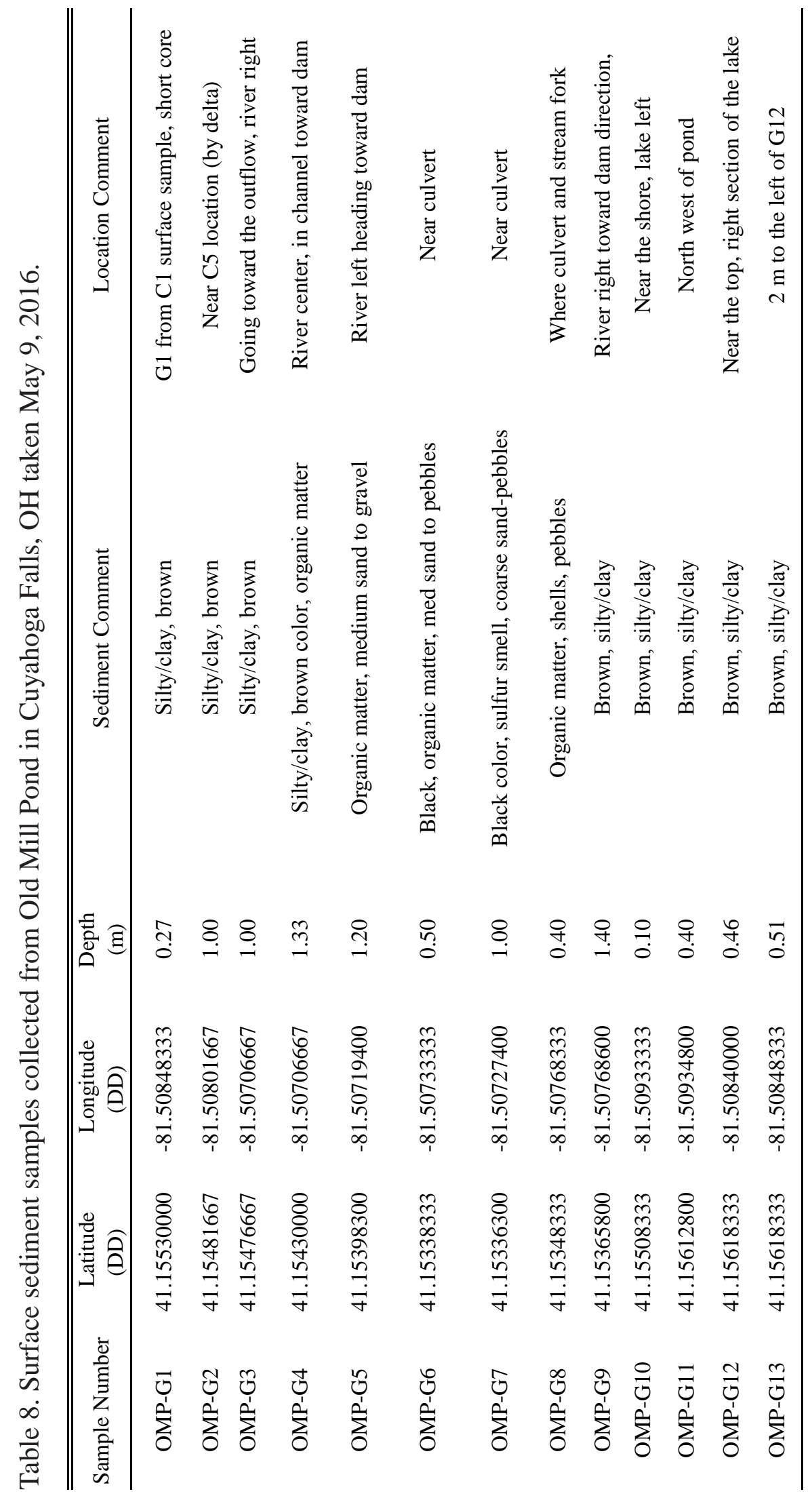


Table 9. Lake Butler inflow and outflow discharge measurement locations.

\begin{tabular}{cccc}
\hline \hline Date & $\begin{array}{c}\text { Latitude } \\
\text { (DD) }\end{array}$ & $\begin{array}{c}\text { Longitude } \\
\text { (DD) }\end{array}$ & $\begin{array}{c}\text { Location } \\
\text { Comment }\end{array}$ \\
\hline $3 / 25 / 2016$ & 41.23213 & -81.521984 & Inflow \\
$3 / 25 / 2016$ & 41.233108 & -81.530014 & Outflow \\
$11 / 21 / 2016$ & 41.231975 & -81.521749 & Inflow \\
$11 / 21 / 2016$ & 41.233108 & -81.530014 & Outflow \\
\hline
\end{tabular}




\subsubsection{Magnetic Susceptibility ( $\kappa)$}

All sediment cores were measured for whole-core magnetic susceptibility $(\kappa)$ at a $3 \mathrm{~cm}$ interval using a Bartington MS2C core logging sensor. Whole-core magnetic susceptibly $(\kappa)$ is based on sample volume and is a measure of the concentration of ferrimagnetic material within a sample that is placed in a magnetic field (Evans and Heller, 2003). $\kappa$ is measured in a field; therefore, a significant amount of diamagnetic and paramagnetic material can influence the measurement (Evans and Heller, 2003).

\subsubsection{Lithology Analysis}

The cores were spilt length-wise and visually described for grain size, composition, color, and sedimentary structures. The cores were then photographed. Half of each core was subsampled for further laboratory analysis. The other core halves were archived in the sedimentology refrigerator. To further identify sediment components, smear slides were made of the various lithologies from all three lakes. The slides were analyzed using a petrographic microscope.

\subsubsection{Loss-On-Ignition}

All surface samples and all cores, sampled at $1 \mathrm{~cm}$ intervals, were measured for loss-on-ignition (LOI) using the Dean (1974) method. LOI was used for measuring bulk density (dry or wet weight of sediment per unit volume) and organic matter content. 1 cubic centimeter (cc) of wet sediment was dried in the muffle furnace at $100^{\circ} \mathrm{C}$ for 24 hours. Samples were then burned at $550^{\circ} \mathrm{C}$ for 2 hours. The contents were weighed before drying, after drying, and after burning to calculate weight loss. 


\subsubsection{Grain Size Analysis}

The Folk (1980) pipette method was used to measure grain size on representative mud samples from selected surface samples and cores. Approximately $30 \mathrm{~g}$ of wet mud was treated with $10 \mathrm{~mL}$ of $30 \%$ hydrogen peroxide twice a day for six days to oxidize organic matter. It is likely that not all the organic matter was eliminated from the sediment. All samples were then air-dried and weighed. The sediment was combined with $250 \mathrm{~mL}$ of sodium metaphosphate $\left(\mathrm{PO}_{4}\right)$ solution for 24 hours to prevent flocculation. Prepared samples were then added to a $1000 \mathrm{~mL}$ graduated cylinder and the water level was raised to $1000 \mathrm{~mL}$ using deionized water. The samples were well mixed and a timer was started when the stir bar broke the water surface. $20 \mathrm{~mL}$ aliquots were pipetted into pre-weighed jars at particular time intervals and cylinder depths to determine the mud grain size distribution (Table 10). After pipetting, the samples were wet sieved at $4 \Phi(0.0625 \mathrm{~mm})$ to determine the percent sand and gravel. The grain size fractions in the jars were dried at $80^{\circ} \mathrm{C}$ for three days, cooled, and weighed.

Sand and gravel samples were sieved using a Tyler Rotap and following the methods of Folk (1980). Samples were sieved from -3Ф $(8.0 \mathrm{~mm})$ to $4 \Phi(0.0625 \mathrm{~mm})$ in $0.5 \Phi$ increments to determine the grain size distribution. The very coarse sands $(0 \Phi)$ were analyzed under a binocular microscope to determine the relative percent of anthropogenic particles to naturally occurring sand particles.

\subsubsection{Magnetic Analysis}

All surface samples and representative down core lithologies were measured for magnetic concentration, grain size, and minerology parameters. Sediment samples were air-dried, disaggregated, and packed into $5.28 \mathrm{~cm}^{3}$ plastic boxes. To measure high $(4.75 \mathrm{kHz})$ and low $(0.47 \mathrm{kHz})$ frequency magnetic susceptibility $\left(\chi_{\mathrm{hf}}, \chi_{\mathrm{ff}}\right)$, a Bartington Instruments susceptibility meter with a field of $80 \mathrm{~A} / \mathrm{m}$ was used. Magnetic susceptibility 
Table 10. Time intervals and depths in the graduated cylinder for extracting silt and clay of known sizes. (Folk, 1980).

\begin{tabular}{ccc}
\hline \hline $\begin{array}{c}\text { Phi } \\
\Phi\end{array}$ & $\begin{array}{c}\text { Time } \\
\text { (hrs:min:sec) }\end{array}$ & $\begin{array}{c}\text { Depth } \\
\text { (cm) }\end{array}$ \\
\hline 5 & $0: 01: 45$ & 10 \\
6 & $0: 06: 58$ & 10 \\
7 & $0: 28: 00$ & 10 \\
8 & $1: 51: 00$ & 10 \\
9 & $3: 42: 00$ & 5 \\
\hline
\end{tabular}


is a concentration parameter where larger values indicate greater ferrimagnetic concentration. Averages of three readings for each sample were recorded at both high and low frequencies. The frequency dependence, a magnetic grain size parameter, for each sample was calculated by the following equation:

Frequency Dependence $=\left(\left(\chi_{\mathrm{lf}}-\chi_{\mathrm{hf}}\right) / \chi_{\mathrm{lf}}\right) * 100$

A Molspin spinner magnetometer was utilized for measuring remanent magnetization. A D-Tech $2000 \mathrm{AF}$ demagnetizer was used to impart each sample with an anhysteretic remanent magnetization (ARM) at $100 \mathrm{mT}$. ARM is a measure of the amount of ferrimagnetic material in the sample and is biased toward stable single domain (SSD) particles (Evans and Heller, 2003). Next, samples were demagnetized to $40 \mathrm{mT}$ on the AF demagnetizer and measured on the Molspin. Isothermal remanent magnetization (IRM) was imparted at $1 \mathrm{~T}$ utilizing the ASC impulse magnetizer. The saturation isothermal remanent magnetization (SIRM) is the maximum magnetic remanence acquired by a sample exposed to a saturating magnetic field (Evans and Heller, 2003). For this study, the $1 \mathrm{~T}$ field was considered to yield the SIRM. A direct current (DC) demagnetization of the SIRM was achieved using an ASC impulse magnetizer at $-100 \mathrm{mT}$ and $-300 \mathrm{mT}$. From these measured remanents, the S-ratio, a magnetic minerology parameter, was calculated.

\subsubsection{Heavy Metals}

The total digestion procedure of Lacey et al. (2001) was performed on representative samples to determine the total concentration of lead $(\mathrm{Pb})$, zinc $(\mathrm{Zn})$, copper $(\mathrm{Cu})$, and chromium (Cr) in the sediment. The concentrations of $\mathrm{Pb}, \mathrm{Zn}, \mathrm{Cu}$, and $\mathrm{Cr}$ was determined with a Perkin-Elmer 7000 Atomic Absorption Spectrometer (AA). Instrument 
concentration readings were then converted from $\mathrm{mg} / \mathrm{L}$ to $\mu \mathrm{g} / \mathrm{g}$ by using the following equation:

Metal concentration $(\mu \mathrm{g} / \mathrm{g})=\mathrm{AA}$ conc. $(\mathrm{mg} / \mathrm{L}) *(50 \mathrm{~mL}$ soln/sed $\mathrm{wt} \mathrm{g}) *$ $(1000 \mu \mathrm{g} / 1 \mathrm{mg}) *(1 \mathrm{~L} / 1000 \mathrm{~g})$

Four replica samples, two acid blanks, and two samples of National Institute of Standards and Technology (NIST) Buffalo River reference material \#8704, were measured. The acid blanks were processed to check for contamination during the total digestion process (Table 11). The blank samples were below detection for all four metals, indicating that there was no contamination. The Buffalo River reference material \#8704 was processed to determine the effectiveness of the total digestion method with known values for heavy metals.

Initially, the $\mathrm{Pb}$ and $\mathrm{Cr}$ concentrations for Buffalo River reference material \#8704 (BRS) had anomalous percent recovery rates of $145 \%$ for $\mathrm{Pb}$ and $81 \%$ for $\mathrm{Cr}$. The AA was found to have a drain blockage that affected the sample input and sample readings. The blockage was fixed, and the all samples were remeasured for new $\mathrm{Pb}$ and $\mathrm{Cr}$ concentrations. The new percent recovery was $99 \%$ for $\mathrm{Pb}$ and $91 \%$ for $\mathrm{Cr}$ the BRS. The close agreement between measured and reported BRS metal concentrations indicate an effective total digestion processes (Table 11).

\subsection{GIS Procedures}

GIS procedures were conducted using ArcMap to establish land cover percentages and areas and quantify land cover changes from 1985 to 2010 in Haskell Run, Ritchie Run, and Mud Brook watersheds. Additionally, the shorelines at the deltas for Lake Butler, Lake Litchfield, and Old Mill Pond were assessed. 


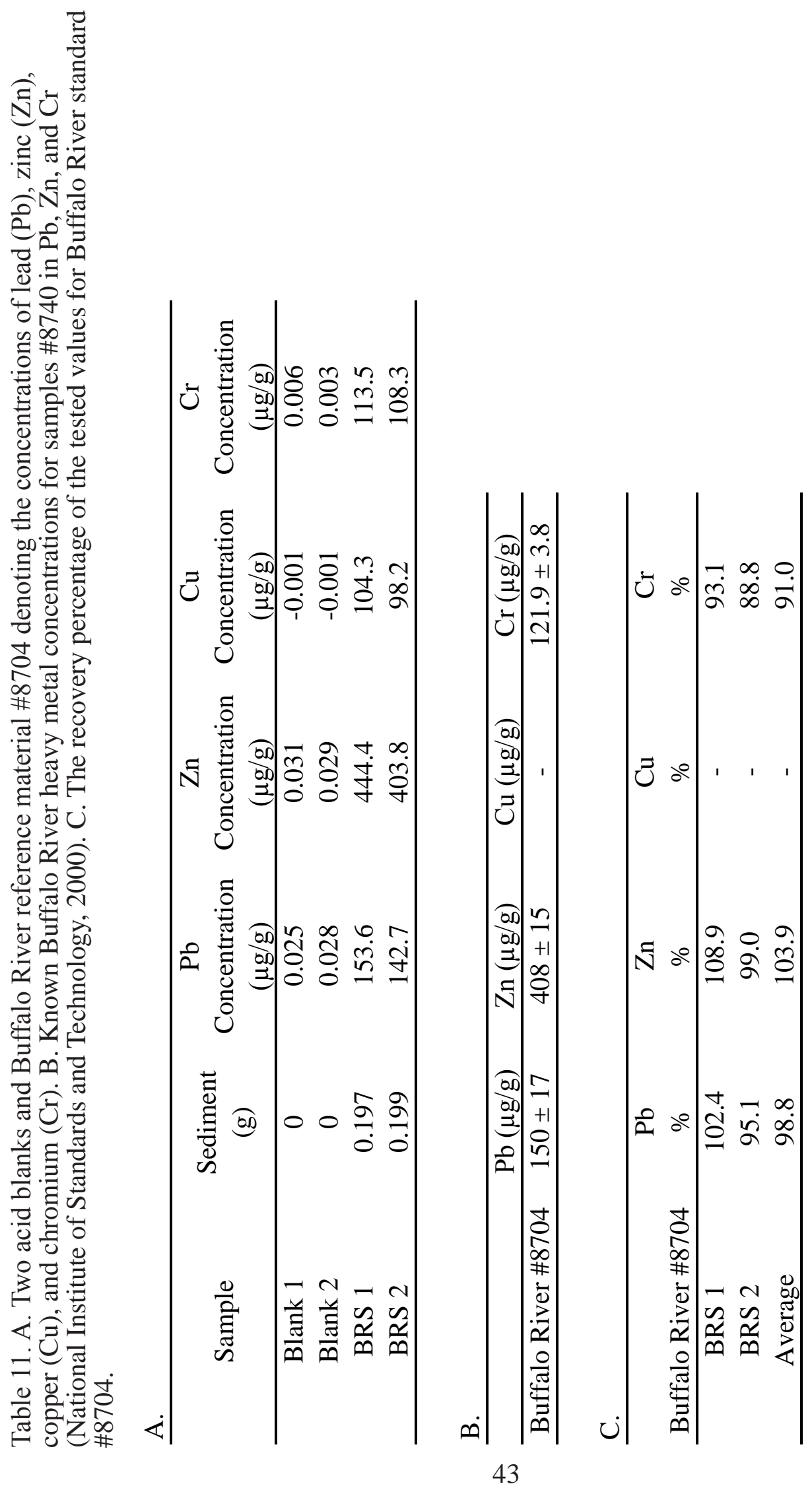




\subsubsection{Land Cover Change}

Land cover changes in both the Mud Brook and Haskell Run/Ritchie Run watersheds were quantified utilizing ArcGIS software. All three sites are subwatersheds of the Cuyahoga River. The subwatershed study sites were delineated utilizing the GIS pour point method with a 1/9th arc second Digital Elevation Model (DEM) raster file (Parmenter and Melcher, 2012). First, the DEMs projected coordinates were changed to NAD 1983 (2011) StatePlane Ohio North FIPS 3401 (US Feet). Flow direction in each site area was determined from the DEMs. Flow accumulation (accumulated flow from each cell to the next) was calculated from the new filled DEM identifying flow within the area. The watershed boundaries for all three subwatersheds was not accurate initially. The watersheds were edited and reshaped based on a visual assessment of ridges and elevation changes using the ESRI topography map, current aerial photos, and the Summit County Fiscal Office defined watershed boundaries (Table 12). The Lake Butler subwatershed flows from the headwaters of Haskell Run to the lake dam. The Lake Litchfield subwatershed mainly flows from the headwaters of Ritchie Run to the lake dam. Old Mill Pond/Mud Brook subwatershed starts at Lake Wyoga and flows to the Old Mill Pond dam.

The data sets used for land cover change analysis were from NOAA Digital Coast for the years 1985, 1996, 2001, 2006, and 2010 (Table 12; Digital Coast, 2016a). The Mud Brook, Haskell Run, and Ritchie Run subwatershed boundaries were used to clip the land cover data sets to analyze only the land cover within each subwatershed. The cell sizes for the land cover data was 30 X 30 meters. Land cover data was classified using the NOAA Digital Coast C-CAP classification system. The four main reclassified groups of land cover assessed were: developed, farmland, undeveloped, and open water (Digital Coast, 2016b). Developed land in this study is comprised of five classes: high intensity, medium intensity, low intensity, open spaces, and barren land. For the purposes of this 


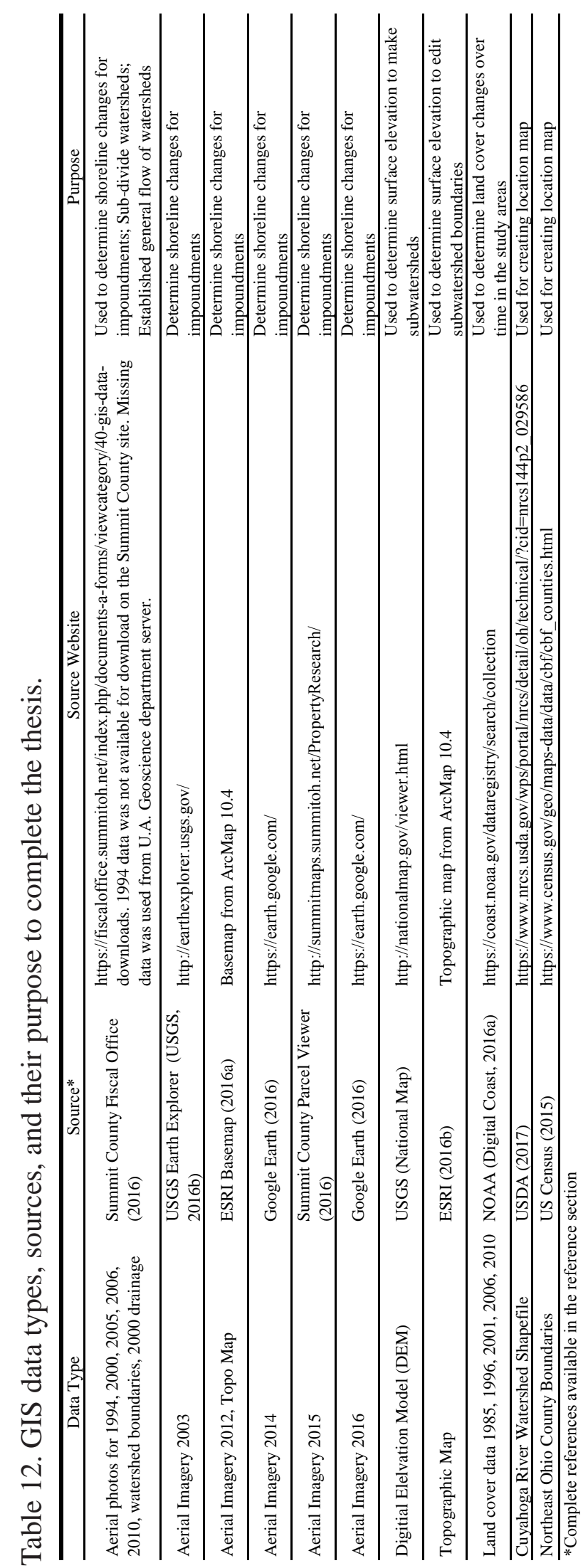


study, barren land in the final assessment was included in the developed category owing to its runoff potential. Farmland consists of the classes cultivated crops and pasture/ hay. Undeveloped land includes the remaining categories (i.e., grassland/herbaceous, deciduous forest, evergreen forests, mix forest, and palustrine forest, scrub, and emergent wetlands) except for open water. Land cover classes within each subwatershed were then assessed by total area and total percent to quantify the amount of land cover change over time.

Impervious land cover values were determined by multiplying a specific coefficient for each land cover class by the area for each site. Land cover class coefficients were calculated using NOAA’s Impervious Surface Analysis Tool (ISAT) accounting for high, medium, and low values based on the population density or people per square mile (Table 13). High population density for the ISAT method is $>2,500$ people $/ \mathrm{mi}^{2}$, medium population density is $<2,500$ to $>500$ people $/ \mathrm{mi}^{2}$, and low population density is $<500$ people/mi² (Digital Coast, 2017).

\subsubsection{Shoreline Assessment}

Aerial photos from 1994, 2000, 2003, 2005, 2006, 2010, 2012, 2014, 2015, and 2016 were used to assess changes in the delta shorelines within each impoundment (Table 12; ESRI, 2016; Google, 2016; Summit County Parcel Viewer, 2016; Summit County Fiscal Office, 2016; USGS, 2016b). The aerial photo from 2015 was georeferenced from Summit County (Summit County Parcel Viewer, 2016) and years 2014 and 2016 were georeferenced from Google Earth (Google, 2016). Images were georeferenced by utilizing the ArcMap georeferencing tool. At least eight reference points were identified with the first order polynomial transformation and maximum residual distance of 0.9 meters, modified from the procedure of Delaney (2016). 
Table 13. Impervious coefficients derived from population density (population/ sq. mi.) from the NOAA Impervious Surface Analysis Tool (ISAT) and NLCD (2006) impervious data. Population classifications: Low: $<=500$; Medium: $>500$ and $<=2500$; High: $>2500$ (Digital Coast, 2017).

\begin{tabular}{ccccc}
\hline \hline \multirow{2}{*}{ Land Cover } & Land Cover & \multicolumn{3}{c}{ Impervious coefficients based on } \\
Code & Class Name & High & Medium & Low \\
\hline 0 & Unclassified & 0.00 & 0.00 & 0.00 \\
2 & Developed, High Intensity & 76.45 & 76.61 & 76.36 \\
3 & Developed, Medium Intensity & 49.21 & 49.02 & 48.99 \\
4 & Developed, Low Intensity & 25.72 & 25.55 & 25.57 \\
5 & Developed, Open Space & 11.15 & 10.95 & 10.93 \\
6 & Cultivated Crops & 3.21 & 2.59 & 2.44 \\
7 & Pasture/Hay & 2.06 & 1.51 & 1.40 \\
8 & Grassland/Herbaceous & 9.30 & 8.74 & 8.47 \\
9 & Deciduous Forest & 2.18 & 1.88 & 1.77 \\
10 & Evergreen Forest & 1.44 & 1.23 & 1.20 \\
11 & Mixed Forest & 2.74 & 2.22 & 2.08 \\
12 & Scrub/Shrub & 3.86 & 3.50 & 3.28 \\
13 & Palustrine Forested Wetland & 1.16 & 0.96 & 0.92 \\
14 & Palustrine Scrub/Shrub Wetland & 1.31 & 1.27 & 1.26 \\
15 & Palustrine Emergent Wetland & 1.46 & 1.44 & 1.46 \\
20 & Bare Land & 14.91 & 14.73 & 14.49 \\
21 & Open Water & 0.82 & 0.89 & 1.00 \\
\hline
\end{tabular}



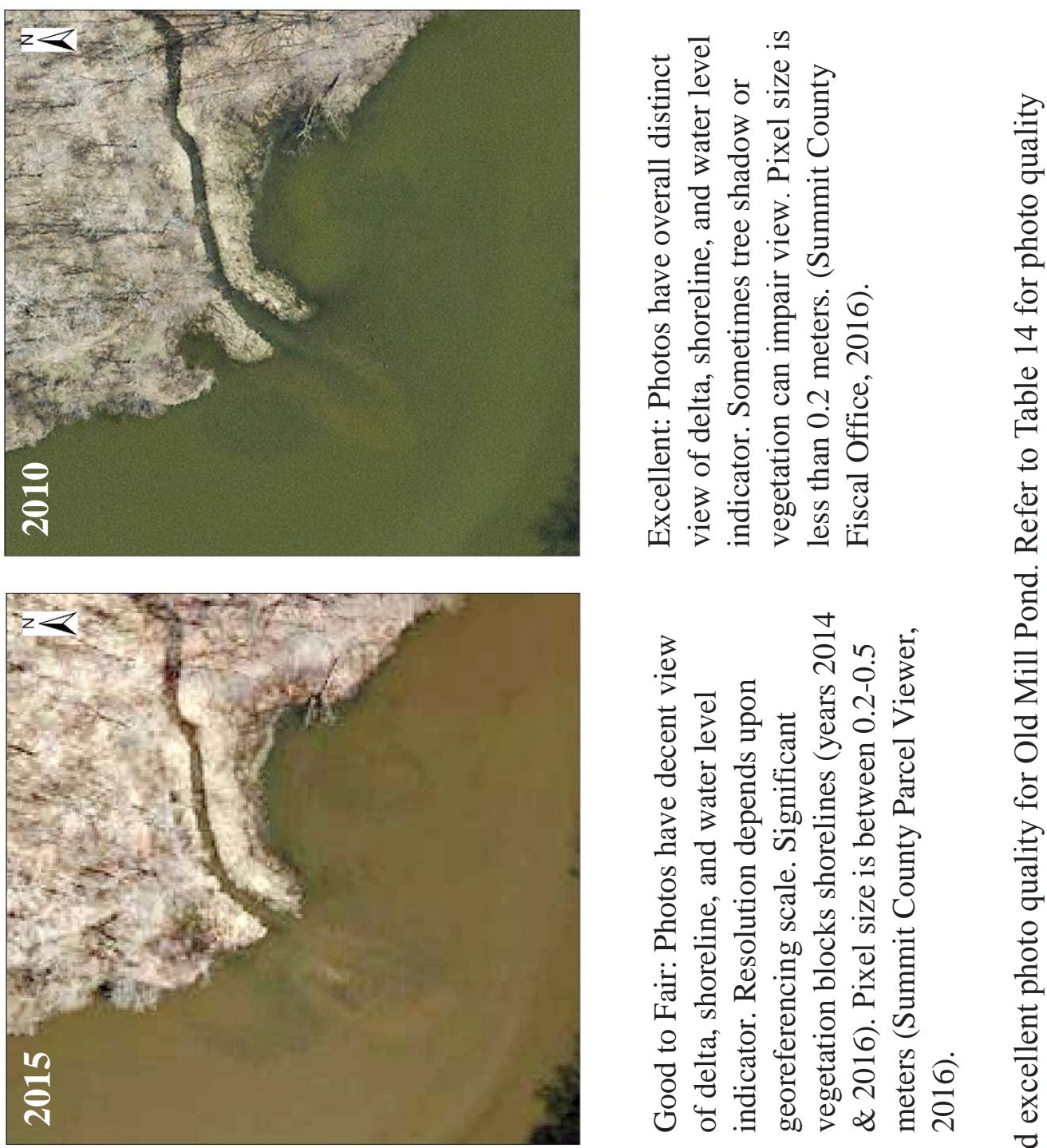

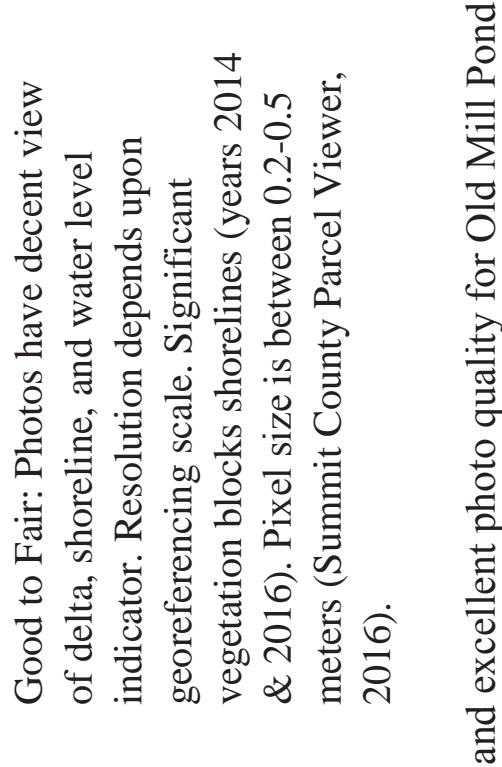
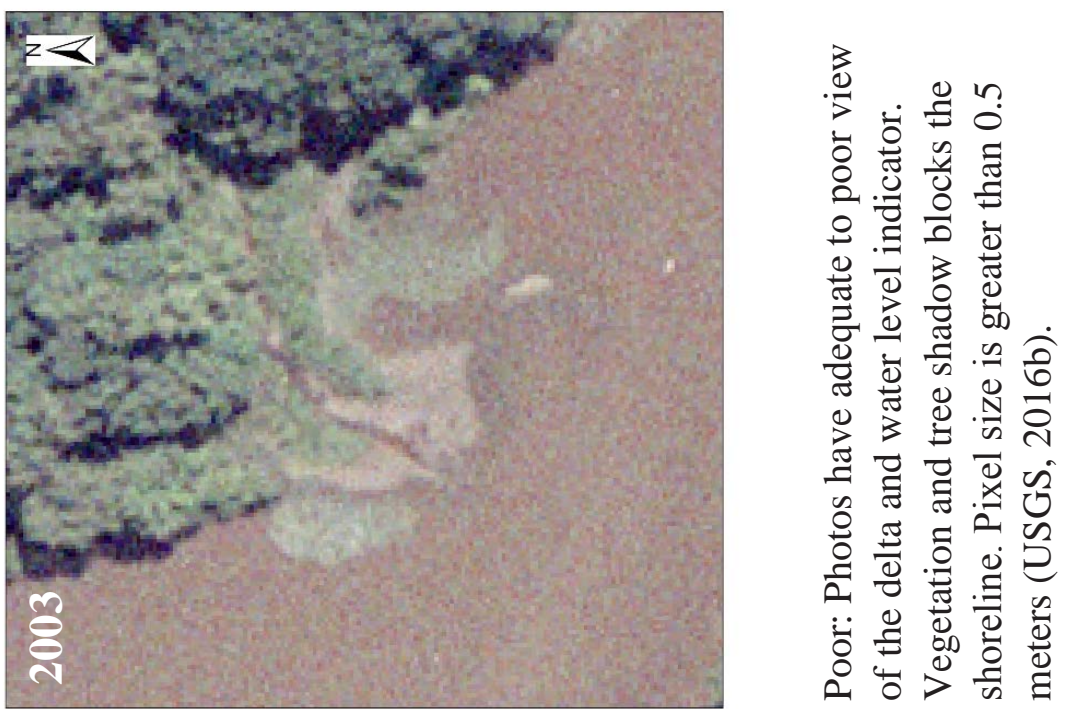

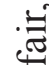

응

苍

월을

클

开

N

일 
Table 14. Aerial orthophotos used to assess shoreline change, organized by year.

\begin{tabular}{|c|c|c|}
\hline Year of Photo & Photo Source & Quality \\
\hline 1994 & Summit County Fiscal Office, 2015 & $\begin{array}{l}\text { Good-Fair Quality: Resolution is fair. Deltas, } \\
\text { shorelines, and streams can be seen clearly. }\end{array}$ \\
\hline 2000 & Summit County Fiscal Office, 2015 & $\begin{array}{l}\text { Excellent Quality: Resolution was excellent. Delta } \\
\text { and water level indicators could be seen clearly. }\end{array}$ \\
\hline 2003 & USGS Earth Explorer & $\begin{array}{l}\text { Poor Quality: Resolution poor. Vegetation } \\
\text { covered delta shorelines. Some general } \\
\text { characteristics could be deteremined (e.g., stream } \\
\text { path in Lake Butler). }\end{array}$ \\
\hline 2005 & Summit County Fiscal Office, 2015 & $\begin{array}{l}\text { Excellent Quality: Resolution was excellent. Delta } \\
\text { and water level indicators could be seen clearly. }\end{array}$ \\
\hline 2006 & Summit County Fiscal Office, 2015 & $\begin{array}{l}\text { Excellent Quality: Resolution was excellent. } \\
\text { Delta, shorelines, and water level indicators could } \\
\text { be seen clearly. }\end{array}$ \\
\hline 2010 & Summit County Fiscal Office, 2015 & $\begin{array}{l}\text { Excellent Quality: Resolution was excellent. } \\
\text { Delta, shorelines, and water level indicators could } \\
\text { be seen clearly. }\end{array}$ \\
\hline 2012 & ESRI, 2016 & $\begin{array}{l}\text { Good to Excellent Quality: Resolution was } \\
\text { generally excellent, however some images were } \\
\text { affected by tree shade. }\end{array}$ \\
\hline 2014 & Google, 2016 & $\begin{array}{l}\text { Good to Fair Quality: Resolution depended upon } \\
\text { georeferencing scale. Vegetation prevented some } \\
\text { shorelines to be seen. }\end{array}$ \\
\hline 2015 & Summit County Parcel Viewer, 2016 & $\begin{array}{l}\text { Good to Fair Quality: Resolution depended upon } \\
\text { georeferencing scale. }\end{array}$ \\
\hline 2016 & Google, 2016 & $\begin{array}{l}\text { Good to Fair Quality: Resolution depended upon } \\
\text { georeferencing scale. Some sections of the delta } \\
\text { were blocked by vegetation. }\end{array}$ \\
\hline
\end{tabular}


Photo quality and tree shadows greatly affected the visibility of the shoreline (Figure 17, Table 14). The delta shorelines were digitized utilizing the polygon tool primarily at scales between 1:150 and 1:400. Depending on the image quality, the scale would vary to make viewing the shoreline easier. Variations in the impoundment water level affects shoreline position; therefore, a fixed object or shoreline was identified at each site to compare relative lake level changes between photo years. At Lake Butler, a shoreline section between two trees from the year 2000 was used for a lake level indicator. At Lake Litchfield, a rounded shoreline section near the delta from the year 2000 was used. At Old Mill Pond a concrete-type structure near the delta was utilized. For each year, the lake level was denoted as deeper, shallower, or the same relative to the position of the shoreline reference year or if the object was observed in the photo. A problem lies in the time periods when the photos were taken. These photos are from one day in a year. The impoundment level could be higher or lower due to changes in the precipitation and stream discharge rates on that day. Lake Butler was drained in 2015, and thus the impoundment water level appears different than other years. Regarding sediment deposits, there was no significant deposition of sediment in any particular year after 2003. The delta, however, did show progradation from 1994 to 2016 as indicated by the delta environment transition from subaqueous delta front to delta top. 


\section{CHAPTER III}

\section{RESULTS}

\subsection{Lake Butler}

Surficial and core sediment properties in addition to the trapping efficiency were measured and analyzed for Lake Butler. The shorelines at the Lake Butler delta were assessed from 1994 to 2016. Haskell Run watershed land cover changes were evaluated from 1985 to 2010.

\subsubsection{Surface Samples}

Seven samples were collected from Lake Butler, two from the delta at the head of the impoundment, and five from Haskell Run which flows into Lake Butler (Table 15). The impoundment samples consisted of a tan clay overlying an organic black mud. The stream samples ranged from medium sand to granule size. Porosity (the water percentage for a fully saturated sample), organic matter content, dry bulk density, mass-corrected susceptibility $(\chi)$, and visual grain size were evaluated for all surface samples (Table 15). Sand and gravel samples had low porosity (24-52\%), low organic content (1.9-4.5\%), and a high dry bulk density, whereas mud samples had high porosity (57.3-73.4\%), high organic content (6.1-14.1\%), and lower dry bulk density (0.3-0.5 g/ $\left.\mathrm{cm}^{3}\right)$. All samples had a uniform mass-corrected susceptibility $\left(\chi_{\mathrm{lf}}\right)$, ranging from $20.2-38.010^{-8} \mathrm{~m}^{3} \mathrm{~kg}^{-1}$, with one outlier at sample G13 $\left(68.510^{-8} \mathrm{~m}^{3} \mathrm{~kg}^{-1}\right)$ from upstream in Haskell Run. The grain size for sample G14, collected where Haskell Run meets Lake Butler, was measured to be poorly sorted coarse sand (Table 16). Three surface samples $(\mathrm{G} 4,5,7)$ were analyzed for $\mathrm{Pb}, \mathrm{Zn}$, $\mathrm{Cu}$, and $\mathrm{Cr}$ heavy metal concentrations (Table 17). Pb concentrations ranged between 10- 


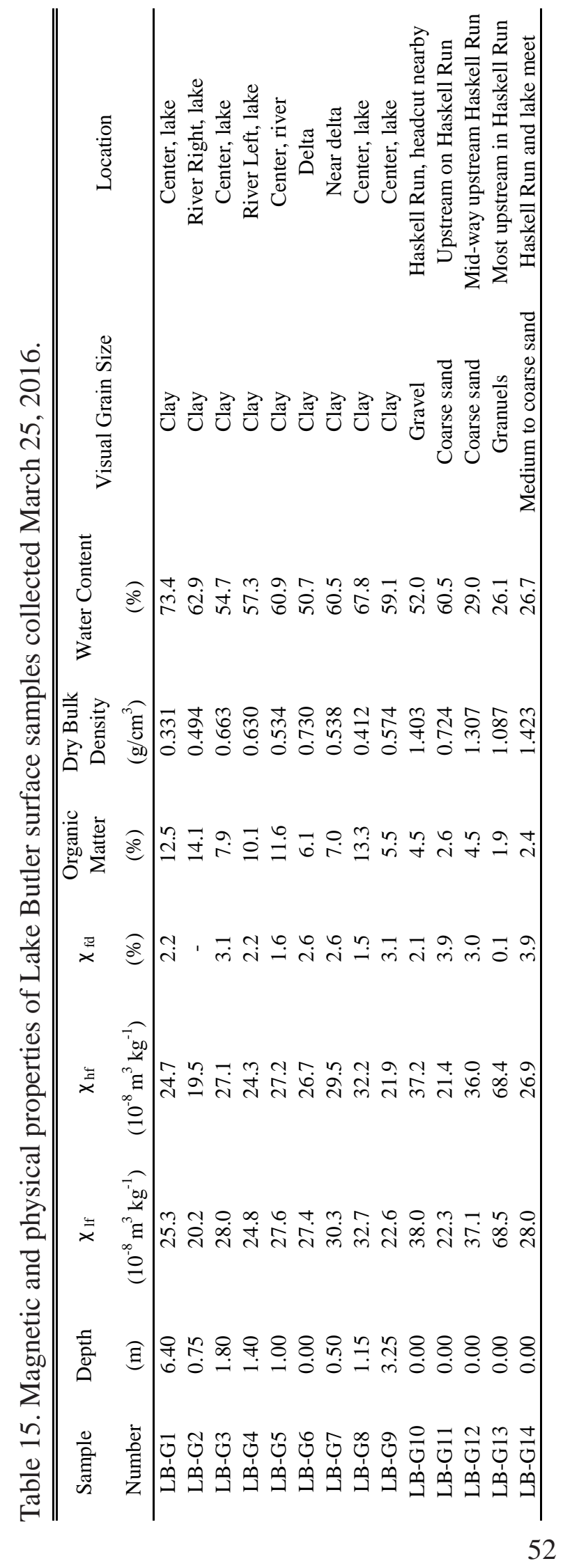




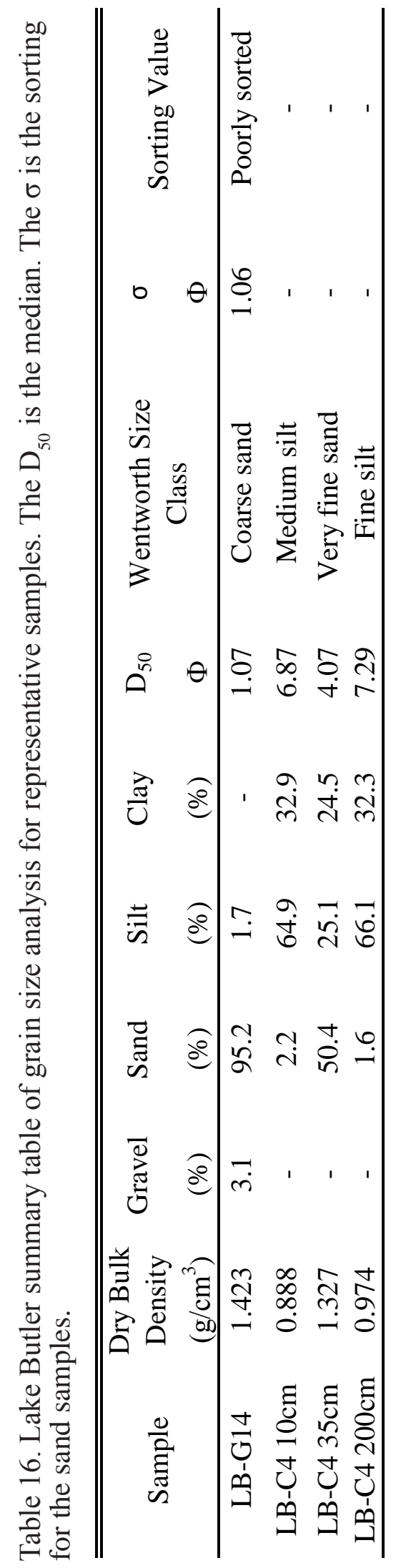


Table 17. Heavy metal concentrations for selected Lake Butler sediment samples.

\begin{tabular}{lcccc}
\hline \hline Sample & $\begin{array}{c}\mathrm{Pb} \\
\text { Concentration } \\
(\mu \mathrm{g} / \mathrm{g})\end{array}$ & $\begin{array}{c}\mathrm{Zn} \\
\text { Concentration } \\
(\mu \mathrm{g} / \mathrm{g})\end{array}$ & $\begin{array}{c}\mathrm{Cu} \\
\text { Concentration } \\
(\mu \mathrm{g} / \mathrm{g})\end{array}$ & $\begin{array}{c}\mathrm{Cr} \\
\text { Concentration } \\
(\mu \mathrm{g} / \mathrm{g})\end{array}$ \\
\hline \multicolumn{1}{c}{ Surface } & & & & \\
LB-G4 & 35.3 & 153.2 & 23.3 & 56.9 \\
LB-G5 & 26.1 & 139.3 & 26.1 & 55.3 \\
LB-G5 Rep & 26.3 & 132.4 & 28.1 & 57.9 \\
LB-G7 & 10.6 & 155.8 & 27.1 & 58.8 \\
\multicolumn{1}{c}{ Core } & & & & \\
LB-C4 0cm & 8.5 & 119.0 & 16.8 & 46.8 \\
LB-C4 50cm & 19.1 & 169.6 & 20.9 & 61.8 \\
LB-C4 101cm & 16.8 & 252.0 & 14.6 & 49.8 \\
LB-C4 150cm & 19.3 & 709.4 & 35.1 & 62.4 \\
LB-C4 200cm & 13.5 & 124.5 & 32.4 & 52.0 \\
\hline
\end{tabular}


$35 \mu \mathrm{g} / \mathrm{g}, \mathrm{Zn}$ concentrations were between 132-156 $\mu \mathrm{g} / \mathrm{g}, \mathrm{Cu}$ concentrations were between 23-28 $\mu \mathrm{g} / \mathrm{g}$, and $\mathrm{Cr}$ concentrations ranged from $55-58 \mu \mathrm{g} / \mathrm{g}$. These samples were also tested for magnetic properties including ferrimagnetic concentration, magnetic grain size,

and mineralogy (Table 18). The magnetic concentration parameters SIRM, $\chi_{\mathrm{If}}$, and $\chi \mathrm{ARM}$ are largely a measure of the ferrimagnetic (low coercively) mineral content in a sample (Evans and Heller, 2003). The saturation isothermal remanent magnetization (SIRM) for these surface samples is on average $2,40010^{-6} \mathrm{Am}^{2} \mathrm{~kg}^{-1}$, the magnetic susceptibility ( $\chi \mathrm{lf}$ ) is on average $2810^{-8} \mathrm{Am}^{3} \mathrm{~kg}^{-1}$, and the anhysteretic remanent magnetization ( $\left.\chi \mathrm{ARM}\right)$ is on average $1.110^{-6} \mathrm{~m}^{3} \mathrm{~kg}^{-1}$. The S-ratio, a magnetic mineralogy indicator, is approximately 0.9 suggesting that both ferrimagnetic minerals (e.g., magnetite) and high coercively mineral (e.g., hematite or goethite) are present.

\subsubsection{Trapping Efficiency}

The sediment trapping efficiency of Lake Butler was determined by collecting inflow and outflow data on two dates (March 25 and November 21, 2016). Water discharge (Qw) and total suspended sediment (TSS) concentrations were measured so that suspended sediment discharge (Qs) could be calculated for the inflow and outflow (Appendix A). The lake was drained before the March data collection to repair a valve. Water level at that time was approximately a foot below normal level. In November, the lake was at the normal pool lake level. In March, water discharge at the inflow was $0.055 \mathrm{~m}^{3} / \mathrm{s}$ and the outflow was $0.061 \mathrm{~m}^{3} / \mathrm{s}$ (Appendix A). The difference in discharge between the two sites is not significant and therefore the lake was not draining. Inflow TSS was higher in Haskell Run and on average lower in the lake and at the outflow culvert. During this time, the outflow Qs was about $1.32 \mathrm{~g} / \mathrm{sec}$. In November, discharge at the inflow and outflow sites were low (inflow $=0.016$; outflow $=0.011 \mathrm{~m}^{3} / \mathrm{s}$ ). November TSS was lower than in March, indicating the water was less turbid in November. Qs values in the lake were 


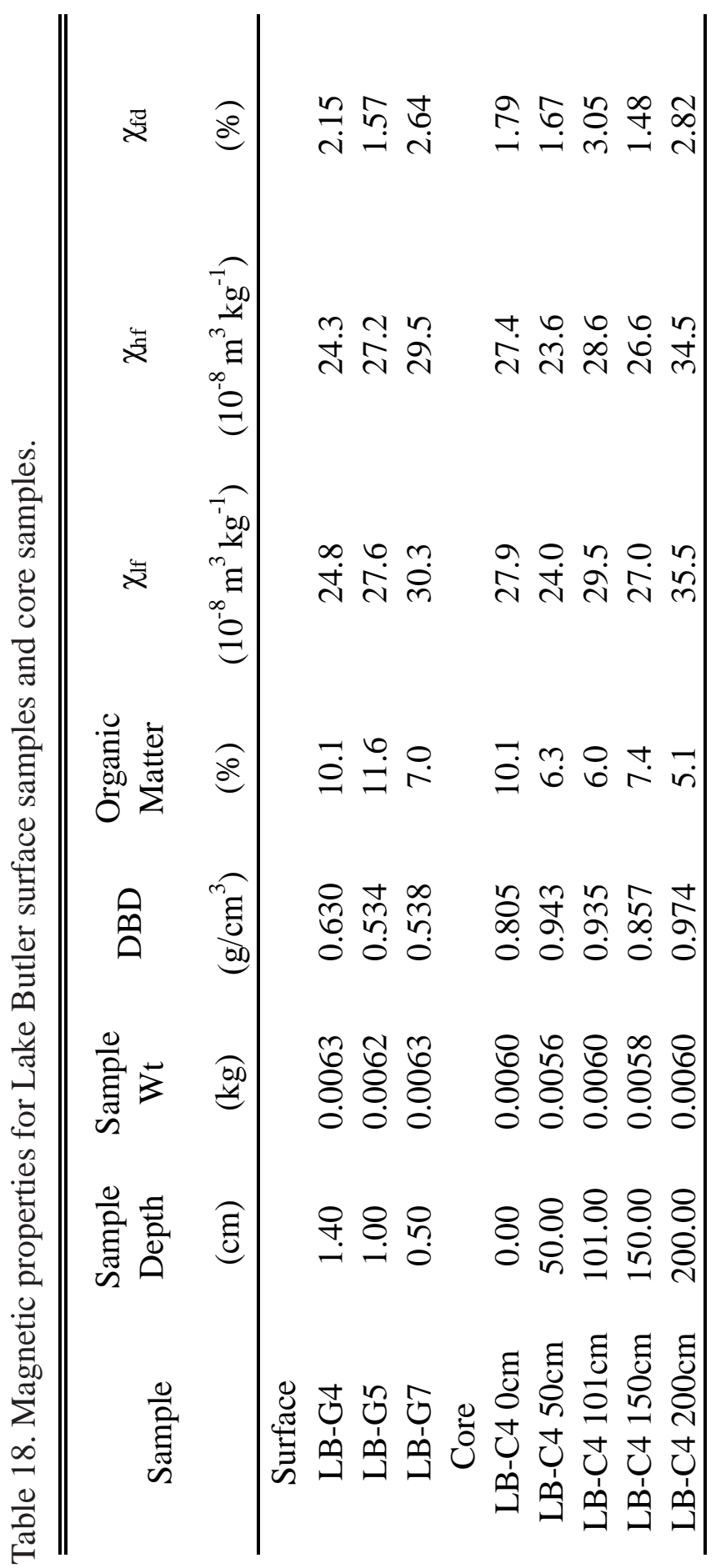




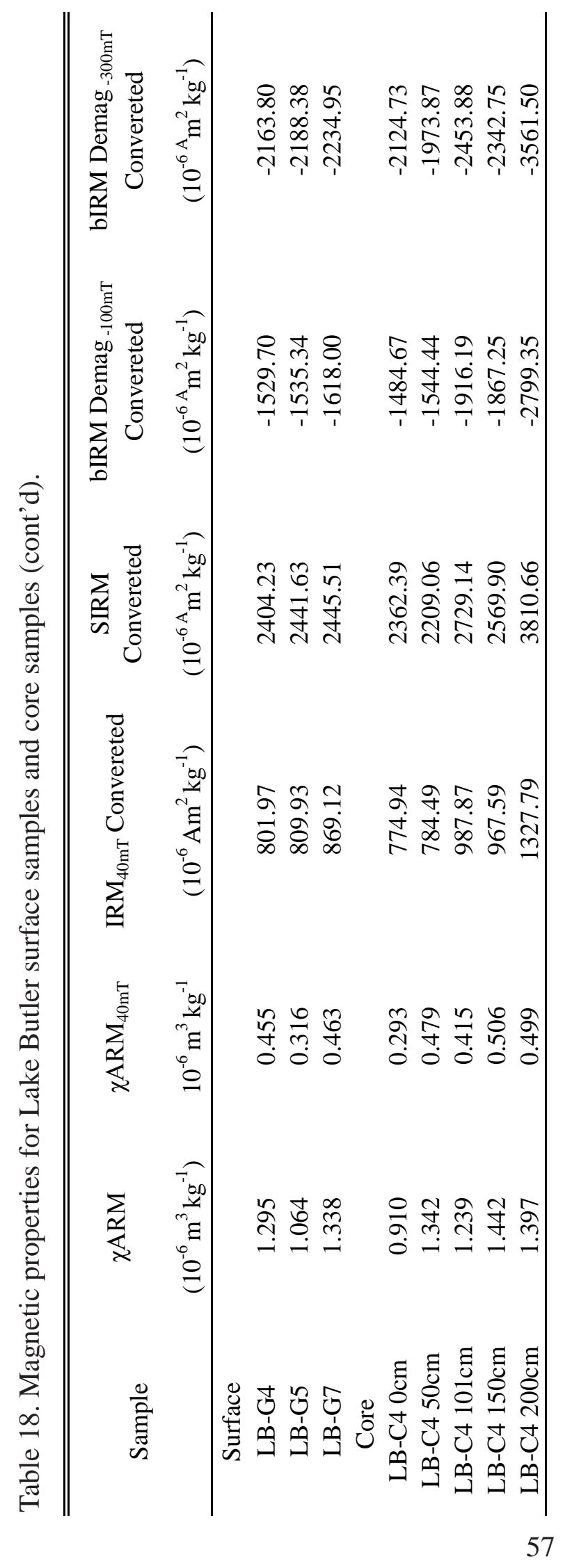


Table 18. Magnetic properties for Lake Butler surface samples and core samples (cont'd).

\begin{tabular}{cccc}
\hline \hline Sample & S-ratio & SIRM/ $\chi$ & \\
& & $\left(10^{2} \mathrm{~A} / \mathrm{m}\right)$ & $\chi_{\text {ARM }} / \chi$ \\
\hline Surface & & & \\
LB-G4 & 0.900 & 96.94 & 5.221 \\
LB-G5 & 0.896 & 88.46 & 3.855 \\
LB-G7 & 0.914 & 80.71 & 4.417 \\
Core & & & \\
LB-C4 0cm & 0.899 & 84.67 & 3.261 \\
LB-C4 50cm & 0.894 & 92.04 & 5.593 \\
LB-C4 101cm & 0.899 & 92.51 & 5.349 \\
LB-C4 150cm & 0.912 & 95.18 & 3.934 \\
LB-C4 200cm & 0.935 & 107.34 & \\
\hline
\end{tabular}


also comparatively low, signifying more sediment was being transported in March than in November.

\subsubsection{Sediment Cores}

Sediment cores were collected from Lake Butler in March and May of 2016. Cores were taken from the delta top (LB-16-C1 and LB-16-C4) and from the pro-delta lake floor (LB-16-C7). Cores where evaluated for visual lithology, organic matter content, dry bulk density, grain size, heavy metal concentrations, and magnetic properties.

Delta top core LB-16-C4 is $249 \mathrm{~cm}$ long and can be divided into three main sections: 249-203 cm, 203-45 cm, and 45-0 cm (Figures 18 and 19). From 249 to 203 cm core depth, the lithology is primarily medium sand with granules in the bottom $8 \mathrm{~cm}$. The granules at the bottom $8 \mathrm{~cm}$ are similar to the granules found in the channel of Haskell Run (sample G13). The whole-core susceptibility ( $\kappa)$ in this section is the highest in the entire core. The organic matter content increases slightly up core, with a peak value in a wood debris layer. Bulk density at the bottom $8 \mathrm{~cm}$ of $\mathrm{C} 4$ is $1.7 \mathrm{~g} / \mathrm{cm}^{3}$, then gradually decreases $\sim 1.2 \mathrm{~g} / \mathrm{cm}^{3}$. Between 203-45 cm, there are three lithologies present; however, $\kappa$ is uniform throughout the section. The predominant lithology is a dark grey clay.

In the clay units, organic matter and dry bulk density remain constant. The $\mathrm{D}_{50}$ of the sediment at $200 \mathrm{~cm}$ core depth was determined to be fine silt (Table 16). Sand is present at 147-142 cm and 80-76 cm core depth, accompanied by a decrease in organic matter content and a slight increase in dry bulk density. Layers of woody debris and are present at $114-105 \mathrm{~cm}$ and at 76-74 cm. In these woody debris layers, there is an organic matter increase and a dry bulk density decrease. Between 45-0 cm core depth, there are three lithologies present: sand, black clay, and mud. In this section, at $35 \mathrm{~cm}$, the sediment contains 50\% sand and 25\% silt and 25\% clay with a high dry bulk density and a low 


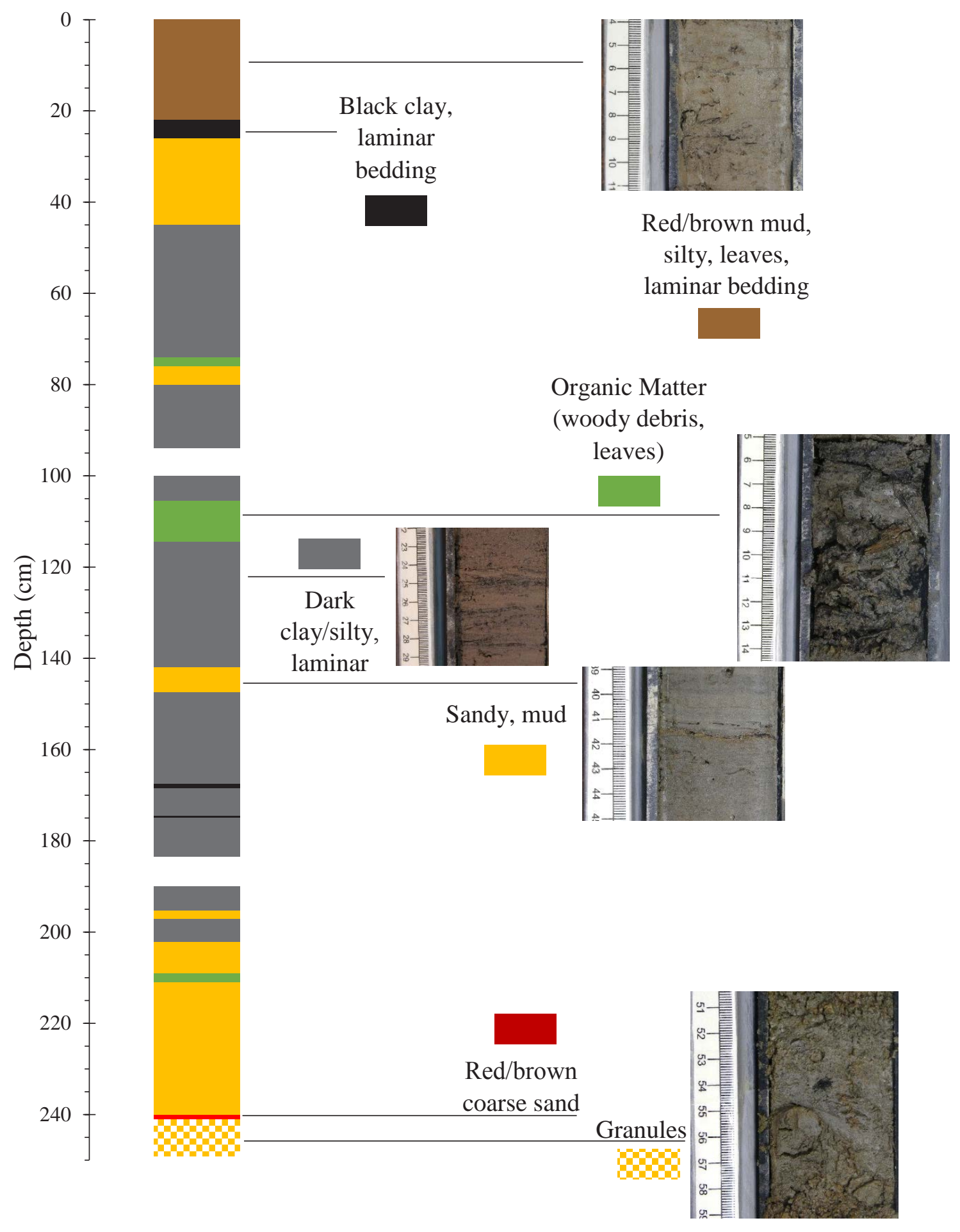

Figure 18. Detailed lithology description for Lake Butler sediment core LB-16-C4. 


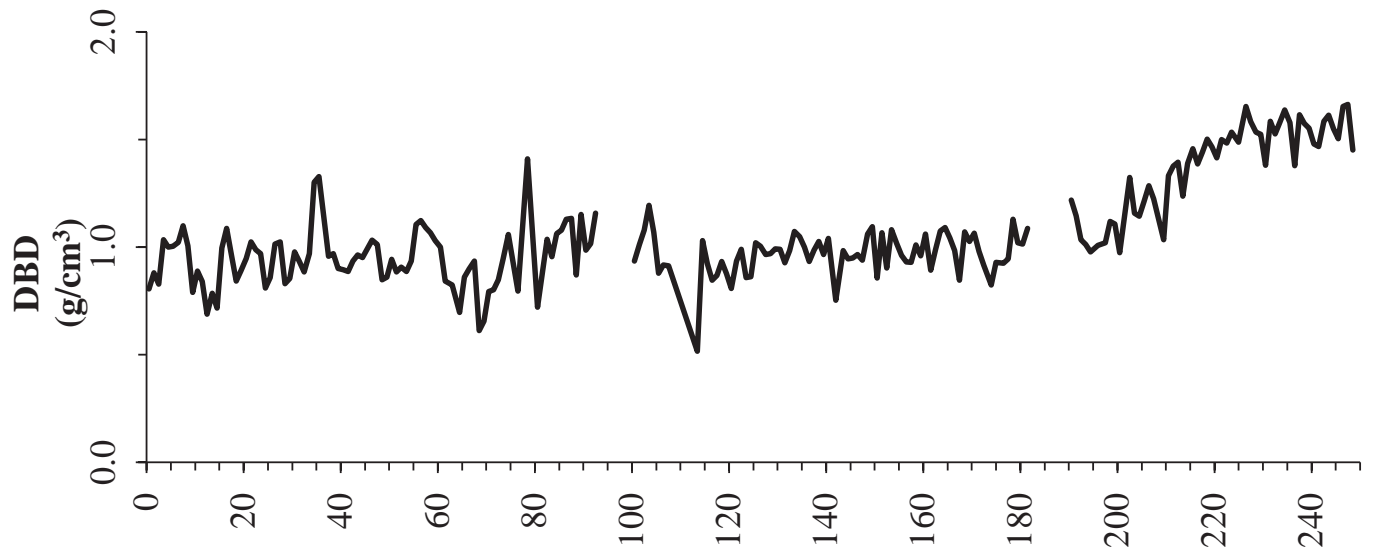

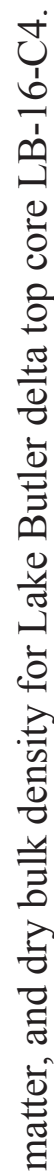

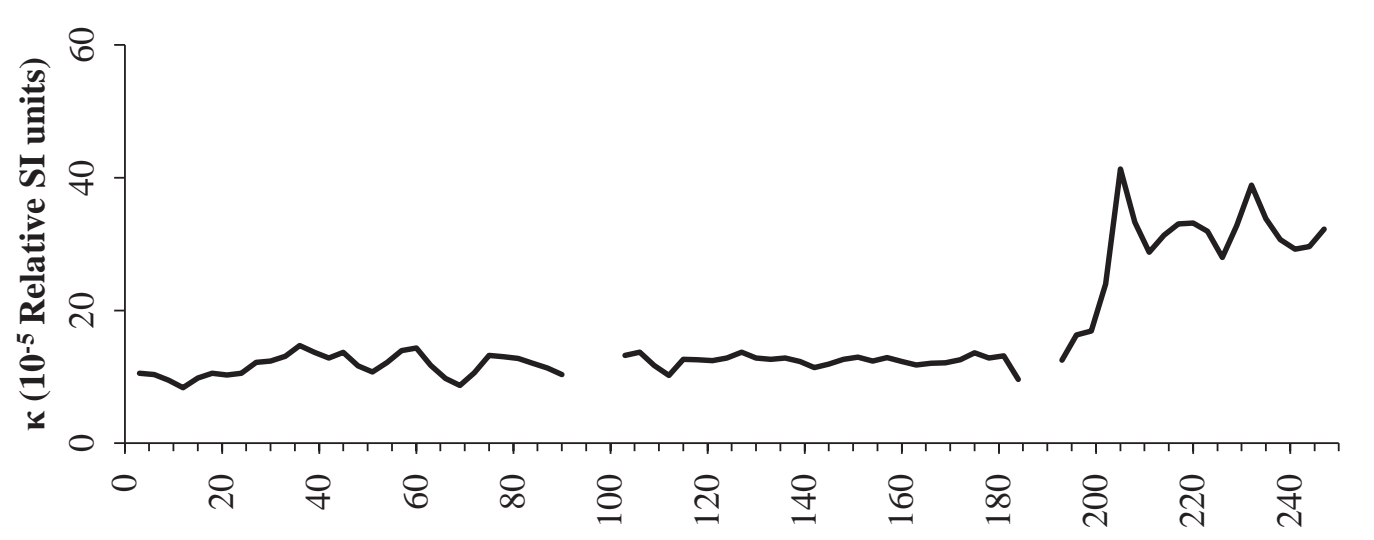

을
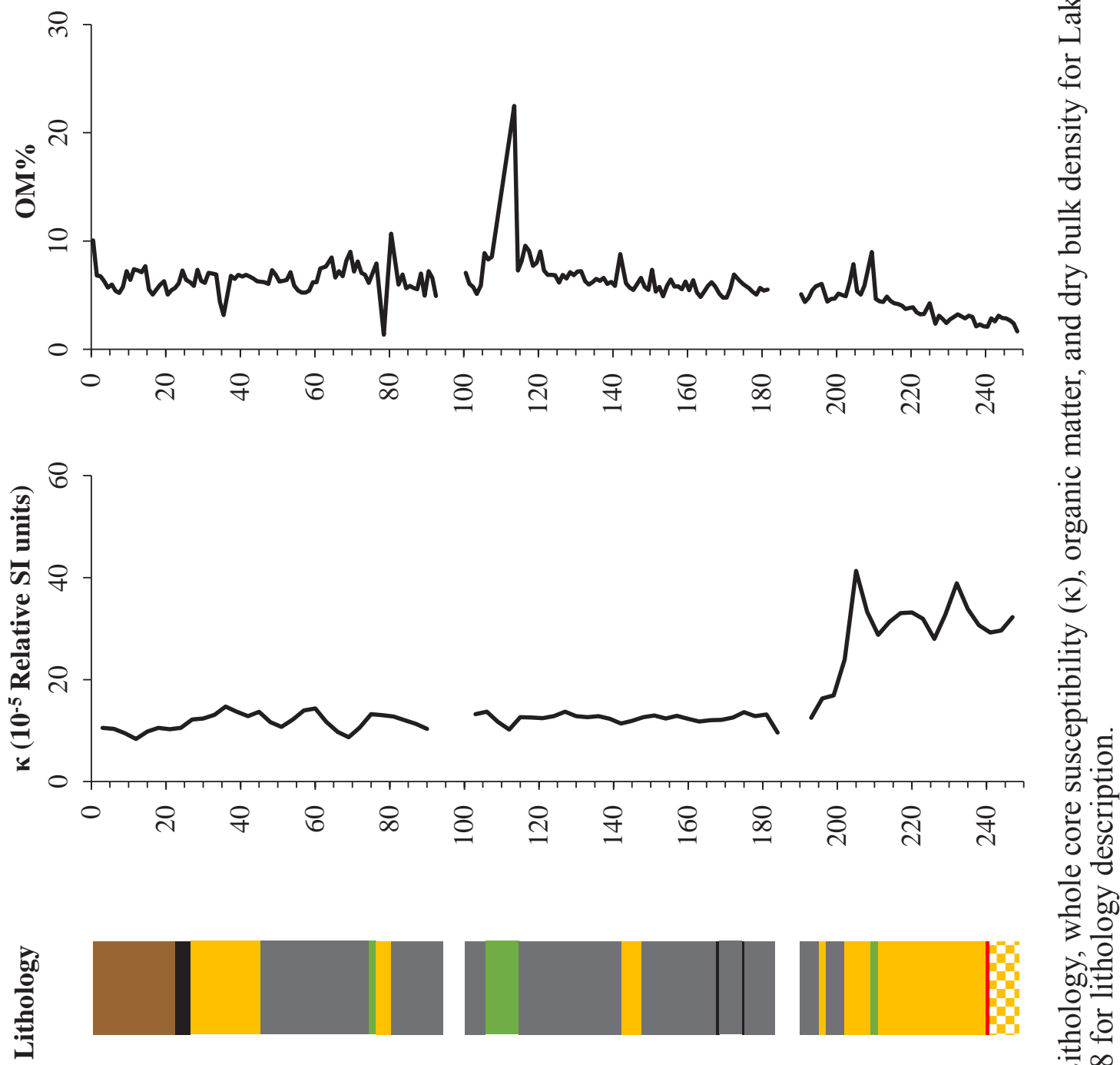

造

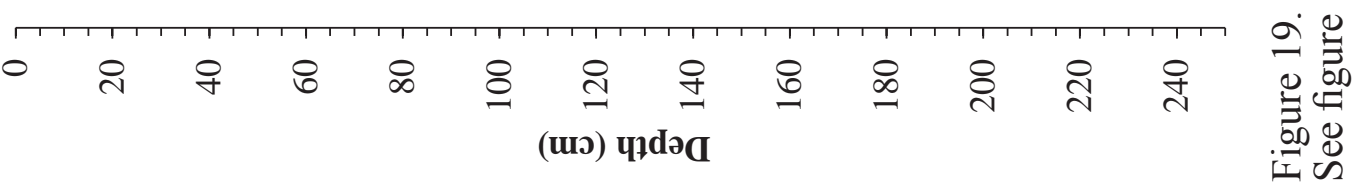




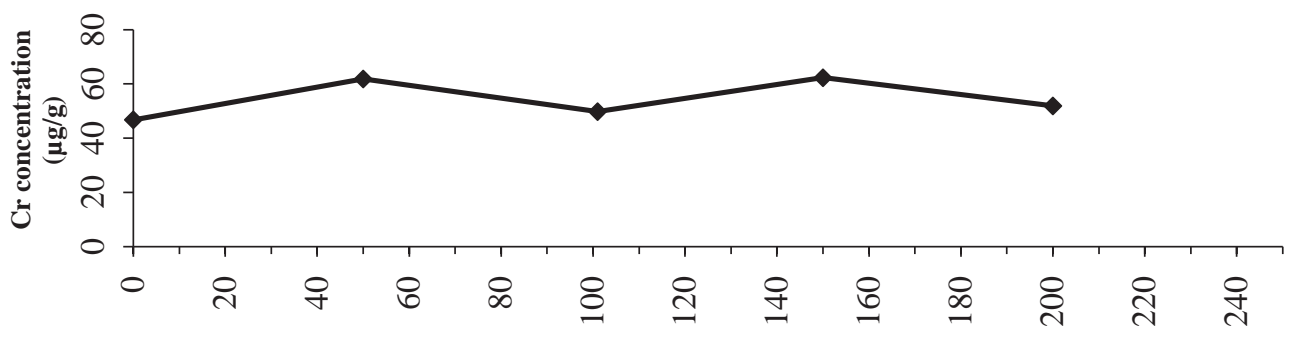

जี

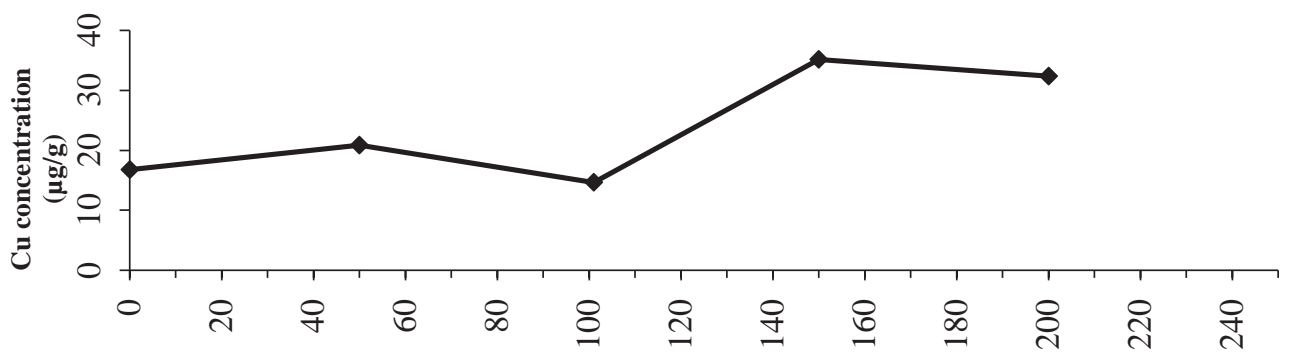

.0

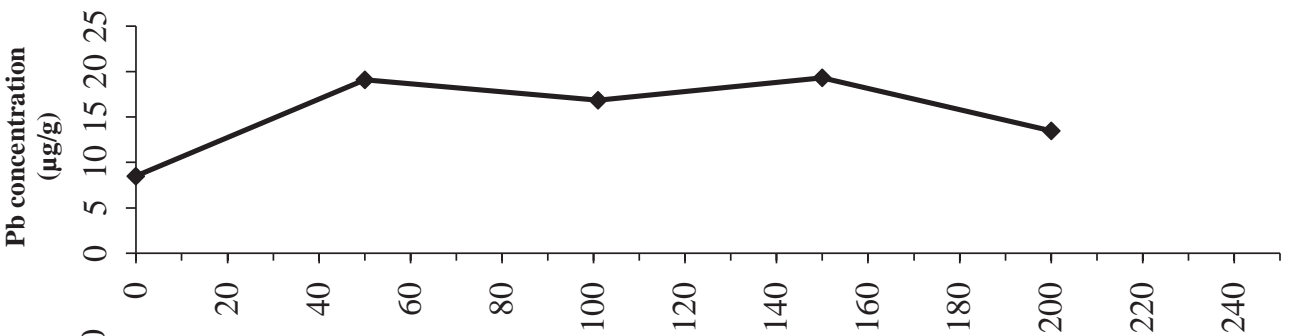

త্త
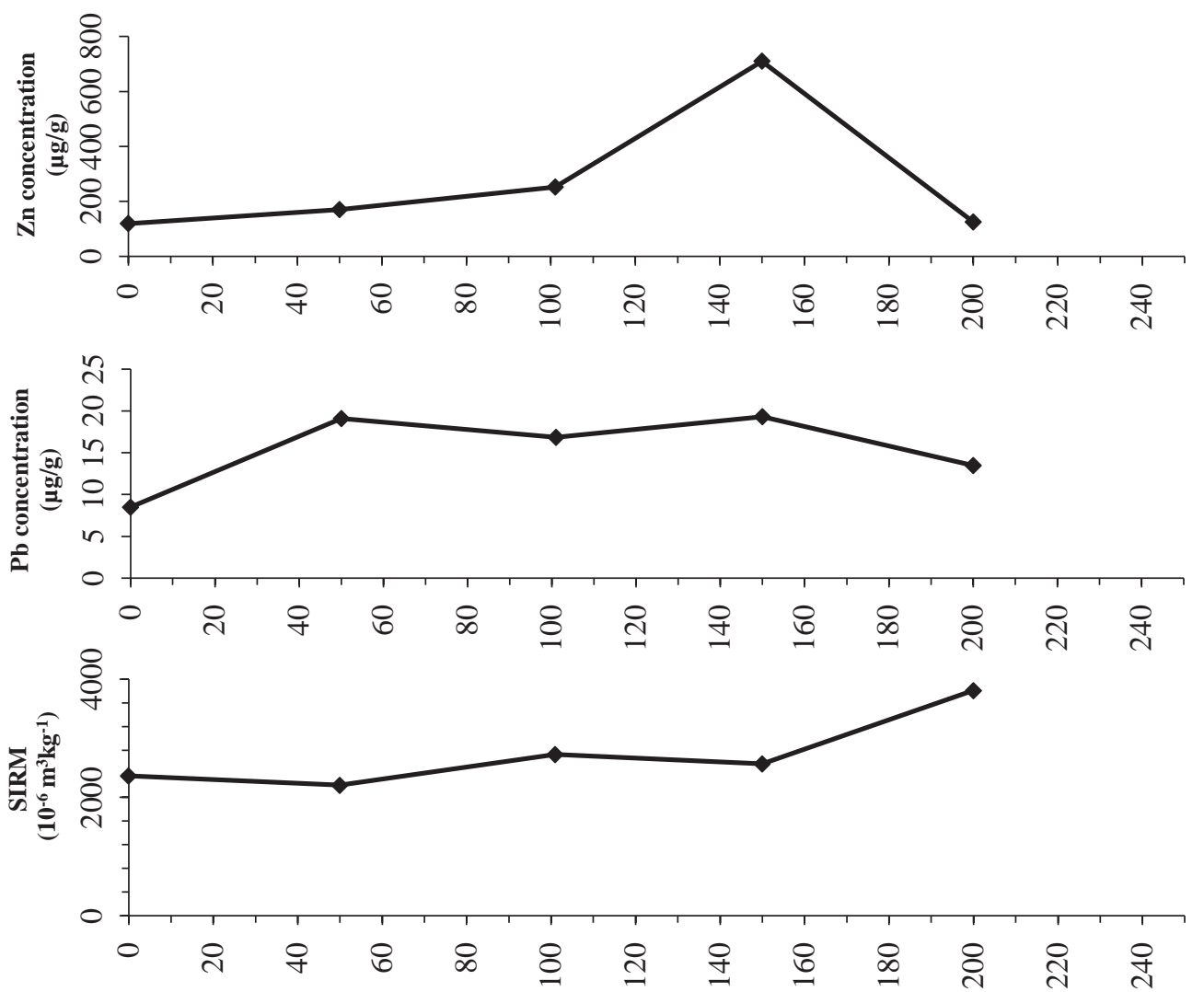

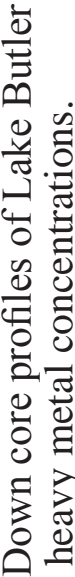
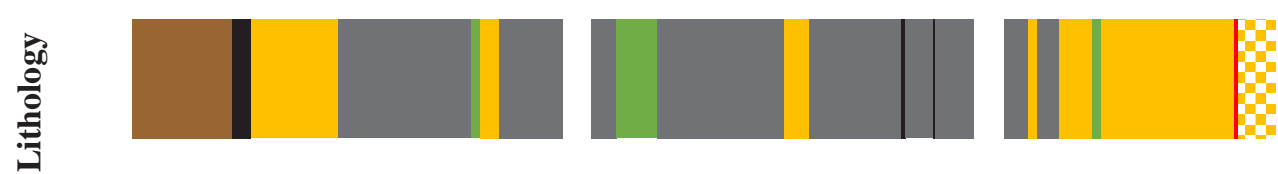

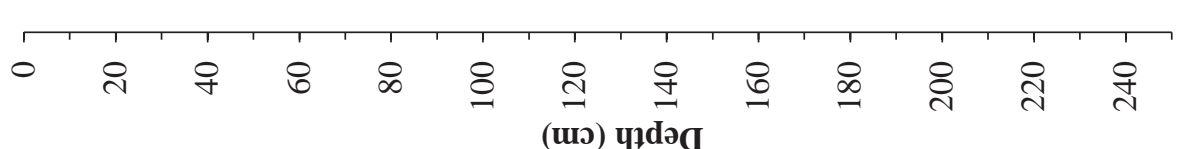

워

을

这 
organic matter content (Table 16). The $\kappa$ profile is uniform throughout this section, whereas, organic matter content and dry bulk density are variable.

Heavy metal concentrations for $\mathrm{Pb}, \mathrm{Zn}, \mathrm{Cu}$, and $\mathrm{Cr}$ were analyzed for five down core samples in core C4 (Figure 20; Table 17). From 200 to $50 \mathrm{~cm}$ core depth, $\mathrm{Pb}$ and Cr concentrations are largely uniform, and at the top of the core, both metal concentrations drop slightly. Cu concentrations are slightly larger between 200-150 cm than between 100-0 cm. Zn concentration throughout the core is uniform, except at $150 \mathrm{~cm}$ depth, where the concentration increases to $709 \mu \mathrm{g} / \mathrm{g}$. There are no corresponding increases in $\mathrm{Pb}, \mathrm{Cu}$, or $\mathrm{Cr}$ metal concentrations at $150 \mathrm{~cm}$ core depth.

The magnetic concentration parameters $\chi_{\mathrm{If}}$, SIRM and $\chi \mathrm{ARM}$ are uniform and low throughout the core, indicating low concentrations of ferrimagnetic minerals are present (Figures 21 and 22; Table 18). Three of the five downcore samples have less than $2 \%$ frequency dependence, indicating that they do not contain superparamagnetic grains (SPM). The other two samples are above $2 \%$, indicating that they contain superparamagnetic grains (Figure 23). The magnetic grain size parameters $\chi \mathrm{ARM} / \chi$ and $\mathrm{SIRM} / \chi$ show little variation down core. The S-ratio indicates most samples plot at about 0.9 , indicating that there is a mixture of high and low coercively minerals present.

The second delta top core (C1) was taken close to C4. The core was not as long as C4; however, the core data show similar trends in $\kappa$, organic matter, and bulk density (Appendix B). Throughout the core, $\kappa$ was uniform. The woody debris layers, between 115-90 cm, were high in organic matter content (20\%) and had a low bulk density (0.5 $\mathrm{g} / \mathrm{cm}^{3}$ ). Interbedded sand and clay layers were present between $90-47 \mathrm{~cm}$, having a low organic matter content (1-7\%) and bulk density around $1.0 \mathrm{~g} / \mathrm{cm}^{3}$. Silty mud and clay layers in the uppermost $47 \mathrm{~cm}$ showed moderate levels in organic matter and dry bulk density. 


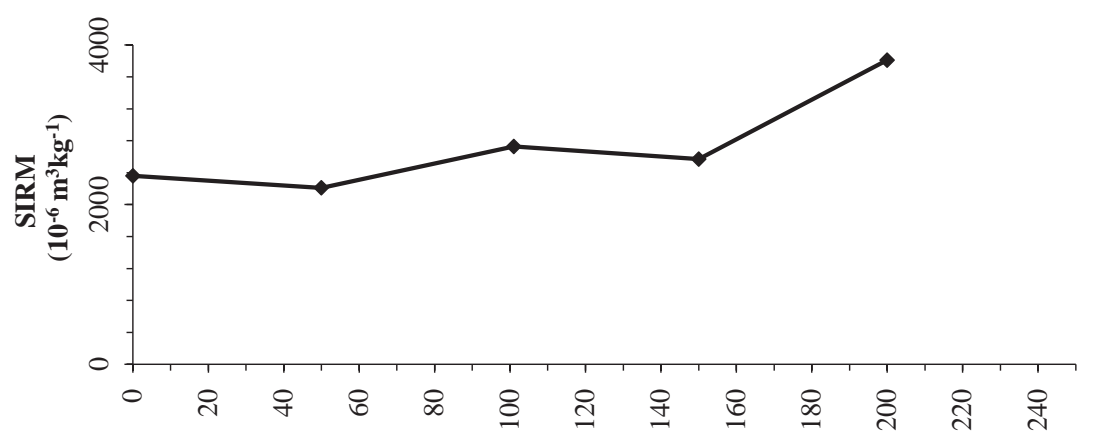

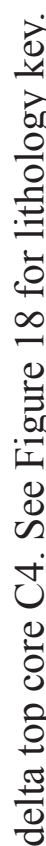
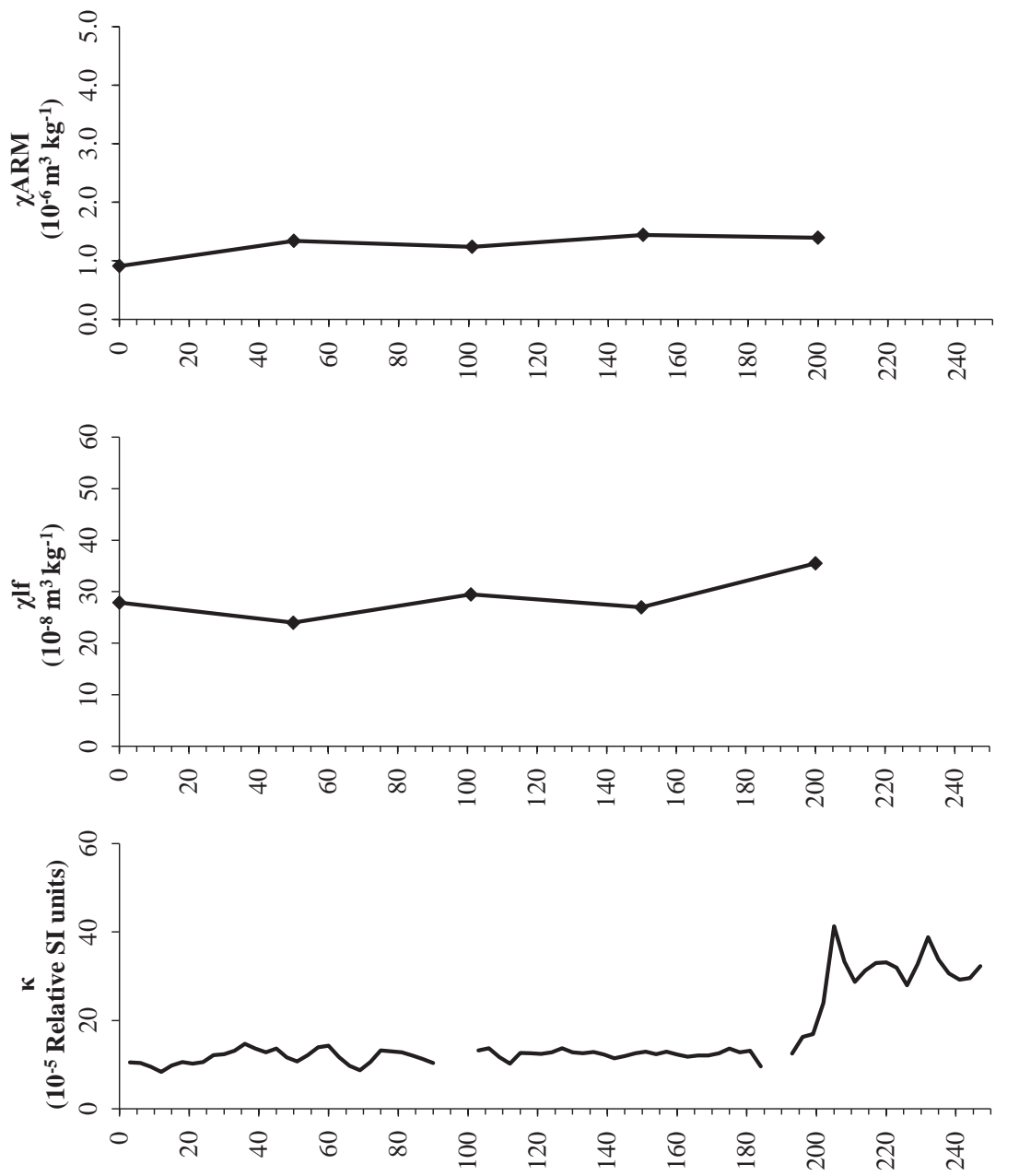

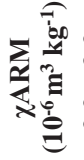

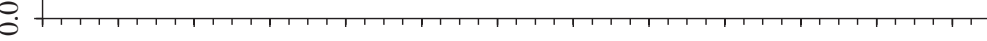

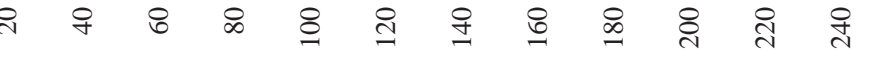

㫕
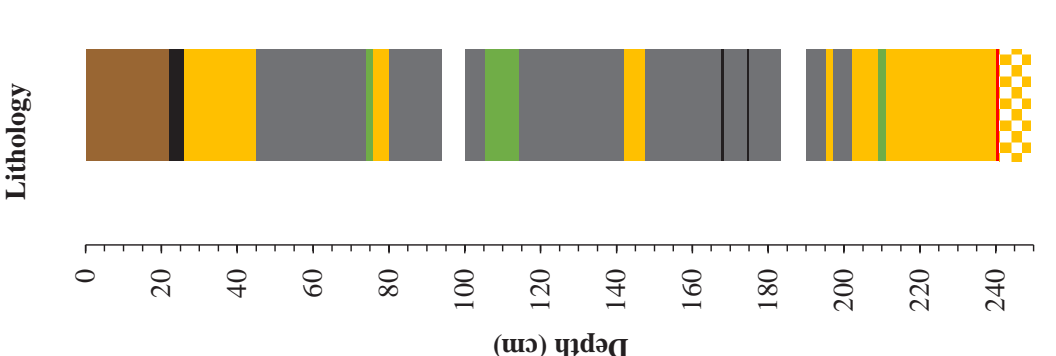

(แั) ч)dәव 

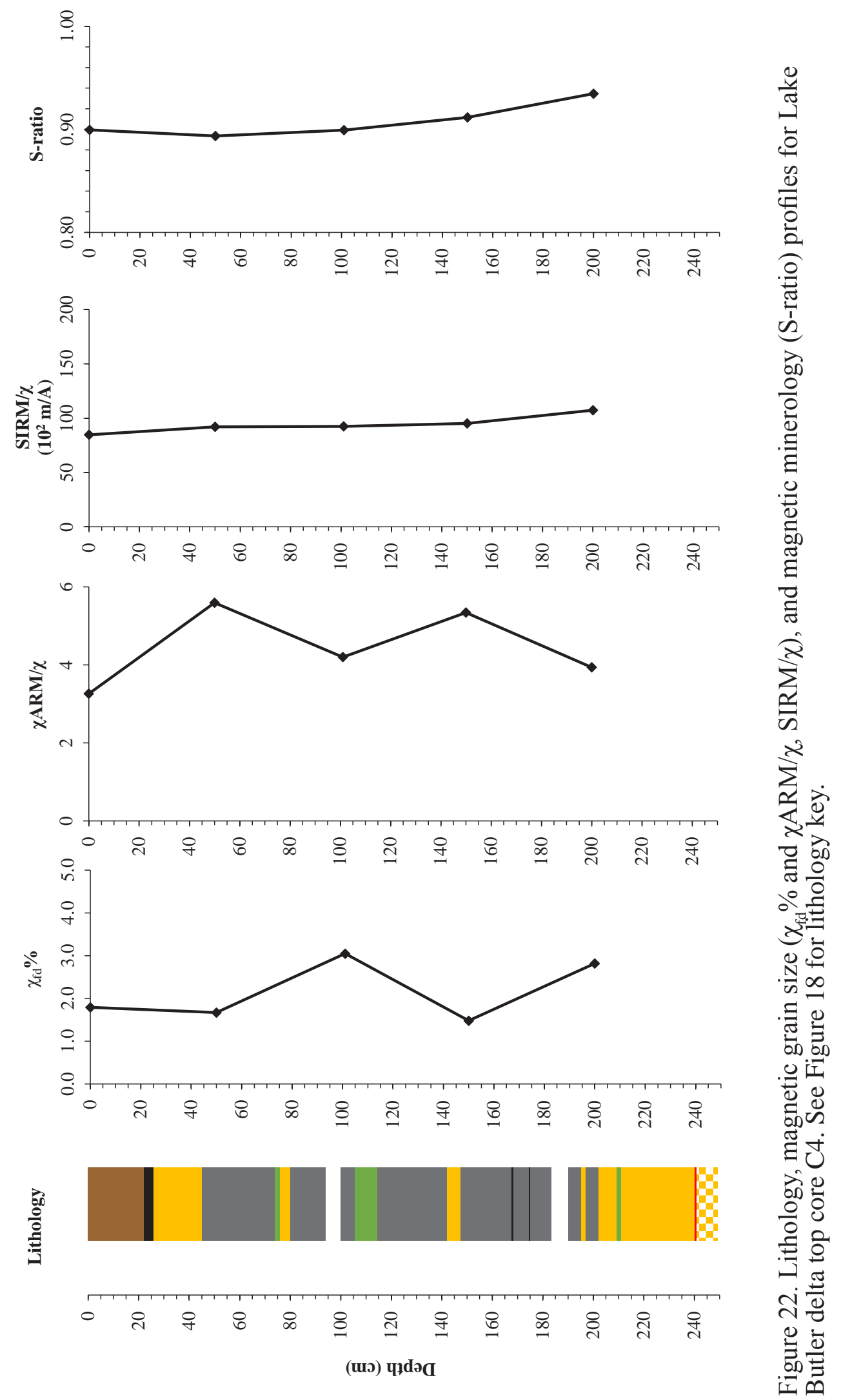


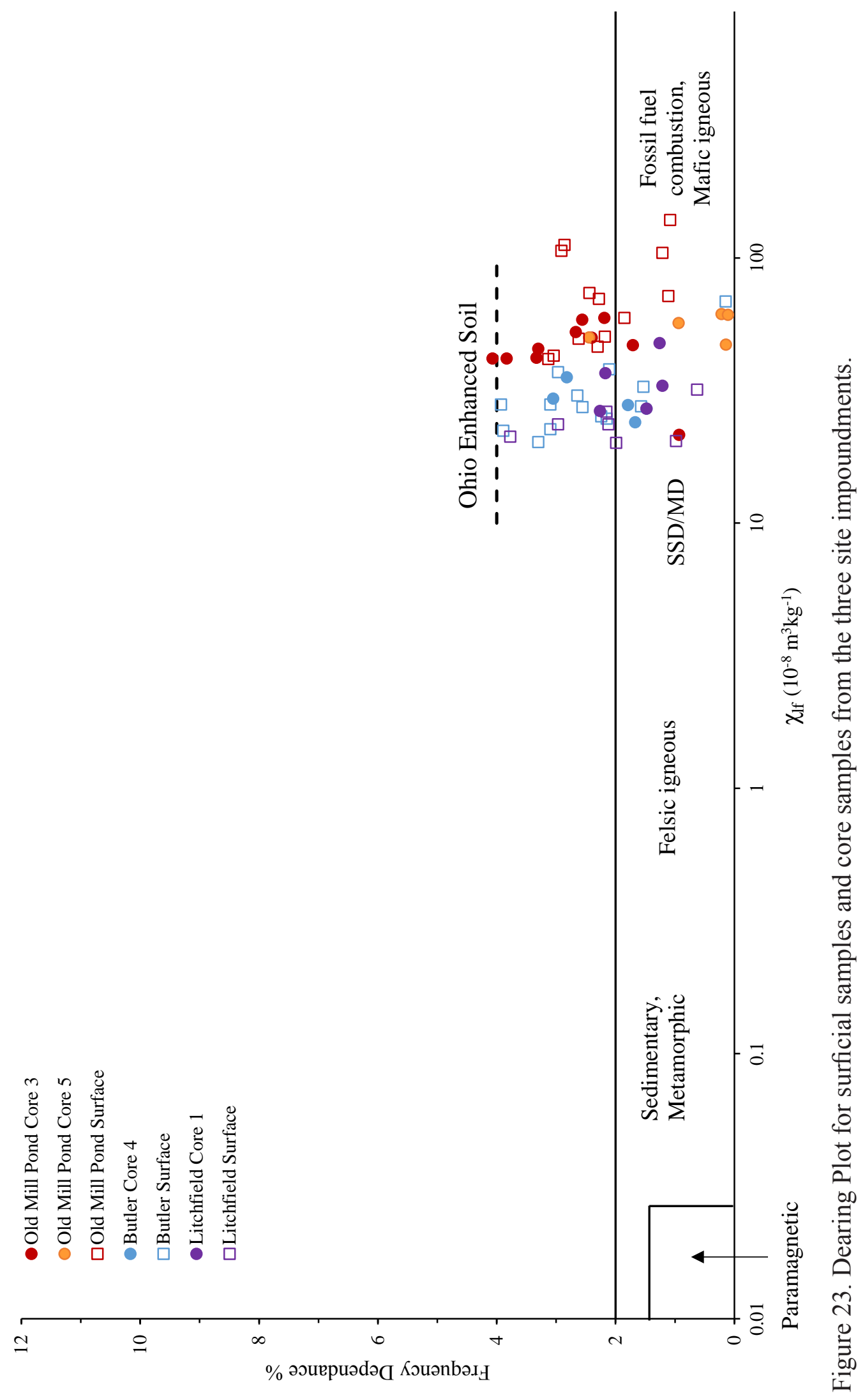




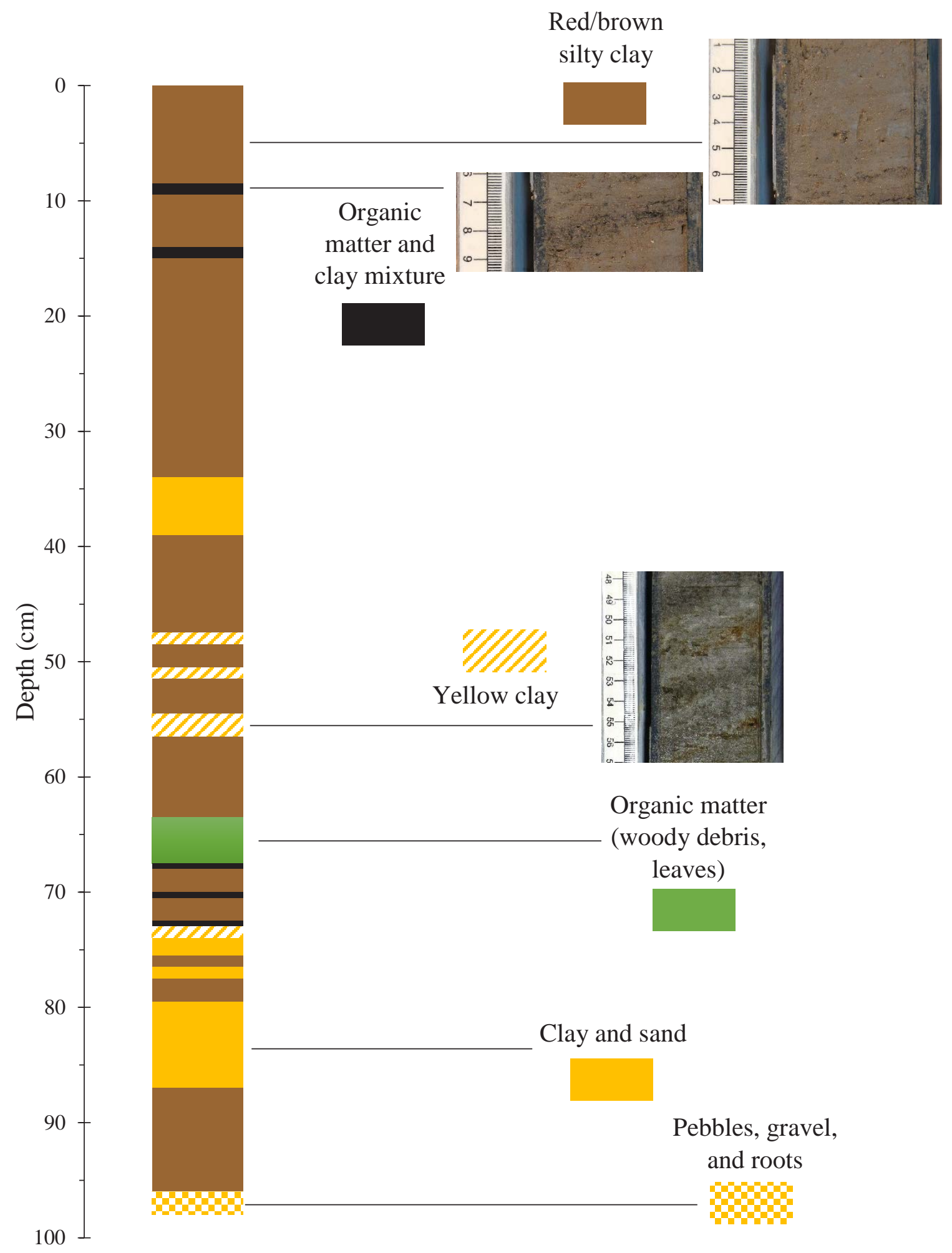

Figure 24. Detailed lithology description for core pro-delta Lake Butler core LB-16-C7. 

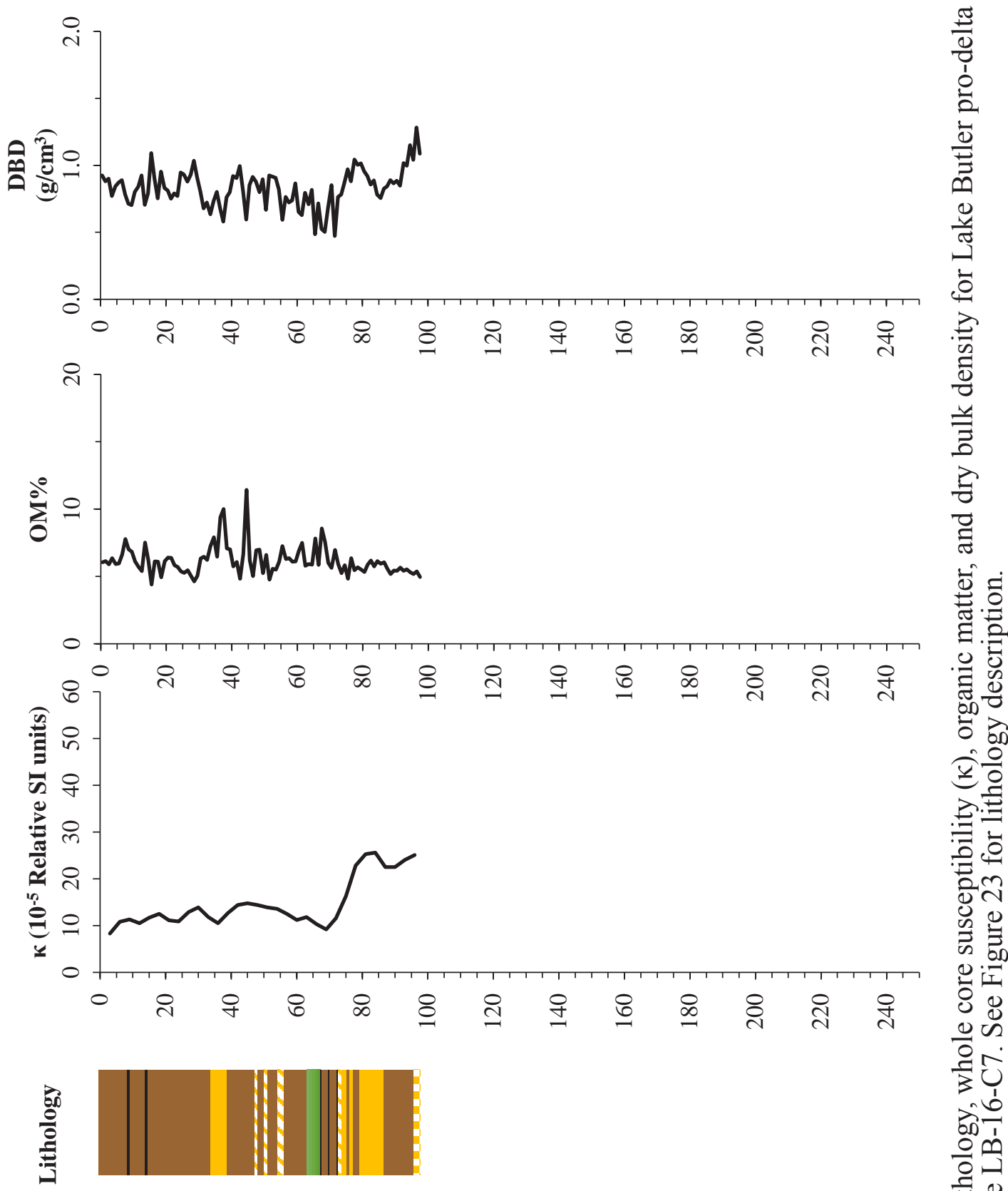

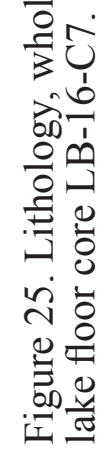


The pro-delta lake floor core (C7) is $98 \mathrm{~cm}$ long and can be divided into three sections: 98-74 cm, 74-34 cm, and 34-0 cm (Figures 24 and 25). From 98-74 cm, the lithology is composed of granules in the bottom $2 \mathrm{~cm}$ overlying red/brown clay, and sandy/clay layers. In this section, magnetic susceptibility is high organic matter content is uniform at 7\%. The dry bulk density decreases in the clay layers and increases in the sand. Between 74-34 cm core depth, there are woody debris, sand, and clay layers. The $\kappa$ remains uniform in this section, whereas, the organic matter content and dry bulk density display greater variations. In the uppermost $34 \mathrm{~cm}$, the lithology present is silty mud/ clay. The $\kappa$, organic matter content, and dry bulk density fluctuates, but are generally uniform in value.

\subsubsection{Shoreline Change}

To document changes in sediment deposition and shoreline progradation from 1994 to 2016, aerial photographs of the delta at the upstream end of Lake Butler were examined (Figures 26-30). Due to the varying lake level in Lake Butler, the water level on each

photograph was compared to the lake level in the year 2000 photograph. In 1994, Haskell Run enters Lake Butler on the left side of the valley. The lake level was higher in 1994 relative to the 2000 water line (Table 19). By 2000, Haskell Run enters Lake Butler on the right side of the valley. In the 2003 photo, it is difficult to see the water level due to the poor photo quality; however, it is known that the photograph was taken in July 2003, after a major regional flooding event (USGS, 2016b). Haskell Run continues to enter Lake Butler from the right side of the valley from 2005 to 2016. The lake level increases in 2005 then drops in 2006, possibly due to the time of the year (early spring) rather than due to flooding. In 2010, although lake level is low, the C4 core site is now clearly on the delta top environment. Since 2010, lake level is lower than in the years prior to 2010. 

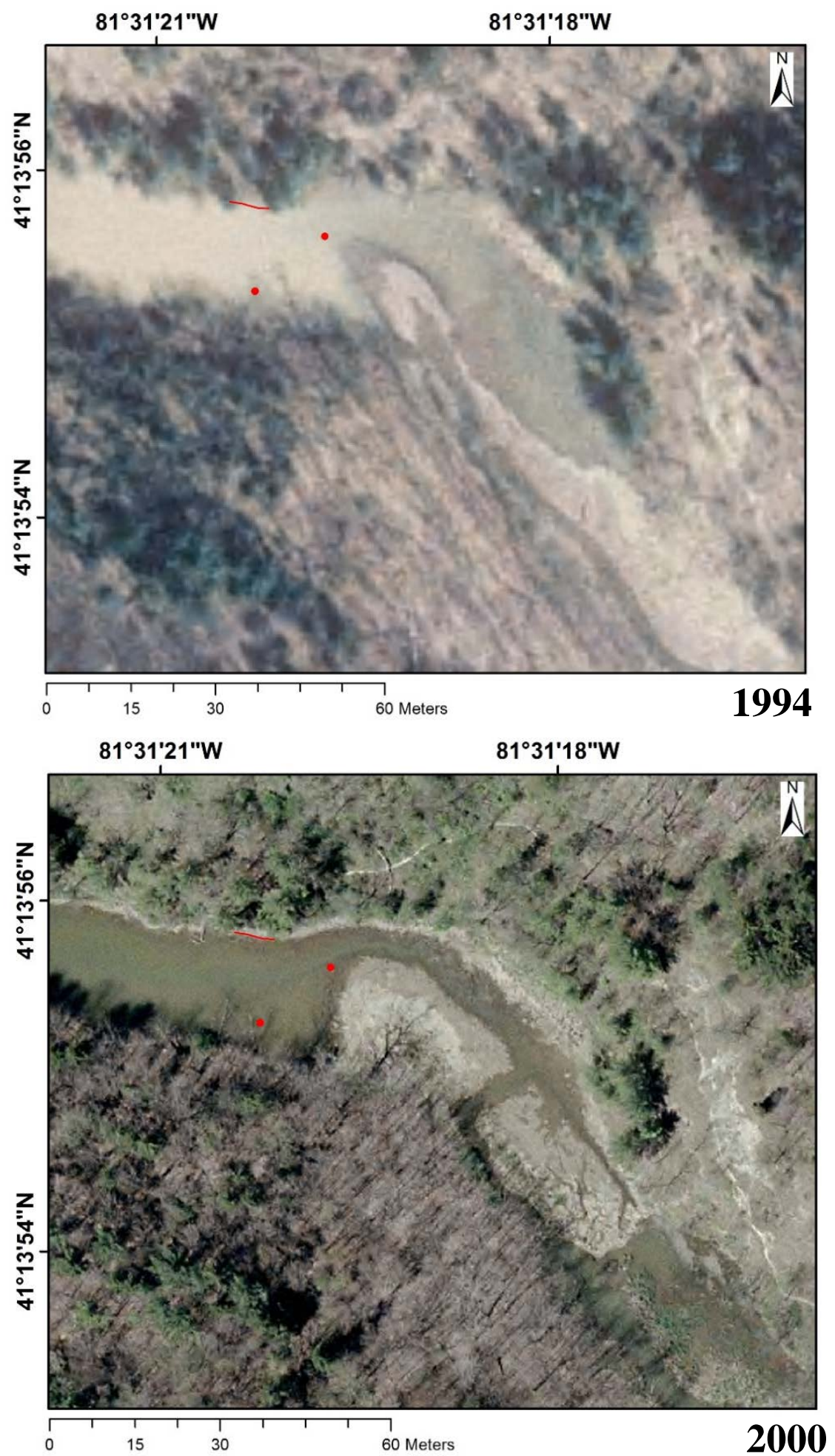

Figure 26. Haskell Run and the Lake Butler delta in 1994 and 2000. The rightmost red dot is the LB-16-C4 core location and the leftmost dot is the LB-16-C1 core location. The red line feature is the year 2000 shoreline reference point to determine relative water level change (Summit County Fiscal Office, 2016). 

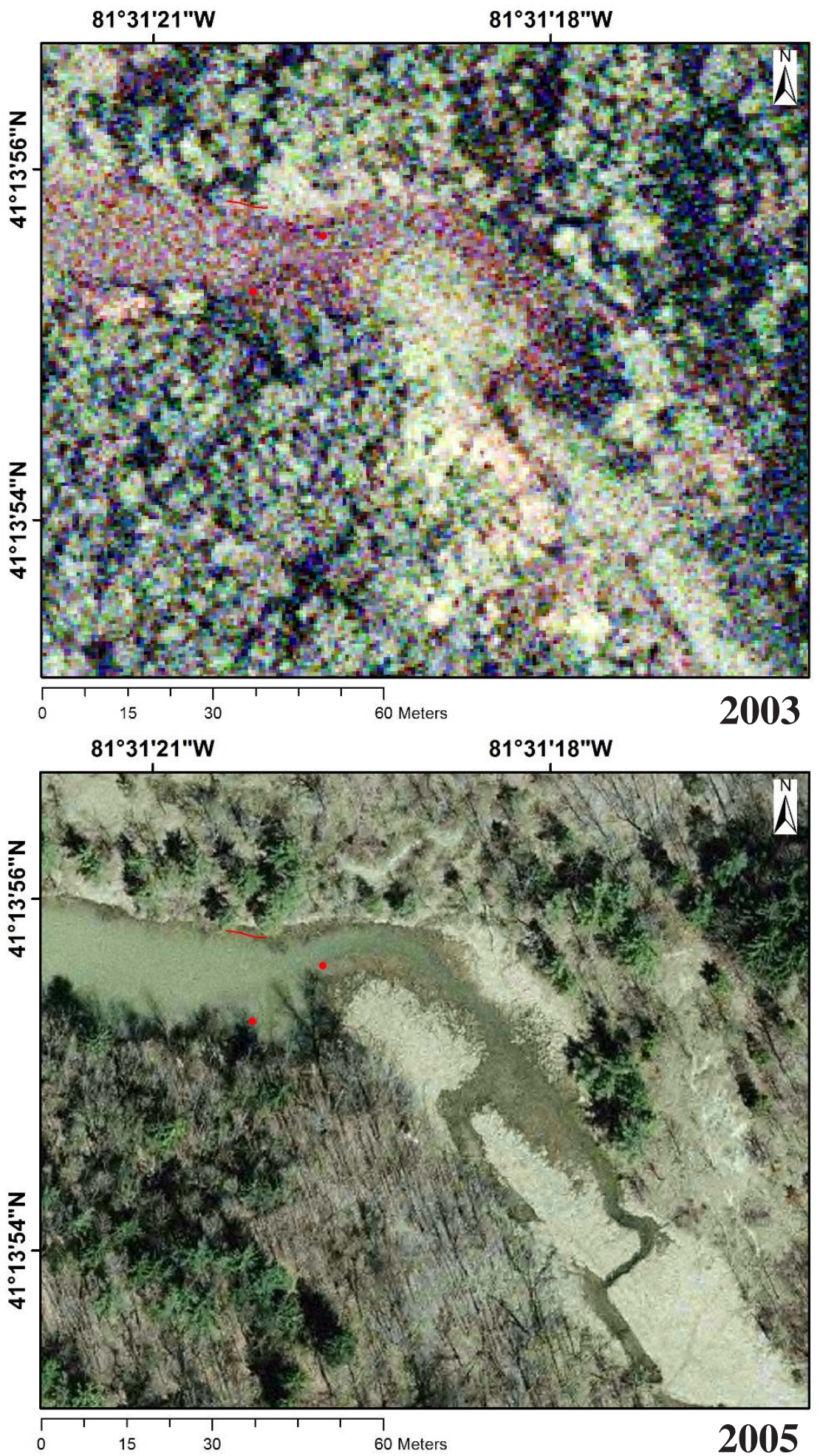

Figure 27. Haskell Run and the Lake Butler delta in 2003 and 2005. The rightmost red dot is the LB-16-C4 core location and the leftmost dot is the LB-16-C1 core location. The red line feature is the year 2000 shoreline reference point to determine relative water level change (Summit County Fiscal Office, 2016; USGS, 2016b). 

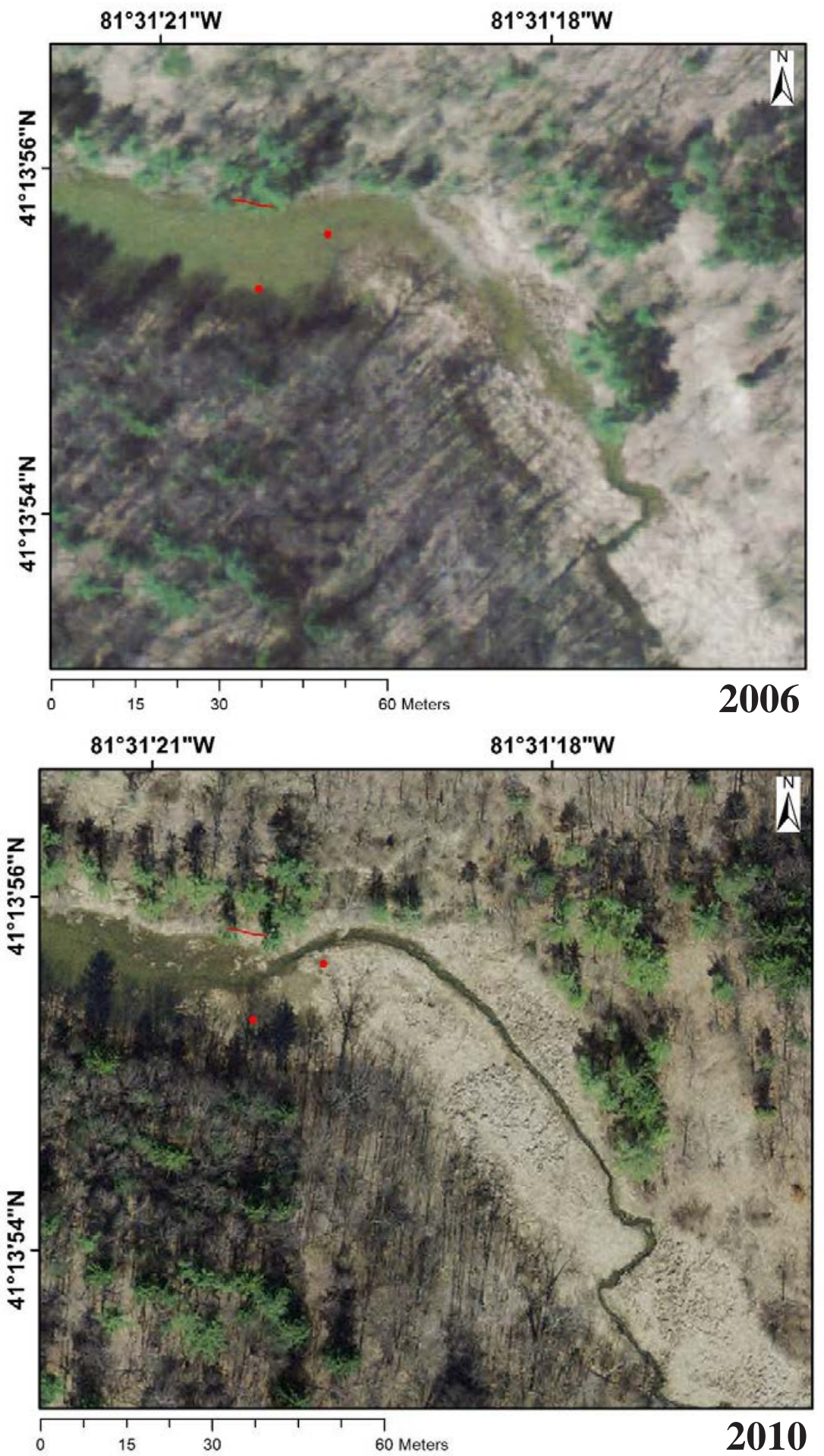

Figure 28. Haskell Run and the Lake Butler delta in 2006 and 2010. The rightmost red dot is the LB-16-C4 core location and the leftmost dot is the LB-16-C1 core location. The red line feature is the year 2000 shoreline reference point to determine relative water level change (Summit County Fiscal Office, 2016). 

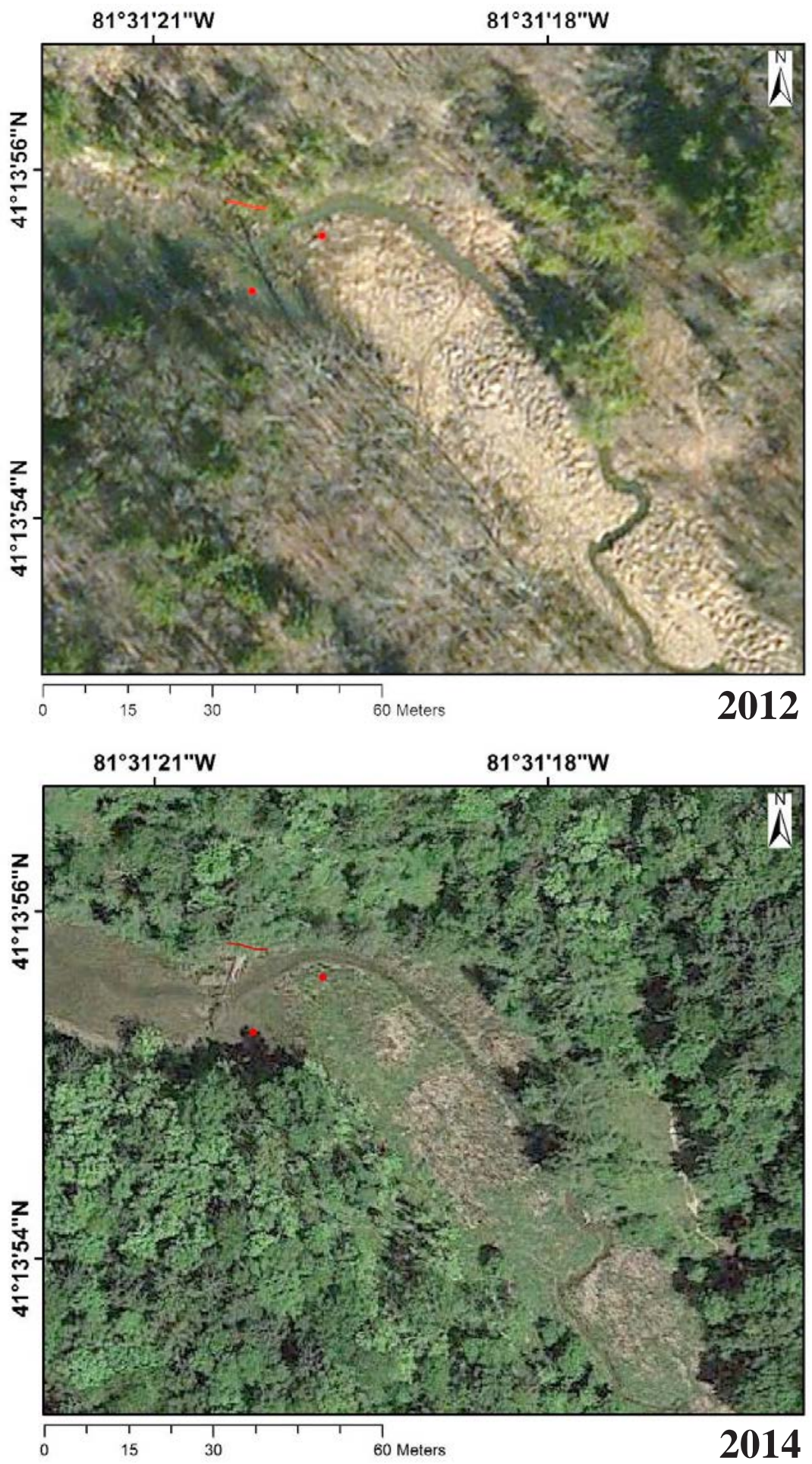

Figure 29. Haskell Run and the Lake Butler delta in 2012 and 2014. The rightmost red dot is the LB-16-C4 core location and the leftmost dot is the LB-16-C1 core location. The red line feature is the year 2000 shoreline reference point to determine relative water level change (Google, 2016; Summit County Fiscal Office, 2016). 

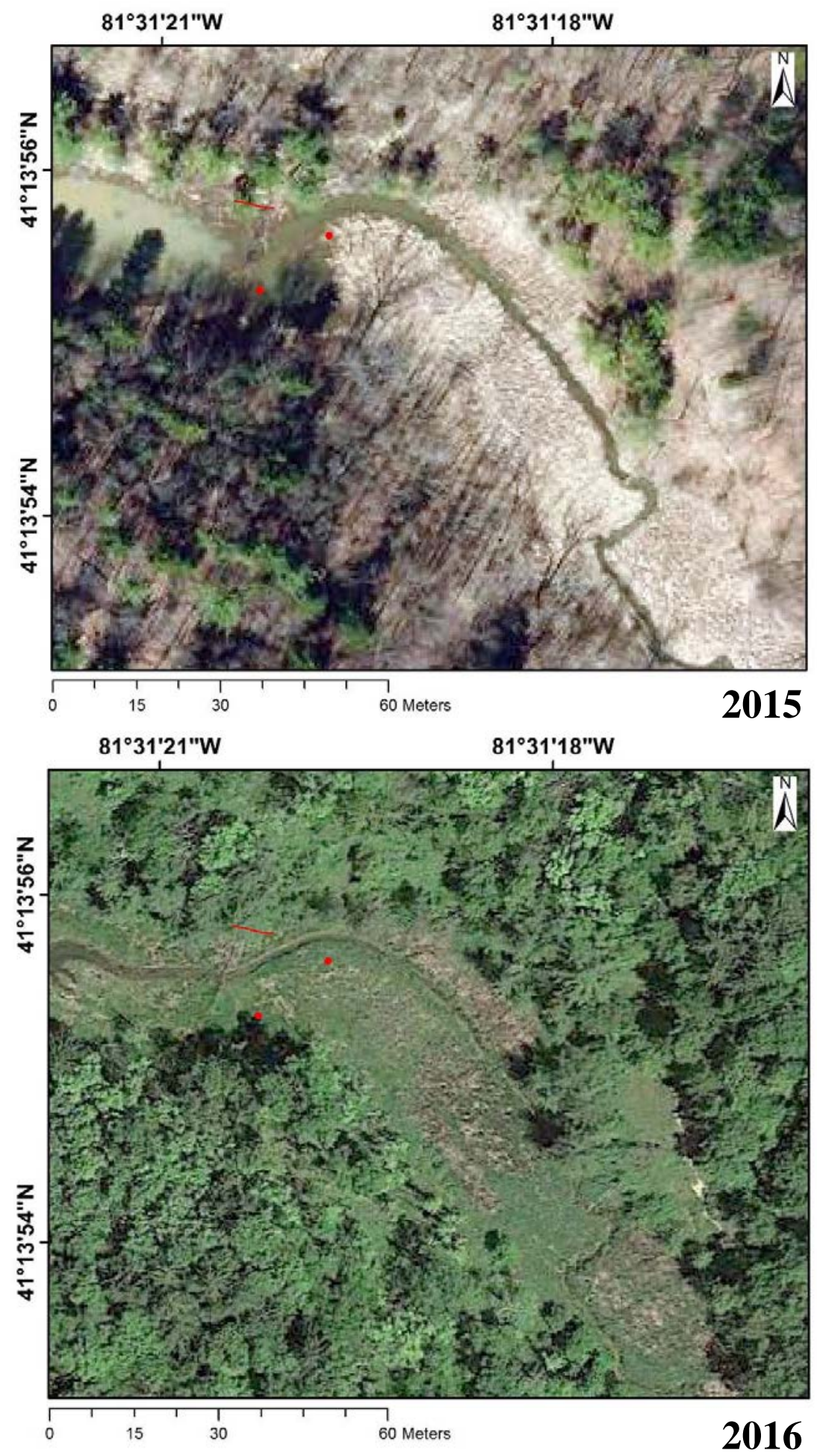

Figure 30. Haskell Run and the Lake Butler delta in 2015 and 2016. The rightmost red dot is the LB-16-C4 core location and the leftmost dot is the LB-16-C1 core location. The red line feature is the year 2000 shoreline reference point to determine relative water level change (Google, 2016; Summit County Parcel Viewer, 2016). 
Table 19. Lake Butler lake level relative to the year 2000 water level.

\begin{tabular}{cc}
\hline \hline Year & Water Level \\
\hline 1994 & Deeper \\
2000 & Reference year \\
2003 & Same/ Slightly deeper \\
2005 & Deeper \\
2006 & Same \\
2010 & Shallower \\
2012 & Shallower \\
2014 & Shallower \\
2015 & Similar \\
2016 & Shallower \\
\hline
\end{tabular}




\subsubsection{Land cover}

Land cover classification for this study was divided into four main categories: developed, farmland, undeveloped, and open water. Quantifying undeveloped and developed land cover change over time was the focus for land cover analysis. However, assessing changes in farmland is also important for watershed health and determining what pollutants or sediments are entering the watershed (Shi et al., 2017). Land cover area, land cover area change, impervious cover, and impervious cover change were tabulated for Lake Butler for five different years (Figure 31; Table 20; Appendix E). The total area of the Haskell Run watershed is 2,881,800 m². From 1985-2010, there was an overall $1.37 \%$ increase $\left(+39,600 \mathrm{~m}^{2}\right)$ in developed land, $0.87 \%$ decrease $\left(-25,200 \mathrm{~m}^{2}\right)$ in farmland, and $0.50 \%$ decrease $\left(-14,400 \mathrm{~m}^{2}\right)$ of undeveloped land. The greatest amount of change during 1985-2010 period occurred between 1996-2001 (Table 20). From 19852010, the overall increase in impervious surfaces was $12,712 \mathrm{~m}^{2}(0.44 \%)$. The majority of the land use change was converting farmland and undeveloped land into developed land. The change occurred at the eastern edge of the Haskell Run watershed by Akron Cleveland Road. The location of this change is also outside the Cuyahoga Valley National Park boundaries.

\subsection{Lake Litchfield}

Surficial and core sediment properties were determined from Lake Litchfield. Lake Litchfield delta shorelines from 1994 to 2016 were assessed. Land cover changes were quantified for the Ritchie Run watershed between 1985 and 2010.

\subsubsection{Surface Samples}

Thirteen surface samples were collected from the Lake Litchfield impoundment (Table 24). The impoundment samples consisted largely of tan clay overlying an organic 

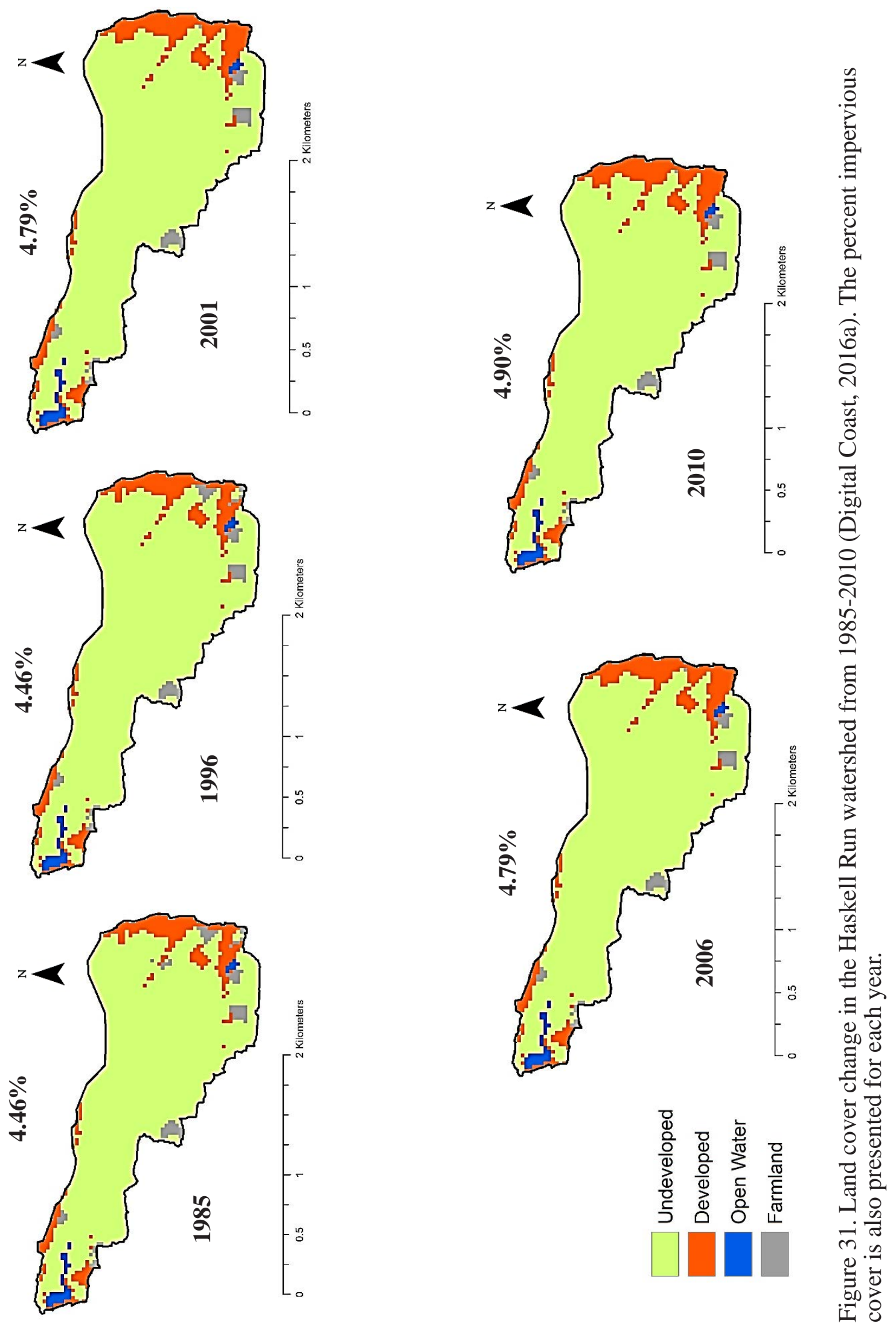


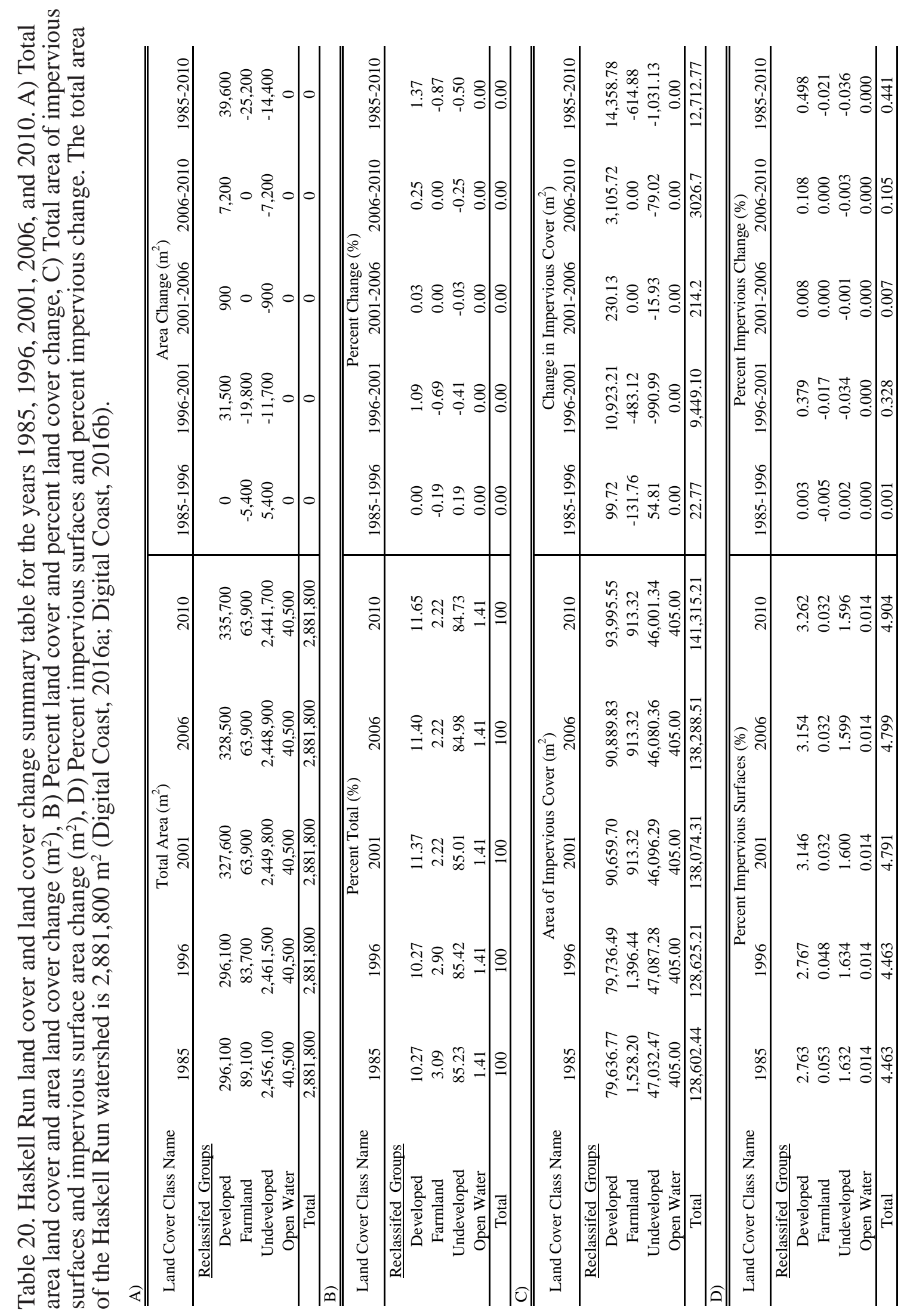




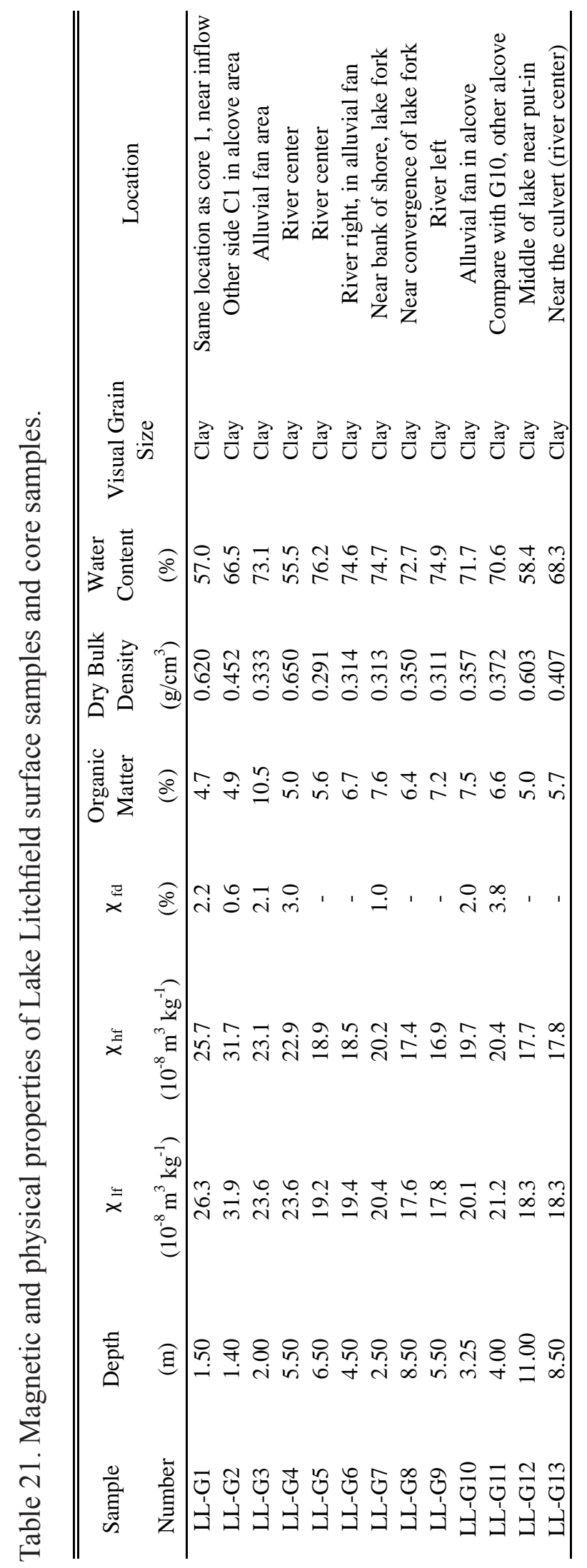


Table 22. Heavy metal concentrations for selected Lake Litchfield sediment samples.

\begin{tabular}{ccccc}
\hline \hline Sample & $\begin{array}{c}\mathrm{Pb} \\
\text { Concentration } \\
(\mu \mathrm{g} / \mathrm{g})\end{array}$ & $\begin{array}{c}\mathrm{Zn} \\
\text { Concentration } \\
(\mu \mathrm{g} / \mathrm{g})\end{array}$ & $\begin{array}{c}\mathrm{Cu} \\
\text { Concentration } \\
(\mu \mathrm{g} / \mathrm{g})\end{array}$ & $\begin{array}{c}\mathrm{Cr} \\
\text { Concentration } \\
(\mu \mathrm{g} / \mathrm{g})\end{array}$ \\
\hline Surface & & & & 52.3 \\
LL-G1 & 19.9 & 88.5 & 24.0 & 51.7 \\
LL-G1 Rep & 21.3 & 92.0 & 22.8 & 44.8 \\
LL-G2 & 20.4 & 79.3 & 15.8 & 84.8 \\
LL-G8 & 21.1 & 126.6 & 29.1 & \\
Core & & & & 44.7 \\
LL-C1 2cm & 16.3 & 90.5 & 24.4 & 55.7 \\
LL-C1 30cm & 33.4 & 100.5 & 32.9 & 53.4 \\
LL-C1 60cm & 24.6 & 104.4 & 28.8 & 45.3 \\
LL-C1 90cm & 22.7 & 84.7 & 20.7 & 42.3 \\
LL-C1 120cm & 10.5 & 68.5 & 24.5 & \\
\hline
\end{tabular}


black mud; however, samples G5,6,7 had a distinctive red color. Samples were evaluated for porosity, organic matter content, dry bulk density, mass-corrected susceptibility $(\chi)$, visual grain size, heavy metal concentrations, and magnetic properties (Tables 21 and 22). These clay-rich samples had porosities between 55.5-76\%, low organic matter between $4.9-10.5 \%$, and low bulk densities ranged from $0.290-0.630 \mathrm{~g} / \mathrm{cm}^{3}$. Magnetic susceptibility ranged between $17.6-31.710^{-8} \mathrm{~m}^{3} \mathrm{~kg}^{-1}$.

Surficial samples G1,2, and 8 were analyzed for heavy metal concentrations (Table 25). The average metal concentrations were: $\mathrm{Pb}=21 \mu \mathrm{g} / \mathrm{g}, \mathrm{Zn}=97 \mu \mathrm{g} / \mathrm{g}, \mathrm{Cu}=23 \mu \mathrm{g} / \mathrm{g}$, and $\mathrm{Cr}=58 \mu \mathrm{g} / \mathrm{g}$. G8 had a high $\mathrm{Zn}$ concentration of $127 \mu \mathrm{g} / \mathrm{g}$. These samples were also tested for magnetic properties including ferrimagnetic concentration, magnetic grain size, and mineralogy (Appendix C). The SIRM for these samples is on average $2,20010^{-6} \mathrm{~m}^{3} \mathrm{~kg}^{-1}$, the average $\chi_{\mathrm{ff}}$ is $25.310^{-8} \mathrm{~m}^{3} \mathrm{~kg}^{-1}$, and the average $\chi \mathrm{ARM}$ is $0.910^{-}$ ${ }^{6} \mathrm{~m}^{3} \mathrm{~kg}^{-1}$. The S-ratio for the samples were at or about 0.9 , indicating a mixture of high and low coercivity minerals are present. Most of these surficial samples had frequency dependence at or above $2 \%$ indicating the presence of SPM grains.

\subsubsection{Sediment Cores}

Four sediment cores were collected from Lake Litchfield in May 2016. One core was extracted from the delta slope (LL-16-C1), and the remaining cores were collected from the subaqueous levee where Ritchie Run enters Lake Litchfield (Figure 15).

The delta slope core, LL-16-C1, is $138 \mathrm{~cm}$ long and can be divided into three main sections: 138-118 cm, 118-78 cm, and 78-0 cm (Figures 32 and 33). Between 138-118 cm core depth, the lithology is a yellow/brown medium sand. There is a general decreasing trend up core in the whole-core susceptibility and dry bulk density profiles, and a slight increase in the organic matter content (Figure 33). Between 118-78 cm core depth, there are three lithologies present: clay, sand, and silty mud. In the clay layers, $\kappa$ and dry bulk 


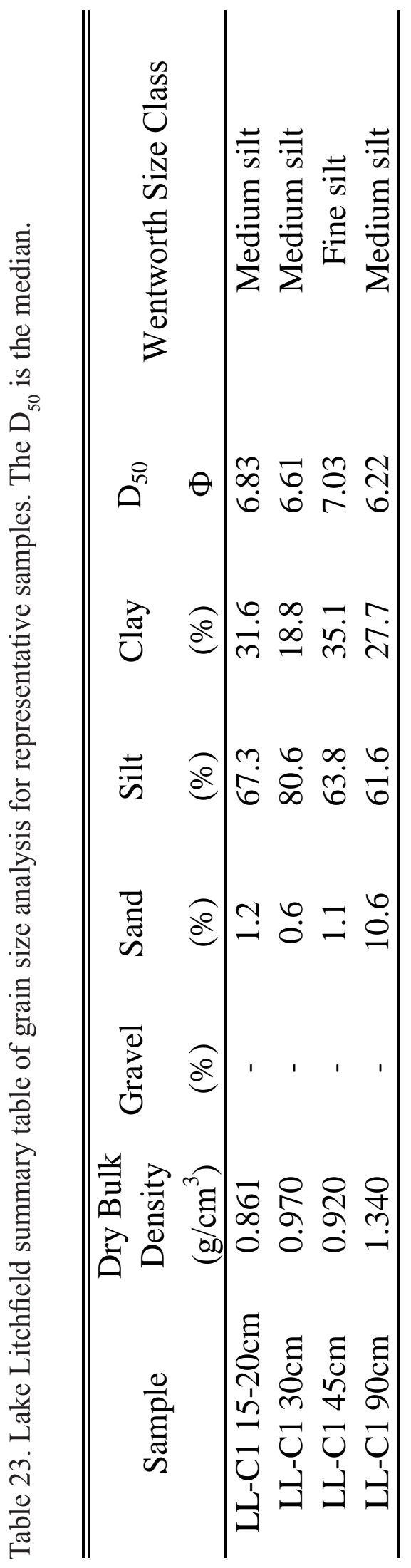




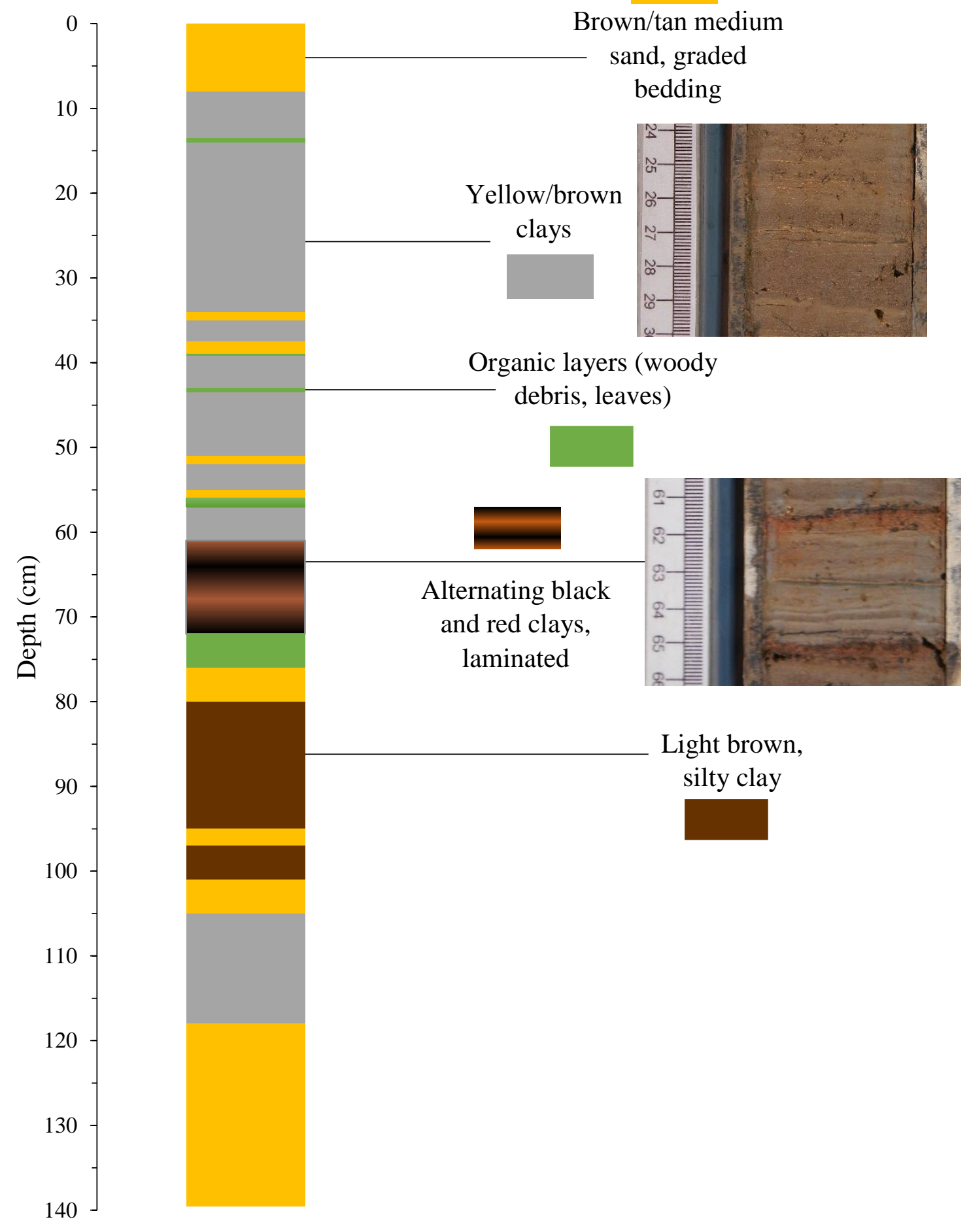

Figure 32. Detailed lithology description for Lake Litchfield pro-delta core LL-16-C1. 

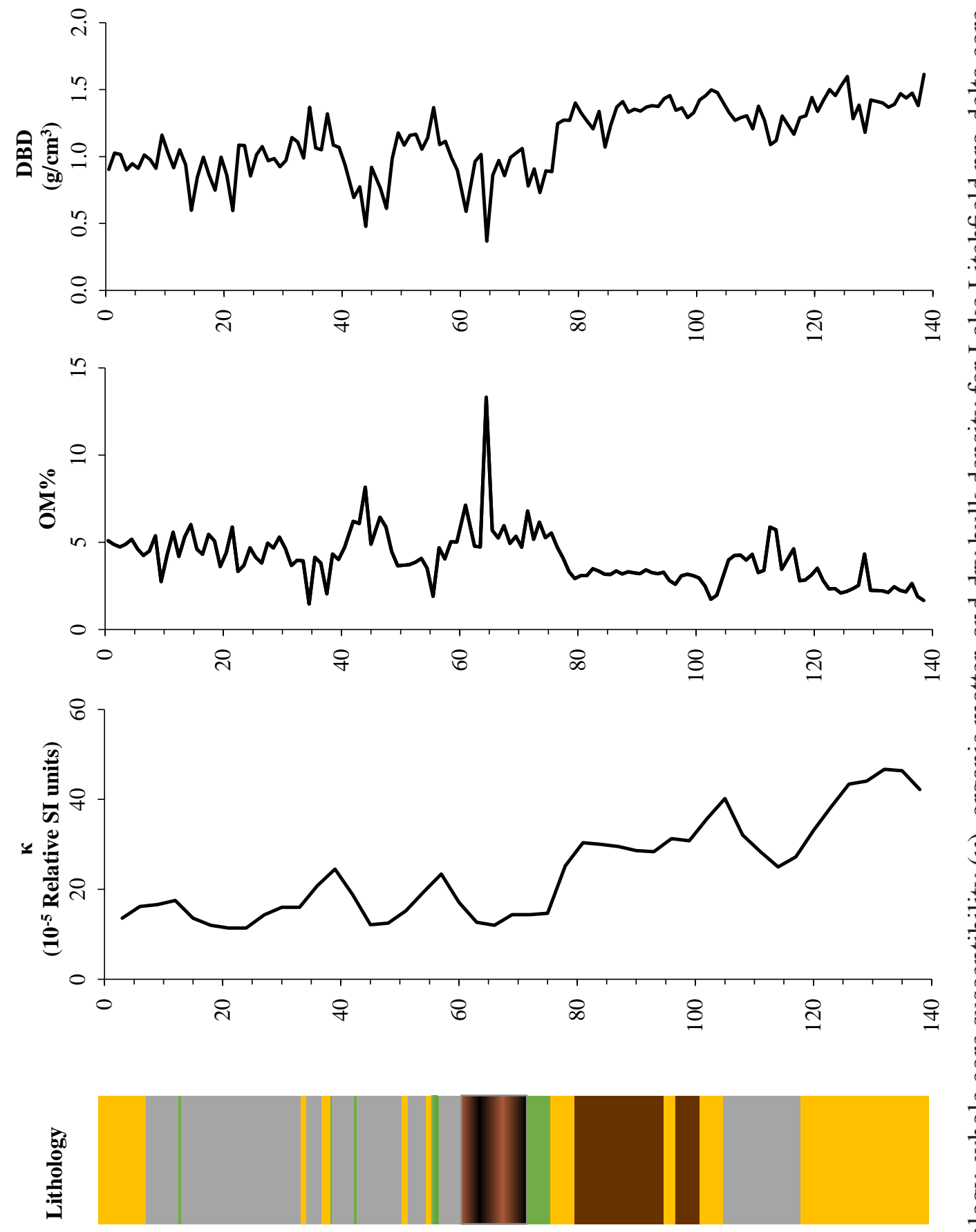

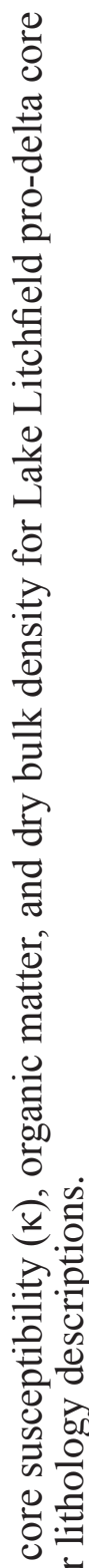

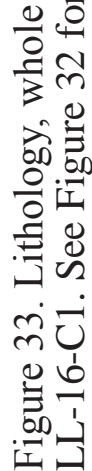



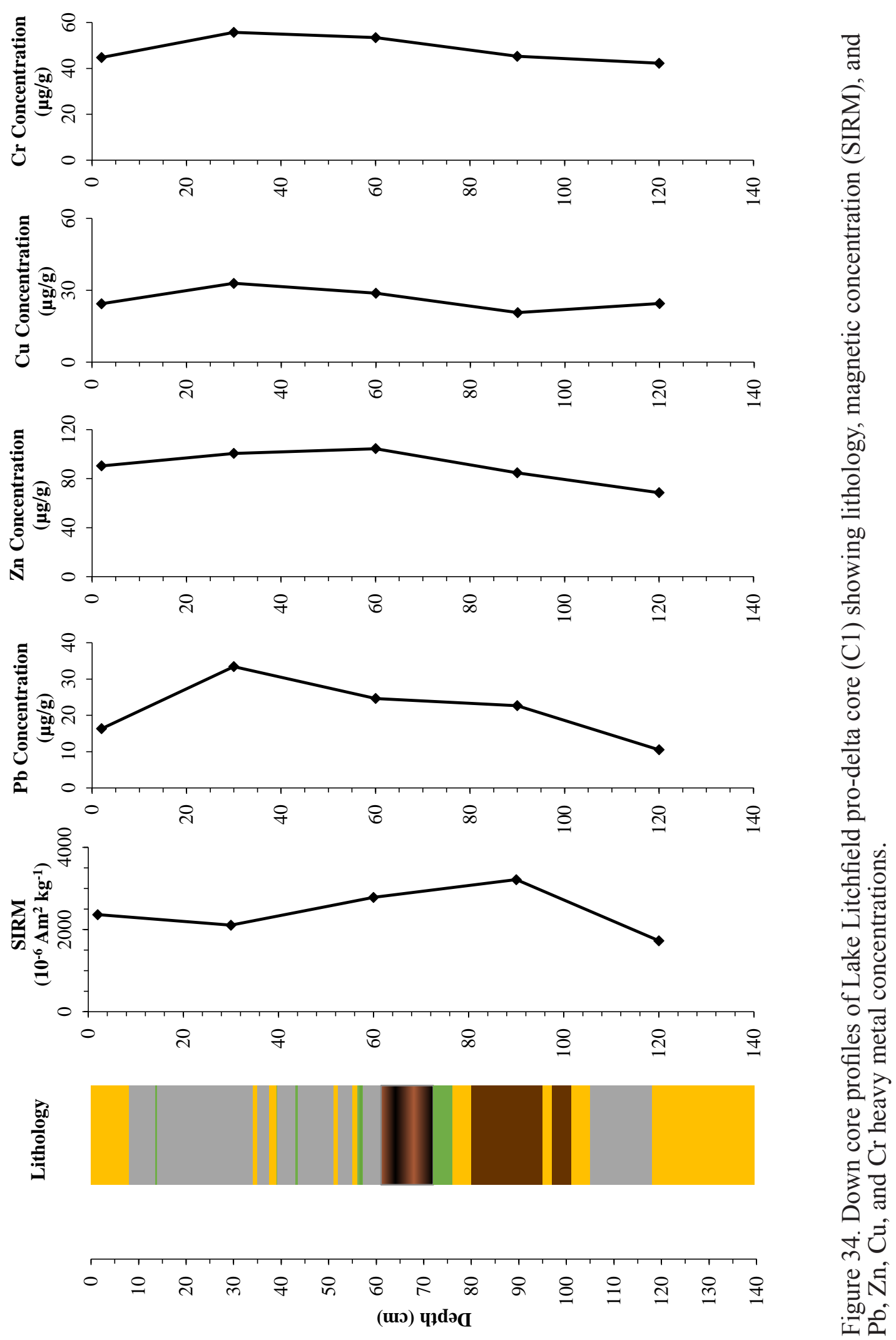

$$
\text { (uכ) प1dәव }
$$




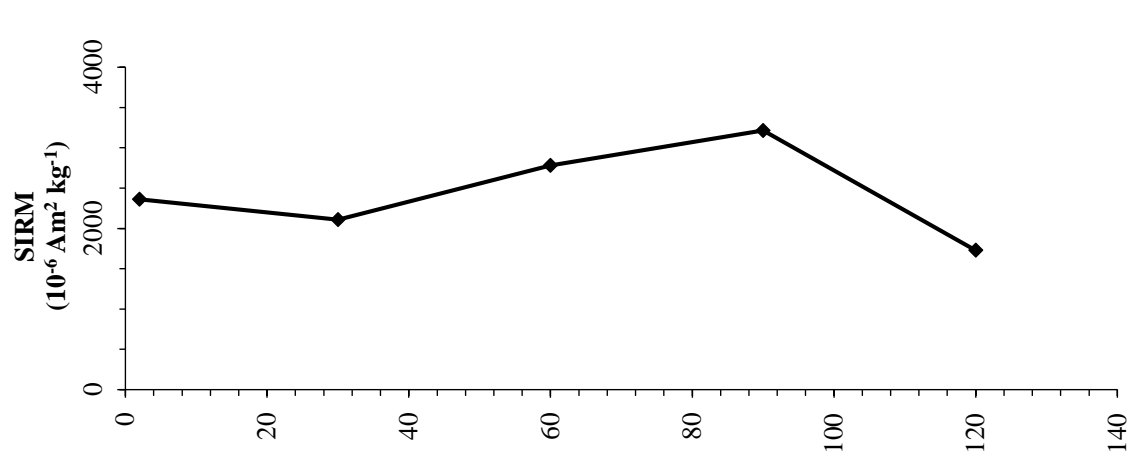

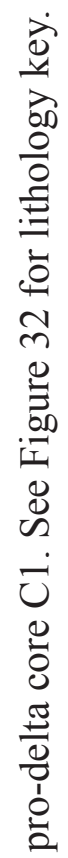
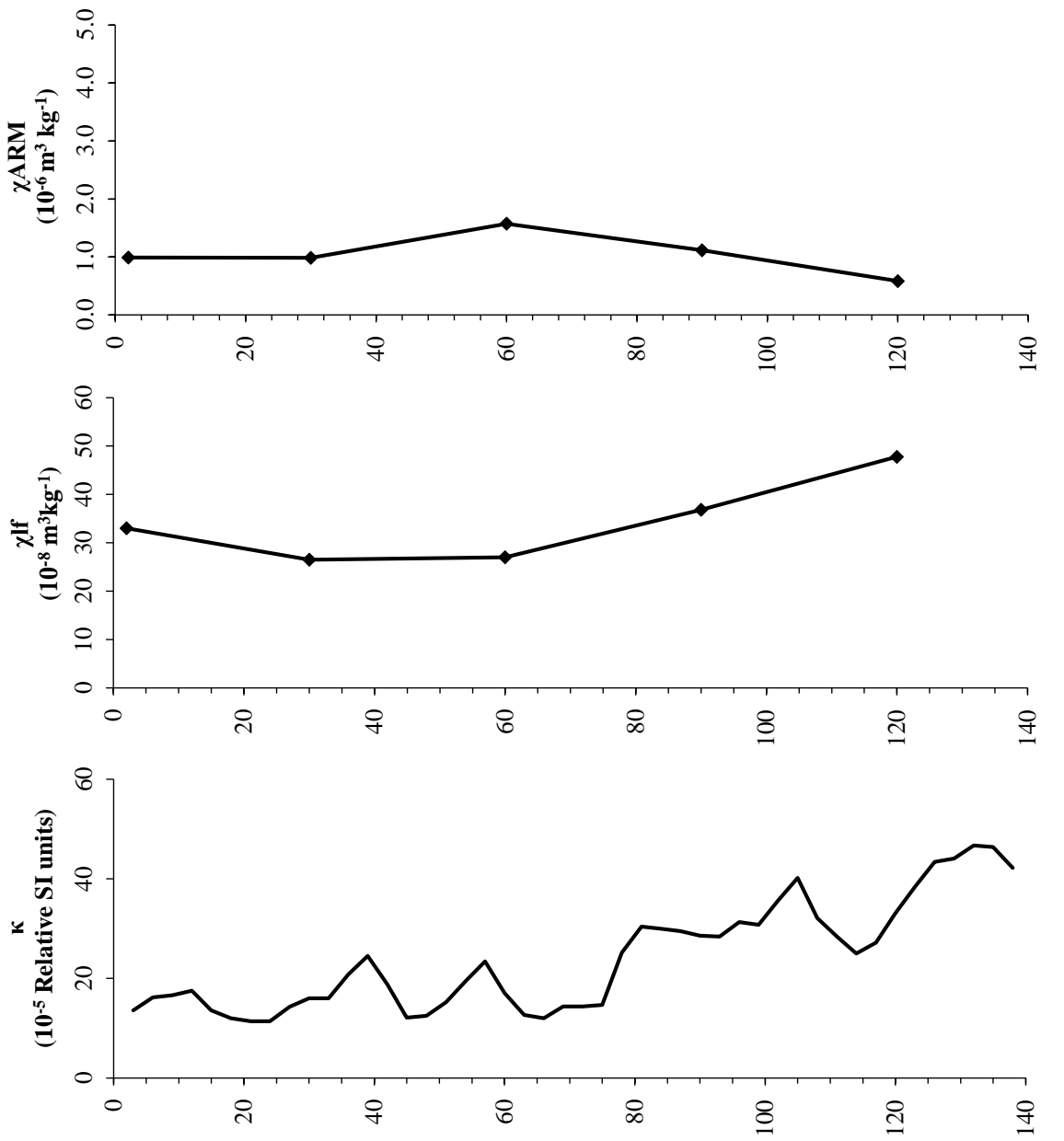

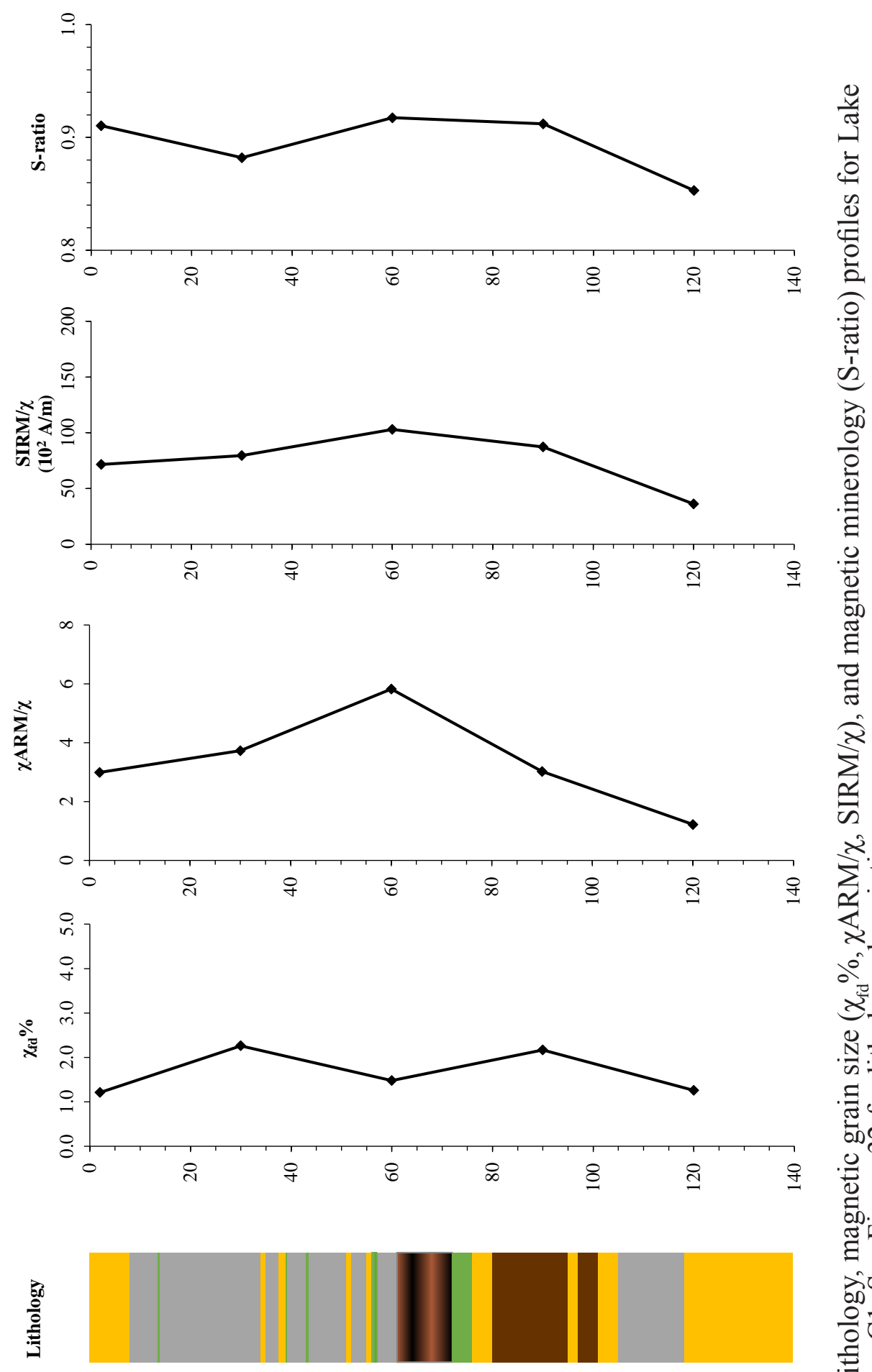

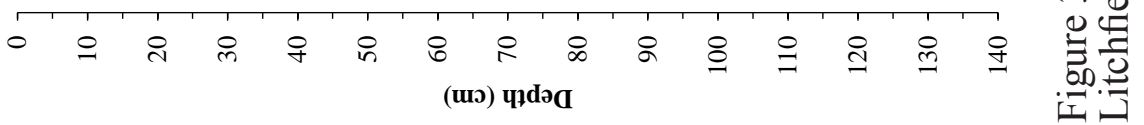




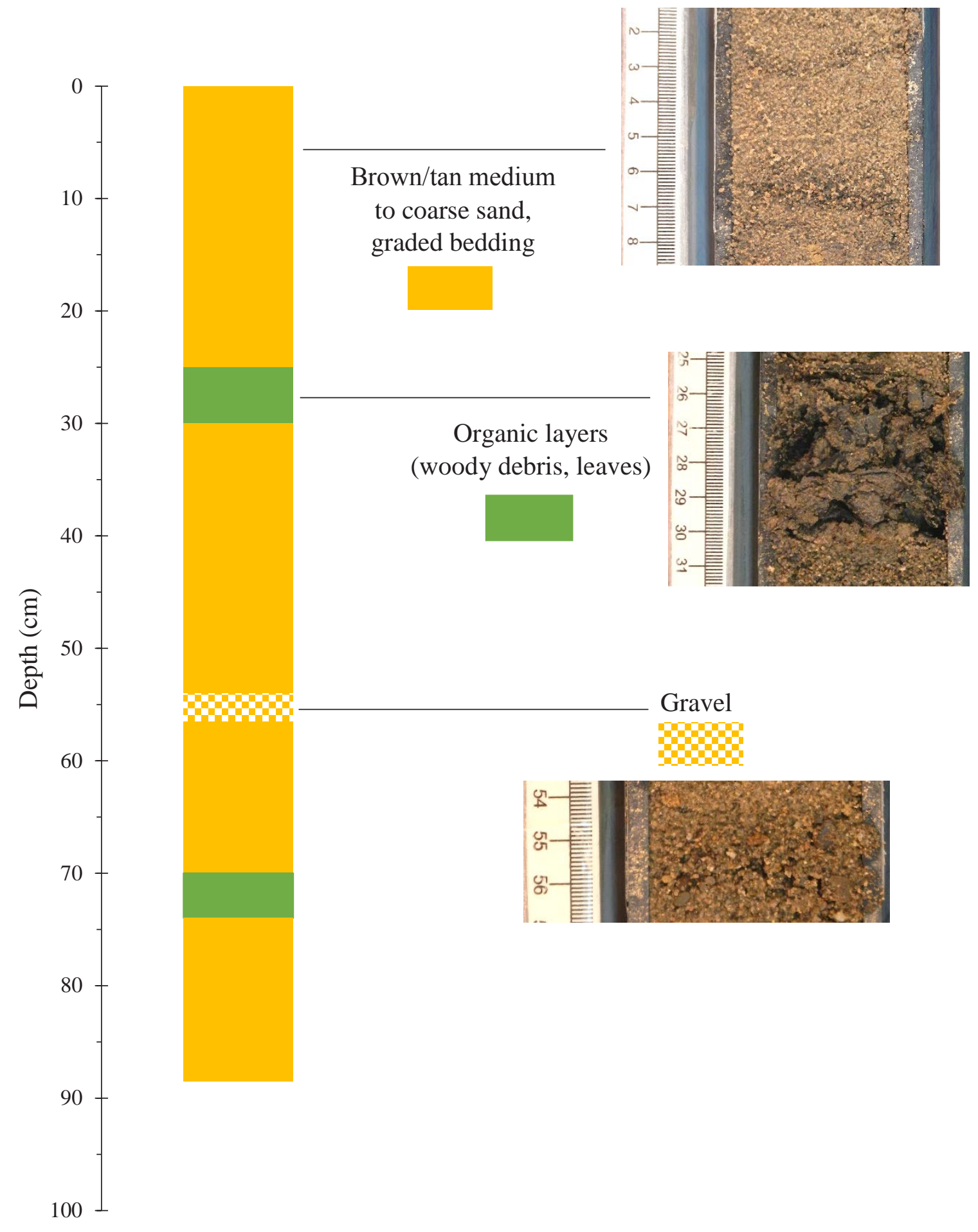

Figure 37. Detailed lithology description for Lake Litchfield sediment core LL-16-C2. 

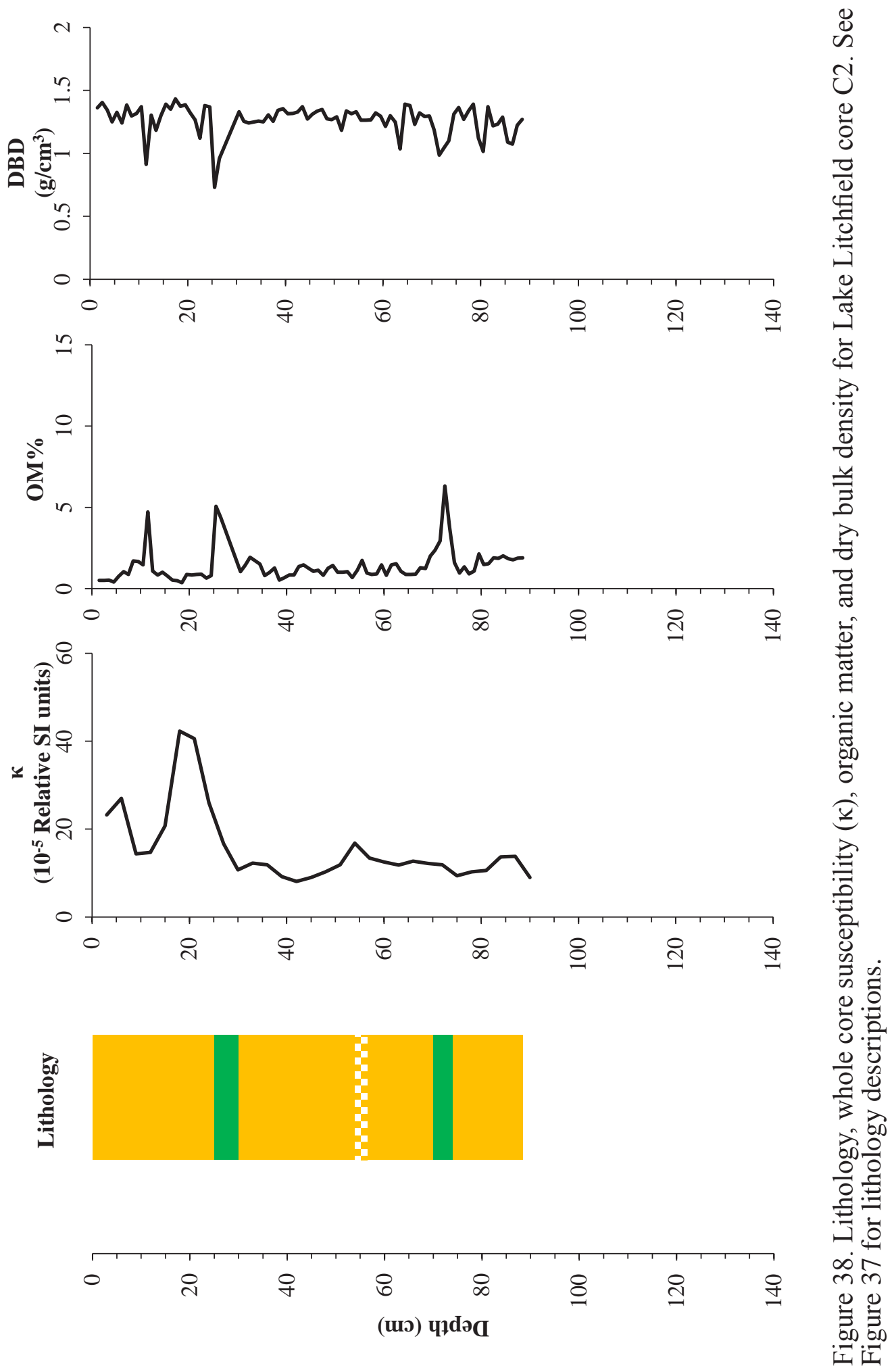

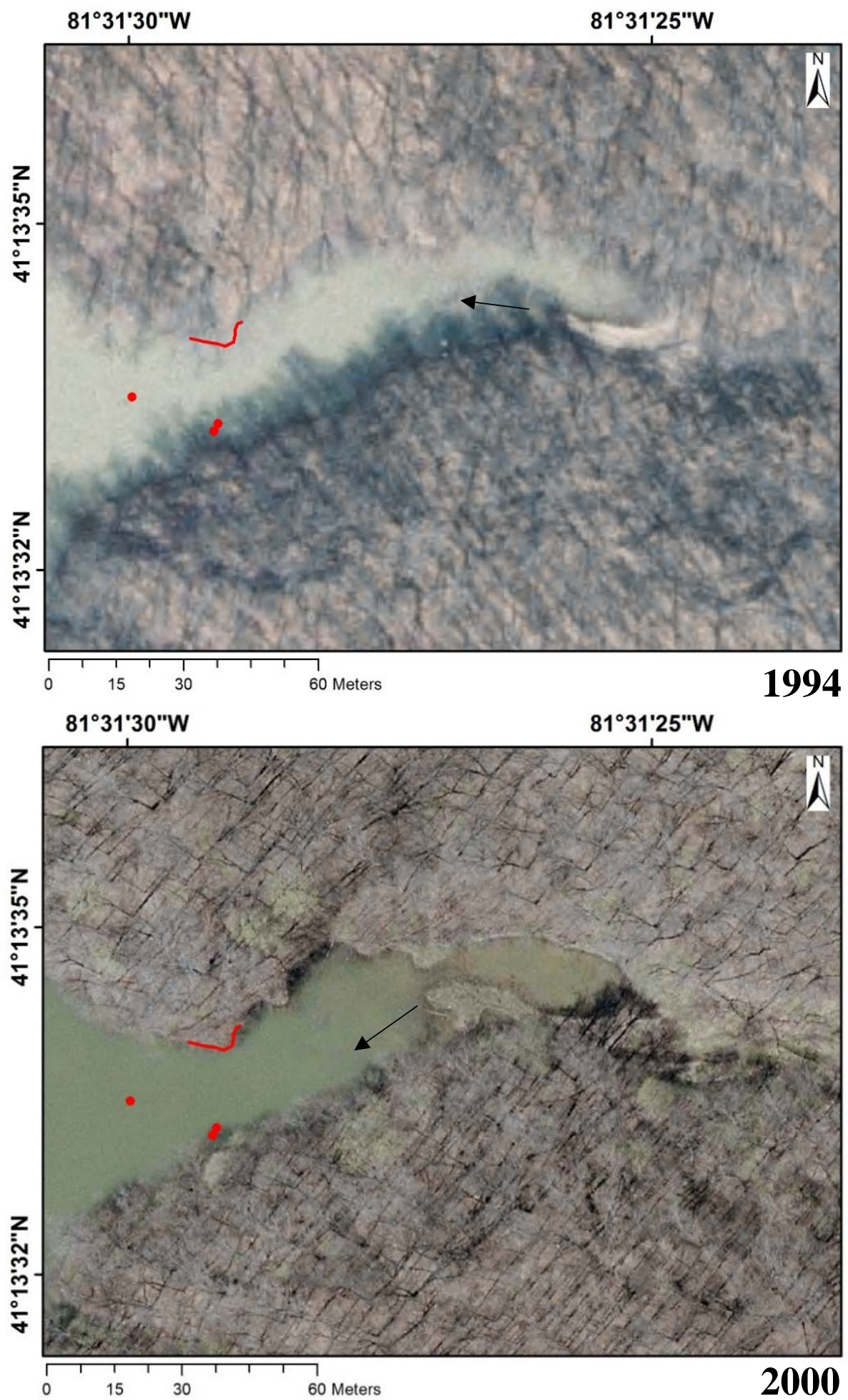

Figure 39. Lake Litchfield delta in 1994 and 2000. The leftmost dot is core LL-16-C1 and the rightmost dots are cores LL-16-C2 and C3 at the subaqueous delta. The red line is the year 2000 shoreline reference to determine relative water level change. Arrow shows delta progradation (Summit County Fiscal Office, 2016). 

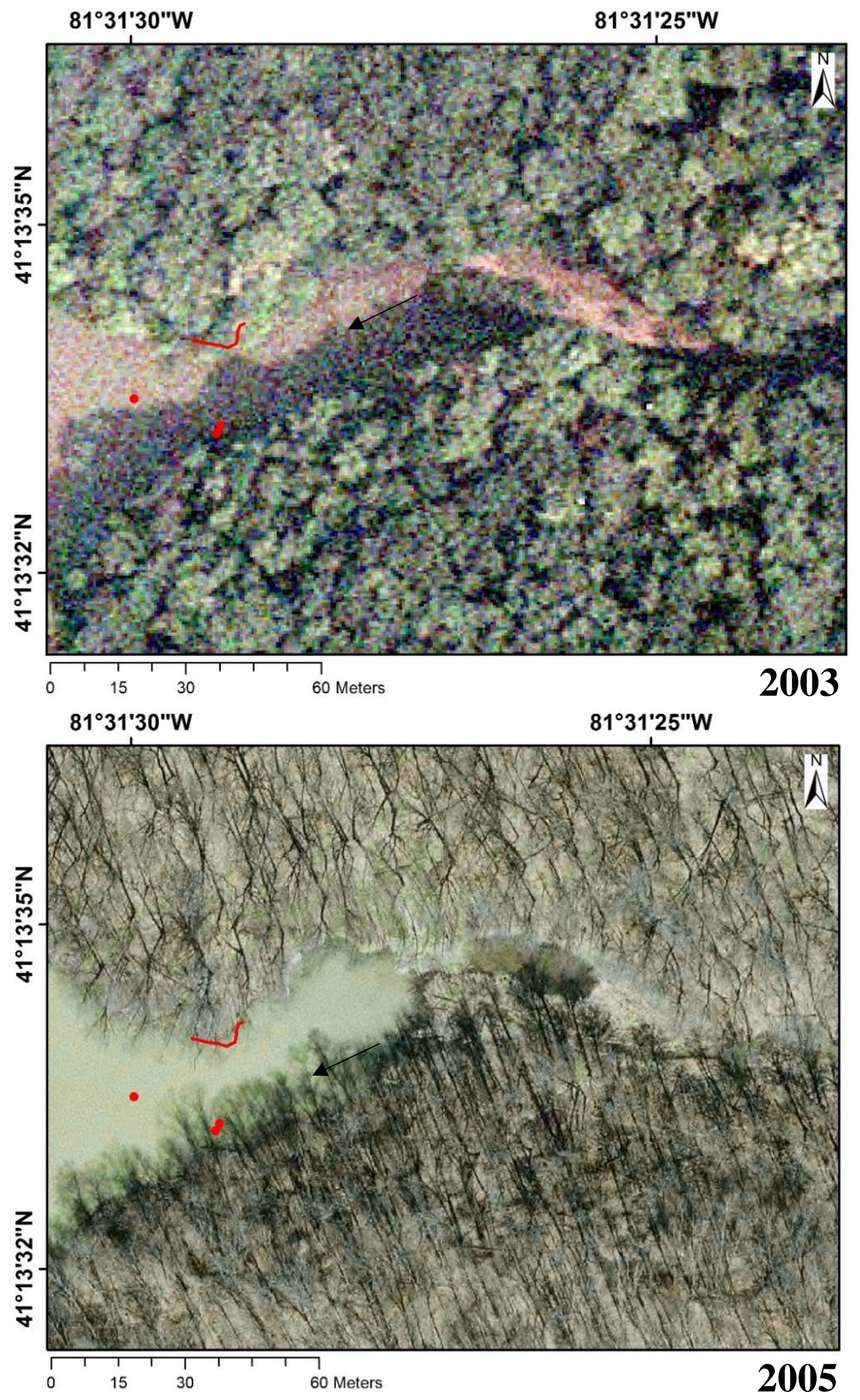

Figure 40. Lake Litchfield delta in 2003 and 2005. The leftmost dot is core LL-16-C1 and the rightmost dots are cores LL-16-C2 and C3 at the subaqueous delta. The red line is the year 2000 shoreline reference to determine relative water level change. Arrow shows delta progradation (Summit County Fiscal Office, 2016; USGS, 2016b). 

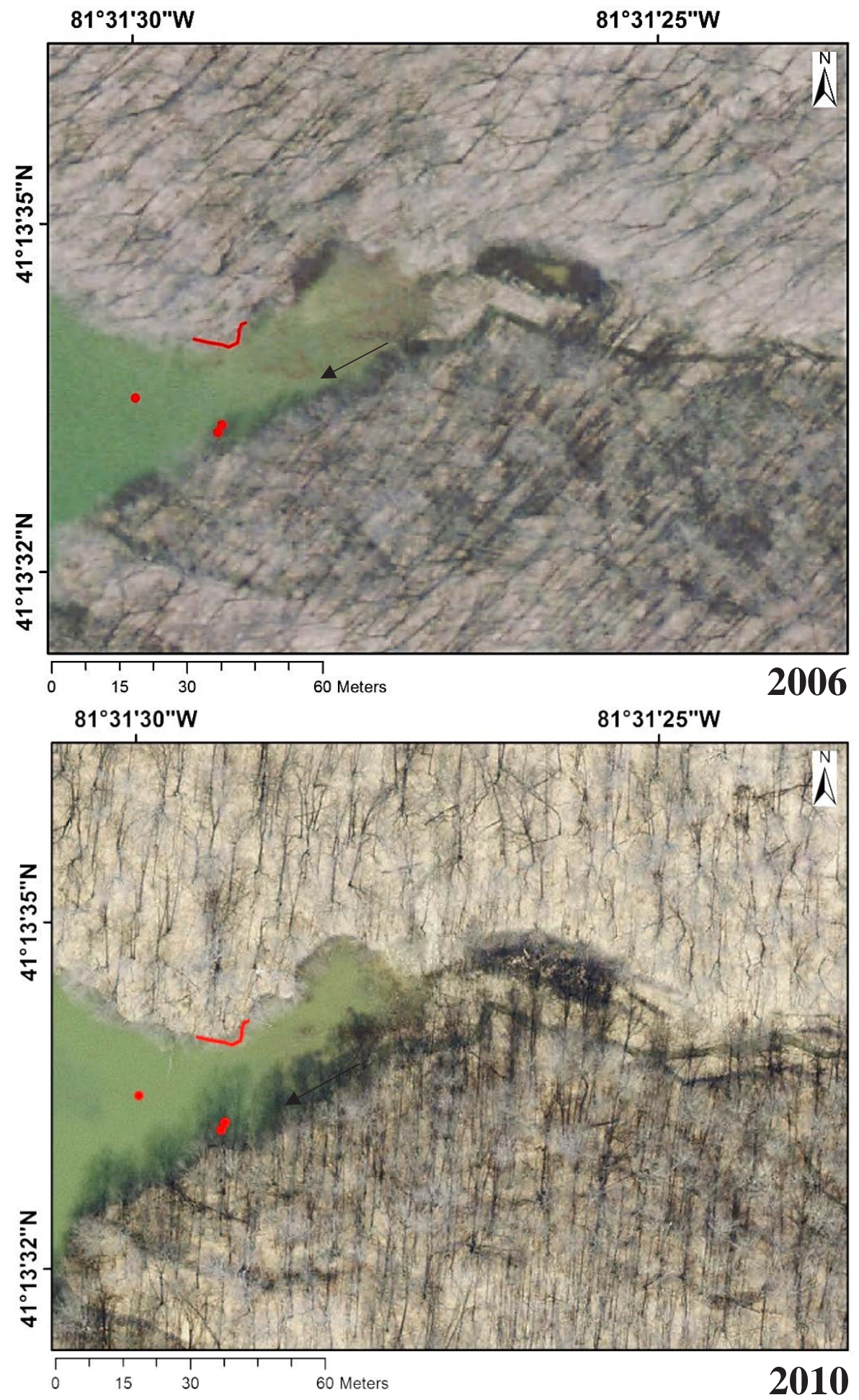

Figure 41. Lake Litchfield delta in 2006 and 2010. The leftmost dot is core LL-16-C1 and the rightmost dots are cores LL-16-C2 and C3 at the subaqueous delta. The red line is the year 2000 shoreline reference to determine relative water level change. Arrow shows delta progradation (Summit County Fiscal Office, 2016). 

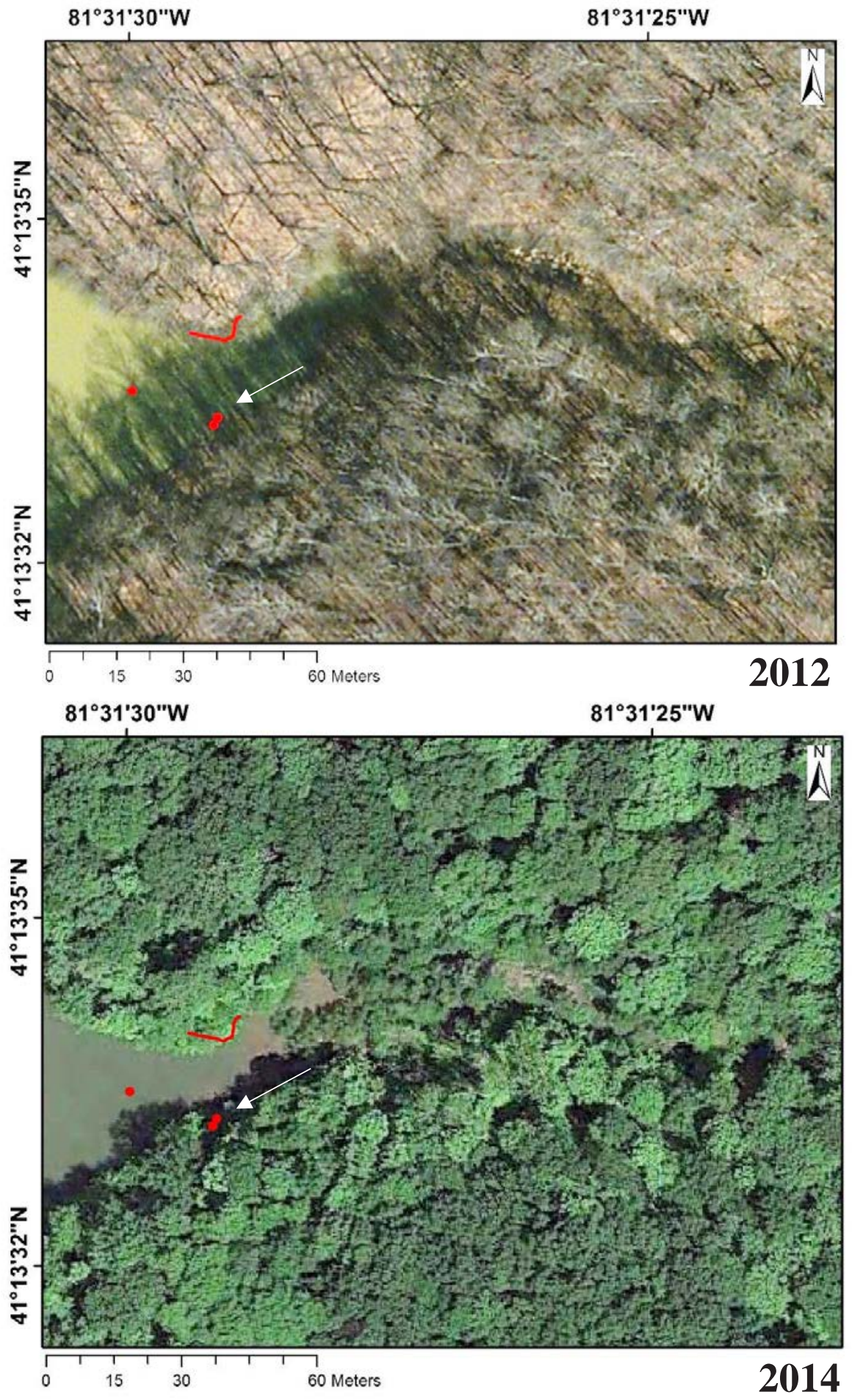

Figure 42. Lake Litchfield delta in 2012 and 2014. The leftmost dot is core LL-16-C1 and the rightmost dots are cores LL-16-C2 and C3 at the subaqueous delta. The red line is the year 2000 shoreline reference to determine relative water level change. Arrow shows delta progradation (Summit County Fiscal Office, 2016). 

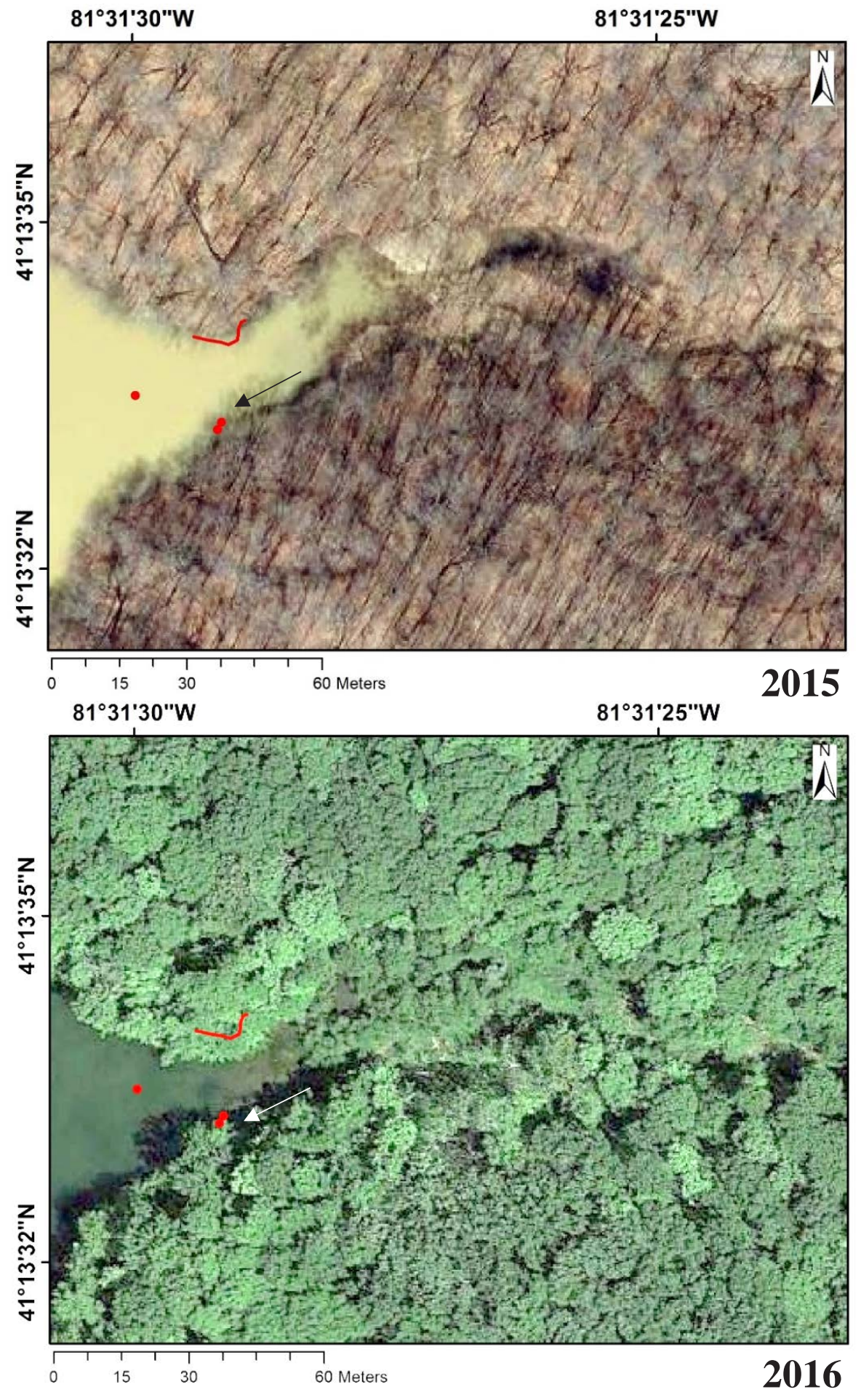

Figure 43. Lake Litchfield delta in 2015 and 2016. The leftmost dot is core LL-16-C1 and the rightmost dots are cores LL-16-C2 and C3 at the subaqueous delta. The red line is the year 2000 shoreline reference to determine relative water level change. Arrow shows delta progradation (Google, 2016; Summit County Parcel Viewer, 2016). 
Table 24. Lake Litchfield lake level relative to the year 2000 water level.

\begin{tabular}{cc}
\hline \hline Year & Water Level \\
\hline 1994 & Similar/deeper \\
2000 & Reference year \\
2003 & Unsure \\
2005 & Deeper \\
2006 & Shallower \\
2010 & Similar \\
2012 & Deeper \\
2014 & Similar \\
2015 & Deeper \\
2016 & Unsure \\
\hline
\end{tabular}


density decrease, whereas organic matter increases. At $90 \mathrm{~cm}$ core depth, the $\mathrm{D}_{50}$ was measured to be medium silt (Table 23). At the upper most $78 \mathrm{~cm}$, the lithologies present are clay, sand, and woody debris. Between 78-0 cm core depth, the organic matter and dry bulk density profiles display pronounced variation. An interval of alternating black and red clay, between $61-72 \mathrm{~cm}$, exhibits a large increase in organic matter content (13\%) and decrease in bulk density $\left(0.3 \mathrm{~g} / \mathrm{cm}^{3}\right)$. Grain size analysis of the samples from $45 \mathrm{~cm}$, $30 \mathrm{~cm}$, and $20 \mathrm{~cm}$ core depth had $\mathrm{D}_{50}$ values within the medium or fine silt range. Five downcore samples were tested for $\mathrm{Pb}, \mathrm{Zn}, \mathrm{Cu}$, and $\mathrm{Cr}$ heavy metal concentrations (Figure 34). $\mathrm{Zn}, \mathrm{Cu}$, and $\mathrm{Cr}$ concentrations remained low and uniform throughout the core. $\mathrm{Pb}$ concentrations increase up core and then decreased at the core top.

The $\chi$ ARM values for the five downcore samples are at or below $1.010^{-6} \mathrm{~m}^{3} \mathrm{~kg}^{-1}$ and SIRM values are less than 2,439 $10^{-6} \mathrm{~m}^{3} \mathrm{~kg}^{-1}$, indicating low concentrations of ferrimagnetic low coercivity minerals (Figure 35). Two of the five samples have greater than $2 \%$ frequency, indicating that the samples contain superparamagnetic grains. The remaining samples contain stable single domain grains (Figures 23 and 36). The S-ratio values are at or about 0.9 signifying a mixture of high and low coercively minerals.

A second core was obtained at the subaqueous levee, where Ritchie Run enters the impoundment. Core LL-16-C2 is $88.5 \mathrm{~cm}$ long and is comprised largely of sand (Figures 37 and 38). Organic matter content is consistently low ( 1\%) and the dry bulk density is high $\left(\sim 1.3 \mathrm{~g} / \mathrm{cm}^{3}\right)$. A layer of gravel is present between $56.5-54 \mathrm{~cm}$ core depth. Although the $\kappa$ increases in the gravel layer, the organic matter content and dry bulk density are similar to the sand lithology. There are woody debris layers at 30-25 cm and 74-70 cm core depth with corresponding decreases in bulk density and increases in organic content (Figure 38). The other two subaqueous levee cores, C3 and C4, recovered similar lithology to C2 (Appendix D). 


\subsubsection{Shoreline Change}

Aerial photographs of the delta at the upstream end of Lake Litchfield were analyzed to document sediment deposition changes and shoreline progradation from 1994 to 2016 (Figures 39-43). Lake level fluctuates in Lake Litchfield; therefore, each photograph year was compared to the year 2000 water level indicator. In 1994, the river mouth is set back into the stream valley. The water level is higher in 1994, 2005, 2012, and 2015 compared to the year 2000 waterline reference (Table 24). A reference point was marked on the map for 1994, 2000, 2003, 2005, 2010, and 2015 to track the growth rate of the river mouth (Table 25). From 1994-2000, the mouth of the river advanced approximately 33 meters. It was thought that with the evidence from Delaney (2016) and Liberator (2013) there would be a faster delta growth rate in Lake Litchfield after 2003 with increased regional flooding. After analysis, however, it was determined there was no significant increase after 2003 in the prograding delta. The total delta growth from 1994-2015 was approximately 74.5 meters. In August of 2016, Lake Litchfield was drained to repair a valve, which exposed the lakebed and shoreline features. During a data collection trip in September 2016, photos were captured of the exposed delta and sedimentary structures. This was the first time the lake was drained in its 40 -year history.

\subsubsection{Land cover}

Percent area of land cover and percent area land cover change were tabulated and analyzed for Lake Litchfield (Figure 44; Table 26; Appendix E). The total area of the Ritchie Run watershed is 1,665,000 $\mathrm{m}^{2}$. From 1985-2010, the Ritchie Run watershed had no change in developed, farmland, undeveloped, or open water land cover. As of 2010, $3.4 \%\left(55,800 \mathrm{~m}^{2}\right)$ of the watershed was developed, $3.5 \%\left(58,500 \mathrm{~m}^{2}\right)$ was farmland, and

$86 \%\left(1,437,300 \mathrm{~m}^{2}\right)$ was undeveloped land cover. Due to land cover classes not changing, there was no change in impervious surfaces from 1985-2010. Of the total watershed, 
Table 25. Delta growth from 1994 to 2015 at Lake Litchfield.

\begin{tabular}{cccc}
\hline \hline Year & Month & $\begin{array}{c}\text { Distance from } \\
\text { Reference Point } \\
\text { (m) }\end{array}$ & $\begin{array}{c}\text { Delta growth/month } \\
\text { (meters/month) }\end{array}$ \\
\hline 1994 & April & 40 & - \\
2000 & April & 72.5 & 0.45 \\
2003 & July & 72.5 & 0.00 \\
2005 & April & 76.5 & 0.17 \\
2010 & April & 99.2 & 0.38 \\
2015 & April & 114.5 & 0.26 \\
\hline
\end{tabular}



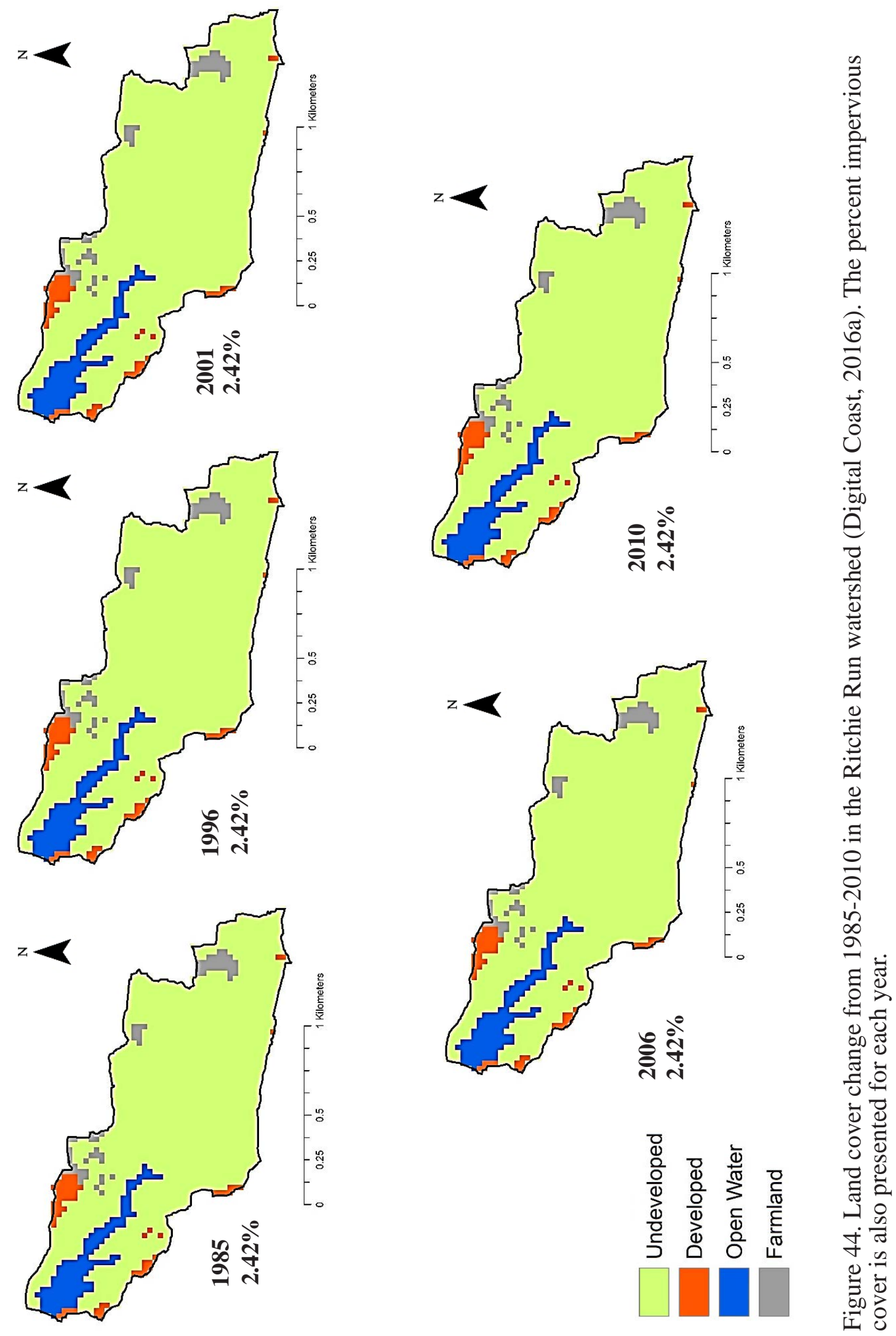


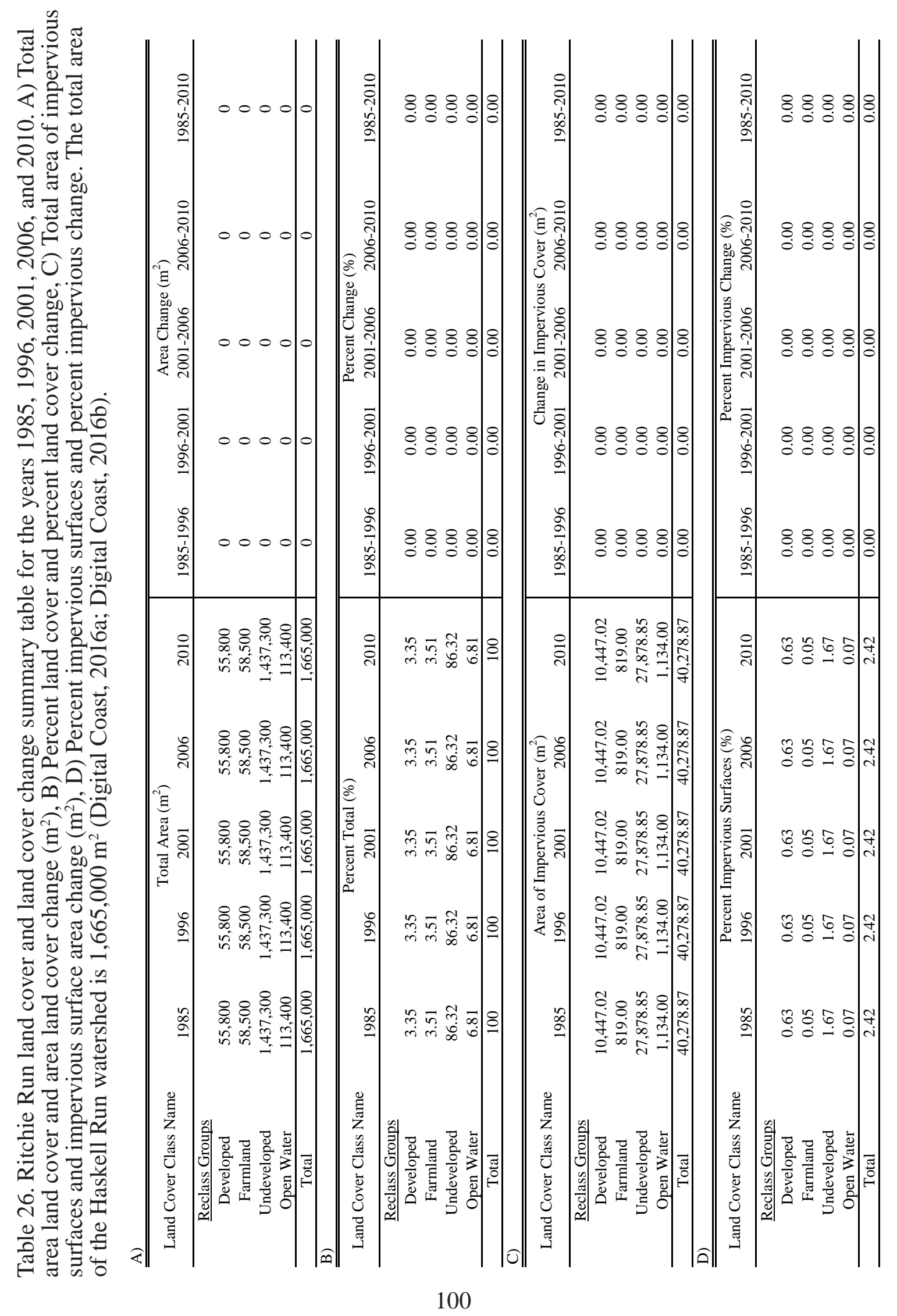


$2.42 \%$ is considered impervious cover, with $0.63 \%$ coming from developed land cover and $1.67 \%$ from undeveloped land cover. The main contribution for developed land cover in the Ritchie Run watershed is largely the Boy Scout camp and parts of Truxell Road.

\subsection{Old Mill Pond}

Surficial and core sediment properties were analyzed from the Old Mill Pond impoundment. Shorelines at the Old Mill Pond delta were assessed from 1994 to 2016. Land cover changes were determined for the Mud Brook watershed from 1985 to 2010.

\subsubsection{Surface Samples}

Thirteen surface samples were collected from the Old Mill Pond impoundment. Eleven samples were collected from the impoundment, and two were collected in the culvert closest to the dam (Figure 45). The impoundment surficial sediment is an organicrich clay that changes to sand and gravel closer to the dam and culvert. Porosity, organic matter content, dry bulk density, mass-corrected susceptibility, and visual grain size were measured on all surface samples (Table 27). Mud samples have porosities between 70-77\%, organic matter content between $10.3-11.3 \%$, bulk density of about $0.32 \mathrm{~g} / \mathrm{cm}^{3}$, and a susceptibility range of $41-10410^{-8} \mathrm{~m}^{3} \mathrm{~kg}^{-1}$. The mud sample G4, collected in the river channel heading toward the dam, had a notably higher susceptibility of $10410^{-8} \mathrm{~m}^{3}$ $\mathrm{kg}^{-1}$ when compared to the other mud samples. Sand and pebble-dominated samples had porosities between 23-32\%, organic matter content of 3.4-4.8\%, dry bulk density between $1.26-1.56 \mathrm{~g} / \mathrm{cm}^{3}$, and susceptibility that ranged from $73-13910^{-8} \mathrm{~m}^{3} \mathrm{~kg}^{-1}$. Grain size was determined for samples G3,7,8,9, and 12 (Table 28; Appendix F). The culvert samples G7 and G8 were very poorly sorted, very coarse sand to coarse sand. The $D_{50}$ for G3, 9 and 12 were determined to be fine silt to very fine silt. 


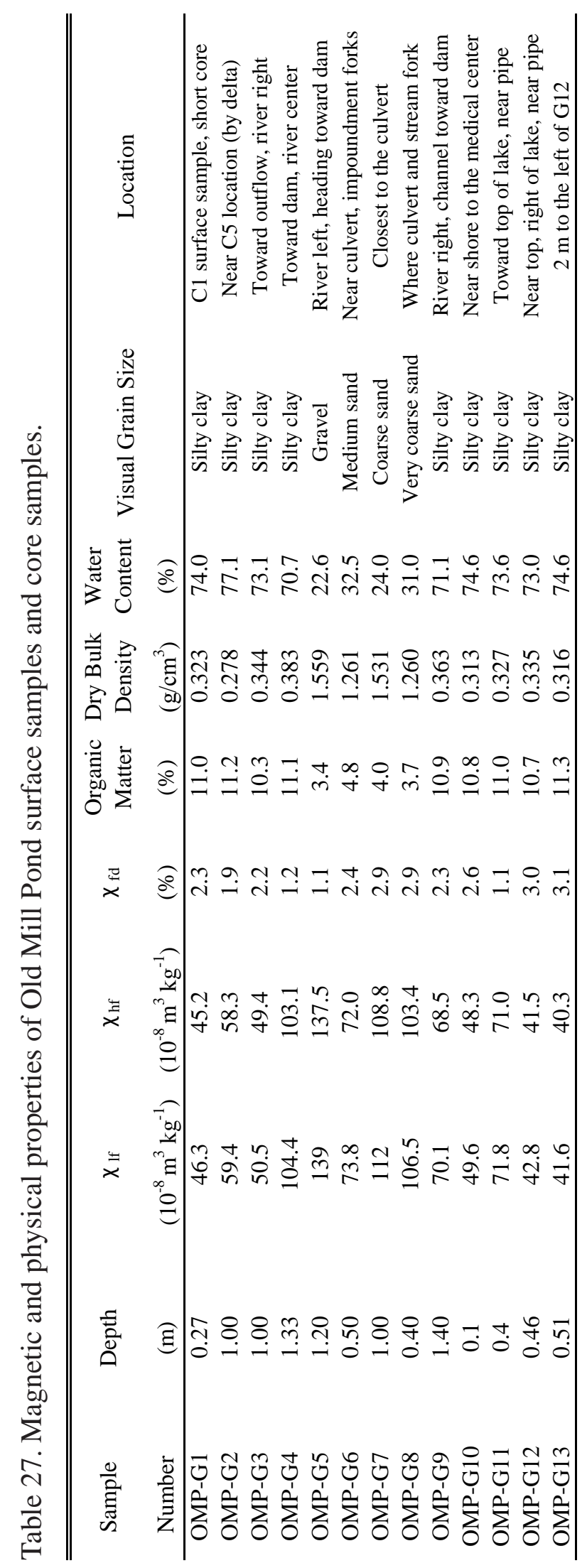




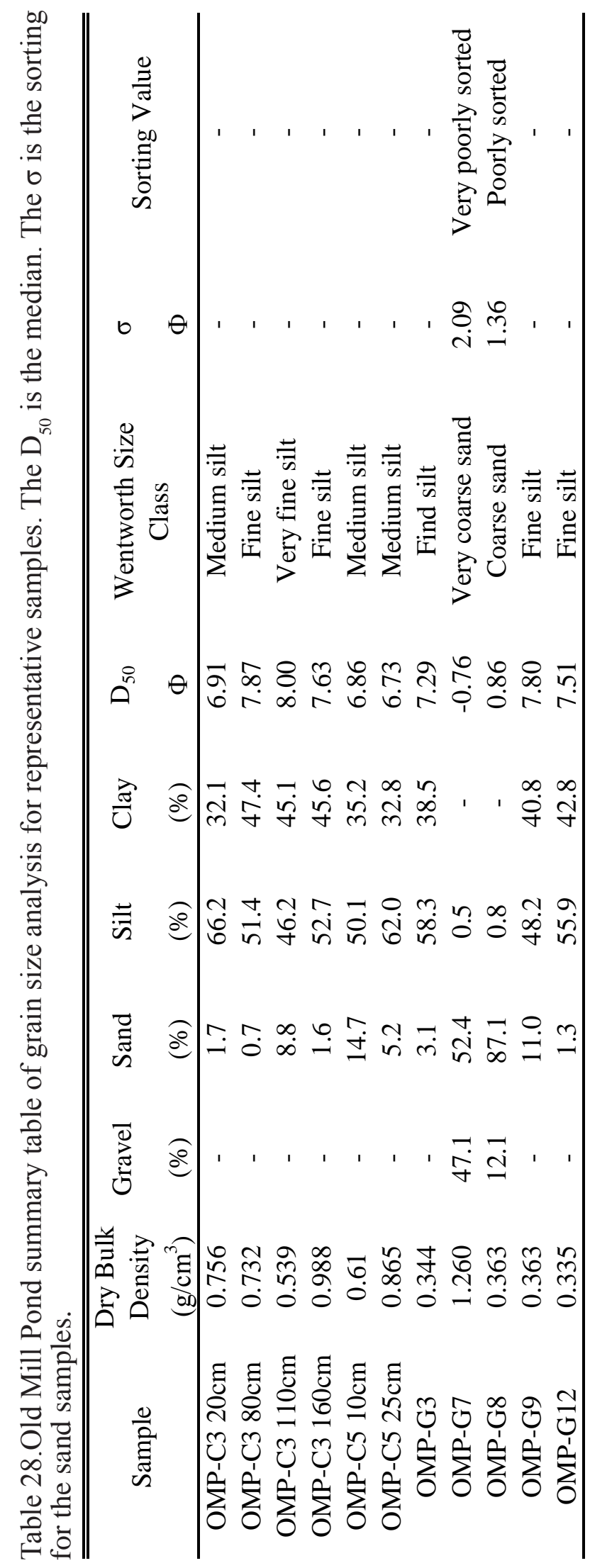


Table 29. Heavy metal concentrations for selected Old Mill Pond sediment samples.

\begin{tabular}{ccccc}
\hline \hline Sample & $\begin{array}{c}\text { Pb } \\
\text { Concentration } \\
(\mu \mathrm{g} / \mathrm{g})\end{array}$ & $\begin{array}{c}\mathrm{Zn} \\
\text { Concentration } \\
(\mu \mathrm{g} / \mathrm{g})\end{array}$ & $\begin{array}{c}\mathrm{Cu} \\
\text { Concentration } \\
(\mu \mathrm{g} / \mathrm{g})\end{array}$ & $\begin{array}{c}\text { Cr } \\
\text { Concentration } \\
(\mu \mathrm{g} / \mathrm{g})\end{array}$ \\
\hline Surface & & & & \\
OMP-G1 & 48.8 & 213.6 & 40.6 & 68.1 \\
OMP-G3 & 31.2 & 232.9 & 61.9 & 65.8 \\
OMP-G4 & 4.6 & 217.7 & 51.8 & 58.2 \\
OMP-G7 & 56.3 & 93.4 & 14.1 & 24.1 \\
OMP-G8 & 28.4 & 92.7 & 10.6 & 18.6 \\
OMP-G9 & 48.5 & 257.8 & 61.1 & 67.4 \\
OMP-G11 & 21.1 & 168.2 & 32.3 & 45.8 \\
OMP-G12 & 42.9 & 222.8 & 54.6 & 69.8 \\
Cores & & & & \\
OMP-C3 1cm & 42.1 & 213.1 & 53.9 & 58.9 \\
OMP-C3 20cm & 29.7 & 213.7 & 47.8 & 58.6 \\
OMP-C3 40cm & 55.8 & 187.6 & 46.0 & 57.8 \\
OMP-C3 60cm & 74.5 & 199.8 & 44.0 & 61.3 \\
OMP-C3 80cm & 113.0 & 263.0 & 51.5 & 136.0 \\
OMP-C3 80cm R & 121.8 & 261.4 & 48.3 & 133.2 \\
OMP-C3 100cm & 93.8 & 223.6 & 51.5 & 75.4 \\
OMP-C3 110cm & 93.6 & 238.4 & 47.3 & 97.3 \\
OMP-C3 120cm & 41.3 & 183.3 & 40.5 & 74.8 \\
OMP-C3 120cm R & 38.1 & 188.4 & 39.1 & 72.0 \\
OMP-C3 140cm & 32.1 & 200.3 & 28.5 & 54.0 \\
OMP-C3 160cm & 23.5 & 113.7 & 22.1 & 50.7 \\
\hline
\end{tabular}



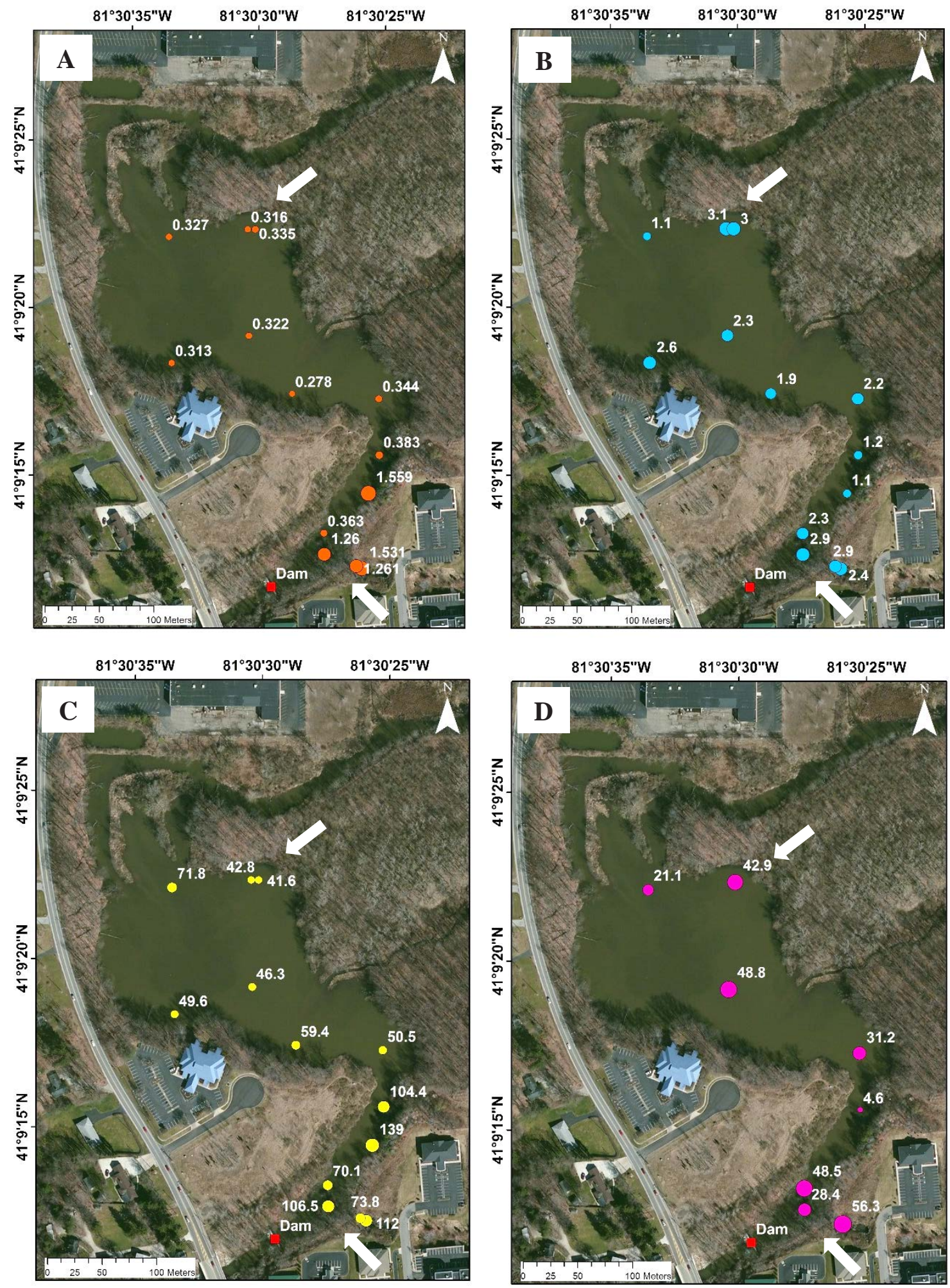

Figure 45. Old Mill Pond surface sediment values for A) dry bulk density $\left.\left(\mathrm{g} / \mathrm{cm}^{3}\right), \mathrm{B}\right)$ susceptibility frequency dependance $(\%), C)$ magnetic susceptibility $\left(10^{-8} \mathrm{~m}^{3} \mathrm{~kg}^{-1}\right)$, and D) $\mathrm{Pb}$ content $(\mu \mathrm{g} / \mathrm{g})$. Arrows indicate location of drainage pipe and culvert (ESRI, 2016a). 
Eight grab samples $(\mathrm{G} 1,3,4,7,8,9,11,12)$ were analyzed for $\mathrm{Pb}, \mathrm{Zn}, \mathrm{Cu}$, and $\mathrm{Cr}$ heavy metal concentrations (Table 29). Pb concentrations ranged between 21-56 $\mu \mathrm{g} / \mathrm{g}$, with one sample (G4) having a low concentration of $4.6 \mu \mathrm{g} / \mathrm{g}$. Zn concentrations were between 192-257 $\mu \mathrm{g} / \mathrm{g}$. Cu concentrations were between 10-62 $\mu \mathrm{g} / \mathrm{g}$, and $\mathrm{Cr}$ concentrations ranged from $18-70 \mu \mathrm{g} / \mathrm{g}$. Except for Pb concentration, the sandy culvert samples (G7 and G8) had noticeably lower $\mathrm{Zn}$, $\mathrm{Cu}$, and $\mathrm{Cr}$ concentrations compared to all the other samples.

The surficial sediment samples measured for heavy metals were also analyzed for magnetic properties (Appendix C). The magnetic concentration of the had an average SIRM of $5,85210^{-6} \mathrm{Am}^{2} \mathrm{~kg}^{-1}$, an average $\chi_{\mathrm{If}}$ of $7610^{-8} \mathrm{~m}^{3} \mathrm{~kg}^{-1}$, and the $\chi \mathrm{ARM}$ average was $2.310^{-6} \mathrm{~m}^{3} \mathrm{~kg}^{-1}$. These values are indicative of high ferrimagnetic concentration in the mud samples. The sand samples from the culvert (G7 and 8) exhibited significantly higher ferrimagnetic concentrations than the mud samples. The SIRM for G7 and G8 was 12,782 $10^{-6} \mathrm{Am}^{2} \mathrm{~kg}^{-1}$ and $10,04510^{-6} \mathrm{Am}^{2} \mathrm{~kg}^{-1}$, respectively. The S-ratio for all samples was above 0.92, indicating ferrimagnetic, low coercively minerals. The concentration of ferrimagnetic minerals was highest where the Mud Brook channel narrows approaching the dam at the culvert.

\subsubsection{Sediment Cores}

Sediment cores were collected from Old Mill Pond in May 2016. Cores were taken from the middle of the impoundment (OMP-16-C1-C2) and near the subaqueous levee of a small stream entering the eastern side of the impoundment (Figure 16). Cores were analyzed for visual lithology, whole-core susceptibility, organic matter content, bulk density, grain size, heavy metal concentration, and magnetic properties.

The longest core from the middle of the impoundment, OMP-16-C3, is $165.5 \mathrm{~cm}$ long and can be divided into three sections: $165.5-150 \mathrm{~cm}, 150-70 \mathrm{~cm}$, and 70-0 cm (Figure 46 and 47). Overall, in the whole core, the susceptibility ranges from $12-2110^{-5}$ Relative 


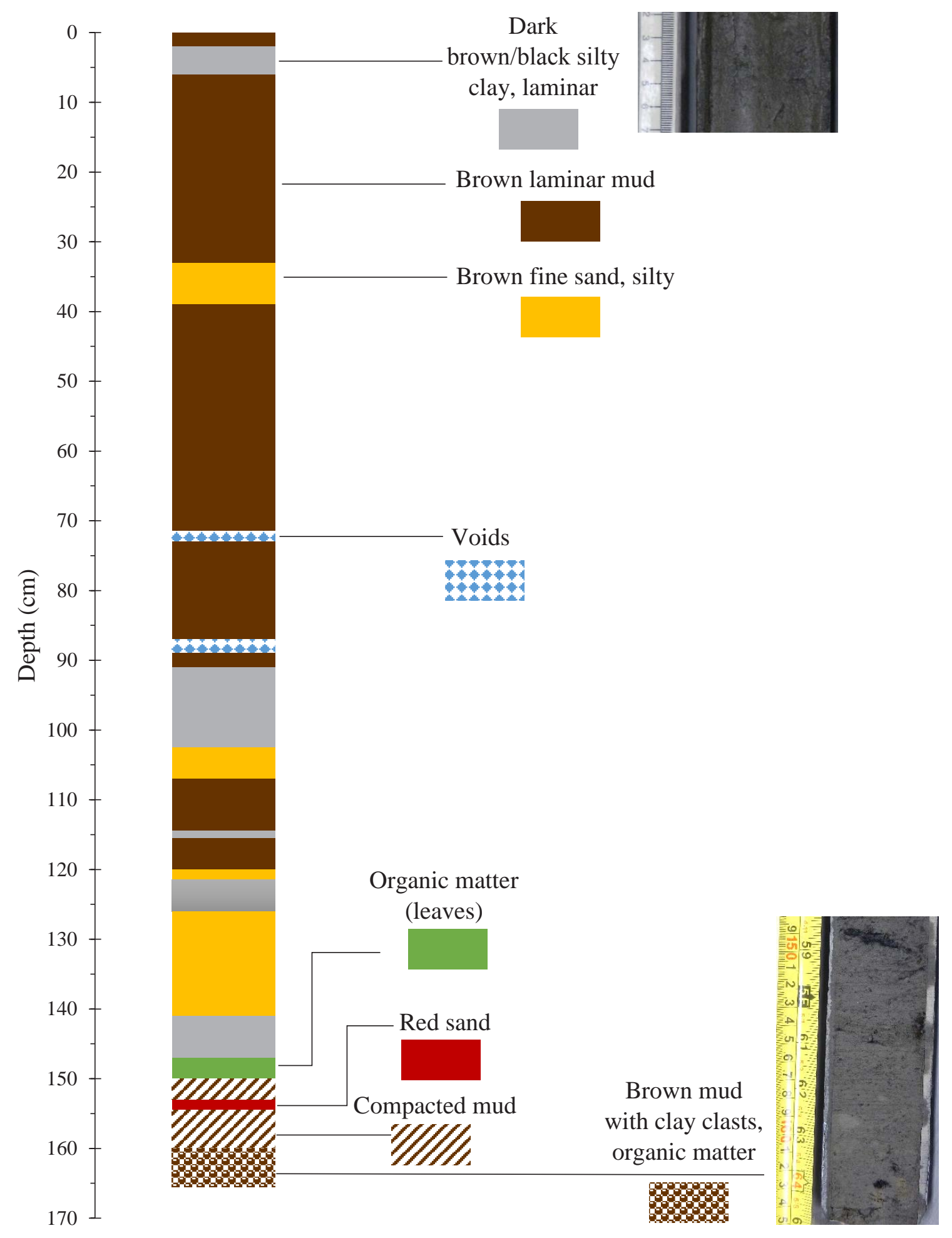

Figure 46. Detailed lithology description for core Old Mill Pond sediment core OMP16-C3. 


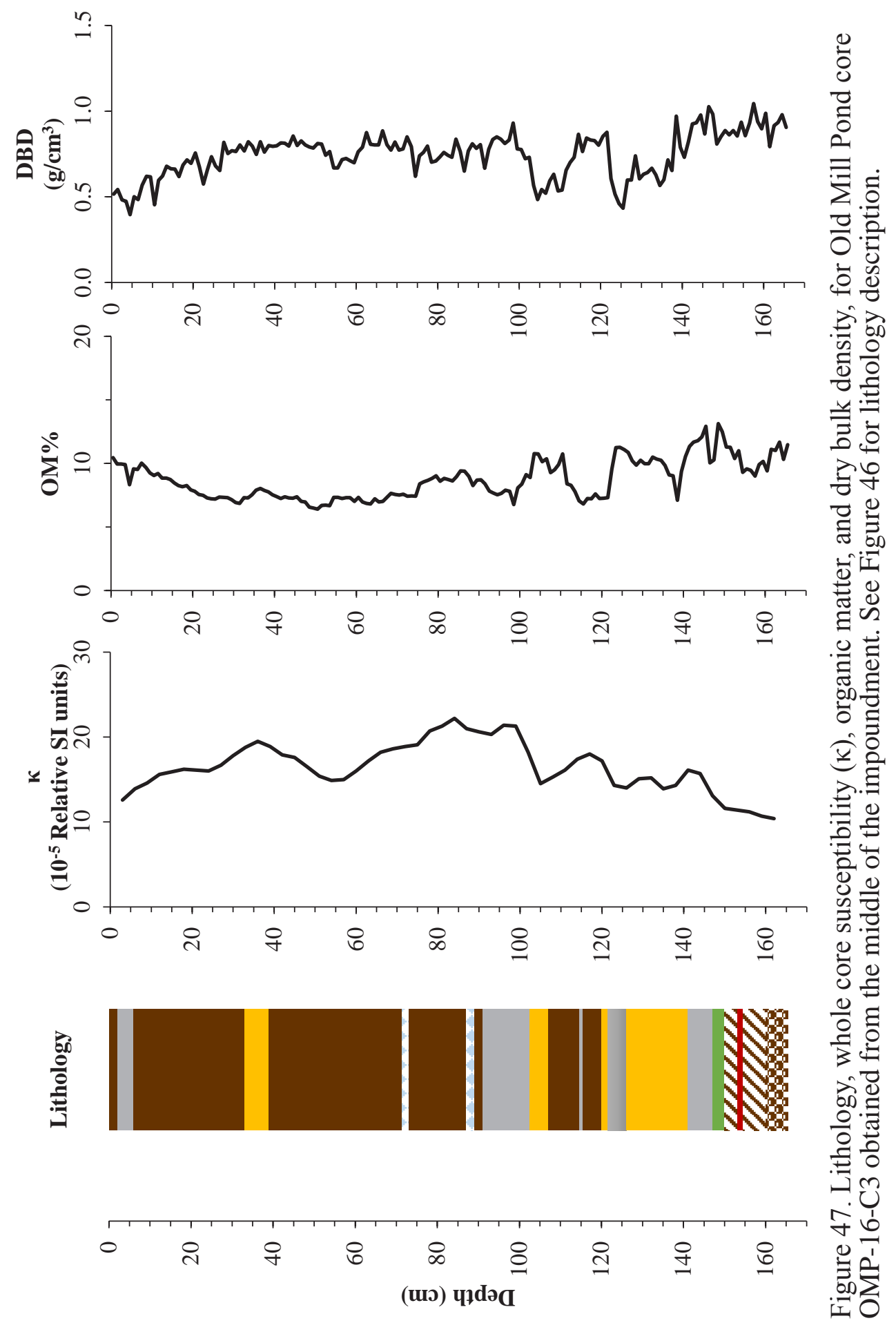


SI Units, organic matter ranges from $8-12 \%$, and bulk density ranges from $0.4-1.0 \mathrm{~g} / \mathrm{cm}^{3}$. In the first interval, between $165.5-150 \mathrm{~cm}$ core depth, susceptibility increases up core, whereas, organic matter content and dry bulk density are uniform. Within this section, compacted mud containing roots is present in addition to a red sandy layer between 154.5-153 cm core depth (Figure 46). Within the lower section, from 165.5 to $160 \mathrm{~cm}$, rounded grey clay clasts are present in a brown, compacted mud. Grain size analyzed at $160 \mathrm{~cm}$ indicates the $\mathrm{D}_{50}$ is fine silt (Table 28). Between $150-70 \mathrm{~cm}$, the lithologies present are clay, iron-stained sand, silt, and woody debris. The $\mathrm{D}_{50}$ at $110 \mathrm{~cm}$ and $80 \mathrm{~cm}$ core depth was measured to be very fine silt and fine silt, respectively (Table 28). Ironstained sand layers, that also contain organic matter, have lower dry bulk density and increased organic matter and susceptibility. The clay units within this section have an increase in susceptibility dry bulk density, and a decrease in organic matter. Between 70-0 $\mathrm{cm}$, the predominant lithology is mud with variable susceptibility and a uniform organic matter and bulk density. A sand and woody debris layer, between 39-33 cm core depth, has high susceptibility and organic matter. In the uppermost $13 \mathrm{~cm}$, the susceptibility and dry bulk density decrease, whereas organic matter increases.

Heavy metal concentrations for $\mathrm{Pb}, \mathrm{Zn}, \mathrm{Cu}$, and $\mathrm{Cr}$ were measured on 10 core $\mathrm{C} 3$ subsamples (Figure 48; Table 29). Between 160-120 cm, all heavy metal concentrations are low. In the entire core, the lowest heavy metal concentration for all metals occurred at $160 \mathrm{~cm}$ core depth. From 120 to $80 \mathrm{~cm}$ core depth, there is a gradual increase in all metal concentrations, with peak concentrations occurring at $80 \mathrm{~cm}$ for all metals. From 70 to 0 $\mathrm{cm}$, there is an overall decline in metal concentrations. Copper concentration is steadily increasing up core and at the surface, and has similar concentration to that of the $80 \mathrm{~cm}$ core depth. Zinc concentration remain uniform in the upper $60 \mathrm{~cm}$.

Magnetic properties of concentration, grain size, and minerology were determined for the ten core subsamples (Figures 49 and 50; Appendix C). The average $\chi \mathrm{ARM}$ was 

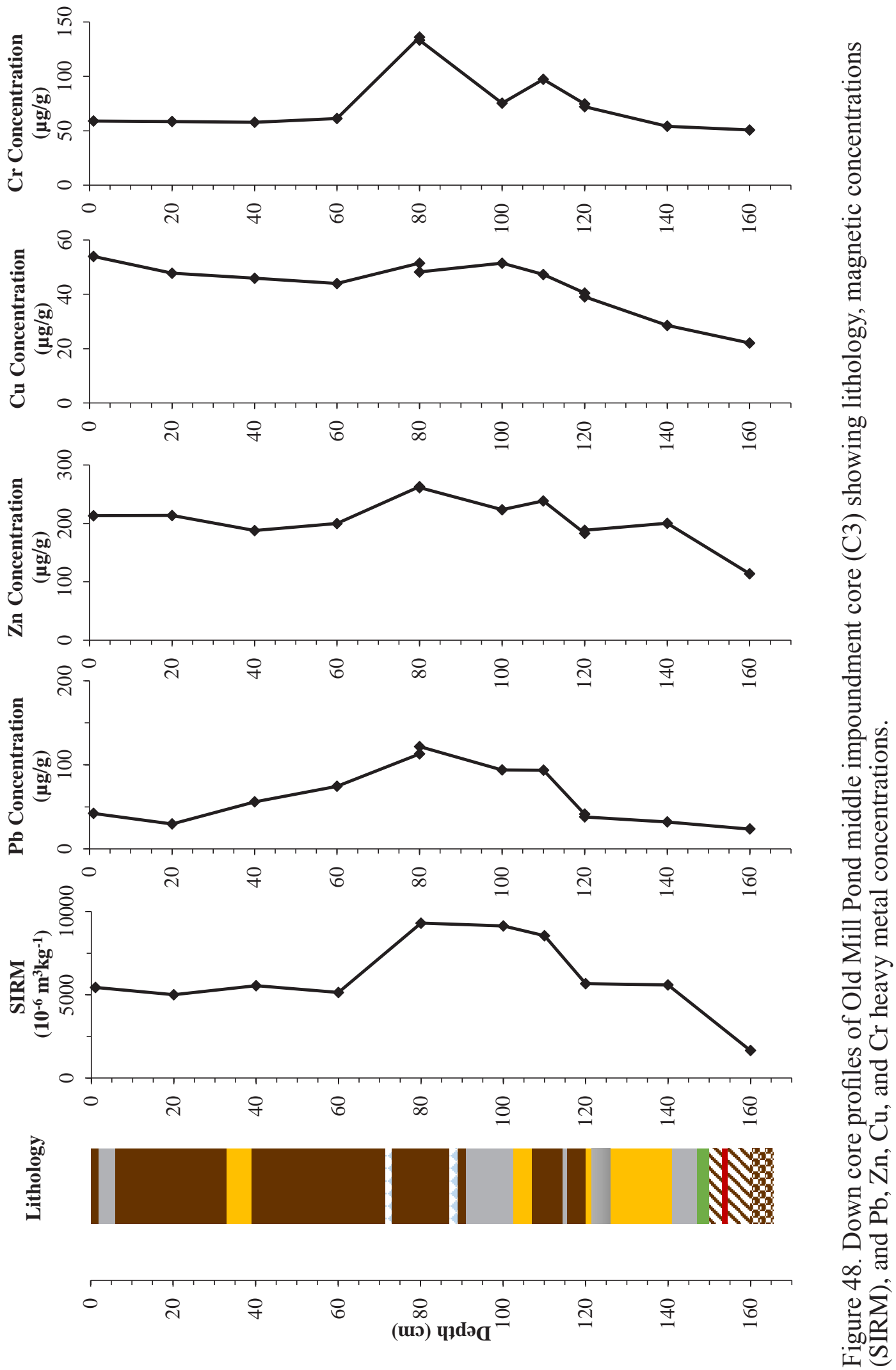


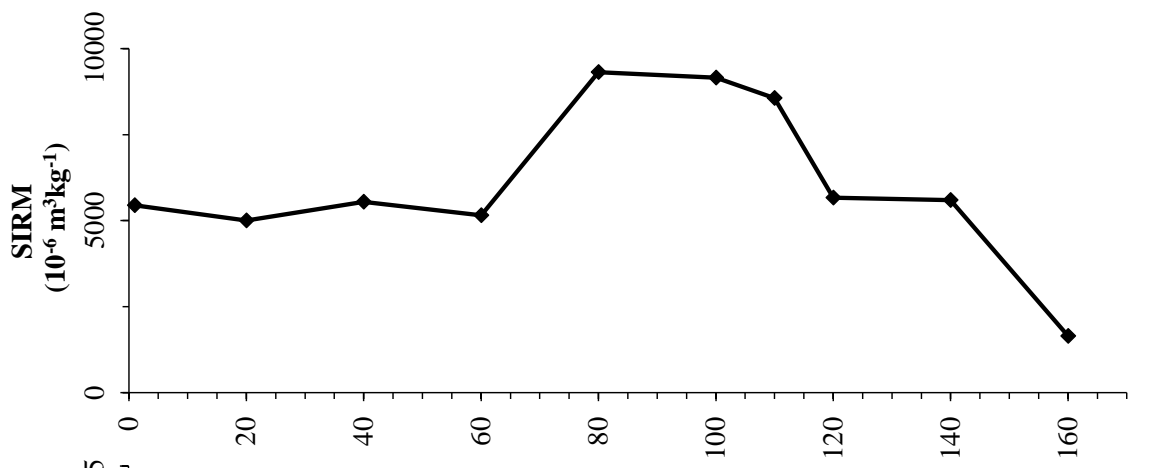

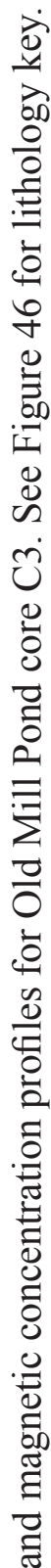
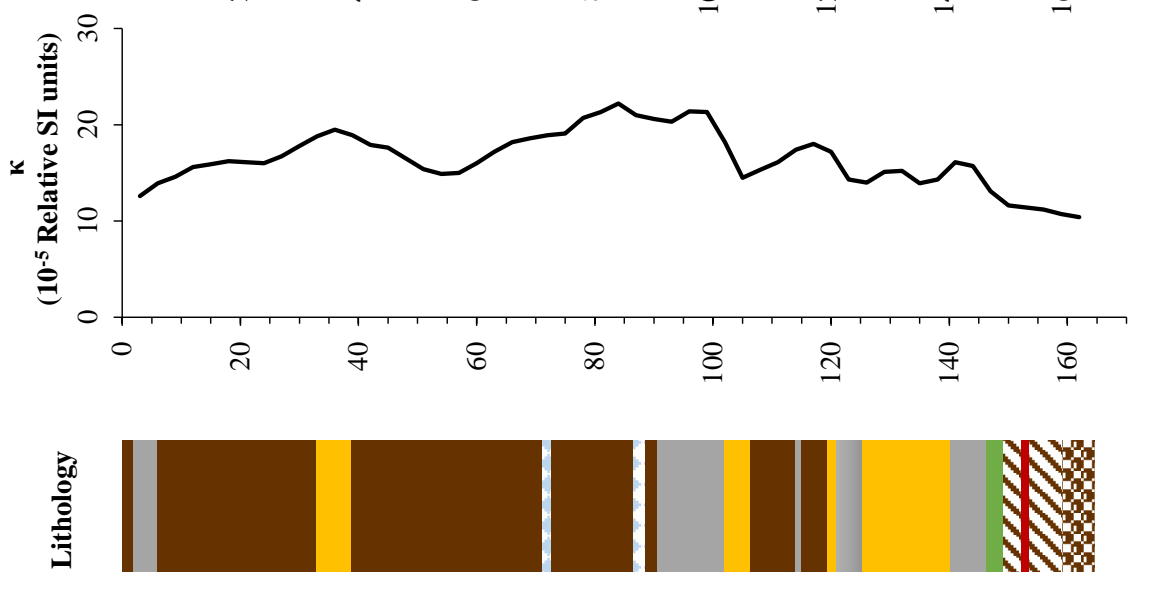

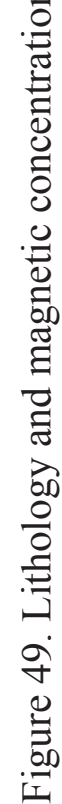

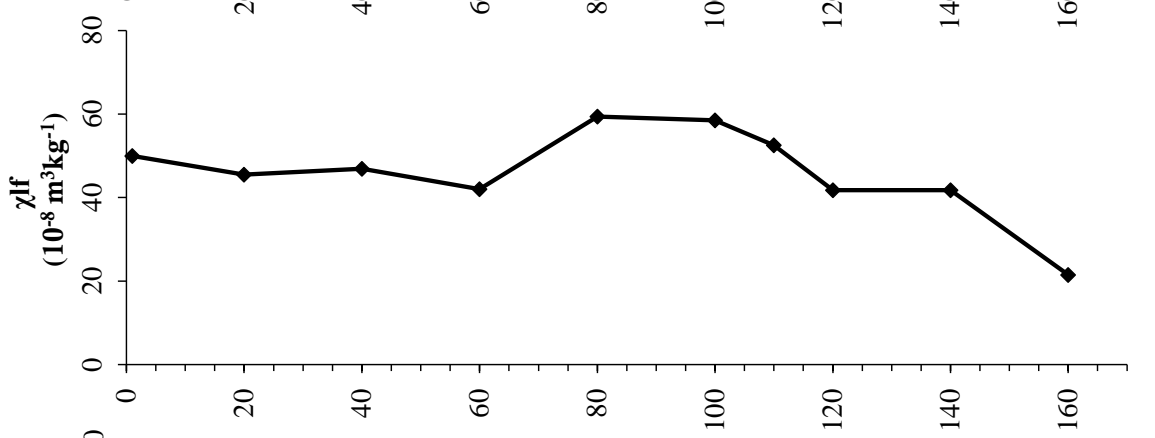




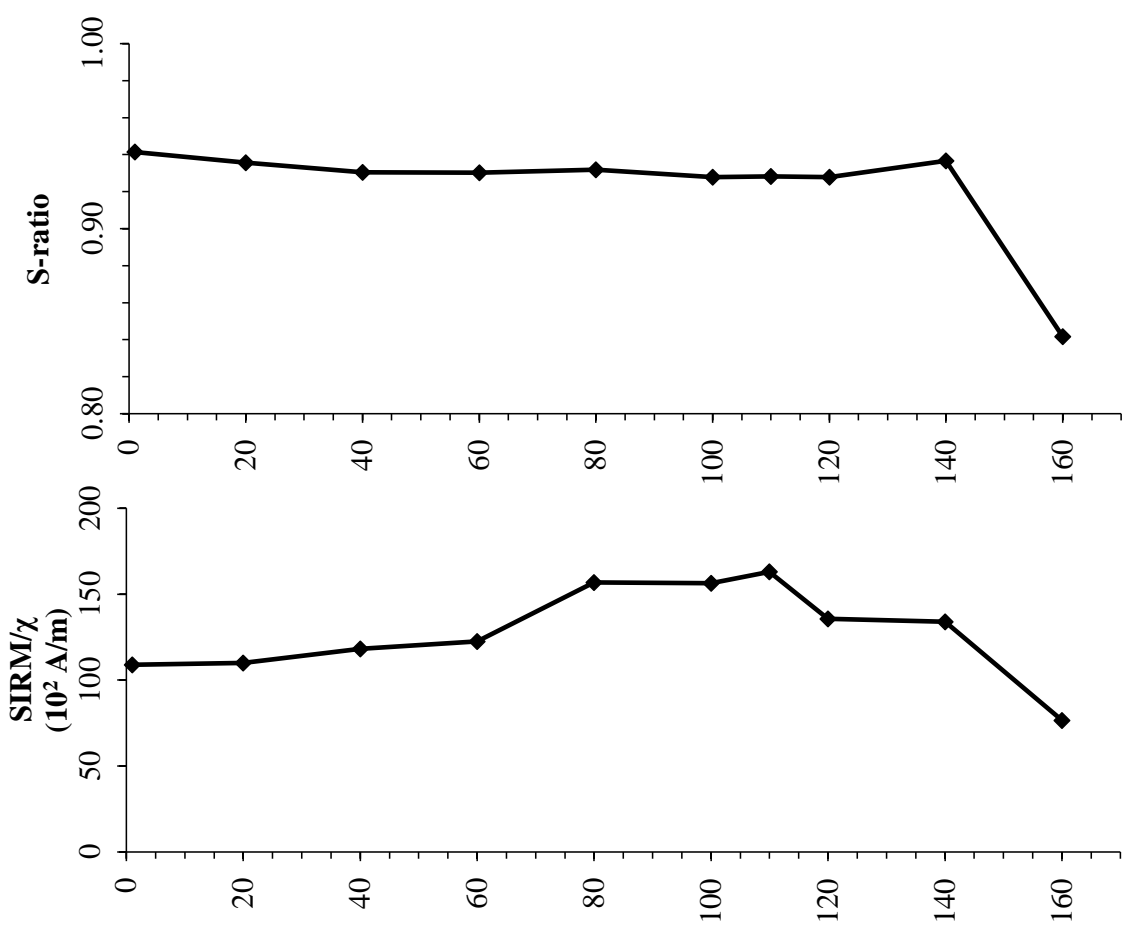

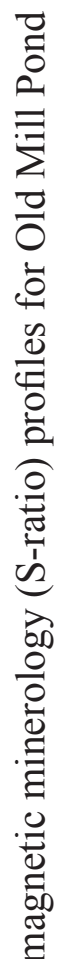
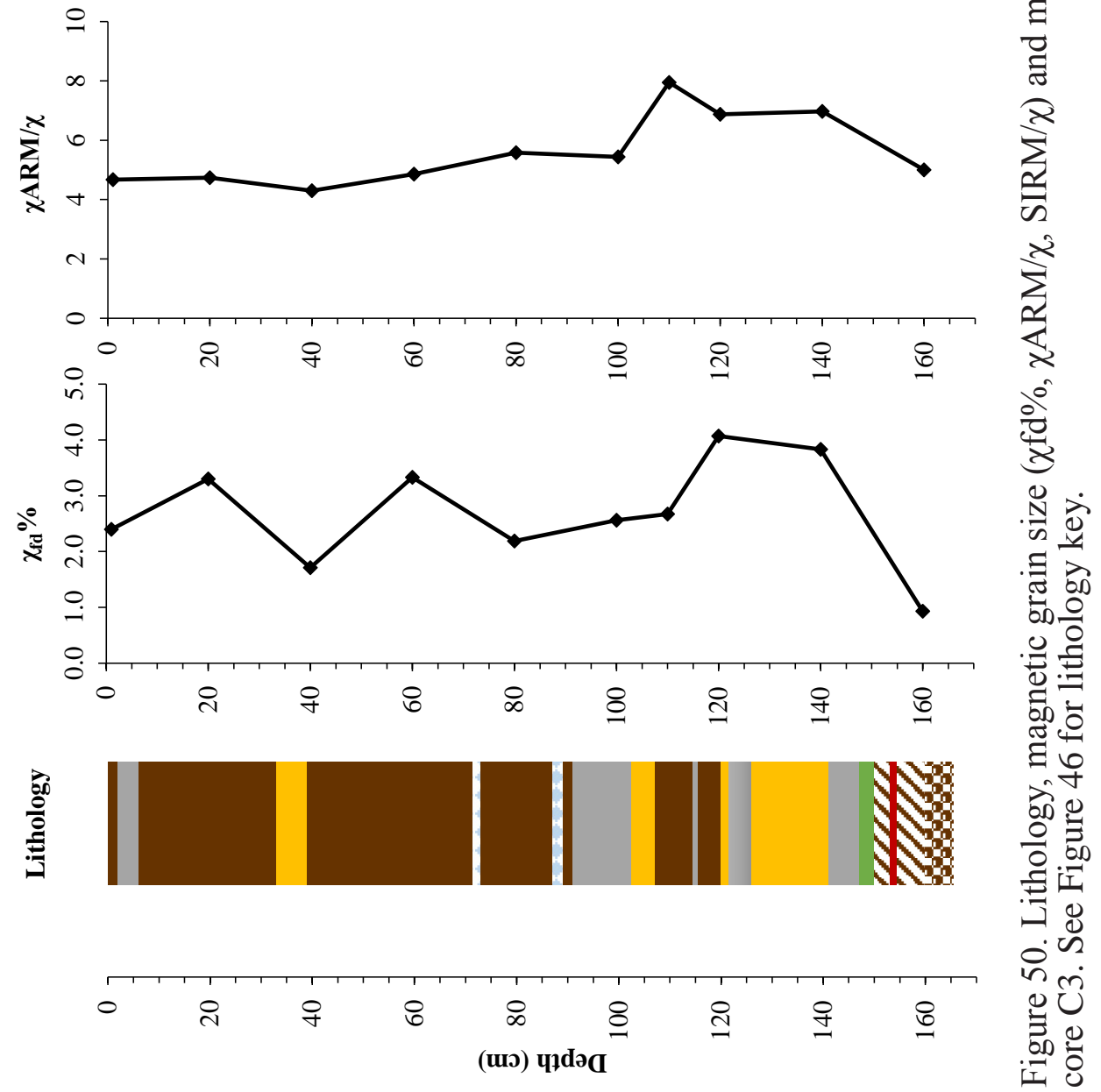
2.6 $10-6 \mathrm{~m}^{3} \mathrm{~kg}^{-1}$, the average $\chi_{\mathrm{If}}$ was $4610^{-8} \mathrm{~m}^{3} \mathrm{~kg}^{-1}$, and the average SIRM was $6,10010^{-6}$ $\mathrm{Am}^{2} \mathrm{~kg}^{-1}$ for the core samples. These ferrimagnetic concentration values indicate that the core contains high concentrations of ferrimagnetic particles. Between 120-80 cm core depth, where the heavy metals concentration was high, there is also a high concentration of ferrimagnetic particles (Figure 48). Throughout the core the magnetic grain size is uniform except the coarse magnetic grain sizes found at the bottom of the core at 160 cm core depth (Figure 49). The S-ratio for this deep sample at $160 \mathrm{~cm}$ is 0.84 , indicating a high proportion of high coercivity minerals (Figure 50). The remaining core samples have an S-ratio of about 0.93, which indicates the mineralogy is dominated by low coercivity, ferrimagnetic minerals.

A second core (OMP-16-C2), was obtained from the middle of the impoundment at the same location as C3. Core C2 has similar down-core trends in susceptibly, organic matter, and bulk density as C3 (Appendix D). Core C2, however, does not extend as deep as C3 and therefore was studied for heavy metal content.

A core was obtained from the subaqueous levee of a small stream entering the eastern side of the impoundment (OMP-16-C5). This core is $94.5 \mathrm{~cm}$ long and can be divided into three main sections: $94.5-50 \mathrm{~cm}, 50-30 \mathrm{~cm}$, and 30-0cm (Figures 51 and 52). Between $94.5-50 \mathrm{~cm}$, main lithology is a brown silty/clay with a layer of yellow clay 61$60 \mathrm{~cm}$ core depth. Susceptibility, organic matter content, and dry bulk density are largely uniform throughout this section (Figures 51 and 52). Between 50-30 cm core depth, brown silty/clay with organic matter is present. In this section, the susceptibility, dry bulk density, and organic content remains uniform. In the uppermost $30 \mathrm{~cm}$, there is a decrease in susceptibility and bulk density. It was observed that fine sand is present between 30$12 \mathrm{~cm}$, accompanied by an increase in bulk density; however, the $\mathrm{D}_{50}$ at $10 \mathrm{~cm}$ and 25 $\mathrm{cm}$ core depths was determined to be a medium silt (Table 28). Organic mud is present from 12-0 $\mathrm{cm}$ accompanied by an increase in organic matter. Five down core samples 


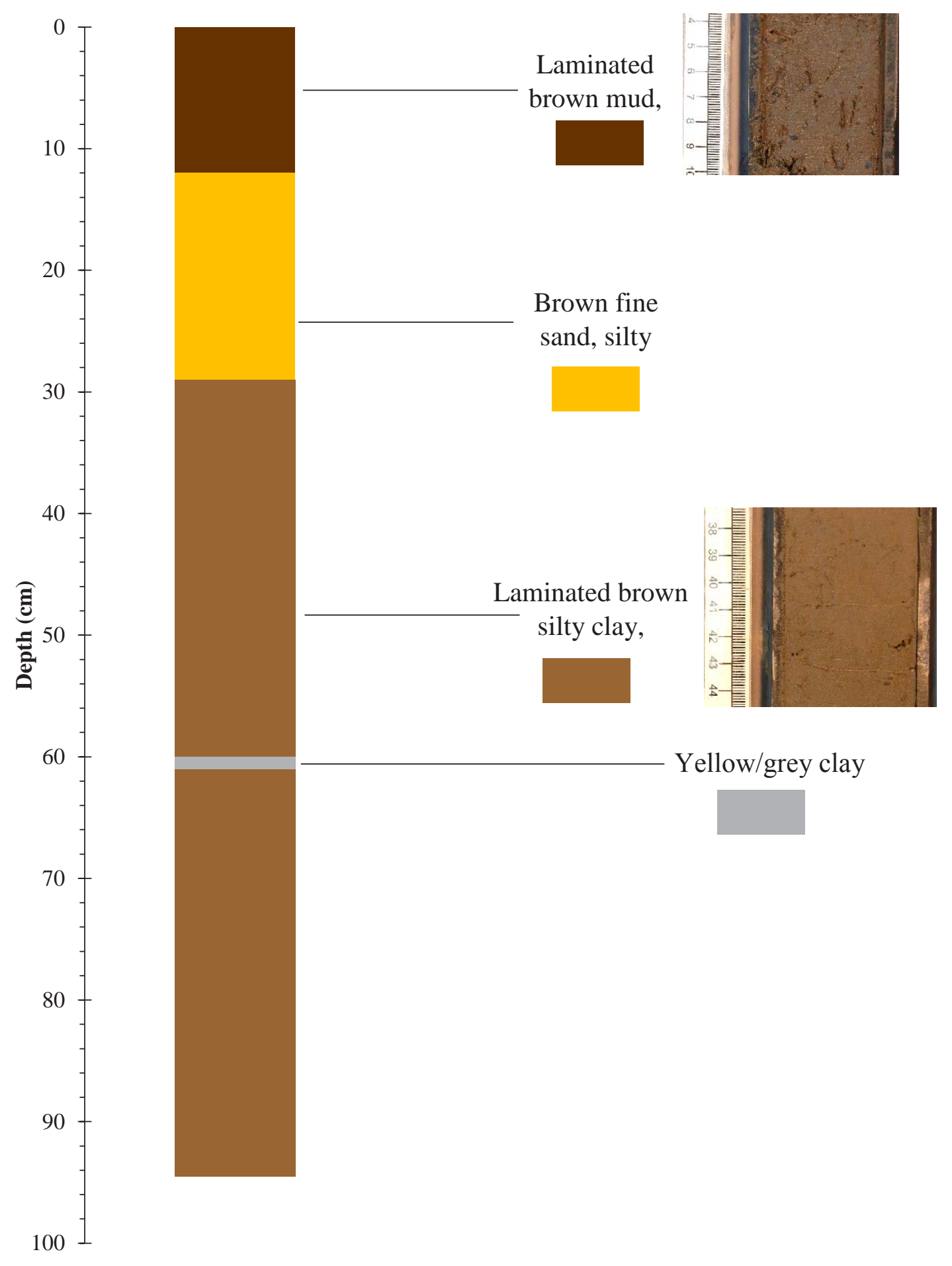

Figure 51. Detailed lithology description for Old Mill Pond sediment core OMP-16-C5. 

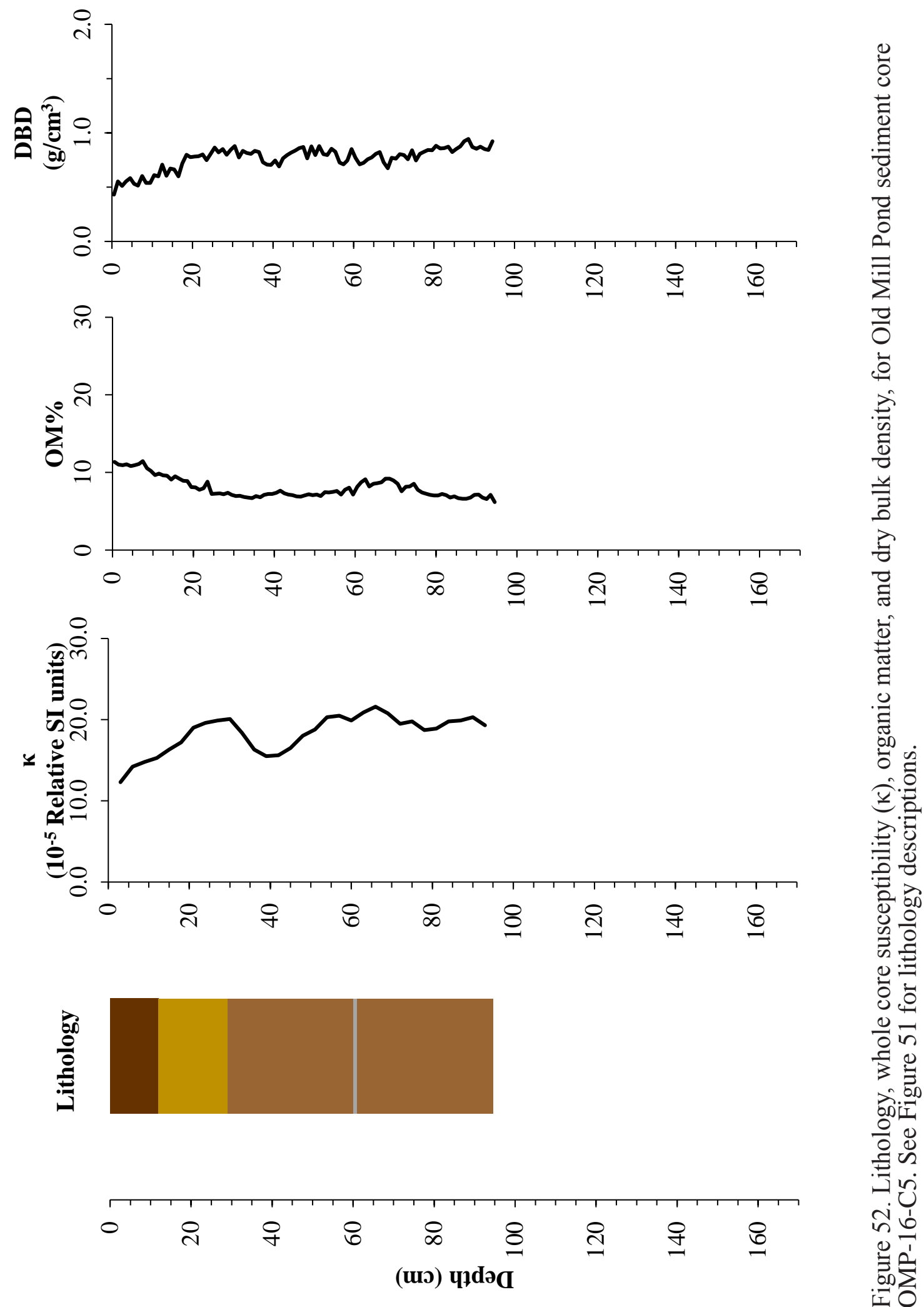

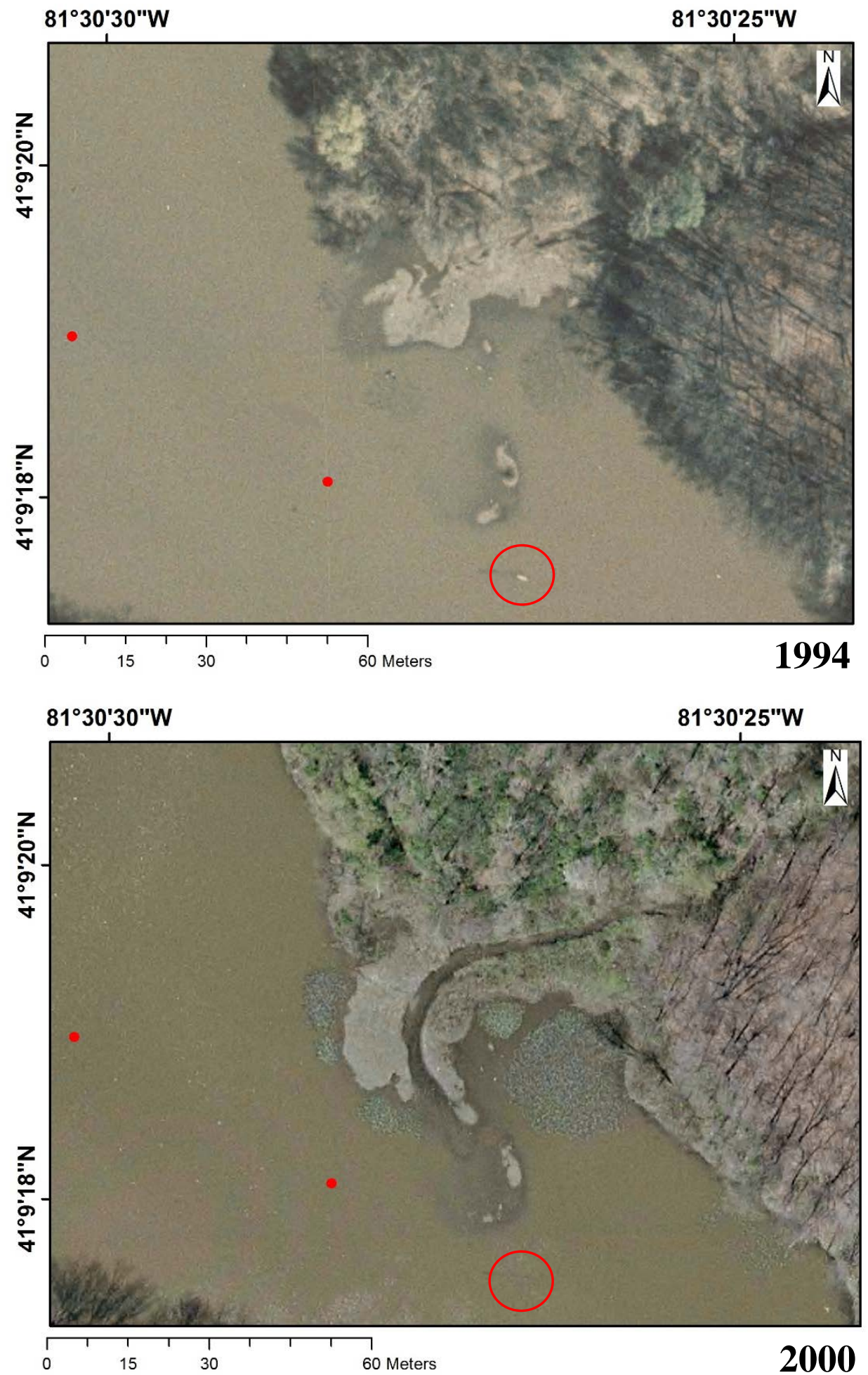

Figure 53. Old Mill Pond delta in 1994 and 2000. The leftmost red dot is the OMP-16-C3 core location and the rightmost dot is the OMP-16-C5 core location. The feature within the red circle is a stationary object used determine relative water level change (Summit County Fiscal Office, 2016). 

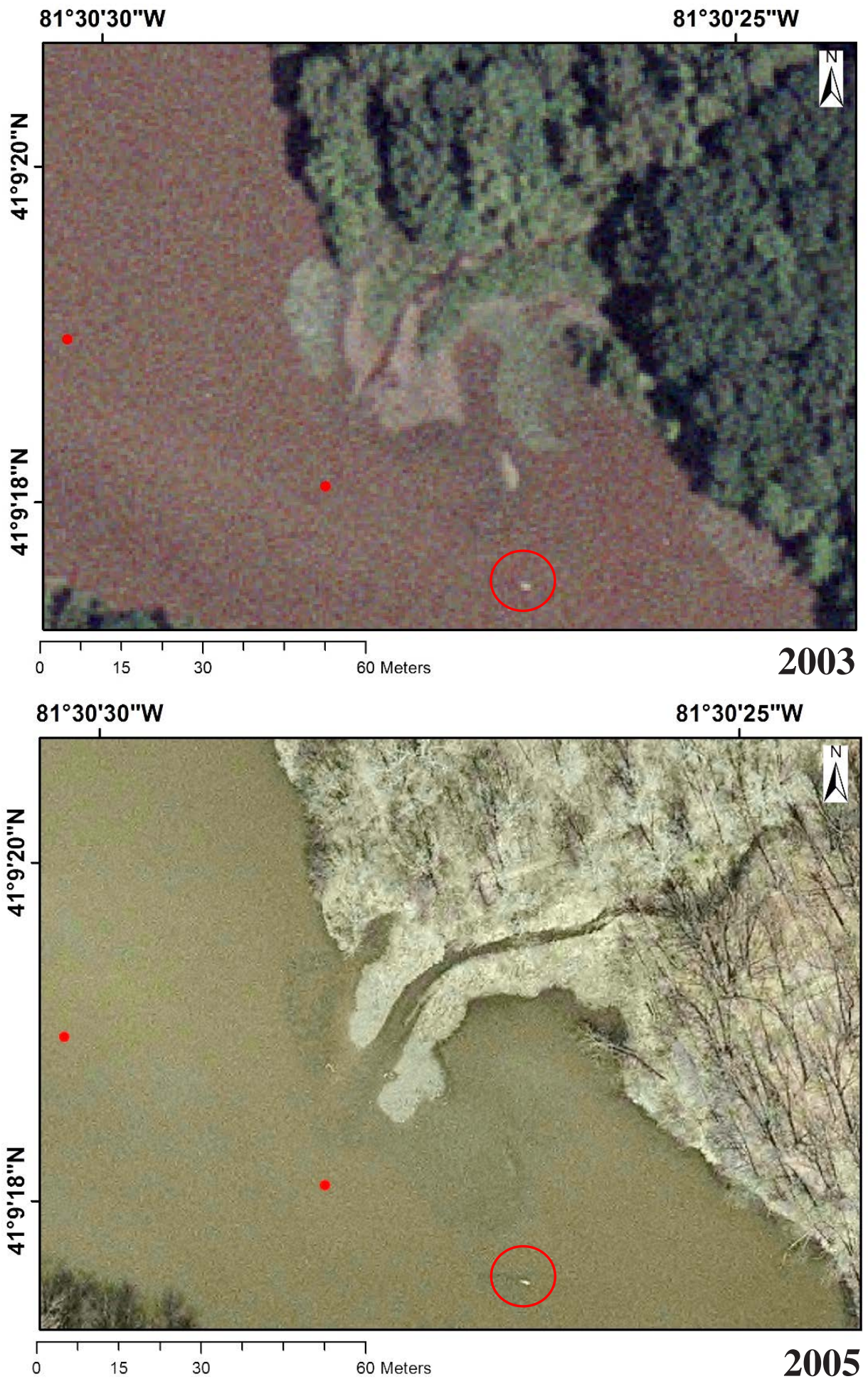

Figure 54. Old Mill Pond delta in 2003 and 2005. The leftmost red dot is the OMP-16-C3 core location and the rightmost dot is the OMP-16-C5 core location. The feature within the red circle is a stationary object used determine relative water level change (Summit County Fiscal Office, 2016; USGS, 2016b). 

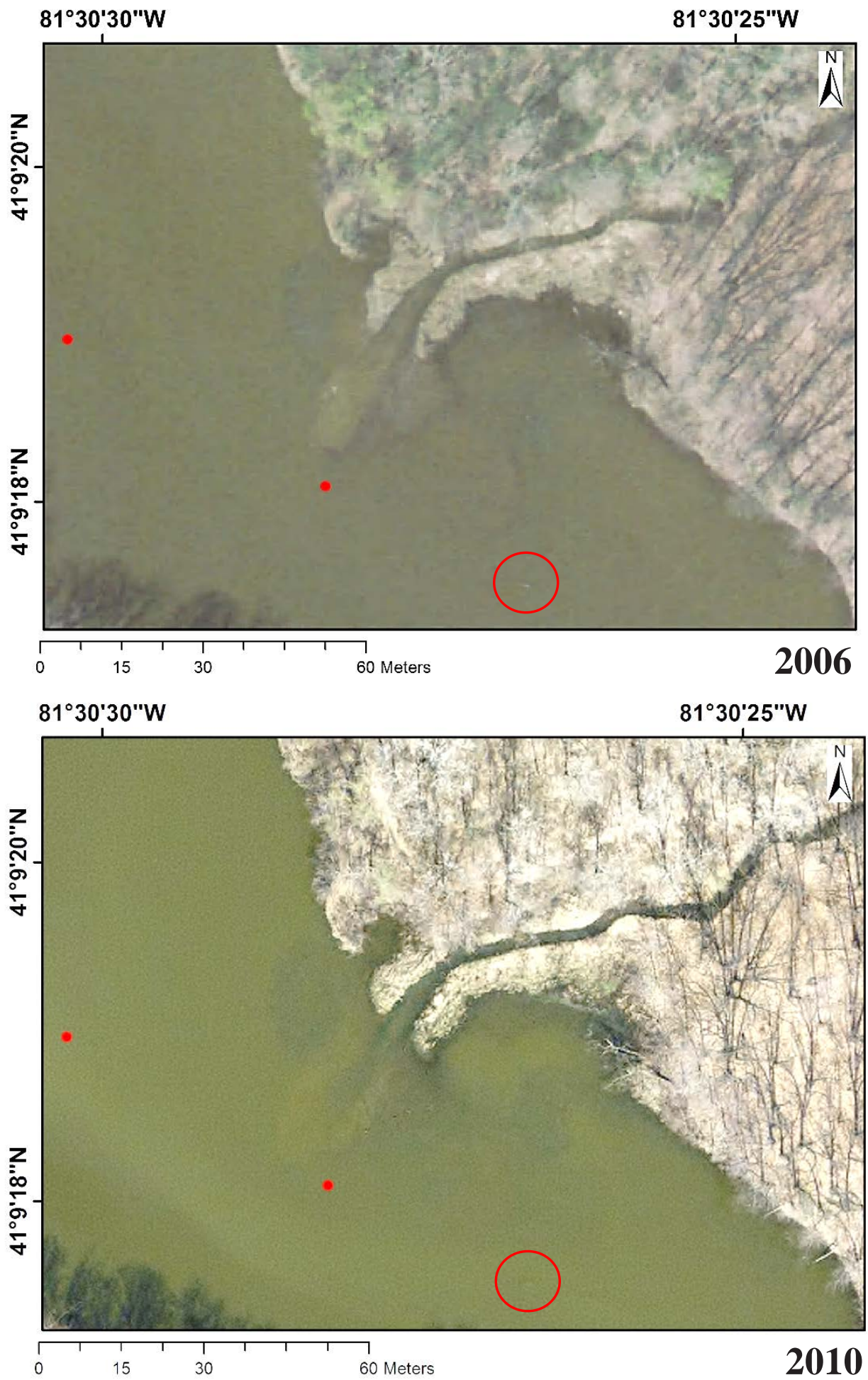

Figure 55. Old Mill Pond delta in 2006 and 2010. The leftmost red dot is the OMP-16-C3 core location and the rightmost dot is the OMP-16-C5 core location. The feature within the red circle is a stationary object used determine relative water level change (Summit County Fiscal Office, 2016). 

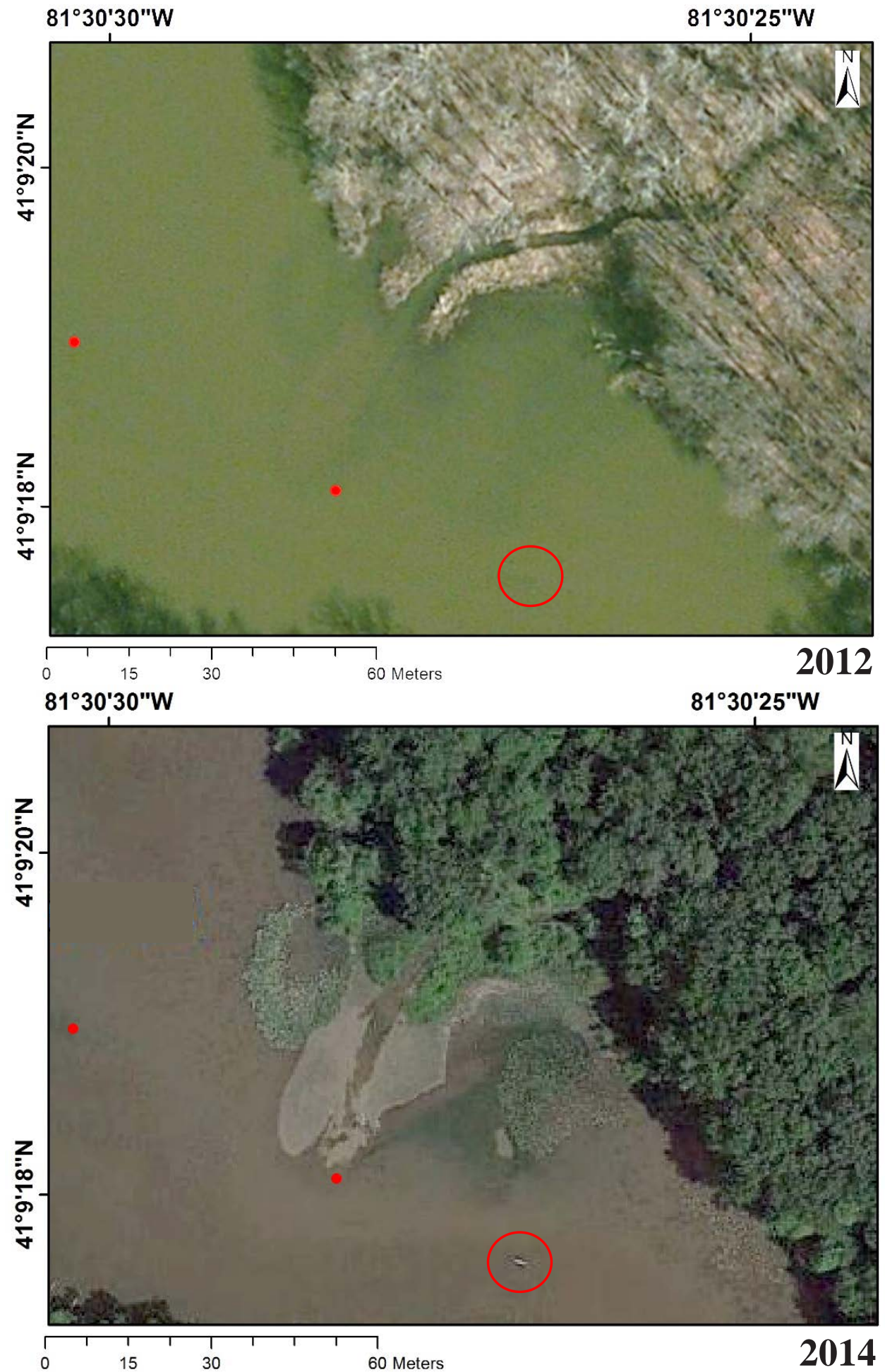

Figure 56. Old Mill Pond delta in 2012 and 2014. The leftmost red dot is the OMP-16-C3 core location and the rightmost dot is the OMP-16-C5 core location. The feature within the red circle is a stationary object used determine relative water level change (Google, 2016; Summit County Fiscal Office, 2016). 

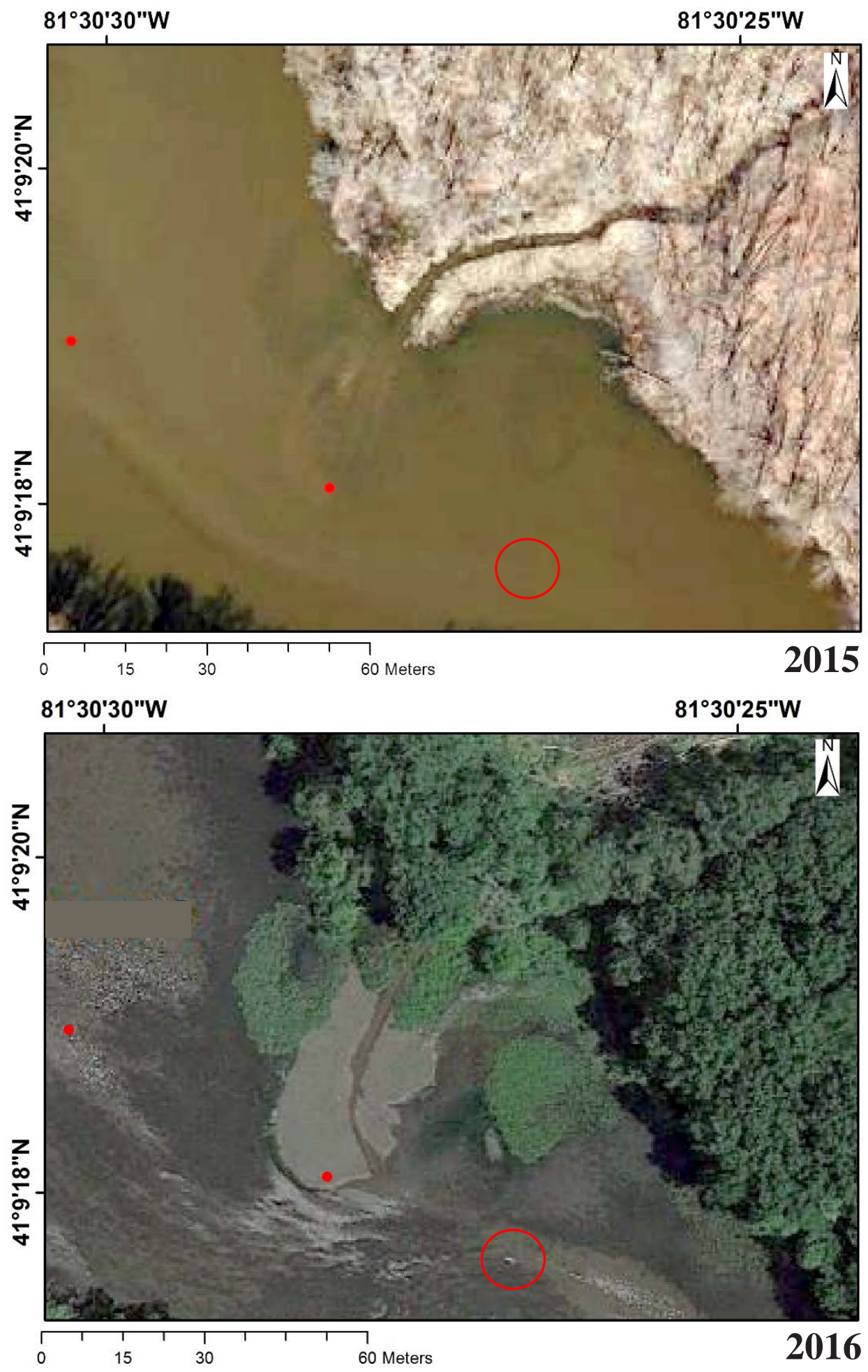

Figure 57. Old Mill Pond delta in 2015 and 2016. The leftmost red dot is the OMP-16-C3 core location and the rightmost dot is the OMP-16-C5 core location. The feature within the red circle is a stationary object used determine relative water level change (Google, 2016; Summit County Parcel Viewer, 2016). 
Table 30. Lake water level relative to the concrete structure in Old Mill Pond.

\begin{tabular}{cc}
\hline \hline Year & Water Level \\
\hline 1994 & Shallower \\
2000 & Deeper \\
2003 & Shallower \\
2005 & Shallower \\
2006 & Deeper \\
2010 & Deeper \\
2012 & Deeper \\
2014 & Shallower \\
2015 & Deeper \\
2016 & Shallower \\
\hline
\end{tabular}


were measured for magnetic susceptibility and plotted below $2 \%$ frequency dependence indicating the absence of SPM grain sizes.

\subsubsection{Shoreline Change}

The deltaic area of a small stream entering the east side of the impoundment was observed on aerial photographs between 1994 and 2016 (Figures 53-57). A stationary object present in the impoundment observed in 1994, 2003, 2005, and 2014 was utilized to assess lake level changes (Table 30). Lake level variation made it difficult to detect if the delta has prograded over time. Prior to 2003, however, the inflow was directed to the south, whereas post-2003, the inflow and delta sedimentation was directed to the west.

\subsubsection{Land cover}

Land cover area, land cover area change, impervious cover, and impervious cover change were tabulated and analyzed for the Mud Brook subwatershed containing Old Mill Pond (Figure 58; Table 31; Appendix E). The total area of the Mud Brook watershed is 8,439,300 $\mathrm{m}^{2}$. Between 1985-2010, there was an 15.3\% overall increase in developed land (+1,291,500 $\left.\mathrm{m}^{2}\right)$, a 13.05\% decrease of undeveloped land (-1,101,600 $\left.\mathrm{m}^{2}\right)$, and a $2.21 \%$ decrease in farmland $\left(-186,300 \mathrm{~m}^{2}\right)$. The greatest land cover change over the 25-year period occurred between 1996-2001, with a decrease in undeveloped land by 7.28\% (-614,700 $\left.\mathrm{m}^{2}\right)$, a decrease in farmland by $0.15 \%\left(-12,600 \mathrm{~m}^{2}\right)$, and an increase in developed land by 7.44\% (+628,200 $\left.\mathrm{m}^{2}\right)$. The impervious surface data shows that from 1985-2010, there was an overall increase in impervious area of $467,583 \mathrm{~m}^{2}$ (5.54\%) of the Mud Brook watershed. As of 2010, the Mud Brook watershed has 74\% developed land cover, 3.2\% farmland, and 22\% undeveloped land cover. Of the total watershed, $24 \%$ is impervious surface, mainly attributable to developed land cover. Most of the developed land cover is from housing and shopping centers built within the Mud Brook watershed. 

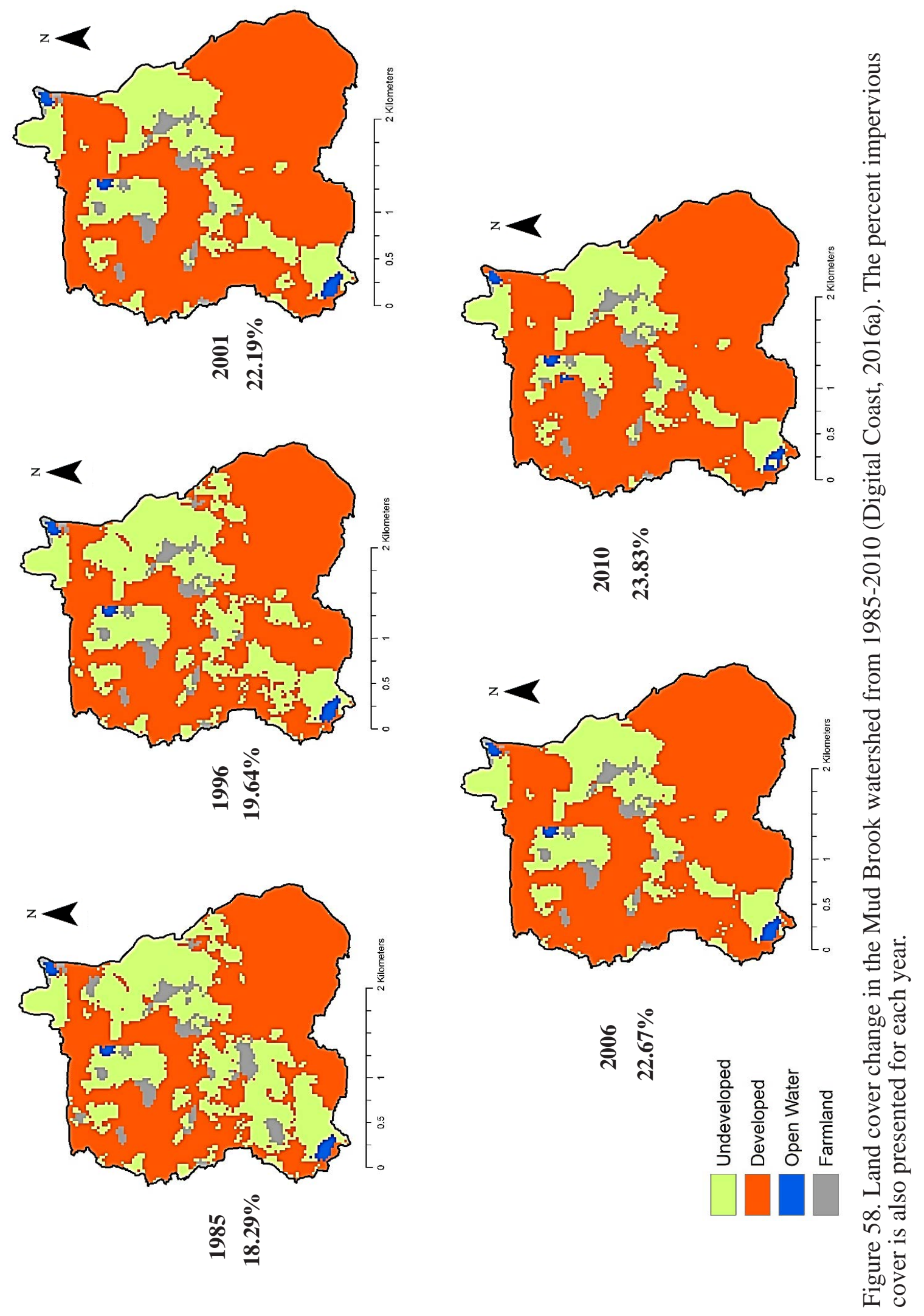


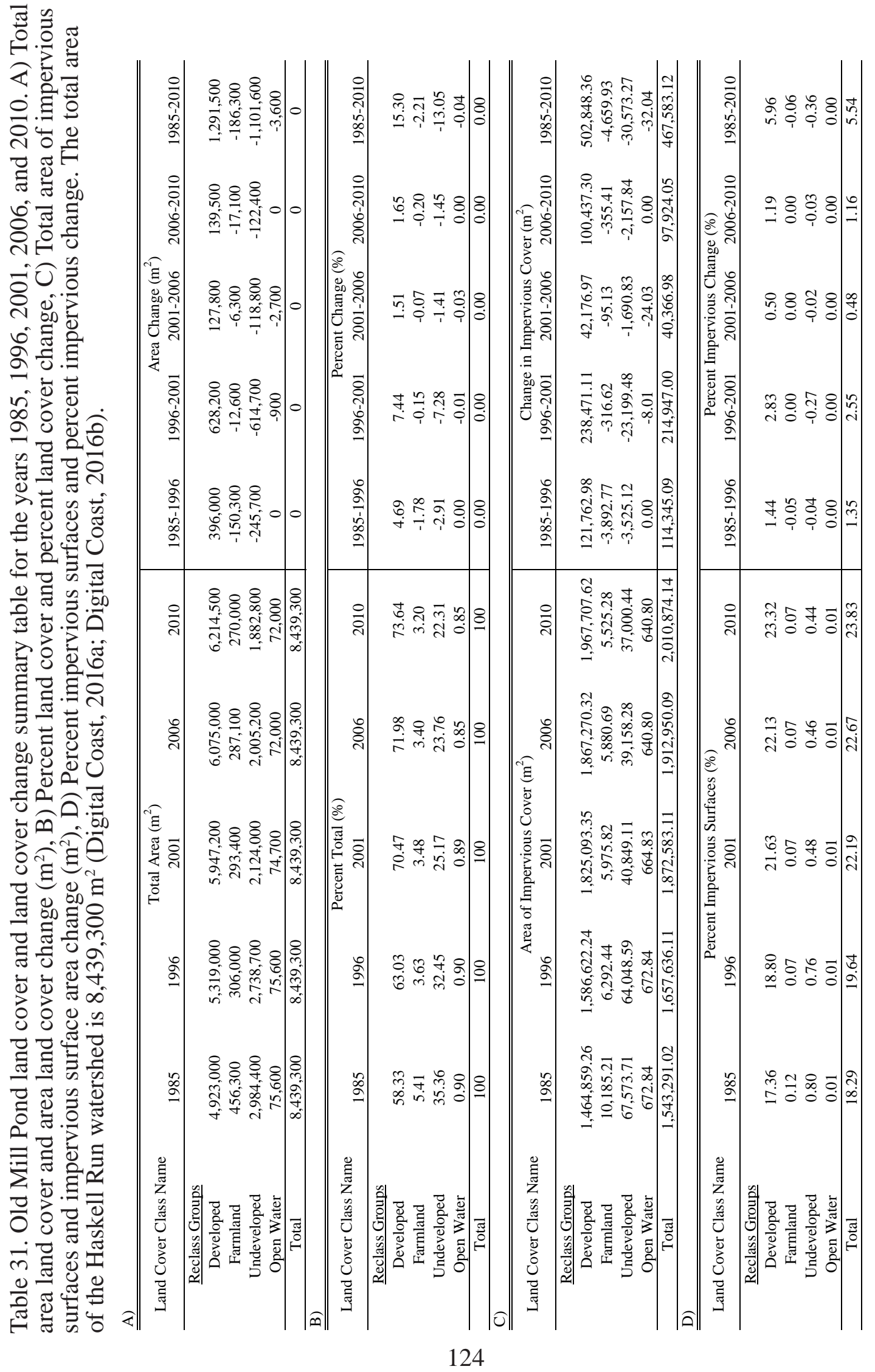


The small section that has consistently remained undeveloped over time lies along Mud Brook (Figure 58). This area is likely subject to flooding and therefore is unsuitable for development. 


\section{CHAPTER IV}

\section{DISCUSSION}

\subsection{The Impact of Watershed Development on Pollution in Fluvial Systems}

My first hypothesis states that the sediments from Old Mill Pond, located in the urban Mud Brook watershed, would have greater heavy metal and ferrimagnetic particle concentrations than sediment from Lakes Butler and Litchfield located in rural Haskell Run and Ritchie Run watersheds. As of 2010, the land cover data reveals that the Mud Brook watershed has 74\% developed land cover, whereas Haskell Run has 12\% and Ritchie Run has 3\% (Tables 20, 25, and 31; Appendix E). The impervious surfaces of Mud Brook, Haskell Run, and Ritchie Run are 24\%, 5\%, and 2.4\%, respectively. Furthermore, as of 2012, the population in the Mud Brook watershed is approximately 5,757 people, whereas Haskell Run and Ritchie Run have a combined population of approximately 672 people (U.S. Census Bureau, 2012). Owing to the contrasting watershed development, these sites provide ideal locations to test the above-mentioned hypothesis.

Heavy metals tested for this project were lead, zinc, copper, and chromium, all of which are commonly associated with anthropogenic pollution. The surface samples and the uppermost $20 \mathrm{~cm}$ of sediment cores that were measured for heavy metal concentration are considered to represent present-day conditions. Old Mill Pond sediments have higher heavy mental concentrations of $\mathrm{Pb}, \mathrm{Zn}$, and $\mathrm{Cu}$ than Lakes Butler or Litchfield (Figure 59). The Cr concentrations are similar between the three impoundment sites. For all metals, Old Mill Pond sediment exhibited a wider range of metal concentrations than 

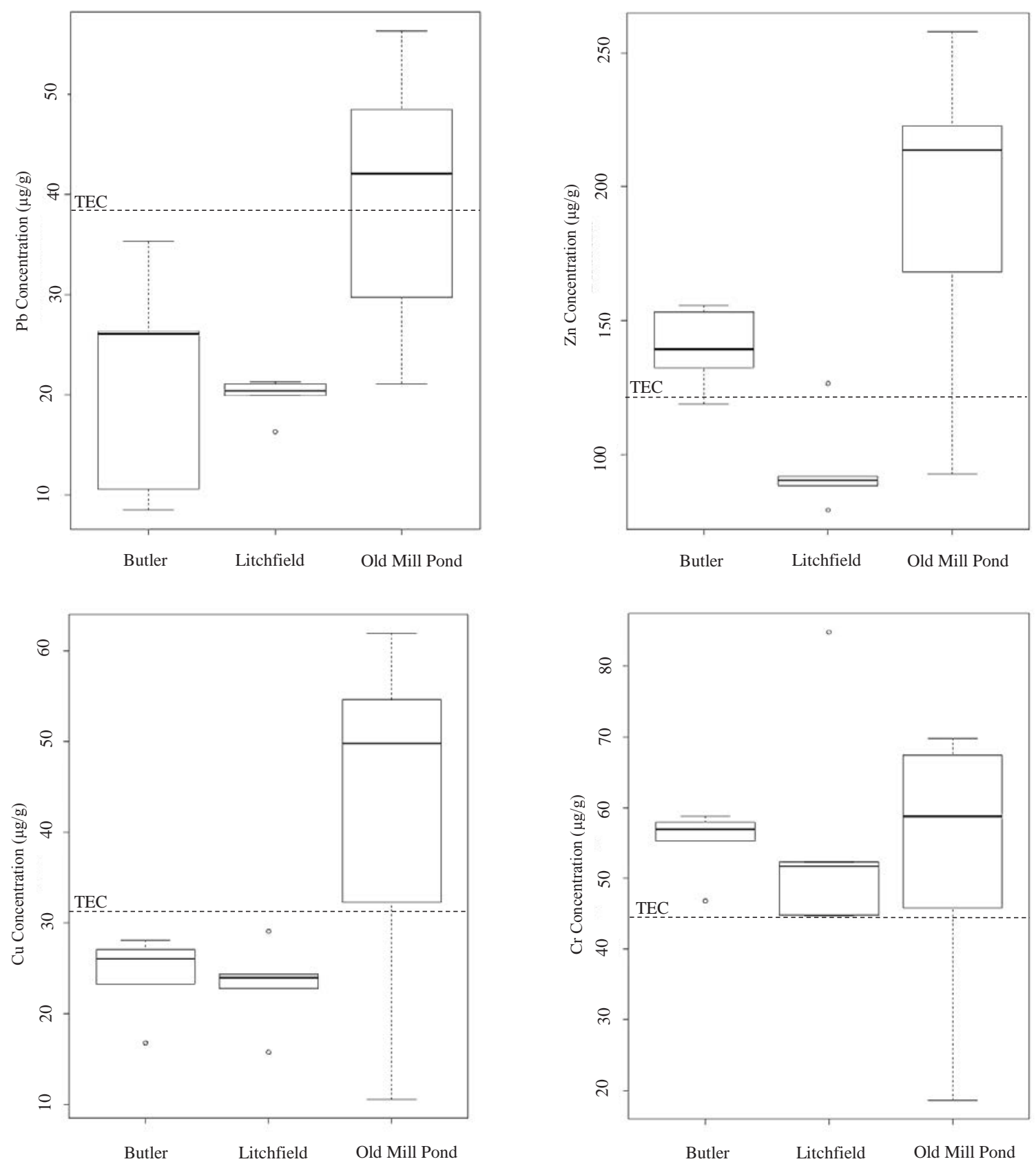

Figure 59. Box and whiskers plot of $\mathrm{Pb}, \mathrm{Zn}, \mathrm{Cu}$, and $\mathrm{Cr}$ heavy metal concentrations for Lake Butler $(n=5)$, Lake Litchfield $(n=5)$, and Old Mill Pond $(n=10)$. The consensusbased threshold effect concentration (TEC) for each metal are indicated by the dashed horizontal line (MacDonald et al., 2000). 
Lakes Butler or Litchfield. Both Lake Butler and Lake Litchfield sediment have similar and low heavy metal concentrations. These data support the hypothesis that Old Mill Pond sediment contains higher levels of anthropogenic heavy metal concentrations than the rural impoundments of Lakes Butler and Litchfield. The higher heavy metal concentrations in Old Mill Pond are attributed to increased watershed development and human activities adversely affecting the fluvial environment.

The consensus-based threshold effect concentration (TEC) and probable effect concentration (PEC) are toxicity levels on "sediment-dwelling organisms" of various pollutants in freshwater sediments (MacDonald et al., 2000). MacDonald et al. (2000) explain that TECs identify contaminant concentrations in freshwater sediments below which adverse effects on benthic organisms are unlikely, and "predict the absence of toxicity.” The PEC determines the level at which the toxicity of contaminant in the sediment will likely have "adverse effects on sediment-dwelling organisms” (MacDonald et al., 2000). None of the surficial sediment samples from the three impoundments approached the PEC for Pb, Zn, Cu, or Cr. Most samples from Old Mill Pond were between the TEC and PEC (Figure 59). Lakes Butler and Litchfield sediment samples were below the TEC for $\mathrm{Pb}$ and $\mathrm{Cu}$. For $\mathrm{Zn}$, Lake Butler samples were above the TEC, whereas Lake Litchfield was below the TEC. The majority of the samples from all of the impoundments were above the TEC for Cr.

When examining surface sediment Pb concentrations at Old Mill Pond, the highest lead concentrations are located either adjacent to the drainage pipe at the northeast corner of the lake or by the culvert toward the south end of the impoundment where the channel narrows (Figure 45). The drainage pipe and culvert receive runoff from roadways and parking lots. The higher $\mathrm{Pb}$ concentrations are thus likely related to increased pollution from these impervious surface areas. The Pb concentrations did not approach the PEC, however samples did surpass the TEC. 
Chromium naturally occurs in the earth's crust in oxidation states from $\operatorname{Cr}(\mathrm{III})$ to $\mathrm{Cr}(\mathrm{VI})$, where $\mathrm{Cr}(\mathrm{III})$ is the most stable and often found in the ore ferrochromite (Jacobs and Testa, 2005; Tchounwou et al., 2014). Industrial activity such as stainless steel welding, metal processing, and ferrochrome/chrome pigment production are common sources of Cr (VI) to the environment (Tchounwou et al., 2014). Interestingly, the surficial sediment $\mathrm{Cr}$ concentrations are similar at Old Mill Pond, Lake Butler, and Lake Litchfield (Figure 59). The average $\mathrm{Cr}$ concentration for all three impoundments is approximately $55 \mu \mathrm{g} / \mathrm{g}$ (Tables 17, 22, and 29). Other Northeast Ohio lake sediment research of Cr include studies of Silver Lake, Summit Lake, Rex Lake, and Brady Lake (Haney, 2004; Shaw, 2013; Mitchell, 2015; Grochocki, 2017). In sediment that accumulated prior to the Euro-American Settlement in Northeast Ohio, Cr concentrations range from 20 to $60 \mu \mathrm{g} / \mathrm{g}$, which reflect the natural background chromium concentration. Though on the higher end, the Cr concentrations for Old Mill Pond, Lake Butler, and Lake Litchfield are within the background concentration range for chromium. Therefore, the similar Cr concentrations at Old Mill Pond, Lake Butler, and Lake Litchfield likely represent natural sources of Cr rather than anthropogenic activity.

It can be concluded that urban watersheds generally have higher levels of heavy metals in impoundment sediments than in rural watersheds because heavy metal pollution is linked to greater anthropogenic activity and higher percentages of developed land cover and impervious surfaces. There is an established link between developed and agricultural land use as a source for higher non-point source pollution levels, whereas forests and grasslands typically have lower pollution levels (Shi et al., 2017). Copper is often used in plumbing and wiring (Smol, 2008). Zinc and lead are both present in coal-fired power plant emissions (Lee and Lehmden, 1973). Zinc is also found in galvanized metals and as an accelerator agent for the vulcanization process in tire manufacturing (Callendar and Rice, 2000). Lead is found in relatively low amounts naturally, but it is often associated 
with anthropogenic activity such as fossil fuel combustion, manufacturing, mining, and lead pipes for municipal water (Lee and Lehmden, 1973; Tchounwou et al., 2014). Lead shot-gun pellets and sinkers used in recreational hunting and fishing can also be a source for lead contamination especially if the ammunition and sinkers are left in the field (Haig et al., 2014). Located $1.46 \mathrm{~km}$ upstream of Old Mill Pond, was the former Mud Run Gun Club that had contaminated the soil with lead shot-gun pellets (Wiandt, 2010; Schleis, 2017). It is unknown if this upstream lead source has any influence on the lead concentration present in Old Mill Pond surface sediment.

Mitchell (2015) studied the sediment in Rex Lake, a kettle lake in Summit County, New Franklin, OH, in a rural area where the population density, as of 2015, is 1,096 people $/ \mathrm{mi}^{2}$. The population density in Cuyahoga Falls, where Old Mill Pond is located, is $1,925 \mathrm{people} / \mathrm{mi}^{2}$ (Census Bureau, 2015). In addition to having almost double the population, the Old Mill Pond watershed contains more developed land cover than the rural Rex Lake watershed. However, the Pb levels in Rex Lake surface sediment are slightly higher than Old Mill Pond surface sediment. Rex Lake modern day Pb sediment concentrations range from 42-94 $\mu \mathrm{g} / \mathrm{g}$ (Mitchell, 2015), whereas Old Mill Pond Pb modern day sediment concentrations range from 21-56 $\mu \mathrm{g} / \mathrm{g}$ (Table 31). Mitchell (2015) attributed the rise in lead concentration between 1900-1980 to increased lake recreation, the use of motorized boats, and the building of hotels and houses around the lake. In the Mud Brook watershed, impervious surfaces and development contribute anthropogenic pollution to Old Mill Pond; however, no boating occurs on Old Mill Pond. The variance in human activities, and not the population density in the watershed, may account for the differences in Pb concentration between Rex Lake and Old Mill Pond.

In summary, Old Mill Pond present-day heavy metal concentrations are between the PEC and TEC, indicating that the contaminants are not above the level for which there are adverse effects on benthic organisms, yet toxins are also not below the threshold 
of adverse effects (MacDonald et al., 2000). For Lakes Butler and Litchfield, $\mathrm{Pb}$ and $\mathrm{Cu}$ concentrations were below the TEC. Lake Litchfield Zn concentrations were well below the TEC, whereas Lake Butler exhibited higher levels of Zn above the TEC. Old Mill Pond, Lake Butler, and Lake Litchfield Cr concentrations were above the TEC and attributed largely to background sources.

\subsection{Sediment Magnetism as a Pollution Proxy}

Heavy metal analysis on sediment is instrumental for assessing pollution; however, the process is time-consuming and expensive. For this reason, sediment magnetism was studied to determine if magnetic parameters could be used as a heavy metal proxy. Anthropogenic pollution, such as combustion products from gasoline or coal, is often highly magnetic and produces ferrimagnetic particles that are distinct from naturally occurring pedogenic ferrimagnetic particles (Evans and Heller, 2003). Sediment magnetic properties have the advantage of being less time-consuming and inexpensive to measure.

Old Mill Pond sediment exhibits higher magnetic concentration compared to Lakes Butler and Litchfield (Figure 60). Magnetic susceptibility is generally considered a ferrimagnetic concentration parameter; however, susceptibility also depends on paramagnetic and diamagnetic content as well as the presence of superparamagnetic particles. Magnetic remanence parameters SIRM and $\chi \mathrm{ARM}$ only measure the remanence-bearing particles in a sample. The SIRM and $\chi \mathrm{ARM}$ measurements are similar to susceptibility in that greater values are found with Old Mill Pond sediment compared to Lakes Butler and Litchfield. The corresponding SIRM and heavy metal concentration values show a moderate direct relationship between ferrimagnetic and heavy metal concentration (Figure 61). Two sandy surface samples from Old Mill Pond (G7 and G8) were not plotted because all other samples were mud, and it is best not to mix 


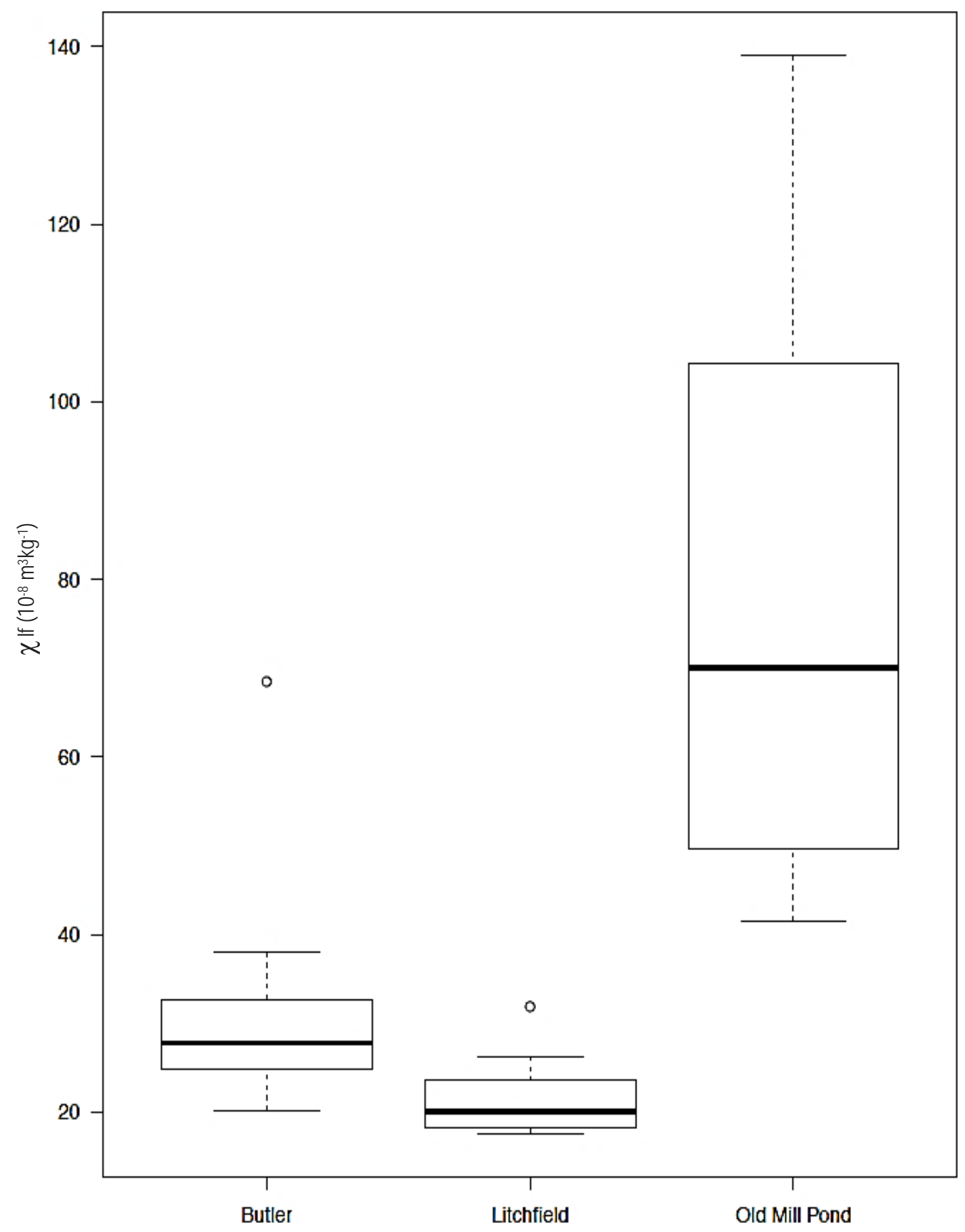

Figure 60. Box and whiskers plots of magnetic susceptibility $(\chi)$ ranges, a sediment magnetic parameter, for all surface samples for Lake Butler $(n=14)$, Lake Litchfield $(n=13)$, and Old Mill Pond $(n=13)$. 

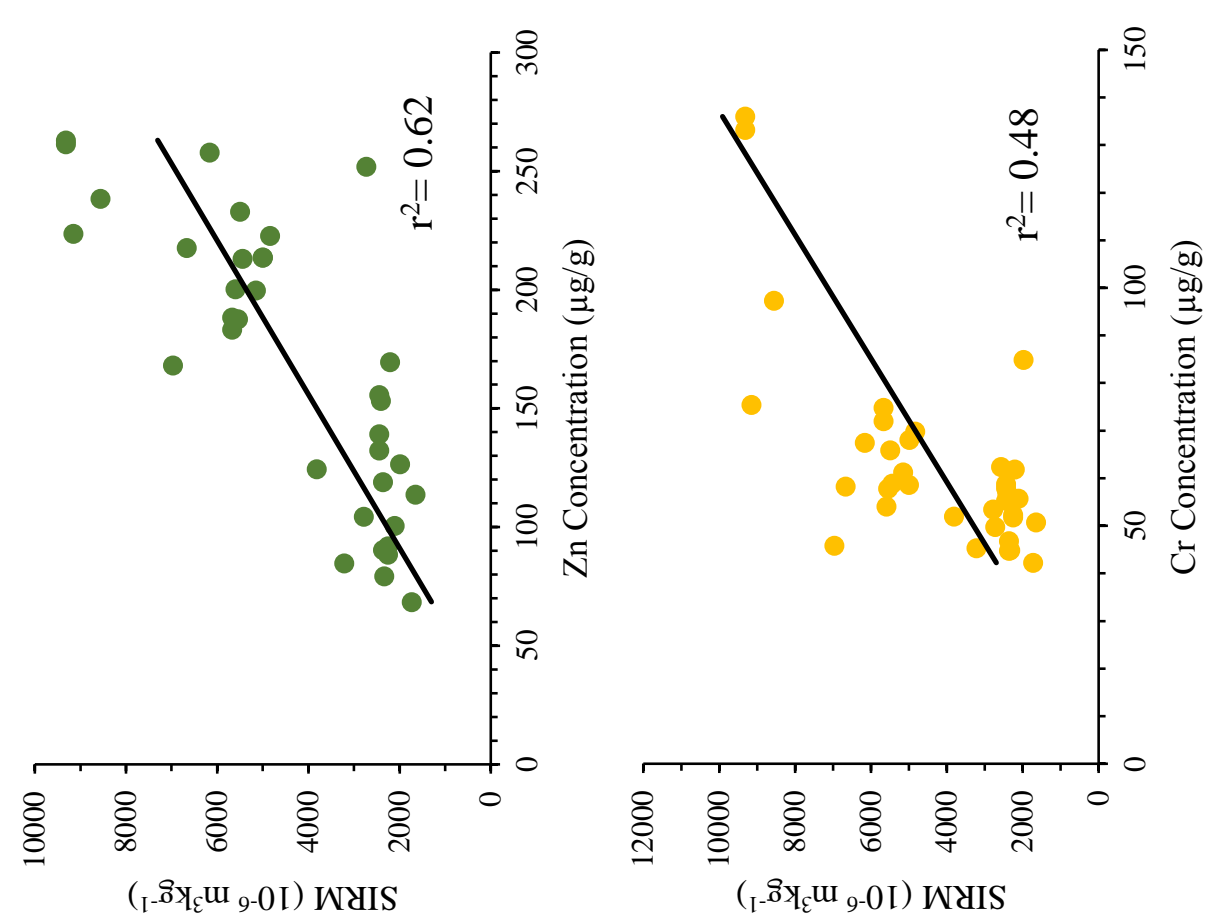

웅

U

งิ

ลิ

4

䜦

E 8

要

के

ติ

ปั

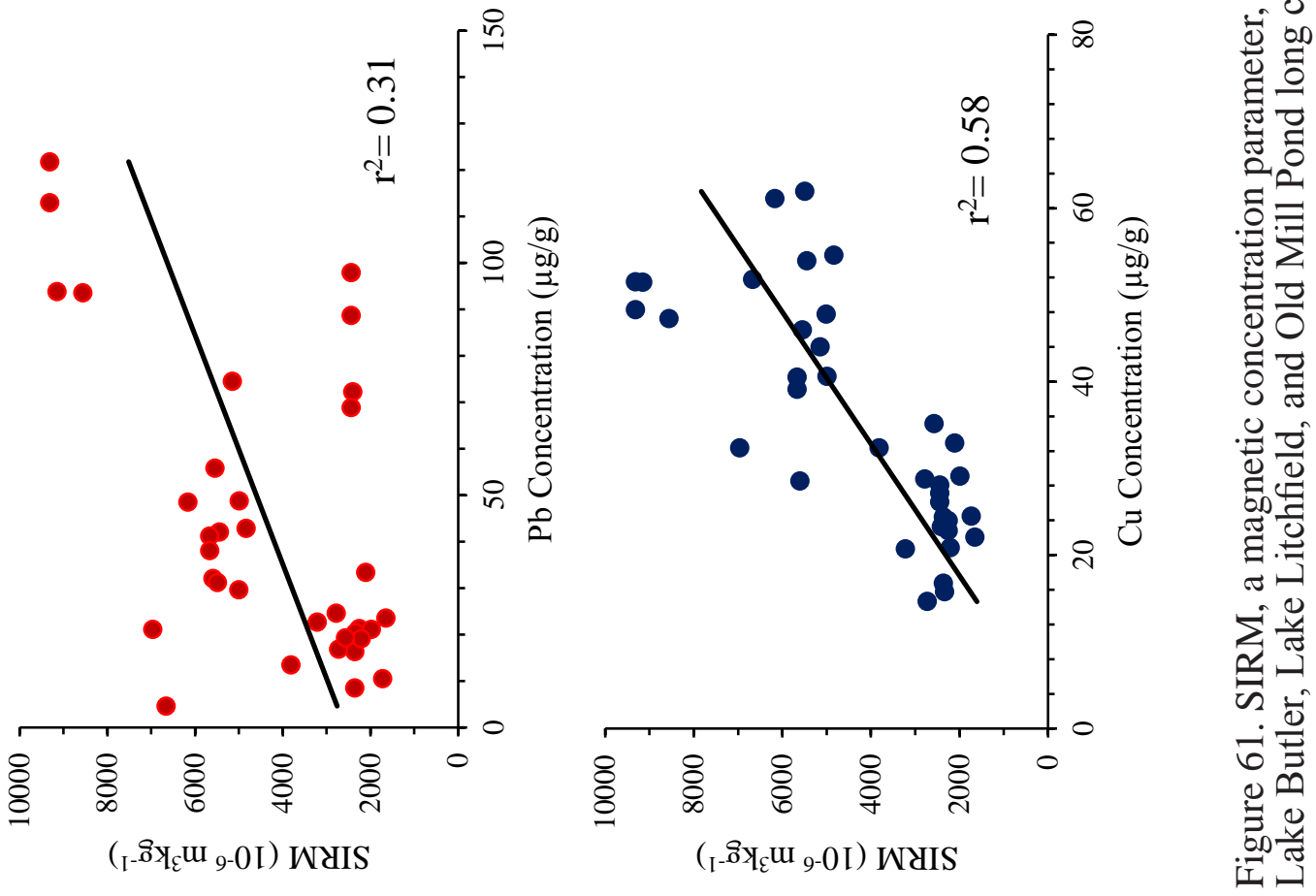


contrasting lithologies. Zinc $\left(r^{2}=0.62\right)$ and copper $\left(r^{2}=0.58\right)$ display a moderate positive relationship between metal concentration and SIRM, whereas chromium $\left(r^{2}=0.48\right)$ and lead $\left(r^{2}=0.31\right)$ had weaker relationships. These data show that the rapid and inexpensive magnetic concentration measurements can be used in a general way as a proxy for heavy metal concentration. However, given the scatter in the data of this study, some pollution "hot spots" will be missed by the magnetic proxy. Furthermore, certain high magnetic concentration readings will not exhibit elevations of heavy metal concentration. Therefore, magnetic parameters as a pollution proxy has limitations, but overall can provide a quick site assessment tool.

Sand characterizes the surface sediment in the culvert and where the impoundment narrows by the dam at Old Mill Pond (Figure 45). The sand accumulates in these higher velocity areas, whereas mud accumulates in the wider impoundment area that has relatively lower velocity. Coarse-grained ferrimagnetic material, such as steel from anthropogenic sources (e.g., cars and construction) can be washed into the culvert from the parking lots and roadways. Clay particles tend to adsorb heavy metals (Konhauser, 2007). Due to both adsorption and flow velocity processes, the sand in Old Mill Pond has higher ferrimagnetic particle concentrations but lower heavy metal concentrations.

Additional magnetic parameters were analyzed in an attempt to differentiate sediment sources for each impoundment. The frequency dependence of susceptibility has been utilized to distinguish pedogenic sources from pollution sources (Dearing, 1999; Figure 62). Samples that plot above $2 \%$ frequency dependence contain superparamagnetic particles often of pedogenic origin (Dearing, 1999; Evans and Heller, 2003). Samples with less than $2 \%$ frequency dependence do not contain superparamagnetic particles. High concentrations of coarse-grained magnetic particles, stable single domain (SSD), are often associated with fossil fuel combustion (Dearing, 1999). In addition, enhanced Ohio soils tend to have a frequency dependence of 4-5\% (Peck, 2017). 


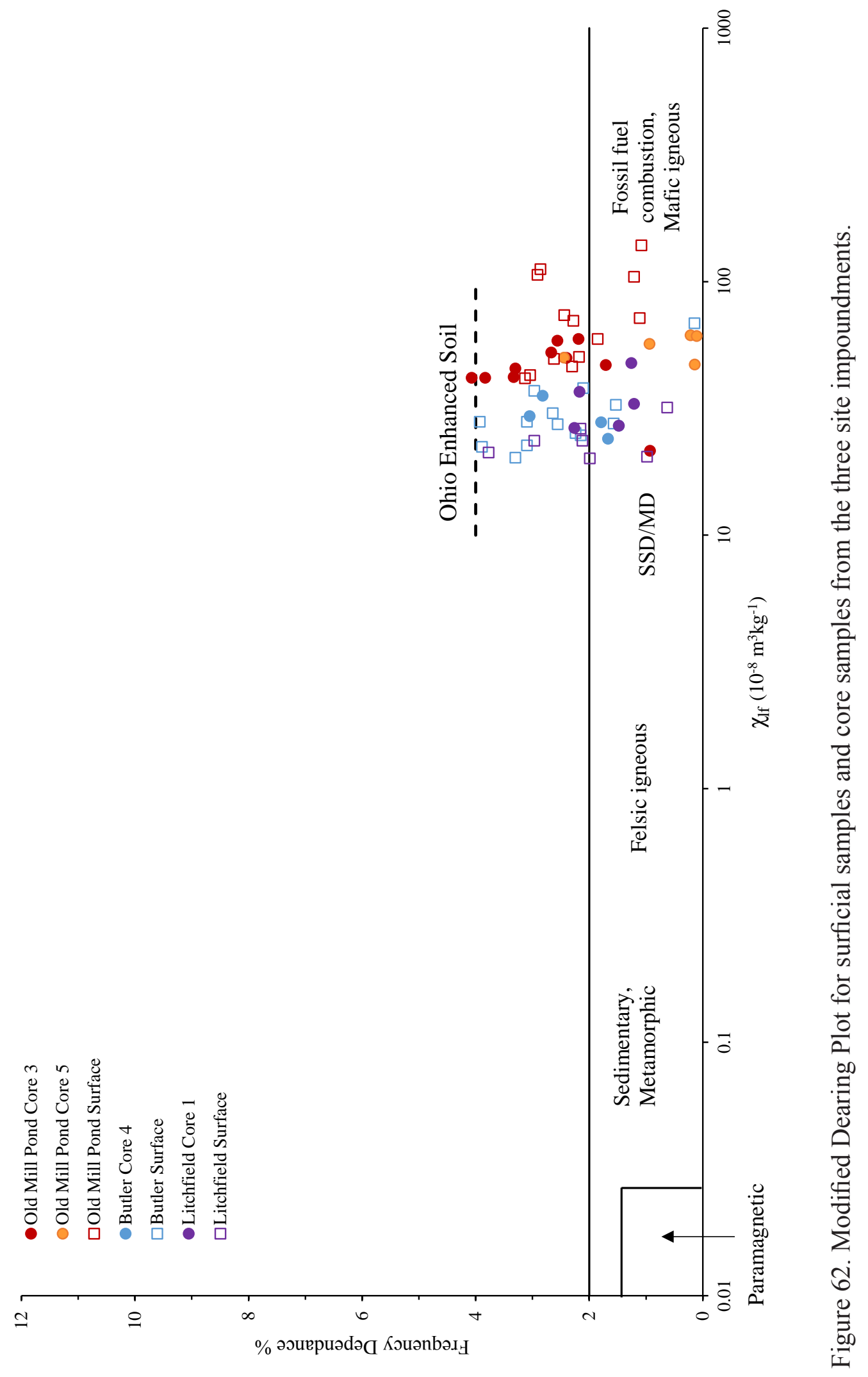


Of the 59 surface and core samples, 20 plot below the $2 \%$ line, and 39 plot above the $2 \%$ line (Figure 62). Of the 20 samples that plot below the $2 \%$ line, the samples from Old Mill Pond have higher concentrations of coarse-grained particles than Lakes Butler and Litchfield. The remaining 39 samples plot above the $2 \%$ line, indicating the presence of super paramagnetic (SPM) grains. These SPM grains may be pedogenically generated and washed into the impoundments. Alternatively, iron precipitation under oxic conditions can coat detrital mineral grains with magnetic minerologies having SPM size (Evans and Heller, 2003). Another possibility that explains the SPM grain sizes could be reductive diagenesis, which occurs in reducing conditions when iron oxids undergo dissolution and create iron sulfides. This process can dissolve larger SSD magnetic grains into smaller SPM grains. Evidence to support this possibility includes freshly split cores were black in color and smelled of hydrogen sulfide. Months later, the sediment cores turned brown and red suggesting the oxidation of mono-sulfide minerals.

Combustion often produces low coercivity (i.e., ferrimagnetic) particles. The S-ratio is an indicator of magnetic mineralogy. When S-ratio values are greater than 0.9 , ferrimagnetic minerals dominate the sample, whereas values less than 0.9 have a significant portion of high coercivity canted-antiferromagnetic particles (Evans and Heller, 2003). The S-ratio for all Old Mill Pond samples, except for one, are above 0.9 and indicate that ferrimagnetic minerals dominate the sediment at Old Mill Pond (Figure 50). Half of the Lakes Butler and Litchfield samples have S-ratios lower than 0.9 , indicating a high coercivity mineral assemblages, such as hematite staining detrital grains. 
4.3 Historical Changes Recorded in the Impoundment Sediment

Not only does the present-day surface sediment vary between urban Old Mill Pond and rural Lakes Butler and Litchfield, but there also are differences in the down core sediment profiles. In order to date approximate time intervals in the sediment cores, a linear sedimentation rate was established for each core by taking the impoundment sediment thickness (in $\mathrm{cm}$ ) and dividing it by the age difference between the year the dam was constructed and the year of core collection (2016). The resulting linear sedimentation rates for each lake are as follows: Lake Butler $=3.80 \mathrm{~cm} / \mathrm{yr}$, Lake Litchfield $=3.00 \mathrm{~cm} /$ yr, Old Mill Pond $=1.56 \mathrm{~cm} / \mathrm{yr}$. The Old Mill Pond core provides a record of pollution history in Cuyahoga Falls. The cores from Lakes Butler and Litchfield show their respective deltas prograding over time. All three impoundment cores have three time general periods: Pre-Dam Period, Early Impoundment Period, and Late Impoundment Period.

\subsubsection{Lake Butler}

The Pre-Dam Period for Lake Butler is pre-1962, the Early Impoundment Period is from 1962 to 1982, and the Late Impoundment Period is 1982 to 2016.

\section{Pre-Dam Period (pre-1962)}

Lake Butler lies within the rural watershed of Haskell Run. The Lake Butler dam was constructed between 1959-1962 (Bergdorf R., 2016). The linear sedimentation rate for core C4 is $3.80 \mathrm{~cm} / \mathrm{yr}$. Three general time periods (Pre-Dam, Early Impoundment, and Lake Impoundment) can be identified based on down-core sedimentary changes. The earliest time period, referred to as the Pre-Dam Period, is represented by the lowermost lithology unit in C4 (Figure 63). From 249 to $202 \mathrm{~cm}$ core depth, sand and gravel, displaying high dry bulk density and low organic matter, are present (Figure 63). The 


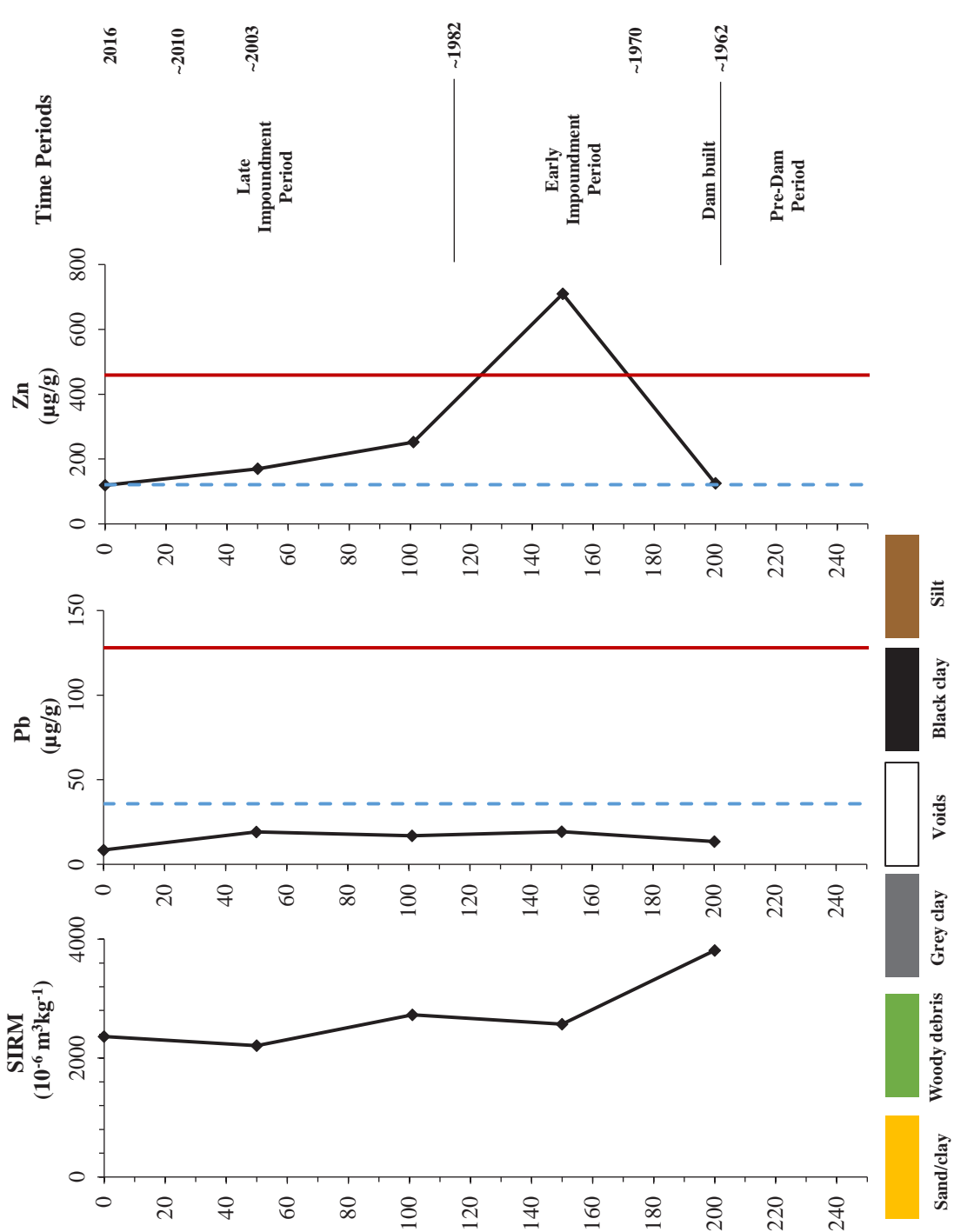

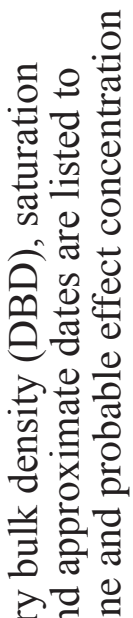

릉흘

के

응

:

. $\exists$ 두

मी

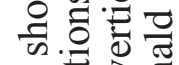

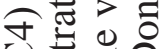

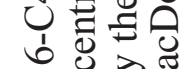

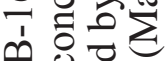

象守

Nㅓ엇

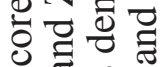

त

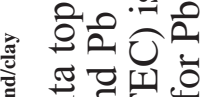

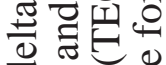

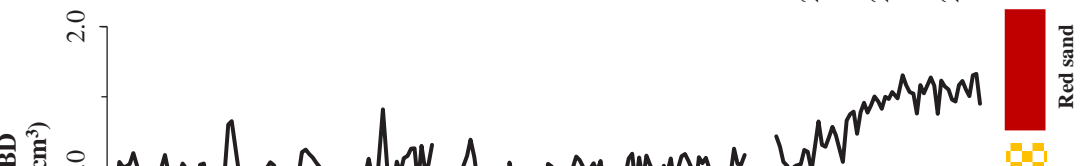

-

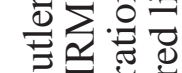
氙葛

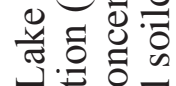

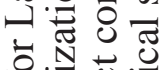
을 붕 윻

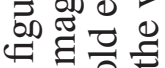

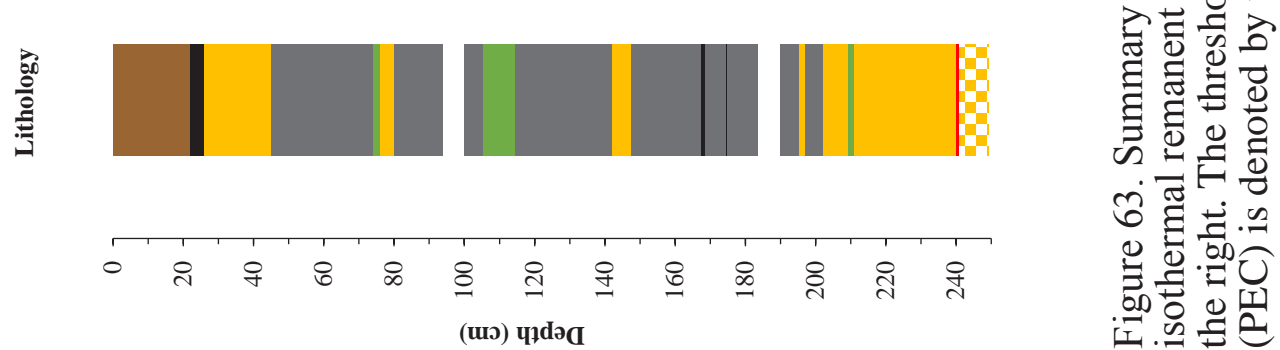


basal gravel indicates higher energy conditions similar to that observed in the presentday Haskell Run where gravels cover the channel floor (Table 6). Therefore, the basal gravel unit in the core is inferred to represent pre-dam conditions when the core site was a fluvial environment. The sand and gravel granules at the bottom of the delta top core (C4) are a similar size to the Haskell Run G13 sample collected upstream in a higher energy environment. The sand and gravel unit has an abrupt contact with an overlying clay lithology at $202 \mathrm{~cm}$.

\section{Early Impoundment Period ( 1962-1982)}

From 202-118 cm core depth, the lithology is predominantly a clay with moderate dry bulk density (Figure 63). The linear sedimentation rate dates this core interval to be approximately 1962 to 1982, which is referred to as the Early Impoundment Period. The clay lithology indicates a low energy depositional environment inferred to be the slackwater of the Lake Butler dam impoundment. During this time, the core site would have been located farthest from where Haskell Run entered the impoundment. The river mouth delta did not have the time to prograde into the lake at this point, and thus the clays were deposited in the low energy delta front environment. The sand layer from 147.5$142 \mathrm{~cm}$ may represent a flood event. In this time period, only two heavy metal samples were measured. Except for zinc, the heavy metal concentration values were low. Zinc, however, had a high concentration at $150 \mathrm{~cm}$ core depth (Figure 63).

In August 1981, a tire fire occurred in the Haskell Run watershed in Hudson, Ohio, upstream from Lake Butler (The Cleveland Press, 1981). News reports state that Haskell Run was exposed to a portion of the 9,000 gallons of tire oil resulting from the fire (Holies, 1981). However, the tire oil was said not to have affected Lake Butler (Holies, 1981). Given the great uncertainty in using a linear sedimentation rate to date the core, the high $\mathrm{Zn}$ concentration may or may not be temporally related to the 1981 tire fire. 
Future research could investigate in greater detail the $\mathrm{Zn}$ metal concentration and also analyze for other burned tire product chemical signatures surrounding the $150 \mathrm{~cm} \mathrm{Zn}$ peak to attempt to resolve the anomalously high $\mathrm{Zn}$ concentration. A sediment core could also be taken upstream in Haskell Run at a deposition center (i.e., floodplain marsh) to look for evidence of the tire fire.

\section{Late Impoundment Period (1982-2016)}

The sediment above $118 \mathrm{~cm}$ core depth represents the Late Impoundment Period. This period spans from 1981 to 2016. Above $118 \mathrm{~cm}$ core depth, the clay lithology is interbedded with sandy layers and woody debris layers (Figure 63). Dry bulk density in this section exhibits pronounced fluctuations. Heavy metal concentrations are generally low and declining toward the core top. The interbedded wood and sand lithologies appear to be a combination of two processes--flooding and delta progradation. At $50 \mathrm{~cm}$ core depth, there is a change from clay to a sandy clay mixture (Figure 63). In core C4 this depth dates approximately to 2003. This shift from clay deposited under low energy to sand deposited under high energy may be attributed to the increase in regional flooding after July 2003, as suggested by Liberator (2013) and Delaney (2016). The aerial photos do not show explicitly that after 2003 there was greater deposition of sediment at the delta mouth; however, delta progradation was occurring. The aerial photos from 1994 to 2016 show that the delta is prograding and that by 2010 the C4 core site transitions from delta front to delta top. The uppermost $22 \mathrm{~cm}$ of the core is a brown silt that accumulates in a delta top environment. As the delta prograded closer to the $\mathrm{C} 4$ core site, smaller flood events may be recorded in sediment record of $\mathrm{C} 4$ to a greater extent than when the delta is farther from the core site. This can be explained by the sediments being closer to the source, and thus more sediment can accumulate more rapidly. 

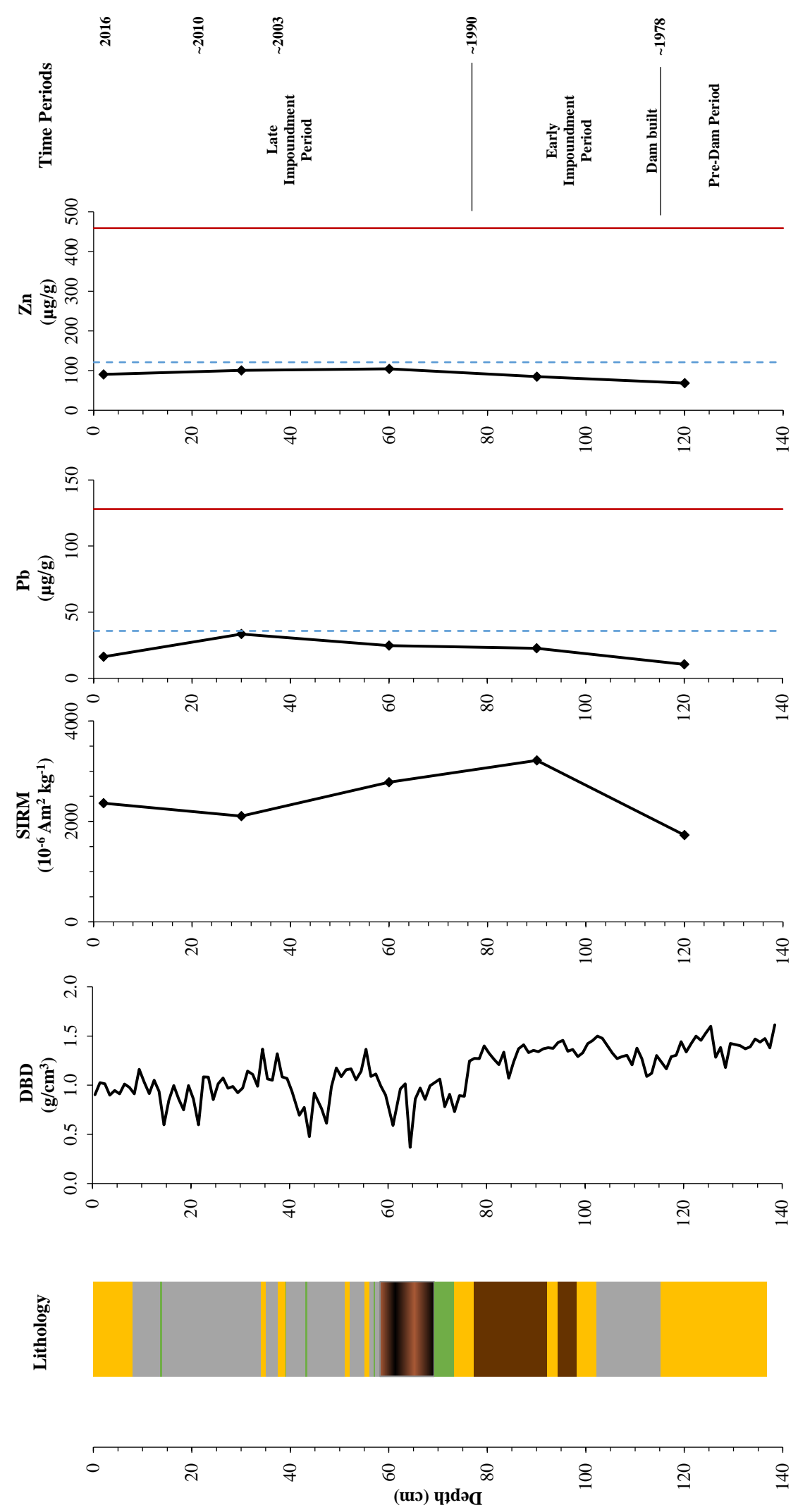

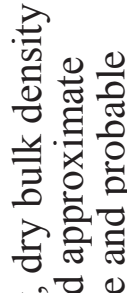

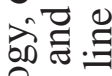

능

\& 0 d

‡

结娄

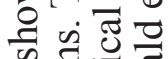

을

50

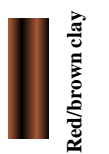

讨

号远

드음

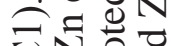

政

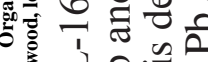

널웅

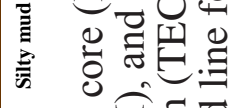

등

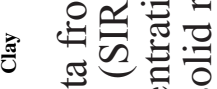

픙 छ क

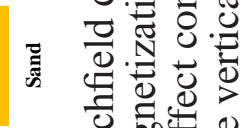

든

요음

ส

올 혈

के 원

的

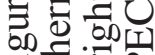

풍 민

ㄱ.?금

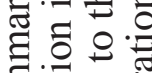

를

क

过芯

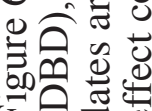




\subsubsection{Lake Litchfield}

The Pre-Dam Period for Lake Litchfield is pre-1978, the Early Impoundment Period is between 1978 and 1990, and the Late Impoundment Period is from 1990 to 2016.

\section{Pre-Dam Period (Pre-1978)}

Rural Ritchie Run contains the Lake Litchfield impoundment situated within the Manatoc Boy Scout Camp. The Lake Litchfield dam was installed between 1977-1978 (Bergdorf, R., 2016). The linear sedimentation rate for Lake Litchfield sediment core C1 was determined to be $3.00 \mathrm{~cm} / \mathrm{yr}$. Three general time periods can be identified based upon the down core sedimentary changes. The Pre-Dam Period is represented by the lowermost lithology unit in C1 (Figure 64). Between 139.5-118 cm core depth, sand with high dry bulk density is present. The sand unit implies deposition under high energy conditions and is interpreted to represent a riverine environment before the dam was constructed. At $118 \mathrm{~cm}$ core depth, there is an abrupt contact between the sand unit and the overlying clay unit. Early Impoundment Period (1978-1990)

The lithology from 118-78 $\mathrm{cm}$ core depth is predominantly clay and silt with interbedded sand layers (Figure 64). This period is referred to as the Early Impoundment Period and is estimated to span from 1978 to 1990 using the linear sedimentation rate. The mud layers indicate low energy associated with the slack water of the Lake Litchfield impoundment. The interbedded layers of sand indicating high energy conditions that are possibly associated with flood events. There is an increase in SIRM at $90 \mathrm{~cm}$ core depth, indicating greater ferrimagnetic concentration. Heavy metal concentrations are low in the Early Impoundment Period and throughout the entire core. 

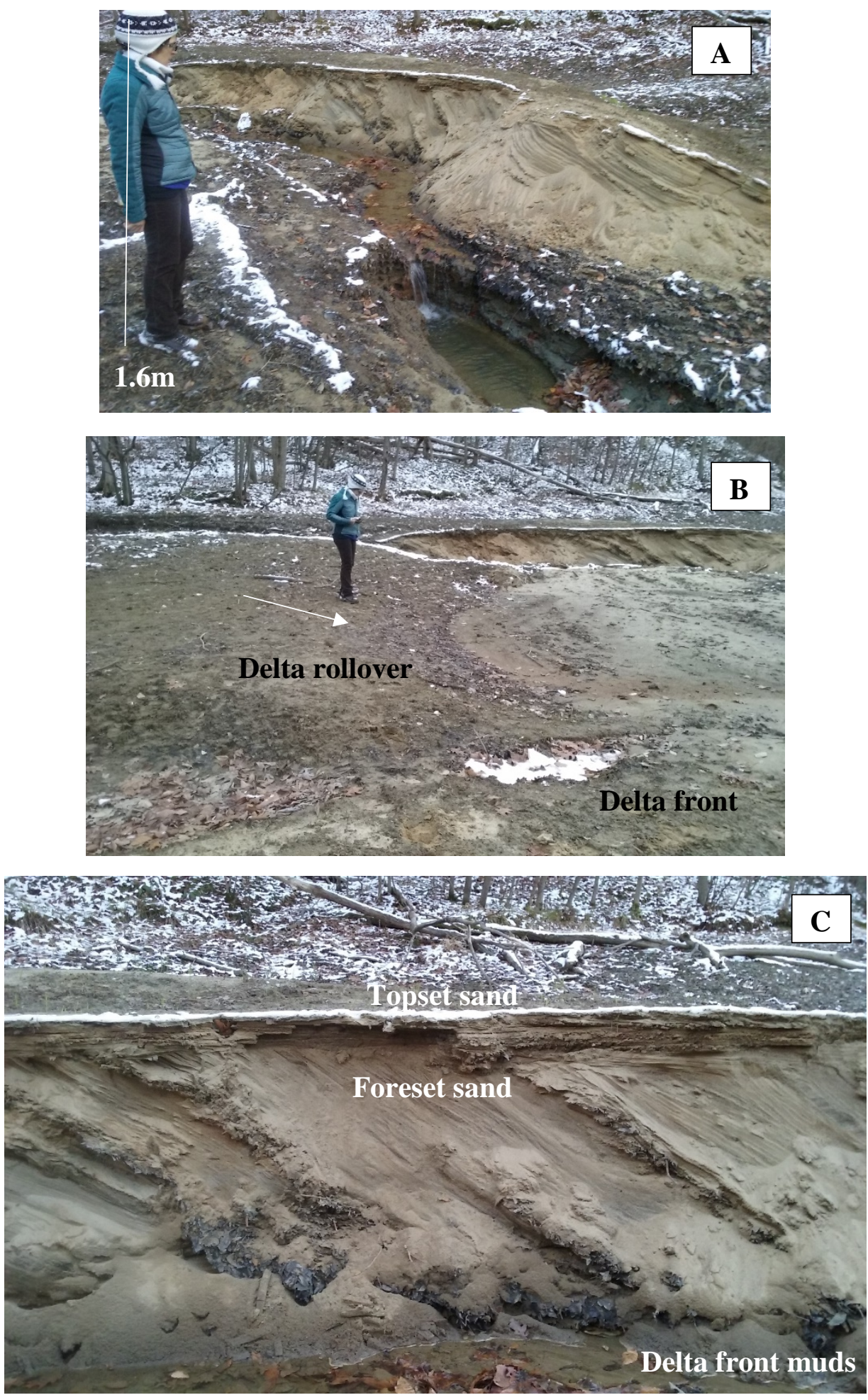

Figure 65. Sedimentary structures at Lake Litchfield delta on November 21, 2016. A) Longitudinal view of the subaqueous delta where core 2 was collected. B) The exposed delta rollover and delta front. C) Closer image showing the sedimentary structures of the topset/foreset contact. 
Late Impoundment Period (1990-2016)

The Late Impoundment Period, spanning from 1990 to 2016 is represented by the sediment above $78 \mathrm{~cm}$ core depth (Figure 64). The lithology is predominantly clay with interbedded sand and woody debris layers. Between $72-61 \mathrm{~cm}$, a red/black clay with highly variable in dry bulk density is present. Throughout the Late Impoundment Period, the dry bulk density profile shows pronounced fluctuations. The variations in dry bulk density and lithology is interpreted to represent flooding events as the delta progrades closer to the core site. Aerial photos from 1994 to 2016 indicate that the delta is prograding into the impoundment (Figures 39-43). The uppermost $8 \mathrm{~cm}$ of sand may be the result of increased regional flooding and the close proximity of the delta.

In August 2016, Lake Litchfield was drained to repair the outflow valve in the dam, which exposed the delta and core site C1. Deltaic sedimentary structures were readily observed at this time (Figure 65). The delta topset/foreset contact rollover show progradation as the delta at the mouth of Ritchie Run builds into the dammed impoundment over time. The water level in Lake Litchfield has not drastically changed since the dam was installed in 1978; therefore, the prograding delta reflects the decrease in stream energy as Ritchie Run enters the wide dam pool. At the exposed subaqueous delta and in core C2, layers of leaves were observed (Figures 64 and 65). According to Bilby and Heffner (2016), leaf-litter travel distance depends largely on wind speed in addition to forest age, tree type, and topography of the riparian area. The leaf layers may represent leaves washing downstream each fall and possibly during high flow events. To determine if leaf layers in the impoundment delta sediments have any chronostratigraphic or flood relevance, a monitoring experiment could be conducted using a marker to measure sediments over several years.

Water level and sediment supply are the two main factors that affect shoreline changes (Davison-Arnott, 2010). The lake level, until the late summer of 2016, had not 
changed drastically since the lake was dammed in 1978 (Bergdorf C., 2016). The aerial photos indicate a regressive shoreline, or prograding delta, building out into the lake since at least 1994 (Figures 39-43). The aerial photos were further analyzed to determine the progradation rate of the delta before and after 2003 (Table 26). The shoreline was expected to have a higher growth progradation after 2003, owing to the increase in flood frequency in Northeast Ohio. Two years were assessed before 2003 (1994 and 2000), and seven years were assessed after 2003 (2005, 2006, 2010, 2012, 2014, 2015, 2016). The pre- and post- 2003 progradation rates were $0.30 \mathrm{~m} / \mathrm{mo}$ and $0.32 \mathrm{~m} / \mathrm{mo}$, respectively (Table 28). Thus, the delta in Lake Litchfield did not appear to respond to the increased flood frequency after 2003. Delaney (2016) studied a dammed impoundment within the Yellow Creek, Ohio, watershed that showed greater delta sedimentation after 2003 than prior to 2003. The Yellow Creek dam pool, however, was shallower than Lake Litchfield. It is possible that the deeper Lake Litchfield impoundment accounts for any increase in sediment supply in the subaqueous part of the delta that is not resolved in the aerial photographs. To determine the sedimentation in the subaqueous delta at Lake Litchfield, a volumetric sediment analysis could be conducted by collecting numerous cores at the subaqueous delta and quantifying the amount of sediment depositing at the delta over time.

\subsubsection{Old Mill Pond}

The Pre-Dam Period for Old Mill Pond is pre-1920, the Early Impoundment Period is from 1920 to 1971, and the Late Impoundment Period is 1971 to 2016.

\section{Pre-Dam Period (Pre-1920)}

Old Mill Pond is a small impoundment that lies within the Mud Brook watershed. The Old Mill Pond dam was constructed between 1910-1936, which for this thesis 


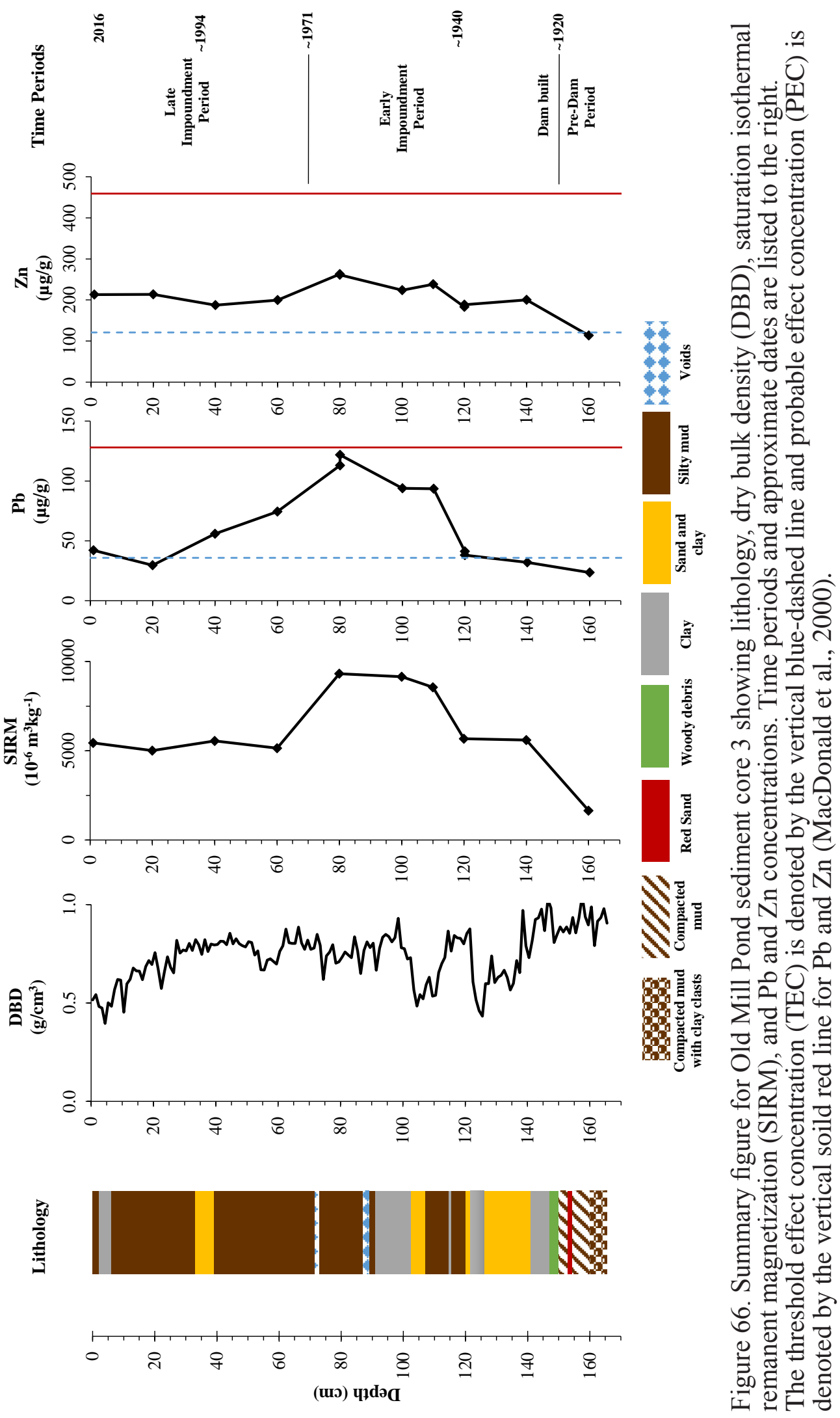


is approximated as 1920 (The Rectigraph Abstract and Title company, 1910; Sidwell Studio, 1936). A linear sedimentation rate was determined for Old Mill Pond to be 1.56 $\mathrm{cm} / \mathrm{yr}$. There are three general time periods (Pre-Dam, Early Impoundment, and Late Impoundment) that can be identified by sedimentary changes in C3. The earliest of these periods is the Pre-Dam Period, which is represented by sediment from 165.5 to 150 cm core depth (Figure 66). From 165.5 to $150 \mathrm{~cm}$ core depth, the main lithology is a compacted silty mud with decomposing leaves, wood, and roots. These sediments have high dry bulk density. In the lowermost $5.5 \mathrm{~cm}(165.5-160 \mathrm{~cm})$, there are small clay clasts present, which may indicate an erosion boundary in a fluvial environment. One heavy metal and SIRM sample were tested from this period and were found to be the lowest in the entire core (Figure 66). The boundary between the Pre-Dam Period and the Early Impoundment Period is marked by the increase in ferrimagnetic and heavy metal concentrations and a lithology change from compacted mud to organic-rich clay at 150 cm (Figure 66).

Early Impoundment Period (1920-1971)

From 150-70 cm core depth, the lithology is interbedded mud and sand, with a fluctuating dry bulk density (Figure 66). The Early Impoundment Period spans from 1920 to 1971 as determined by the linear sedimentation rate. The clay unit between 150-140 cm core depth indicates a change in environments from a possible wetland (muds with roots) to the slack water of the Old Mill Pond dam impoundment. Between $150-70 \mathrm{~cm}$ core depth, $\mathrm{Pb}$ concentrations increase to a maximum of $121 \mu \mathrm{g} / \mathrm{g}$ at about 1965 (80 cm). Between the 1940s-1960s, the city of Cuyahoga Falls experienced a doubling in population from about 25,000 to 50,000 (Mann et al., 2013). Approximately $1.46 \mathrm{~km}$ upstream of Old Mill Pond, the Mud Run Gun Club was located and resulted in lead contamination of the soil from spent ammunition (Wiandt, 2010). The historical activity 
of the gun club is unknown, but it ceased operation in the 1990s (Wiandt, 2010). The increased population, urban expansion, and change in watershed activities are likely to account for the increased level of pollution in the Old Mill Pond sediment core. The sand layers within the Early Impoundment Period may be related to increased erosion from the construction that accompanied the population growth, or they may have been deposited during high flow events.

\section{Late Impoundment Period (1971-2016)}

The Late Impoundment Period is represented by sediment above $70 \mathrm{~cm}$ core depth. The period spans from 1971 to 2016. In this time period, the lithology is predominantly a silty mud with moderate dry bulk density deposited in the low energy slack water of the dam impoundment (Figure 66). Sand and organic debris is interbedded within this section possibly as a result of a flood. This period is also characterized by a decline of heavy metals and ferrimagnetic particles, possibly due to changing watershed activities and the enactment and enforcement of the Clear Air Act (1970) and Clean Water Act (1972). The time series of aerial photos from 1994 to 2016 do not show significant changes accounted for by the increase in regional flooding after 2003.

\subsection{Broader Implications for Sedimentation, Land Use, and Climate Change}

In parts of the United States, such as the upper Midwest, the intensity of storms and resultant floods have noticeably increased in the last century (Pielke, 2005; Liberatore 2013; Schillereff et al. 2014). A local resident, Tom Quick, of Peninsula, OH, observed a major flood in July 2003 that caused notable damage to infrastructure in the area around Lakes Butler and Litchfield. Since then, Mr. Quick has observed an increase in flooding that often undermines the Cuyahoga Valley Scenic Rail Road train tracks and washes out 
roads and trails within Cuyahoga Valley National Park (Quick, 2017). The USGS stream gage station at Old Portage on the Cuyahoga River records the increase in flooding events since July 2003 (Figure 13). In addition to floods, there has been a marked change in the sediment load of the Cuyahoga River. Mann et al. (2013) document the increased Cuyahoga River sediment load associated with more frequent floods after July 2003. Wolman (1967) suggests that land use changes also impact sedimentation and fluvial channel morphology. The increase in urban land cover in the Mud Brook watershed from 1985 to 2010 is likely to continue given the building of proposed new shopping centers and housing developments. The Haskell Run/Ritchie Run watersheds are likely to maintain their undeveloped land cover because the watersheds lie within the boundaries of Cuyahoga Valley National Park. However, the less developed watersheds will still be at risk for more flooding damage with any increase in regional flooding. With more impermeable surfaces in urban watersheds and more frequent storms, the consequences will ultimately be higher volumes of runoff and greater flooding. Anticipating and planning the effects of increased urban development and flooding is a necessity in Northeast Ohio for the safety of people and infrastructure, and for the preservation of vital ecosystems such as wetlands, forests, and waterways (Cook et al. 2014; Stapanian et al. 2016).

Techniques to manage high sediment yields or contaminants spreading throughout the Cuyahoga River watershed should focus on protecting current wetlands in addition to constructing wetlands to trap sediment, sustain forested areas, reduce impervious surfaces, and prevent further erosion especially in incised banks. Dammed impoundments capture a stream's sediment load and limit sediment and associated pollutants from traveling downstream. When dam pools reach sediment storage capacity, the stream sediment load bypasses the impoundment and impacts downstream ecosystems. Lakes Butler (6.4 m deep) and Litchfield (11 m deep) have large dam pools, therefore exceeding 
the sediment storage capacity will not be a problem in the foreseeable future. This inference is supported by limited sediment accumulation observed in Lake Litchfield when the lake was drained in 2016. Old Mill Pond, however, is only $1.4 \mathrm{~m}$ deep and sediment bypass is likely occurring. Wetlands and retention ponds being built around Old Mill Pond are therefore critical to limiting sediment from entering Mud Brook. Wetlands also provide natural bioremediation, including treatment of municipal waste-water effluent, a common cause of urban point-source pollution in fluvial systems (Konhauser, 2007; Ghermani and Fitchtman, 2015; Lane et al., 2016).

Assessment of the differences in sediment yield and sediment type loading into the Cuyahoga River is of value for land managers, local governments, citizens, and scientists, especially those involved with habitat preservation, sediment pollution prevention, and dredging of the Port of Cleveland. Cuyahoga Valley National Park (CVNP) is a land conservation agency committed to ecosystem preservation in the Cuyahoga River Valley (Hamin, 2001). Local waterways surrounding CVNP and the Cuyahoga Valley have experienced higher sediment delivery from increased regional flooding since 2003 (Mann et al., 2013; Liberatore, 2013).

There is a growing need in urban societies for assigning a "value" to the landscape to further illustrate habitat importance. Song et al (2015) suggest that conducting an "economic valuation" assessment with various land-use types might be useful in convincing governments and citizens to take note of their green space and the importance of habitat preservation now and in the future. 


\section{CHAPTER V}

\section{CONCLUSIONS}

This study of Lake Butler, Lake Litchfield, and Old Mill Pond sediment and watershed land cover determined the following:

- Heavy metal and ferrimagnetic concentrations are higher in the sediment of urban Old Mill Pond than in the sediment of rural Lakes Butler and Litchfield. As of 2010, Mud Brook had the highest percentage of developed land cover (74\%), whereas Haskell Run and Ritchie Run has 12\% and 3.4\% developed land cover, respectively. In the down core sediment profile of Old Mill Pond, the heavy metal concentration values increased and peaked between the 1940s-1960s during the time of major population growth in the city of Cuyahoga Falls. Since the early 1980s, there is a decrease in heavy metal concentration to the top of the core after the enactment and enforcement of the Clear Air Act (1970) and Clean Water Act (1972). In addition, changing land use and anthropogenic activity (e.g., presence of a gun club) may also contribute to the changing $\mathrm{Pb}$ concentration.

- A direct relationship was found between heavy metal and ferrimagnetic concentrations. Zinc $\left(r^{2}=0.62\right)$ and copper $\left(r^{2}=0.58\right)$ display a moderate positive relationship, whereas chromium $\left(r^{2}=0.48\right)$ and lead $\left(r^{2}=0.31\right)$ had weaker relationships. Magnetics can generally be used as a pollution proxy; however, due to the scatter of the data, some samples with low magnetic concentration could have high metal content, and other samples with high magnetic content could have low metal concentrations.

- Following the increase of flood frequency beginning in 2003, there is no apparent increase in the progradation rate of the subaerial delta top building into the impoundment. However, a future study of changes in the sediment accumulation of the subaqueous 
delta environment may provide a more accurate measure of the watershed response to increased flooding. The sediment cores from Lakes Butler and Litchfield become coarsergrained at the top because the prograding delta brought the sediment source closer to the core site. 


\section{REFERENCES}

Anderson T.W., Heil Jr. C.W., Gareau P.L., 2012, Lake levels in the Erie Basin of the Laurentian Great Lakes, J Paleolimnol., v. 47, p. 493-511.

Bergdorf C., Camp Manatoc and Butler Director, Interview with Andrea Rocchio, Personal Interview, December, 2016.

Bergdorf R., Peninsula Library Historian, Interview with Andrea Rocchio, Personal Interview with Andrea Rocchio, March and April, 2016.

Bilby R.E. and Heffner J.T., 2016, Factors influencing litter delivery to streams: Forest Ecology and Management, v. 369, p. 29-37.

Caldwell Scott, Camp Manatoc Ranger, Interview with Andrea Rocchio, Personal Interview, April, 2016.

Church M., Ferguson R.I., 2015, Morphodynamics: Rivers beyond steady state, Water Resour. Res., v. 51, p. 1883-1897.

Coakley J.P., 1999, Lake Levels in the Erie Basin: Driving factors and recent trends. NOAA, Proceedings of the Great Lakes Paleo-levels Workshop: The Last 4000 Years, Great Lakes Environmental Research Laboratory, p. 24-29.http://www.glerl.noaa.gov/ $\mathrm{ftp} /$ publications/tech_reports/glerl-113/tm-113.pdf

Cook C.N., Inayatullah, S., Burgman, M.A., Sutherland, W.J., Wintle, B.A., 2014, Strategic foresight: how planning for the unpredictable can improve environmental decision-making, Trends in Ecology and Evolution, v. 29, no. 9, p. 531-541.

Davidson-Arnott R., 2010, Introduction to Coastal Processes and Geomorphology: New York, Cambridge University Press, 442 p.

Davis W.R., 2013. Men of Schiff: A History of the Professional Scouters Who built the Boy Scouts of America. Lulu Press, Inc. p. 129-143

Dean W.E., 1974, Determination of carbonate and organic matter in calcareous sedimentsand sedimentary rocks by loss on ignition: Comparison with other methods, J. Sed. Petrol., v. 44, p. 242-248.

Delaney, A., 2016, Effects of climate and development on the hydrology and geomorphology of the Yellow Creek watershed, Summit and Medina Counties, OH, [Master of Science thesis]: Akron, The University of Akron, 235p. 
Digital Coast, 2016a, Coastal change analysis program regional land cover: http://coast. noaa.gov/digitalcoast/tools/lca (Accessed October, 2016).

Digital Coast, 2016b, C-CAP land cover classification scheme:http:/coast.noaa.gov/data/ digitalcoast/pdf/ccap-class-scheme-regional.pdf (Accessed November 2016).

Digital Coast, 2017, Impervious surface analysis tool: http://coast.noaa.gov/digitalcoast/ tools/isat (Accessed January, 2017).

Downing B., 1992, Park service, Boy Scouts negotiate over camps: Akron Beacon Journal. (In press).

ESRI, 2013, US Census population density: http://www.arcgis.com/home/item.html?id=3 02d4e6025ef41fa8d3525b7fc31963a Population_Density/MapServer (Accessed January 2017).

ESRI, World Imagery: ArcGIS - Online basemap (Accessed September, 2016).

ESRI, World Topographic Map: ArcGIS - Online topomap (Accessed October, 2017)

ESRI, 2012, US Census population density: http://server.arcgisonline.com/ArcGIS/rest/ services/Demographics/USA_Population_Density/MapServer (Accessed January 2017).

Evans M., Heller F., 2003, Environmental Magnetism: Principles and Applications of Enviromagnetics (first edition), Academic Press, San Diego, Elsevier Science, USA.

Folk R.L., 1980, A review of grain-size parameters. Sedimentology, v. 6, no. 2, p. 73-93.

Ghermandi A., Fichtman E. 2015. Cultural ecosystem services of multifunctional constructed treatment wetlands and waste stabilization ponds: Time to enter the mainstream? Ecological Engineering. v. 84, p. 615-623

Google, 2016, Google Earth (7.1.5.1557 ed.): http://www.google.com/permissions/ geoguidelines.html\#maps-print (Accessed January, 2016).

Grochocki J., 2017, Late Holocene environmental variability as record in the sediment of a Northeast Ohio Kettle Lake, [Master of Science thesis]: Akron, The University of Akron, 150p.

Hacker D.B., 2004, Cuyahoga Valley National Park, in Harris A.G., Tuttle E., Tuttle S.D., eds., Geology of the National Parks (sixth edition), Dubuque, IA, p. 164-190.

Haig S.M., D’Ella J., Eagles-Smith C., Fair J.M., Gervais J., Herring G., River J.W., and Schulz J.H., 2014, The persistent problem of lead poisoning in birds from ammunition and fishing tackle: American Ornithological Society, v. 116, no. 3, p. 408-428.

Hamin E.M., 2001, The US National Park Service’s partnership parks: Collaborative responses to middle landscapes, Land Use Policy, v. 18, p. 123-135.

Haney S.A., 2004, The sediment record of anthropogenic impact on the Summit Lake ecosystem: Akron, Ohio, [Master of Science thesis]: Akron, The University of Akron, $63 p$. 
Harnapp V.R., 1988, Land acquisition in the Cuyahoga Valley National Recreation Area, Land Use Policy, v. 5, no. 4, p. 307-374.

Henson R. and Montague C.S., 1981, Tire fire oil gets into lake at scout camp: Akron Beacon Journal (In press).

Hoffman I.H., N.D., The Story of Northampton Township, 1820-1970: Akron, Ohio, Northampton Historical Society and Media Action, 28p. (Accessed March, 2016).

Holies R., 1981, Tire blaze blackens northern Summit Skies: Akron Beacon Journal (In press).

Kibena J., Nhapi I., Gumindoga W., 2014, Assessing the relationship between water quality parameters and changes in landuse patterns in the Upper Manyame River, Zimbabwe, Physical and Chemistry of the Earth, v. 67-69, p. 153-163.

Konhauser K., 2007, Geomicrobiology: Blackwell Publishing Company. Malden. Blackwell Science Ltd.

Lacey E.M., King J.W., Quinn J.G., Mecray E.L., Appleby P.G., Hunt A.S., 2001, Sediment quality in Burlington Harbor, Lake Champlain, U.S.A., Water, Air, and Soil Pollution, v. 126, p. 97-120.

Lin B., Chen X., Yao H., Chen Y., Lie M., Gao L., James A., 2015, Analysis of landuse change impacts on catchment runoff using different time indicators based on SWAT model, Ecological Indicators, v. 58, p. 55-63.

Liberator S., 2013, Changes in geomorphic equilibrium on Furnace Run, Summit County, Ohio, [Master of Science thesis]: Akron, The University of Akron, 236p.

Love S., Giffels D., 1998, Wheels of Fortune: The Story of Rubber in Akron, Book 44, University of Akron Press, Akron. http://ideaexchange.uakron.edu/uapress publications $/ 44$

Jacobs J.A., Testa, S.M., Overview of chromium(VI) in the environment: background and history, In: Guertin, J.; Jacobs, JA.; Avakian, CP., editors. Chromium (VI) Handbook. Boca Raton, Fl: CRC Press, 2005, p. 1-22.

James L.A., 2013, Legacy sediment: Definitions and processes of episodically produced anthropogenic sediment, Anthropocene, v. 2, p. 16-26.

MacDonald D. D., Ingersoll C.G., Berger T.A., 2000, Development and Evaluation of Consensus-Based Sediment Quality Guidelines for Freshwater Ecosystems: Archives of Environmental Contamination and Toxicology, v. 39, p. 20-31. DOI: 10.1007/ s002440010075

Mann K.C., Peck J.A., Peck M.C., 2013, Assessing dam pool sediment for understanding past, present, and future watershed dynamics: An example from the Cuyahoga River, Ohio, Anthropocene, v. 2, p. 76-78.

Masek J., 1981, Scrap tire fire and oil spill are brought under control: The Cleveland Press (In press). 
Meiyappan P., Jain A.K., 2012, Three distinct global estimates of historical land-cover changes and land-use conversions for the past 200 years, Front. Earth Sci., v. 6, no. 2, p. 122-139.

Mitchell S., 2015, Sediment Dispersal Processes and Anthropogenic Impacts at Rex Lake, Summit County, Ohio, [Master of Science thesis]: Akron, The University of Akron, 216p.

Moon G., Civittolo D, 2015, Land Use and Geographic Population Distribution: Ohio State University Extension Office, https://extension.osu.edu/sites/ext/files/imce/About docs/Future Conversations/17\%20trends-land use and geographic population distribution.pdf (Accessed Dec. 2015).

Mueller E.N., Francke T., Battalla R.J., Bronstert A., 2009, Modeling the effects of landuse change on runoff and sediment yield for a meso-scale catchment in the Southern Pyrenes, Catena, v. 79, p. 288-296.

National Institute of Standards \& Technology, 2000, Reference Material 8704 Buffalo River Sediment, Department of Commerce, Gaithersburg, MD.

National Oceanic and Atmospheric Administration, 2015, Global Analysis- Annual 2015, 2015 year-to-date temperature versus previous years, NOAA’s National Centers for Environmental Information; [accessed 2016 Feb 20, graph created 2016 Jan 19]. https:// www.ncdc.noaa.gov/sotc/global/2015/13/supplemental/page-3

National Oceanic and Atmospheric Administration, 2016a, Advanced Hydrology

Prediction Services, Cleveland $(\mathrm{OH})$ : National Weather Service, (last modified 2016 Feb 17), http://water.weather.gov/

National Oceanic and Atmospheric Administration, 2016b, Annual Top 10 Records for Akron-Canton, Ohio. N.D. Cleveland (OH): National Weather Service; http://www. weather.gov/cle/Top10Annual (accessed 2016 Feb 15).

Ohio Division of Geological Survey, 2005, Glacial map of Ohio: Ohio Department of Natural Resources, Division of Geological Survey Map BG-1, generalized page-size version with text, 2 p., scale 1:2,000,000.

Ohio Division of Geological Survey, 2006, Bedrock geologic map of Ohio: Ohio Department of Natural Resources, Division of Geological Survey Map BG-1, generalized page-size version with text, 2 p., scale 1:2,000,000.

Ohio Department of Natural Resources, 2014, Division of Soil and Water Conservation, Field Sheet for the Ohio Sediment Stick: http://olms.org/wp-content/uploads/2014/03/ sediment-stick-instructions.pdf (Accessed March, 2016).

Ohio Department of Natural Resources, 2016, Ohio Dam Safety Program: https://gis. ohiodnr.gov/MapViewer/?config=ohiodams (Accessed April 2016).

Ouyang. T. Tian C., Zhu Z., Qui Y., Appel E., Fu S., 2014, Magnetic characteristics and its environmental implications for core YSJD-86GC sediments from the southern South China Sea, Chin. Sci. Bull., v. 59, no. 25, p. 3176-3187. 
Parmenter, B., and Melcher, J., 2012, Watershed and Drainage Delineation by Pour Point in ArcMap 10: http://sites.tufts.edu/gis/files/2013/11/Watershed-and-DrainageDelineation-by-Pour-Point.pdf (Accessed September 2016).

Peck J.A., Professor of Geoscience at the University of Akron, Interview with Andrea Rocchio, Personal Interview, December, 2016.

Peck J.A., Mullen A., Moore A., Rumschlag J.H., 2007, The legacy sediment record within the Monroe Falls dam pool, Cuyahoga River, Summit County, Ohio: J. Great Lakes Res., v. 33, no. 2, p. 127-141.

Pielke Sr. R.A., 2005 Dec 9, Land use and climate change, Science, v. 310, p. 1625-1626.

Poudyal N.C., Elkins D., Nibbelink N., Cordell H.K., Gyawali B., 2016, An exploratoryspatial analysis of projected hotspots of population, natural land loss, and climate change in the conterminous United States, Land Use Policy, v. 51, p. 325-334.

Rumschlag J.H., Peck J.A., 2007, Short-term sediment and morphologic response of the Middle Cuyahoga River to the removal of the Munroe Falls Dam, Summit

County, Ohio, J. Great Lakes Res., v. 33, no. 2, p. 142-153.

Seguin M. and Seguin S., 2000, Images of America, Cuyahoga Falls, Ohio: Chicago, Illinois, Arcadia Publishing, 128 p.

Schleis P., 2014, Properties that Cuyahoga Falls would buy to help out Menards also fills city's wish list for trail to valley: Akron Beacon Journal, http://www.ohio.com/news/ local/property-that-cuyahoga-falls-would-buy-to-help-out-menards-also-fills-city-swish-list-for-trail-to-valley-1.506955

Schleis P., 2015 Aug 12, Menards delaying Cuyahoga Falls store for one more year, Akron Beacon Journal, http://www.ohio.com/news/local/menards-delaying-cuyahogafalls-store-for-one-more-year-1.615651

Schleis P., 2016, Plans for Menards store in Falls get delayed again: Akron Beacon Journal, (in press).

Schleis P., 2017, Cuyahoga Falls has creative plans for raising money to fix up Mill Pond and Mud Brook greenway: Akron Beacon Journal, http://www.ohio.com/news/local/ cuyahoga-falls-has-creative-plans-for-raising-money-to-fix-up-mill-pond-and-mudbrook-greenway-1.756150\#

Shaw K. A., 2013, Assessing two centuries of anthropogenic impacts on Silver Lake, Summit County, Ohio [Master of Science thesis]: Akron, The University of Akron, 194p.

Schillereff D.N., Chiverrell R.C., Macdonald N., Hooke J.M., 2014, Flood stratigraphies in lake sediment: A review, Earth-Science Reviews., v. 135, p. 17-37.

Stapanian M.A., Schumacher W., Gara B., Viau N. 2016. Mosses in Ohio wetlands respond to indices of disturbance and vascular plant integrity. Ecological Indicators. 63: 110-120. 
"Boston” [map] In: 1936 Aer-o-plat of Summit County Ohio: Sidwell Studio, 1,200 ft to 1 in, 767p.

“Northampton” [map] In: 1936 Aer-o-plat of Summit County Ohio: Sidwell Studio, 1,200 ft to 1 in, 767p.

"Stow" [map] In: 1936 Aer-o-plat of Summit County Ohio: Sidwell Studio, 1,200 ft to 1 in, 767p.

“Boston” [map] In: 1951 Aer-o-plat of Summit County Ohio: Sidwell Studio, 1,200 ft to 1 in, 767p.

“Northampton” [map] In: 1951 Aer-o-plat of Summit County Ohio: Sidwell Studio, 1,200 ft to 1 in, 767p.

"Stow" [map] In: 1951 Aer-o-plat of Summit County Ohio: Sidwell Studio, 1,200 ft to 1 in, 767p.

"Summit county" [map] In: combination Atlas Map of Summit county Ohio.

Philadelphia: Tackabury, Mead \& Moffett Publishing, 1874.

Summit County Historical Society, 2008, Iron Bridge-Northampton: Summit Memory, http://www.summitmemory.org/cdm/singleitem/collection/building/id/367/rec/1

(Accessed March 2016).

Summit County Fiscal Office GIS Data Downloads: http://fiscaloffice.summitoh. net/index.php/documents-a-forms/viewcategory/40-gis-data-downloads (Accessed December, 2015).

Summit County Parcel Viewer, 2016: http://summitmaps.summitoh.net/ ParcelViewer/ (Accessed August, 2016)

Szabo J.P., Huth-Pyscher C.G., Kushner V.A., 2013, Lake Wisconsinan sediments parallel to axis of the buried valley of Mud Brook north of Akron, Summit County, Ohio, The Ohio Journal of Science, v. 111, no. 2-5, p. 18-27.

Szabo J.P., 2011, Pleistocene Glaciation of Ohio, in Ehlers J.Gibbard L.P., Hughes P.D., eds., Quaternary Glaciations-Extent and Chronology: A Closer Look: Elsevier, Oxford, p. 513-518.

Szabo J.P., Bradley K., Tevesz J.S., 2003, Foundations from the past: Clues to understanding Late Quaternary stratigraphy beneath Cleveland, OH, J. Great Lakes Res., v. 29, no. 4, p. 566-580.

Szabo J.P., 1986, Wisconsinan stratigraphy of the Cuyahoga Valley in the Erie Basin, northeastern Ohio, Can. J. Earth. Sci., v. 24, p. 279-290.

The Cleveland Press, 1981, Oil Spill Cleanup Map: The Cleveland Press (In Press). "Boston" [map] In: Atlas and Industrial Geography of Summit County Ohio. Akron: The Rectigraph Abstract and Title company, 1910. 
“Northampton” [map] In: Atlas and Industrial Geography of Summit County Ohio. Akron: The Rectigraph Abstract and Title company, 1910.

"Stow" [map] In: Atlas and Industrial Geography of Summit County Ohio. Akron: The Rectigraph Abstract and Title company, 1910.

"Summit county" [map] In: combination Atlas Map of Summit County Ohio, Philadelphia: Tackabury, Mead \& Moffett Publishing, 1874.

United States Census Bureau, 2015, Geography: Maps \& Data: http://www.census.gov/ geo/maps-data/ (Accessed December 2015).

United States Department of Agriculture, Natural Resources Conservation Service Ohio: Technical Resources: https://www.nrcs.usda.gov/wps/portal/nrcs/detail/oh/ technical/?cid=nrcs144p2_029586 (Accessed January 2017).

United States Environmental Protection Agency, 2014, Climate Chante Indicators in the United States, 2014 (third edition), EPA 430-R-14-004. www.epa.gov/climatechange/ indicators.

United States Geological Survey, Peninsula Quadrangle, Ohio 1905. 1:24,000. 7.5 minute series topographic.

United States Geological Survey, Peninsula Quadrangle, Ohio 1963. 1:24,000. 7.5 minute series topographic.

United States Geological Survey, Peninsula Quadrangle, Ohio 1994. 1:24,000. 7.5 minute series topographic.

United States Geological Survey, 2016a, Mean daily discharge data [1921-2016], 04206000 Cuyahoga River at Old Portage OH: http://waterdata.usgs.gov/usa/nwis/ uv?04206000 (Accessed February 2, 2016).

United States Geological Survey, 2016b, EarthExplorer: http://earthexplorer.usgs.gov/ (Accessed September, 2016).

Wiandt S., 2010, Land purchases OK'd for Howe-Main project, Cuyahoga Falls News Press, http://www.fallsnewspress.com/news\%20local/2010/04/18/land-purchases-okdfor-howemain-project

Webb-Sullivan L.D., Evans J.E., 2014, Sediment budget approach to understanding historical stages of the Ottawa River in the context of land-use change, northwestern Ohio and southeastern Michigan, USA, Anthropocene, v. 7 p. 42-56.

Wohl E., 2015, Legacy effects on sediment in river corridors, Earth-Science Reviews, v. 147, p. 30-53.

Wohl E., 2013, Wilderness is dead: Whither critical zones studies and geomorphology in the Anthropocene?, Anthropocene, v. 2, p. 4-15.

Wolman M.G., 1967, A cycle of sedimentation and erosion in urban river channels: Geogrfiska Annaler, Series A, Physical Geography, v. 49, no. 2/4, p. 385-395. 
Yuan F. Quellos J.A., Fan C., 2013, Controls of phosphorous loading and transport in the Cuyahoga River of northeastern Ohio, USA, Applied Geochemistry, v. 38, p. 59-69.

Zapinski K., 1994, Park Service deal saves Scout camps: The Plain Dealer (in press). 
APPENDICES 


\section{APPENDIX A \\ HASKELL RUN DISCHARGE AND TOTAL SUSPENDED SEDIMENT}

On March 25 and November 21, 2016, the sediment trapping efficiency of Lake Butler was estimated by measuring the inflow and outflow discharge. The inflow and outflow water discharge was measured with a Gurley Pygmy flow meter and meter stick. Total suspended sediment (TSS) concentrations were measured with the Ohio Sediment Stick (ODNR, 2014). 


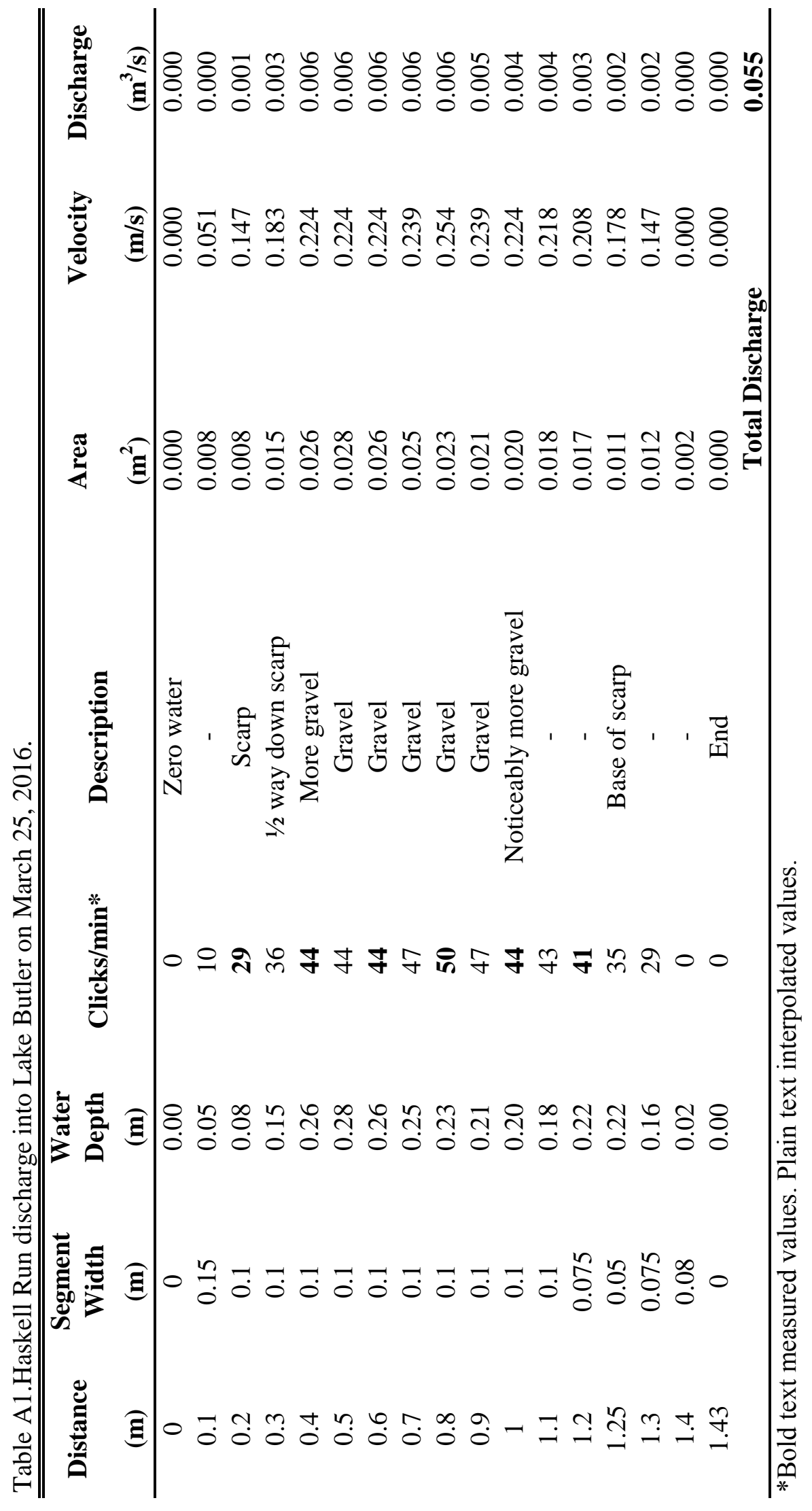




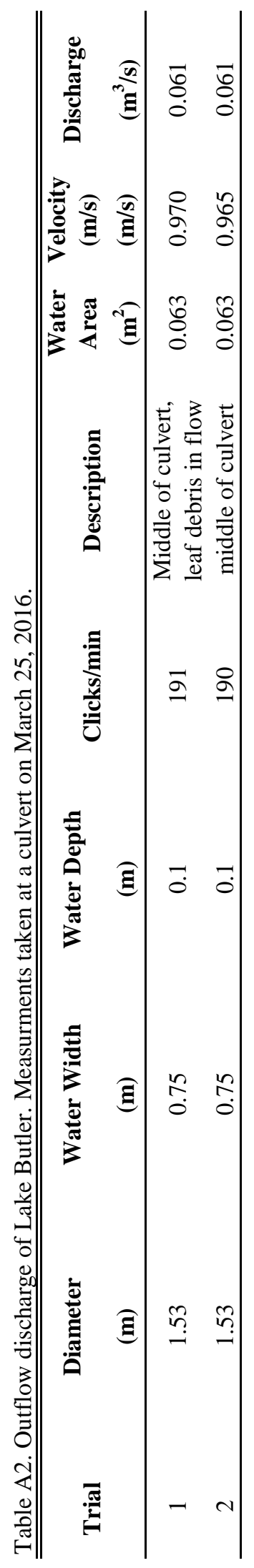




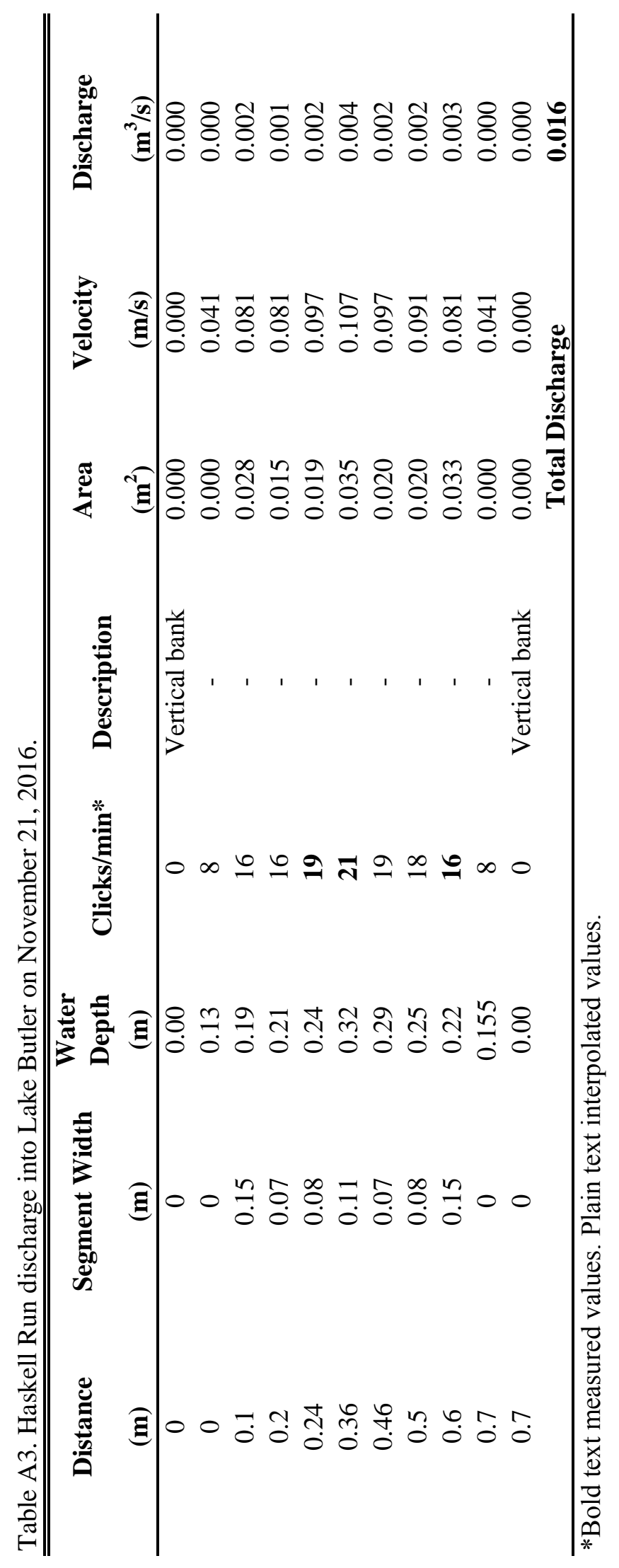




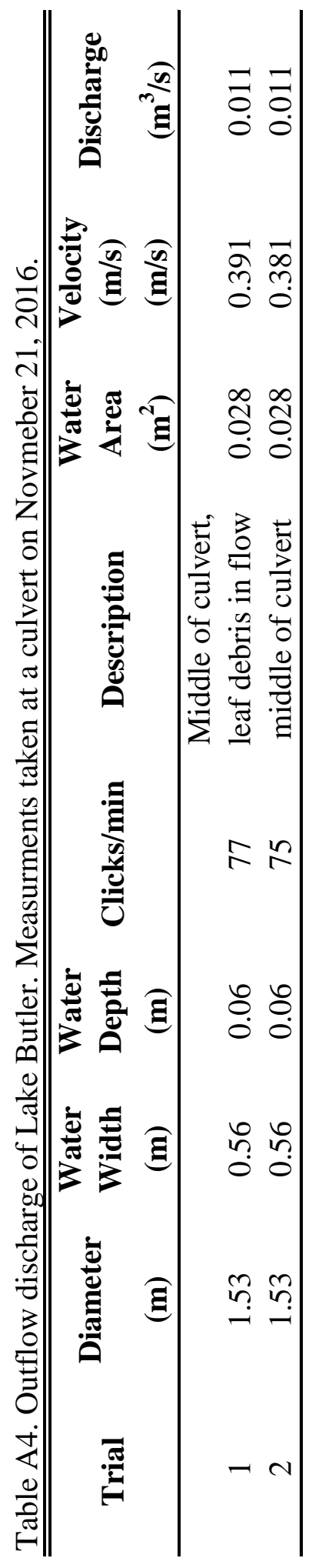


Table A5. River inflow and culvert outflow from Lake Butler. A. Measurements taken March 25, 2016. B. Measurements taken November 21, 2016.

\begin{tabular}{|c|c|c|c|c|}
\hline Site & $\begin{array}{l}\text { Ohio Sediment Stick } \\
\text { (in) } \\
\end{array}$ & $\begin{array}{l}\text { TSS } \\
(\mathrm{mg} / \mathrm{l}) \\
\end{array}$ & $\begin{array}{c}\mathrm{Qw} \\
\left(\mathrm{m}^{3} / \mathrm{s}\right)\end{array}$ & $\begin{array}{c}\text { Qs } \\
(\mathrm{g} / \mathrm{sec}) \\
\end{array}$ \\
\hline Inflow & 10.7 & 29.7 & - & - \\
\hline Inflow & 9.4 & 36 & - & - \\
\hline Inflow & 10.5 & 31 & - & - \\
\hline Inflow & 12 & 26.5 & - & - \\
\hline Inflow Average: & 10.7 & 30.8 & 0.055 & 1.69 \\
\hline Lake & 15.8 & 18.1 & - & - \\
\hline Lake & 10 & 33.7 & - & - \\
\hline Lake Average: & 12.9 & 25.9 & - & - \\
\hline Outflow & 13 & 23.8 & - & - \\
\hline Outflow & 12 & 21.6 & - & - \\
\hline Outflow & 13.8 & 19.7 & - & - \\
\hline Outflow Average: & 12.9 & 21.7 & 0.061 & 1.32 \\
\hline \multicolumn{5}{|l|}{ B. } \\
\hline Site & $\begin{array}{l}\text { Ohio Sediment Stick } \\
\text { (in) }\end{array}$ & $\begin{array}{l}\text { TSS } \\
(\mathrm{mg} / \mathrm{l})\end{array}$ & $\begin{array}{c}\mathrm{Qw} \\
\left(\mathrm{m}^{3} / \mathrm{s}\right)\end{array}$ & $\begin{array}{c}\text { Qs } \\
(\mathrm{g} / \mathrm{sec})\end{array}$ \\
\hline Inflow & 36 & $>5$ & - & - \\
\hline Inflow & 36 & $>5$ & - & - \\
\hline Inflow Average: & 36 & $>5$ & 0.016 & 0.08 \\
\hline Lake & 18.5 & 15 & - & - \\
\hline Lake & 23.8 & 11 & - & - \\
\hline Lake & 23.5 & 11 & - & - \\
\hline Lake Average: & 21.9 & 12.3 & - & - \\
\hline Outflow & 25 & 10.1 & - & - \\
\hline Outflow & 24.7 & 10.3 & - & - \\
\hline Outflow & 27 & 9.1 & - & - \\
\hline Outflow Average: & 25.6 & 9.8 & 0.011 & 0.11 \\
\hline
\end{tabular}




\section{APPENDIX B \\ SEDIMENT CORE LOSS-ON-IGNITION AND WHOLE CORE SUSCEPTIBILITY (K) FOR LAKE BUTLER, LAKE LITCHFIELD, AND OLD MILL POND}

Dry bulk density, wet bulk density, organic matter content, water content, and wholecore magnetic susceptibility $(\kappa)$ measurements were conducted on all cores from Lake Butler, Lake Litchfield, and Old Mill Pond. 
Table B1. LOI data for Lake Butler core 1.

\begin{tabular}{|c|c|c|c|c|c|c|c|}
\hline Core-Drive & $\begin{array}{l}\text { Depth in } \\
\text { Drive } \\
(\mathrm{cm})\end{array}$ & $\begin{array}{l}\text { Depth in } \\
\text { Core } \\
\text { (cm) }\end{array}$ & $\begin{array}{l}\text { Corrected } \\
\text { Depth in } \\
\text { Core } \\
(\mathrm{cm})\end{array}$ & $\begin{array}{c}\text { Organic } \\
\text { Matter } \\
(\%)\end{array}$ & $\begin{array}{c}\text { Wet bulk } \\
\text { Density } \\
\left(\mathrm{g} / \mathrm{cm}^{3}\right)\end{array}$ & $\begin{array}{c}\text { Dry Bulk } \\
\text { Density } \\
\left(\mathrm{g} / \mathrm{cm}^{3}\right)\end{array}$ & $\begin{array}{c}\text { Water } \\
\text { Content } \\
\text { (\%) }\end{array}$ \\
\hline \multirow[t]{40}{*}{ LB-16-C1-D1 } & 0.5 & 0.5 & 0.725 & 7.2 & 1.491 & 0.949 & 36.4 \\
\hline & 1.5 & 1.5 & 2.175 & 7.2 & 1.495 & 0.946 & 36.7 \\
\hline & 2.5 & 2.5 & 3.625 & 6.2 & 1.625 & 1.046 & 35.6 \\
\hline & 3.5 & 3.5 & 5.075 & 6.1 & 1.546 & 1.001 & 35.3 \\
\hline & 4.5 & 4.5 & 6.525 & 6.9 & 1.467 & 0.865 & 41.0 \\
\hline & 5.5 & 5.5 & 7.975 & 6.8 & 1.488 & 0.876 & 41.1 \\
\hline & 6.5 & 6.5 & 9.425 & 6.8 & 1.422 & 0.853 & 40.0 \\
\hline & 7.5 & 7.5 & 10.875 & 6.8 & 1.426 & 0.818 & 42.6 \\
\hline & 8.5 & 8.5 & 12.325 & 7.4 & 1.412 & 0.810 & 42.6 \\
\hline & 9.5 & 9.5 & 13.775 & 6.5 & 1.510 & 0.928 & 38.5 \\
\hline & 10.5 & 10.5 & 15.225 & 7.8 & 1.337 & 0.768 & 42.6 \\
\hline & 11.5 & 11.5 & 16.675 & 6.4 & 1.403 & 0.877 & 37.5 \\
\hline & 12.5 & 12.5 & 18.125 & 6.9 & 1.395 & 0.857 & 38.6 \\
\hline & 13.5 & 13.5 & 19.575 & 6.3 & 1.508 & 0.956 & 36.6 \\
\hline & 14.5 & 14.5 & 21.025 & 7.0 & 1.449 & 0.859 & 40.7 \\
\hline & 15.5 & 15.5 & 22.475 & 6.6 & 1.428 & 0.882 & 38.2 \\
\hline & 16.5 & 16.5 & 23.925 & 7.6 & 1.457 & 0.860 & 41.0 \\
\hline & 17.5 & 17.5 & 25.375 & 7.2 & 1.469 & 0.888 & 39.6 \\
\hline & 18.5 & 18.5 & 26.825 & 6.0 & 1.602 & 1.063 & 33.6 \\
\hline & 19.5 & 19.5 & 28.275 & 6.2 & 1.614 & 1.082 & 33.0 \\
\hline & 20.5 & 20.5 & 29.725 & 6.2 & 1.578 & 1.029 & 34.8 \\
\hline & 21.5 & 21.5 & 31.175 & 6.4 & 1.563 & 1.000 & 36.0 \\
\hline & 22.5 & 22.5 & 32.625 & 5.4 & 1.569 & 1.073 & 31.6 \\
\hline & 23.5 & 23.5 & 34.075 & 6.8 & 1.473 & 0.923 & 37.3 \\
\hline & 24.5 & 24.5 & 35.525 & 5.6 & 1.674 & 1.126 & 32.7 \\
\hline & 25.5 & 25.5 & 36.975 & 6.1 & 1.691 & 1.134 & 32.9 \\
\hline & 26.5 & 26.5 & 38.425 & 5.4 & 1.530 & 1.007 & 34.2 \\
\hline & 27.5 & 27.5 & 39.875 & 8.3 & 1.398 & 0.797 & 43.0 \\
\hline & 28.5 & 28.5 & 41.325 & 8.3 & 1.421 & 0.863 & 39.3 \\
\hline & 29.5 & 29.5 & 42.775 & 6.0 & 1.635 & 1.078 & 34.1 \\
\hline & 30.5 & 30.5 & 44.225 & 5.7 & 1.626 & 1.080 & 33.6 \\
\hline & 31.5 & 31.5 & 45.675 & 3.4 & 1.746 & 1.248 & 28.5 \\
\hline & 32.5 & 32.5 & 47.125 & 6.2 & 1.521 & 0.954 & 37.3 \\
\hline & 33.5 & 33.5 & 48.575 & 6.3 & 1.603 & 1.024 & 36.1 \\
\hline & 34.5 & 34.5 & 50.025 & 6.3 & 1.579 & 0.983 & 37.7 \\
\hline & 35.5 & 35.5 & 51.475 & 6.6 & 1.474 & 0.875 & 40.6 \\
\hline & 36.5 & 36.5 & 52.925 & 7.1 & 1.493 & 0.877 & 41.3 \\
\hline & 37.5 & 37.5 & 54.375 & 7.6 & 1.396 & 0.807 & 42.2 \\
\hline & 38.5 & 38.5 & 55.825 & 6.7 & 1.446 & 0.780 & 46.1 \\
\hline & 39.5 & 39.5 & 57.275 & 6.3 & 1.528 & 0.885 & 42.1 \\
\hline
\end{tabular}


Table B1. (Cont) LOI data for Lake Butler core 1.

\begin{tabular}{|c|c|c|c|c|c|c|c|}
\hline Core-Drive & $\begin{array}{c}\text { Depth in } \\
\text { Drive } \\
(\mathrm{cm})\end{array}$ & $\begin{array}{l}\text { Depth in } \\
\text { Core } \\
(\mathrm{cm}) \\
\end{array}$ & $\begin{array}{c}\text { Corrected } \\
\text { Depth in } \\
\text { Core } \\
(\mathrm{cm}) \\
\end{array}$ & $\begin{array}{c}\text { Organic } \\
\text { Matter } \\
(\%) \\
\end{array}$ & $\begin{array}{c}\text { Wet bulk } \\
\text { Density } \\
\left(\mathrm{g} / \mathrm{cm}^{3}\right)\end{array}$ & $\begin{array}{c}\text { Dry Bulk } \\
\text { Density } \\
\left(\mathrm{g} / \mathrm{cm}^{3}\right) \\
\end{array}$ & $\begin{array}{c}\text { Water } \\
\text { Content } \\
(\%) \\
\end{array}$ \\
\hline \multirow[t]{11}{*}{ LB-16-C1-D1 } & 40.5 & 40.5 & 58.725 & 5.8 & 1.595 & 1.020 & 36.1 \\
\hline & 41.5 & 41.5 & 60.175 & 5.2 & 1.627 & 1.098 & 32.5 \\
\hline & 42.5 & 42.5 & 61.625 & 5.4 & 1.643 & 1.109 & 32.5 \\
\hline & 46.5 & 46.5 & 67.425 & 3.7 & 1.572 & 1.133 & 27.9 \\
\hline & 47.5 & 47.5 & 68.875 & 7.6 & 1.335 & 0.853 & 36.1 \\
\hline & 48.5 & 48.5 & 70.325 & 5.4 & 1.495 & 1.014 & 32.2 \\
\hline & 49.5 & 49.5 & 71.775 & 8.1 & 1.407 & 0.838 & 40.4 \\
\hline & 50.5 & 50.5 & 73.225 & 6.1 & 1.593 & 1.023 & 35.8 \\
\hline & 51.5 & 51.5 & 74.675 & 5.8 & 1.490 & 0.978 & 34.4 \\
\hline & 52.5 & 52.5 & 76.125 & 6.4 & 1.374 & 0.829 & 39.7 \\
\hline & 53.5 & 53.5 & 77.575 & 5.4 & 1.551 & 1.029 & 33.7 \\
\hline \multirow[t]{26}{*}{ LB-16-C1-D2 } & 54.5 & 54.5 & 79.000 & 1.6 & 1.540 & 1.230 & 20.1 \\
\hline & 0.5 & Hole fill & - & 3.3 & 1.606 & 1.121 & 30.2 \\
\hline & 1.5 & Hole fill & - & 4.8 & 1.581 & 1.039 & 34.3 \\
\hline & 3.5 & 80.0 & 80.000 & 0.7 & 1.734 & 1.427 & 17.7 \\
\hline & 4.5 & 81.0 & 81.000 & 0.7 & 1.720 & 1.408 & 18.1 \\
\hline & 5.5 & 82.0 & 82.000 & 2.2 & 1.669 & 1.386 & 17.0 \\
\hline & 6.5 & 83.0 & 83.000 & 0.7 & 1.772 & 1.447 & 18.3 \\
\hline & 7.5 & 84.0 & 84.000 & 1.6 & 1.645 & 1.318 & 19.9 \\
\hline & 8.5 & 85.0 & 85.000 & 8.2 & 1.400 & 0.900 & 35.7 \\
\hline & 9.5 & 86.0 & 86.000 & 6.5 & 1.619 & 1.031 & 36.3 \\
\hline & 10.5 & 87.0 & 87.000 & 9.3 & 1.370 & 0.806 & 41.2 \\
\hline & 15.5 & 92.0 & 92.000 & 7.8 & 1.408 & 0.862 & 38.8 \\
\hline & 16.5 & 93.0 & 93.000 & 8.0 & 1.391 & 0.845 & 39.3 \\
\hline & 17.5 & 94.0 & 94.000 & 19.7 & 0.973 & 0.396 & 59.3 \\
\hline & 18.5 & 95.0 & 95.000 & 16.2 & 1.022 & 0.493 & 51.8 \\
\hline & 19.5 & 96.0 & 96.000 & 8.6 & 1.392 & 0.838 & 39.8 \\
\hline & 20.5 & 97.0 & 97.000 & 7.2 & 1.565 & 0.984 & 37.1 \\
\hline & 21.5 & 98.0 & 98.000 & 4.5 & 1.312 & 0.928 & 29.3 \\
\hline & 22.5 & 99.0 & 99.000 & 14.2 & 1.326 & 0.713 & 46.2 \\
\hline & 23.5 & 100.0 & 100.000 & 12.7 & 1.375 & 0.740 & 46.2 \\
\hline & 24.5 & 101.0 & 101.000 & 8.5 & 1.478 & 0.860 & 41.8 \\
\hline & 25.5 & 102.0 & 102.000 & 9.1 & 1.533 & 0.872 & 43.1 \\
\hline & 26.5 & 103.0 & 103.000 & 8.7 & 1.494 & 0.842 & 43.6 \\
\hline & 27.5 & 104.0 & 104.000 & 9.6 & 1.366 & 0.729 & 46.6 \\
\hline & 28.5 & 105.0 & 105.000 & 8.8 & 1.419 & 0.782 & 44.9 \\
\hline & 29.5 & 106.0 & 106.000 & 7.9 & 1.424 & 0.857 & 39.8 \\
\hline
\end{tabular}


Table B1. (Cont) LOI data for Lake Butler core 1.

\begin{tabular}{cccccccc}
\hline \hline \multirow{2}{*}{ Core-Drive } & $\begin{array}{c}\text { Depth in } \\
\text { Drive }\end{array}$ & $\begin{array}{c}\text { Depth in } \\
\text { Core }\end{array}$ & $\begin{array}{c}\text { Corrected } \\
\text { Depth in } \\
\text { Core }\end{array}$ & $\begin{array}{c}\text { Organic } \\
\text { Matter }\end{array}$ & $\begin{array}{c}\text { Wet bulk } \\
\text { Density }\end{array}$ & $\begin{array}{c}\text { Dry Bulk } \\
\text { Density }\end{array}$ & $\begin{array}{c}\text { Water } \\
\text { Content }\end{array}$ \\
& $(\mathrm{cm})$ & $(\mathrm{cm})$ & $(\mathrm{cm})$ & $(\%)$ & $\left(\mathrm{g} / \mathrm{cm}^{3}\right)$ & $\left(\mathrm{g} / \mathrm{cm}^{3}\right)$ & $(\%)$ \\
\hline LB-16-C1-D2 & 30.5 & 107.0 & 107.000 & 3.0 & 1.674 & 1.242 & 25.8 \\
& 31.5 & 108.0 & 108.000 & 9.7 & 1.364 & 0.829 & 39.2 \\
& 32.5 & 109.0 & 109.000 & 10.8 & 1.258 & 0.697 & 44.6 \\
& 33.5 & 110.0 & 110.000 & 6.5 & 1.577 & 1.022 & 35.2 \\
& 34.5 & 111.0 & 111.000 & 6.8 & 1.480 & 0.944 & 36.2 \\
& 35.5 & 112.0 & 112.000 & 6.1 & 1.682 & 1.096 & 34.8 \\
& 36.5 & 113.0 & 113.000 & 9.0 & 1.536 & 0.910 & 40.8 \\
& 37.5 & 114.0 & 114.000 & 6.8 & 1.614 & 1.022 & 36.7 \\
& 38.5 & 115.0 & 115.000 & 9.1 & 1.582 & 0.940 & 40.6 \\
& 39.5 & 116.0 & 116.000 & 7.6 & 1.512 & 0.921 & 39.1 \\
40.5 & 117.0 & 117.000 & 7.5 & 1.473 & 0.897 & 39.1 \\
& 41.5 & 118.0 & 118.000 & 7.6 & 1.508 & 0.909 & 39.7 \\
& 42.5 & 119.0 & 119.000 & 9.4 & 1.461 & 0.811 & 44.5 \\
43.5 & 120.0 & 120.000 & 8.4 & 1.367 & 0.761 & 44.3 \\
& 44.5 & 121.0 & 121.000 & 6.8 & 1.539 & 0.948 & 38.4 \\
45.5 & 122.0 & 122.000 & 7.1 & 1.561 & 0.968 & 38.0 \\
46.5 & 123.0 & 123.000 & 6.5 & 1.621 & 1.038 & 36.0 \\
47.5 & 124.0 & 124.000 & 6.7 & 1.609 & 1.043 & 35.2 \\
48.5 & 125.0 & 125.000 & 6.7 & 1.492 & 0.946 & 36.6 \\
49.5 & 126.0 & 126.000 & 6.7 & 1.627 & 1.014 & 37.7 \\
\hline
\end{tabular}


Table B2. Whole-core susceptibility ( $\kappa)$ for Lake Butler core 1.

\begin{tabular}{|c|c|c|c|c|c|}
\hline \multirow{2}{*}{ Core-Drive } & $\begin{array}{l}\text { Depth in } \\
\text { Drive }\end{array}$ & $\begin{array}{l}\text { Depth in } \\
\text { Core }\end{array}$ & $\begin{array}{c}\text { Corrected } \\
\text { Depth in Core }\end{array}$ & $\kappa$ & Edited $\kappa$ \\
\hline & $(\mathrm{cm})$ & $(\mathrm{cm})$ & $(\mathrm{cm})$ & $\begin{array}{c}\left(10^{-5} \text { Relative }\right. \\
\text { SI Units })\end{array}$ & $\begin{array}{c}\left(10^{-5} \text { Relative SI }\right. \\
\text { Units) }\end{array}$ \\
\hline \multirow[t]{19}{*}{ LB-16-C1-D1 } & 0.0 & 0.0 & - & 9.3 & - \\
\hline & 3.0 & 3.0 & 4.4 & 11.4 & 11.4 \\
\hline & 6.0 & 6.0 & 8.7 & 10.4 & 10.4 \\
\hline & 9.0 & 9.0 & 13.1 & 10.5 & 10.5 \\
\hline & 12.0 & 12.0 & 17.4 & 11.0 & 11.0 \\
\hline & 15.0 & 15.0 & 21.8 & 10.7 & 10.7 \\
\hline & 18.0 & 18.0 & 26.1 & 11.5 & 11.5 \\
\hline & 21.0 & 21.0 & 30.5 & 12.5 & 12.5 \\
\hline & 24.0 & 24.0 & 34.8 & 12.9 & 12.9 \\
\hline & 27.0 & 27.0 & 39.2 & 13.1 & 13.1 \\
\hline & 30.0 & 30.0 & 43.5 & 15.5 & 15.5 \\
\hline & 33.0 & 33.0 & 47.9 & 15.9 & 15.9 \\
\hline & 36.0 & 36.0 & 52.2 & 13.2 & 13.2 \\
\hline & 39.0 & 39.0 & 56.6 & 13.1 & 13.1 \\
\hline & 42.0 & 42.0 & 60.9 & 14.3 & 14.3 \\
\hline & 45.0 & 45.0 & 65.3 & 10.9 & 10.9 \\
\hline & 48.0 & 48.0 & 69.6 & 13.7 & 13.7 \\
\hline & 51.0 & 51.0 & 74.0 & 14.7 & 14.7 \\
\hline & 54.0 & 54.0 & - & 11.4 & - \\
\hline \multirow[t]{18}{*}{ LB-16-C1-D2 } & 0.0 & 76.5 & - & 8.0 & - \\
\hline & 3.0 & 79.5 & - & 11.6 & - \\
\hline & 6.0 & 82.5 & 82.5 & 12.9 & 12.9 \\
\hline & 9.0 & 85.5 & 85.5 & 14.3 & 14.3 \\
\hline & 12.0 & 88.5 & 88.5 & 13.9 & 13.9 \\
\hline & 15.0 & 91.5 & 91.5 & 14.5 & 14.5 \\
\hline & 18.0 & 94.5 & 94.5 & 15.7 & 15.7 \\
\hline & 21.0 & 97.5 & 97.5 & 16.4 & 16.4 \\
\hline & 24.0 & 100.5 & 100.5 & 13.2 & 13.2 \\
\hline & 27.0 & 103.5 & 103.5 & 12.9 & 12.9 \\
\hline & 30.0 & 106.5 & 106.5 & 13.3 & 13.3 \\
\hline & 33.0 & 109.5 & 109.5 & 15.2 & 15.2 \\
\hline & 36.0 & 112.5 & 112.5 & 16.3 & 16.3 \\
\hline & 39.0 & 115.5 & 115.5 & 14.7 & 14.7 \\
\hline & 42.0 & 118.5 & 118.5 & 14.1 & 14.1 \\
\hline & 45.0 & 121.5 & 121.5 & 14.8 & 14.8 \\
\hline & 48.0 & 124.5 & 124.5 & 14.3 & 14.3 \\
\hline & 51.0 & 127.5 & - & 9.0 & - \\
\hline
\end{tabular}


Table B3. LOI data for Lake Butler core 4.

\begin{tabular}{|c|c|c|c|c|c|c|}
\hline Core-Drive & $\begin{array}{c}\text { Depth in } \\
\text { Drive } \\
(\mathrm{cm})\end{array}$ & $\begin{array}{l}\text { Depth in } \\
\text { Core } \\
(\mathrm{cm})\end{array}$ & $\begin{array}{c}\text { Organic } \\
\text { Matter } \\
(\%)\end{array}$ & $\begin{array}{c}\text { Wet bulk } \\
\text { Density } \\
\left(\mathrm{g} / \mathrm{cm}^{3}\right)\end{array}$ & $\begin{array}{c}\text { Dry Bulk } \\
\text { Density } \\
\left(\mathrm{g} / \mathrm{cm}^{3}\right)\end{array}$ & $\begin{array}{c}\text { Water } \\
\text { Content } \\
(\%)\end{array}$ \\
\hline \multirow[t]{40}{*}{ LB-16-C4-D1 } & 0.5 & 0.5 & 10.1 & 1.332 & 0.805 & 39.6 \\
\hline & 1.5 & 1.5 & 6.8 & 1.443 & 0.880 & 39.0 \\
\hline & 2.5 & 2.5 & 6.8 & 1.387 & 0.828 & 40.3 \\
\hline & 3.5 & 3.5 & 6.3 & 1.582 & 1.035 & 34.6 \\
\hline & 4.5 & 4.5 & 5.7 & 1.561 & 1.000 & 35.9 \\
\hline & 5.5 & 5.5 & 6.0 & 1.588 & 1.004 & 36.8 \\
\hline & 6.5 & 6.5 & 5.4 & 1.608 & 1.022 & 36.4 \\
\hline & 7.5 & 7.5 & 5.2 & 1.675 & 1.098 & 34.4 \\
\hline & 8.5 & 8.5 & 5.8 & 1.584 & 1.005 & 36.6 \\
\hline & 9.5 & 9.5 & 7.2 & 1.415 & 0.789 & 44.2 \\
\hline & 10.5 & 10.5 & 6.4 & 1.521 & 0.888 & 41.6 \\
\hline & 11.5 & 11.5 & 7.4 & 1.469 & 0.839 & 42.9 \\
\hline & 12.5 & 12.5 & 7.3 & 1.366 & 0.688 & 49.6 \\
\hline & 13.5 & 13.5 & 7.1 & 1.433 & 0.785 & 45.2 \\
\hline & 14.5 & 14.5 & 7.7 & 1.315 & 0.716 & 45.6 \\
\hline & 15.5 & 15.5 & 5.5 & 1.589 & 0.996 & 37.3 \\
\hline & 16.5 & 16.5 & 5.1 & 1.643 & 1.086 & 33.9 \\
\hline & 17.5 & 17.5 & 5.5 & 1.549 & 0.963 & 37.8 \\
\hline & 18.5 & 18.5 & 5.9 & 1.407 & 0.841 & 40.2 \\
\hline & 19.5 & 19.5 & 6.3 & 1.510 & 0.890 & 41.1 \\
\hline & 20.5 & 20.5 & 5.1 & 1.520 & 0.948 & 37.6 \\
\hline & 21.5 & 21.5 & 5.5 & 1.591 & 1.024 & 35.6 \\
\hline & 22.5 & 22.5 & 5.7 & 1.568 & 0.987 & 37.1 \\
\hline & 23.5 & 23.5 & 6.1 & 1.524 & 0.969 & 36.4 \\
\hline & 24.5 & 24.5 & 7.3 & 1.461 & 0.810 & 44.6 \\
\hline & 25.5 & 25.5 & 6.4 & 1.447 & 0.858 & 40.7 \\
\hline & 26.5 & 26.5 & 6.2 & 1.577 & 1.015 & 35.6 \\
\hline & 27.5 & 27.5 & 5.9 & 1.590 & 1.024 & 35.6 \\
\hline & 28.5 & 28.5 & 7.3 & 1.439 & 0.830 & 42.3 \\
\hline & 29.5 & 29.5 & 6.3 & 1.397 & 0.854 & 38.9 \\
\hline & 30.5 & 30.5 & 6.1 & 1.585 & 0.978 & 38.3 \\
\hline & 31.5 & 31.5 & 7.1 & 1.567 & 0.934 & 40.4 \\
\hline & 32.5 & 32.5 & 7.0 & 1.472 & 0.884 & 39.9 \\
\hline & 33.5 & 33.5 & 6.9 & 1.580 & 0.969 & 38.7 \\
\hline & 34.5 & 34.5 & 4.4 & 1.801 & 1.301 & 27.8 \\
\hline & 35.5 & 35.5 & 3.2 & 1.721 & 1.327 & 22.9 \\
\hline & 37.5 & 37.5 & 6.8 & 1.527 & 0.957 & 37.3 \\
\hline & 38.5 & 38.5 & 6.5 & 1.573 & 0.970 & 38.3 \\
\hline & 39.5 & 39.5 & 6.9 & 1.545 & 0.900 & 41.7 \\
\hline & 40.5 & 40.5 & 6.7 & 1.528 & 0.894 & 41.5 \\
\hline
\end{tabular}


Table B3. (Cont) LOI data for Lake Butler core 4.

\begin{tabular}{|c|c|c|c|c|c|c|}
\hline Core-Drive & $\begin{array}{c}\text { Depth in } \\
\text { Drive } \\
(\mathrm{cm})\end{array}$ & $\begin{array}{l}\text { Depth in } \\
\text { Core } \\
(\mathrm{cm}) \\
\end{array}$ & $\begin{array}{c}\text { Organic } \\
\text { Matter } \\
(\%)\end{array}$ & $\begin{array}{c}\text { Wet bulk } \\
\text { Density } \\
\left(\mathrm{g} / \mathrm{cm}^{3}\right) \\
\end{array}$ & $\begin{array}{c}\text { Dry Bulk } \\
\text { Density } \\
\left(\mathrm{g} / \mathrm{cm}^{3}\right) \\
\end{array}$ & $\begin{array}{c}\text { Water } \\
\text { Content } \\
(\%) \\
\end{array}$ \\
\hline \multirow[t]{39}{*}{ LB-16-C4-D1 } & 41.5 & 41.5 & 6.9 & 1.513 & 0.886 & 41.4 \\
\hline & 42.5 & 42.5 & 6.7 & 1.548 & 0.936 & 39.5 \\
\hline & 43.5 & 43.5 & 6.5 & 1.53 & 0.963 & 37.1 \\
\hline & 44.5 & 44.5 & 6.3 & 1.529 & 0.952 & 37.7 \\
\hline & 46.5 & 46.5 & 6.2 & 1.605 & 1.033 & 35.6 \\
\hline & 47.5 & 47.5 & 6.0 & 1.605 & 1.011 & 37.0 \\
\hline & 48.5 & 48.5 & 7.3 & 1.472 & 0.848 & 42.4 \\
\hline & 49.5 & 49.5 & 6.9 & 1.511 & 0.860 & 43.1 \\
\hline & 50.5 & 50.5 & 6.3 & 1.571 & 0.943 & 40.0 \\
\hline & 51.5 & 51.5 & 6.3 & 1.507 & 0.885 & 41.3 \\
\hline & 52.5 & 52.5 & 6.4 & 1.519 & 0.906 & 40.4 \\
\hline & 53.5 & 53.5 & 7.1 & 1.5 & 0.886 & 40.9 \\
\hline & 54.5 & 54.5 & 5.9 & 1.569 & 0.936 & 40.3 \\
\hline & 55.5 & 55.5 & 5.4 & 1.677 & 1.106 & 34.0 \\
\hline & 56.5 & 56.5 & 5.2 & 1.674 & 1.124 & 32.9 \\
\hline & 57.5 & 57.5 & 5.2 & 1.77 & 1.091 & 38.4 \\
\hline & 58.5 & 58.5 & 5.4 & 1.664 & 1.067 & 35.9 \\
\hline & 59.5 & 59.5 & 6.2 & 1.661 & 1.031 & 37.9 \\
\hline & 60.5 & 60.5 & 6.2 & 1.599 & 0.999 & 37.5 \\
\hline & 61.5 & 61.5 & 7.5 & 1.449 & 0.843 & 41.8 \\
\hline & 63.0 & 63.0 & 7.6 & 1.388 & 0.824 & 40.6 \\
\hline & 64.5 & 64.5 & 8.5 & 1.396 & 0.696 & 50.1 \\
\hline & 65.5 & 65.5 & 6.6 & 1.508 & 0.861 & 42.9 \\
\hline & 66.5 & 66.5 & 7.2 & 1.545 & 0.899 & 41.8 \\
\hline & 67.5 & 67.5 & 6.7 & 1.562 & 0.935 & 40.1 \\
\hline & 68.5 & 68.5 & 8.2 & 1.234 & 0.612 & 50.4 \\
\hline & 69.5 & 69.5 & 9.0 & 1.367 & 0.655 & 52.1 \\
\hline & 70.5 & 70.5 & 7.2 & 1.482 & 0.793 & 46.5 \\
\hline & 71.5 & 71.5 & 8.1 & 1.44 & 0.801 & 44.4 \\
\hline & 72.5 & 72.5 & 7.1 & 1.496 & 0.848 & 43.3 \\
\hline & 73.5 & 73.5 & 6.9 & 1.516 & 0.945 & 37.7 \\
\hline & 74.5 & 74.5 & 6.1 & 1.619 & 1.058 & 34.7 \\
\hline & 76.5 & 76.5 & 7.9 & 1.323 & 0.796 & 39.8 \\
\hline & 78.5 & 78.5 & 1.3 & 1.762 & 1.410 & 20.0 \\
\hline & 79.5 & 79.5 & 6.2 & 1.646 & 1.079 & 34.4 \\
\hline & 80.5 & 80.5 & 10.7 & 1.334 & 0.721 & 46.0 \\
\hline & 82.5 & 82.5 & 6.0 & 1.627 & 1.037 & 36.3 \\
\hline & 83.5 & 83.5 & 6.9 & 1.545 & 0.956 & 38.1 \\
\hline & 84.5 & 84.5 & 5.6 & 1.619 & 1.062 & 34.4 \\
\hline
\end{tabular}


Table B3. (Cont) LOI data for Lake Butler core 4.

\begin{tabular}{|c|c|c|c|c|c|c|}
\hline Core-Drive & $\begin{array}{l}\text { Depth in } \\
\text { Drive } \\
(\mathrm{cm})\end{array}$ & $\begin{array}{l}\text { Depth in } \\
\text { Core } \\
(\mathrm{cm})\end{array}$ & $\begin{array}{c}\text { Organic } \\
\text { Matter } \\
(\%)\end{array}$ & $\begin{array}{c}\text { Wet bulk } \\
\text { Density } \\
\left(\mathrm{g} / \mathrm{cm}^{3}\right)\end{array}$ & $\begin{array}{c}\text { Dry Bulk } \\
\text { Density } \\
\left(\mathrm{g} / \mathrm{cm}^{3}\right)\end{array}$ & $\begin{array}{c}\text { Water } \\
\text { Content } \\
(\%)\end{array}$ \\
\hline \multirow[t]{8}{*}{ LB-16-C4-D1 } & 85.5 & 85.5 & 5.8 & 1.637 & 1.078 & 34.1 \\
\hline & 86.5 & 86.5 & 5.7 & 1.675 & 1.129 & 32.6 \\
\hline & 87.5 & 87.5 & 5.6 & 1.693 & 1.133 & 33.1 \\
\hline & 88.5 & 88.5 & 7.0 & 1.515 & 0.870 & 42.6 \\
\hline & 89.5 & 89.5 & 5.0 & 1.711 & 1.151 & 32.7 \\
\hline & 90.5 & 90.5 & 7.2 & 1.591 & 0.986 & 38.0 \\
\hline & 91.5 & 91.5 & 6.6 & 1.631 & 1.017 & 37.6 \\
\hline & 92.5 & 92.5 & 4.9 & 1.644 & 1.158 & 29.6 \\
\hline \multirow[t]{31}{*}{ LB-16-C4-D2 } & 0.5 & 100.5 & 7.1 & 1.549 & 0.935 & 39.6 \\
\hline & 1.5 & 101.5 & 6.0 & 1.623 & 1.011 & 37.7 \\
\hline & 2.5 & 102.5 & 5.8 & 1.630 & 1.078 & 33.9 \\
\hline & 3.5 & 103.5 & 5.1 & 1.749 & 1.194 & 31.7 \\
\hline & 4.5 & 104.5 & 5.9 & 1.644 & 1.069 & 35.0 \\
\hline & 5.5 & 105.5 & 8.9 & 1.466 & 0.879 & 40.0 \\
\hline & 6.5 & 106.5 & 8.3 & 1.502 & 0.917 & 38.9 \\
\hline & 7.5 & 107.5 & 8.6 & 1.484 & 0.912 & 38.5 \\
\hline & 13.5 & 113.5 & 22.5 & 1.137 & 0.516 & 54.6 \\
\hline & 14.5 & 114.5 & 7.3 & 1.621 & 1.031 & 36.4 \\
\hline & 15.5 & 115.5 & 8.1 & 1.553 & 0.922 & 40.6 \\
\hline & 16.5 & 116.5 & 9.6 & 1.474 & 0.847 & 42.5 \\
\hline & 17.5 & 117.5 & 9.1 & 1.501 & 0.869 & 42.1 \\
\hline & 18.5 & 118.5 & 7.7 & 1.556 & 0.933 & 40.0 \\
\hline & 19.5 & 119.5 & 8.0 & 1.519 & 0.877 & 42.3 \\
\hline & 20.5 & 120.5 & 9.0 & 1.462 & 0.807 & 44.8 \\
\hline & 21.5 & 121.5 & 7.3 & 1.554 & 0.936 & 39.8 \\
\hline & 22.5 & 122.5 & 6.9 & 1.612 & 0.990 & 38.6 \\
\hline & 23.5 & 123.5 & 6.9 & 1.465 & 0.858 & 41.4 \\
\hline & 24.5 & 124.5 & 6.8 & 1.456 & 0.863 & 40.7 \\
\hline & 25.5 & 125.5 & 6.2 & 1.568 & 1.021 & 34.9 \\
\hline & 26.5 & 126.5 & 6.9 & 1.593 & 1.004 & 37.0 \\
\hline & 27.5 & 127.5 & 6.5 & 1.524 & 0.966 & 36.6 \\
\hline & 28.5 & 128.5 & 7.1 & 1.555 & 0.969 & 37.7 \\
\hline & 29.5 & 129.5 & 6.9 & 1.576 & 0.992 & 37.1 \\
\hline & 30.5 & 130.5 & 7.2 & 1.590 & 0.990 & 37.7 \\
\hline & 31.5 & 131.5 & 7.2 & 1.550 & 0.927 & 40.2 \\
\hline & 32.5 & 132.5 & 6.3 & 1.562 & 0.984 & 37.0 \\
\hline & 33.5 & 133.5 & 6.0 & 1.658 & 1.073 & 35.3 \\
\hline & 34.5 & 134.5 & 6.2 & 1.624 & 1.049 & 35.4 \\
\hline & 35.5 & 135.5 & 6.5 & 1.577 & 0.999 & 36.7 \\
\hline
\end{tabular}


Table B3. (Cont) LOI data for Lake Butler core 4.

\begin{tabular}{|c|c|c|c|c|c|c|}
\hline Core-Drive & $\begin{array}{c}\text { Depth in } \\
\text { Drive } \\
(\mathrm{cm})\end{array}$ & $\begin{array}{c}\text { Depth in } \\
\text { Core } \\
\text { (cm) }\end{array}$ & $\begin{array}{c}\text { Organic } \\
\text { Matter } \\
(\%)\end{array}$ & $\begin{array}{c}\text { Wet bulk } \\
\text { Density } \\
\left(\mathrm{g} / \mathrm{cm}^{3}\right)\end{array}$ & $\begin{array}{c}\text { Dry Bulk } \\
\text { Density } \\
\left(\mathrm{g} / \mathrm{cm}^{3}\right)\end{array}$ & $\begin{array}{c}\text { Water } \\
\text { Content } \\
\text { (\%) }\end{array}$ \\
\hline \multirow[t]{39}{*}{ LB-16-C4-D2 } & 36.5 & 136.5 & 6.3 & 1.516 & 0.934 & 38.4 \\
\hline & 37.5 & 137.5 & 6.6 & 1.582 & 0.985 & 37.7 \\
\hline & 38.5 & 138.5 & 6.0 & 1.621 & 1.027 & 36.6 \\
\hline & 39.5 & 139.5 & 6.2 & 1.542 & 0.966 & 37.4 \\
\hline & 40.5 & 140.5 & 5.9 & 1.631 & 1.041 & 36.2 \\
\hline & 42.0 & 142.0 & 8.8 & 1.435 & 0.752 & 47.6 \\
\hline & 43.5 & 143.5 & 6.1 & 1.588 & 0.983 & 38.1 \\
\hline & 44.5 & 144.5 & 5.7 & 1.355 & 0.945 & 30.3 \\
\hline & 45.5 & 145.5 & 5.5 & 1.582 & 0.949 & 40.0 \\
\hline & 46.5 & 146.5 & 6.0 & 1.585 & 0.965 & 39.1 \\
\hline & 47.5 & 147.5 & 6.6 & 1.537 & 0.939 & 38.9 \\
\hline & 48.5 & 148.5 & 5.7 & 1.638 & 1.061 & 35.2 \\
\hline & 49.5 & 149.5 & 5.5 & 1.676 & 1.095 & 34.7 \\
\hline & 50.5 & 150.5 & 7.4 & 1.468 & 0.857 & 41.6 \\
\hline & 51.5 & 151.5 & 5.3 & 1.658 & 1.067 & 35.6 \\
\hline & 52.5 & 152.5 & 5.8 & 1.517 & 0.903 & 40.5 \\
\hline & 53.5 & 153.5 & 4.9 & 1.636 & 1.081 & 33.9 \\
\hline & 54.5 & 154.5 & 5.9 & 1.615 & 1.017 & 37.0 \\
\hline & 55.5 & 155.5 & 6.5 & 1.572 & 0.961 & 38.9 \\
\hline & 56.5 & 156.5 & 5.8 & 1.522 & 0.931 & 38.8 \\
\hline & 57.5 & 157.5 & 5.8 & 1.542 & 0.929 & 39.8 \\
\hline & 58.5 & 158.5 & 5.6 & 1.606 & 1.009 & 37.2 \\
\hline & 59.5 & 159.5 & 6.3 & 1.547 & 0.959 & 38.0 \\
\hline & 60.5 & 160.5 & 5.5 & 1.639 & 1.061 & 35.3 \\
\hline & 61.5 & 161.5 & 6.4 & 1.480 & 0.892 & 39.7 \\
\hline & 62.5 & 162.5 & 5.3 & 1.593 & 0.988 & 38.0 \\
\hline & 63.5 & 163.5 & 4.8 & 1.634 & 1.075 & 34.2 \\
\hline & 64.5 & 164.5 & 5.3 & 1.673 & 1.091 & 34.8 \\
\hline & 65.5 & 165.5 & 5.8 & 1.634 & 1.043 & 36.2 \\
\hline & 66.5 & 166.5 & 6.2 & 1.614 & 0.984 & 39.0 \\
\hline & 67.5 & 167.5 & 5.8 & 1.505 & 0.846 & 43.8 \\
\hline & 68.5 & 168.5 & 5.1 & 1.655 & 1.070 & 35.3 \\
\hline & 69.5 & 169.5 & 4.8 & 1.601 & 1.027 & 35.9 \\
\hline & 70.5 & 170.5 & 4.8 & 1.627 & 1.065 & 34.5 \\
\hline & 71.5 & 171.5 & 5.6 & 1.550 & 0.979 & 36.8 \\
\hline & 72.5 & 172.5 & 6.9 & 1.546 & 0.914 & 40.9 \\
\hline & 74.0 & 174.0 & 6.3 & 1.448 & 0.824 & 43.1 \\
\hline & 75.0 & 175.0 & 6.0 & 1.571 & 0.930 & 40.8 \\
\hline & 76.5 & 176.5 & 5.6 & 1.540 & 0.924 & 40.0 \\
\hline
\end{tabular}


Table B3. (Cont) LOI data for Lake Butler core 4.

\begin{tabular}{|c|c|c|c|c|c|c|}
\hline Core-Drive & $\begin{array}{c}\text { Depth in } \\
\text { Drive } \\
\text { (cm) }\end{array}$ & $\begin{array}{c}\text { Depth in } \\
\text { Core } \\
\text { (cm) }\end{array}$ & $\begin{array}{c}\text { Organic } \\
\text { Matter } \\
(\%)\end{array}$ & $\begin{array}{c}\text { Wet bulk } \\
\text { Density } \\
\left(\mathrm{g} / \mathrm{cm}^{3}\right)\end{array}$ & $\begin{array}{c}\text { Dry Bulk } \\
\text { Density } \\
\left(\mathrm{g} / \mathrm{cm}^{3}\right)\end{array}$ & $\begin{array}{c}\text { Water } \\
\text { Content } \\
(\%)\end{array}$ \\
\hline \multirow[t]{5}{*}{ LB-16-C4-D2 } & 77.5 & 177.5 & 5.3 & 1.559 & 0.946 & 39.3 \\
\hline & 78.5 & 178.5 & 5.0 & 1.695 & 1.130 & 33.3 \\
\hline & 79.5 & 179.5 & 5.7 & 1.618 & 1.021 & 36.9 \\
\hline & 80.5 & 180.5 & 5.4 & 1.591 & 1.015 & 36.2 \\
\hline & 81.5 & 181.5 & 5.5 & 1.652 & 1.086 & 34.3 \\
\hline \multirow[t]{34}{*}{ LB-16-C4-D3 } & 0.5 & 190.5 & 5.1 & 1.760 & 1.219 & 30.7 \\
\hline & 1.5 & 191.5 & 4.4 & 1.703 & 1.145 & 32.8 \\
\hline & 2.5 & 192.5 & 4.7 & 1.612 & 1.035 & 35.8 \\
\hline & 3.5 & 193.5 & 5.4 & 1.603 & 1.011 & 36.9 \\
\hline & 4.5 & 194.5 & 5.8 & 1.570 & 0.977 & 37.8 \\
\hline & 6.0 & 196.0 & 6.1 & 1.608 & 1.008 & 37.3 \\
\hline & 7.5 & 197.5 & 4.4 & 1.628 & 1.020 & 37.3 \\
\hline & 8.5 & 198.5 & 4.6 & 1.690 & 1.120 & 33.7 \\
\hline & 9.5 & 199.5 & 4.7 & 1.673 & 1.108 & 33.8 \\
\hline & 10.5 & 200.5 & 5.1 & 1.568 & 0.974 & 37.9 \\
\hline & 12.5 & 202.5 & 4.9 & 1.831 & 1.324 & 27.7 \\
\hline & 13.5 & 203.5 & 6.2 & 1.689 & 1.158 & 31.4 \\
\hline & 14.5 & 204.5 & 7.9 & 1.717 & 1.144 & 33.4 \\
\hline & 15.5 & 205.5 & 5.4 & 1.695 & 1.212 & 28.5 \\
\hline & 16.5 & 206.5 & 5.1 & 1.766 & 1.285 & 27.2 \\
\hline & 17.5 & 207.5 & 5.9 & 1.711 & 1.225 & 28.4 \\
\hline & 19.5 & 209.5 & 9.0 & 1.569 & 1.035 & 34.0 \\
\hline & 20.5 & 210.5 & 4.7 & 1.764 & 1.331 & 24.5 \\
\hline & 21.5 & 211.5 & 4.4 & 1.824 & 1.376 & 24.6 \\
\hline & 22.5 & 212.5 & 4.4 & 1.841 & 1.394 & 24.3 \\
\hline & 23.5 & 213.5 & 4.9 & 1.629 & 1.236 & 24.1 \\
\hline & 24.5 & 214.5 & 4.5 & 1.814 & 1.389 & 23.4 \\
\hline & 25.5 & 215.5 & 4.3 & 1.889 & 1.457 & 22.9 \\
\hline & 26.5 & 216.5 & 4.2 & 1.807 & 1.387 & 23.2 \\
\hline & 27.5 & 217.5 & 4.0 & 1.857 & 1.440 & 22.5 \\
\hline & 28.5 & 218.5 & 3.7 & 1.885 & 1.502 & 20.3 \\
\hline & 29.5 & 219.5 & 3.8 & 1.869 & 1.466 & 21.6 \\
\hline & 30.5 & 220.5 & 3.9 & 1.813 & 1.414 & 22.0 \\
\hline & 31.5 & 221.5 & 3.4 & 1.889 & 1.500 & 20.6 \\
\hline & 32.5 & 222.5 & 3.2 & 1.852 & 1.484 & 19.9 \\
\hline & 33.5 & 223.5 & 3.3 & 1.907 & 1.533 & 19.6 \\
\hline & 35.0 & 225.0 & 4.2 & 1.854 & 1.488 & 19.7 \\
\hline & 36.5 & 226.5 & 2.4 & 1.926 & 1.654 & 14.1 \\
\hline & 37.5 & 227.5 & 3.1 & 1.911 & 1.583 & 17.2 \\
\hline
\end{tabular}


Table B3. (Cont) LOI data for Lake Butler core 4.

\begin{tabular}{ccccccc}
\hline \hline \multirow{2}{*}{ Core-Drive } & $\begin{array}{c}\text { Depth in } \\
\text { Drive } \\
(\mathrm{cm})\end{array}$ & $\begin{array}{c}\text { Depth in } \\
\text { Core }\end{array}$ & $\begin{array}{c}\text { Organic } \\
\text { Matter }\end{array}$ & $\begin{array}{c}\text { Wet bulk } \\
\text { Density }\end{array}$ & $\begin{array}{c}\text { Dry Bulk } \\
\text { Density }\end{array}$ & $\begin{array}{c}\text { Water } \\
\text { Content }\end{array}$ \\
\hline LB-16-C4-D3 & (cm $\left.)^{3}\right)$ & $\left(\mathrm{g} / \mathrm{cm}^{3}\right)$ & $(\%)$ \\
\hline & 38.5 & 228.5 & 2.8 & 1.859 & 1.533 & 17.5 \\
& 39.5 & 229.5 & 2.4 & 1.847 & 1.523 & 17.5 \\
& 40.5 & 230.5 & 2.8 & 1.683 & 1.380 & 18.0 \\
& 41.5 & 231.5 & 3.0 & 1.942 & 1.584 & 18.4 \\
42.5 & 232.5 & 3.2 & 1.869 & 1.525 & 18.4 \\
& 43.5 & 233.5 & 3.0 & 1.944 & 1.580 & 18.7 \\
44.5 & 234.5 & 2.9 & 1.995 & 1.637 & 17.9 \\
45.5 & 235.5 & 3.1 & 1.930 & 1.579 & 18.2 \\
46.5 & 236.5 & 3.0 & 1.697 & 1.378 & 18.8 \\
47.5 & 237.5 & 2.1 & 1.895 & 1.614 & 14.8 \\
48.5 & 238.5 & 2.3 & 1.876 & 1.574 & 16.1 \\
49.5 & 239.5 & 2.1 & 1.824 & 1.552 & 14.9 \\
50.5 & 240.5 & 2.1 & 1.703 & 1.480 & 13.1 \\
51.5 & 241.5 & 2.9 & 1.783 & 1.467 & 17.7 \\
52.5 & 242.5 & 2.6 & 1.936 & 1.584 & 18.2 \\
53.5 & 243.5 & 3.1 & 1.986 & 1.612 & 18.8 \\
54.5 & 244.5 & 2.9 & 1.895 & 1.551 & 18.2 \\
55.5 & 245.5 & 2.9 & 1.845 & 1.504 & 18.5 \\
56.5 & 246.5 & 2.7 & 1.999 & 1.654 & 17.3 \\
57.5 & 247.5 & 2.4 & 2.018 & 1.663 & 17.6 \\
58.5 & 248.5 & 1.7 & 1.620 & 1.451 & 10.4 \\
\hline
\end{tabular}


Table B4. Whole-core susceptibility ( $\kappa)$ for Lake Butler core 4.

\begin{tabular}{|c|c|c|c|c|c|c|}
\hline Core-Drive & $\begin{array}{l}\text { Depth in } \\
\text { Drive } \\
\text { (cm) }\end{array}$ & $\begin{array}{l}\text { Depth in } \\
\text { Core } \\
\text { (cm) }\end{array}$ & $\begin{array}{c}\text { Corrected } \\
\text { Depth in Core } \\
\text { (cm) }\end{array}$ & $\begin{array}{c}\kappa \\
\left(10^{-5} \text { Relative }\right. \\
\text { SI Units })\end{array}$ & $\begin{array}{c}\text { Edited } \kappa \\
\left(10^{-5} \text { Relative }\right. \\
\text { SI Units })\end{array}$ & $\begin{array}{c}\text { Edited } \kappa^{*} \\
(\kappa / 2) \\
\left(10^{-5} \text { Relative }\right. \\
\text { SI Units })\end{array}$ \\
\hline \multirow[t]{32}{*}{ LB-16-C4-D1 } & 0 & 0 & 0 & 10.4 & - & - \\
\hline & 3 & 3 & 3 & 21.0 & 21.0 & 10.50 \\
\hline & 6 & 6 & 6 & 20.7 & 20.7 & 10.35 \\
\hline & 9 & 9 & 9 & 19.0 & 19.0 & 9.50 \\
\hline & 12 & 12 & 12 & 16.7 & 16.7 & 8.35 \\
\hline & 15 & 15 & 15 & 19.6 & 19.6 & 9.80 \\
\hline & 18 & 18 & 18 & 21.1 & 21.1 & 10.55 \\
\hline & 21 & 21 & 21 & 20.5 & 20.5 & 10.25 \\
\hline & 24 & 24 & 24 & 21.1 & 21.1 & 10.55 \\
\hline & 27 & 27 & 27 & 24.3 & 24.3 & 12.15 \\
\hline & 30 & 30 & 30 & 24.7 & 24.7 & 12.35 \\
\hline & 33 & 33 & 33 & 26.2 & 26.2 & 13.10 \\
\hline & 36 & 36 & 36 & 29.4 & 29.4 & 14.70 \\
\hline & 39 & 39 & 39 & 27.3 & 27.3 & 13.65 \\
\hline & 42 & 42 & 42 & 25.6 & 25.6 & 12.80 \\
\hline & 45 & 45 & 45 & 27.3 & 27.3 & 13.65 \\
\hline & 48 & 48 & 48 & 23.3 & 23.3 & 11.65 \\
\hline & 51 & 51 & 51 & 21.4 & 21.4 & 10.70 \\
\hline & 54 & 54 & 54 & 24.3 & 24.3 & 12.15 \\
\hline & 57 & 57 & 57 & 27.9 & 27.9 & 13.95 \\
\hline & 60 & 60 & 60 & 28.6 & 28.6 & 14.30 \\
\hline & 63 & 63 & 63 & 23.4 & 23.4 & 11.70 \\
\hline & 66 & 66 & 66 & 19.5 & 19.5 & 9.75 \\
\hline & 69 & 69 & 69 & 17.4 & 17.4 & 8.70 \\
\hline & 72 & 72 & 72 & 21.2 & 21.2 & 10.60 \\
\hline & 75 & 75 & 75 & 26.4 & 26.4 & 13.20 \\
\hline & 78 & 78 & 78 & 26.0 & 26.0 & 13.00 \\
\hline & 81 & 81 & 81 & 25.5 & 25.5 & 12.75 \\
\hline & 84 & 84 & 84 & 24.1 & 24.1 & 12.05 \\
\hline & 87 & 87 & 87 & 22.6 & 22.6 & 11.30 \\
\hline & 90 & 90 & 90 & 20.7 & 20.7 & 10.35 \\
\hline & 93 & 93 & - & 11.2 & - & - \\
\hline \multirow[t]{7}{*}{ LB-16-C4-D2 } & 0 & 100 & - & 8.7 & - & - \\
\hline & 3 & 103 & 103 & 26.4 & 26.4 & 13.20 \\
\hline & 6 & 106 & 106 & 27.4 & 27.4 & 13.70 \\
\hline & 9 & 109 & 109 & 23.4 & 23.4 & 11.70 \\
\hline & 12 & 112 & 112 & 20.4 & 20.4 & 10.20 \\
\hline & 15 & 115 & 115 & 25.3 & 25.3 & 12.65 \\
\hline & 18 & 118 & 118 & 25.1 & 25.1 & 12.55 \\
\hline
\end{tabular}


Table B4. (Cont) Whole-core susceptibility (к) for Lake Butler core 4.

\begin{tabular}{|c|c|c|c|c|c|c|}
\hline Core-Drive & $\begin{array}{l}\text { Depth in } \\
\text { Drive } \\
\text { (cm) }\end{array}$ & $\begin{array}{l}\text { Depth in } \\
\text { Core } \\
\text { (cm) }\end{array}$ & $\begin{array}{c}\text { Corrected } \\
\text { Depth in Core } \\
\text { (cm) }\end{array}$ & $\begin{array}{c}\kappa \\
\left(10^{-5} \text { Relative }\right. \\
\text { SI Units })\end{array}$ & $\begin{array}{c}\text { Edited } \kappa \\
\left(10^{-5} \text { Relative }\right. \\
\text { SI Units })\end{array}$ & $\begin{array}{c}\text { Edited } \kappa^{*} \\
(\kappa / 2) \\
\left(10^{-5} \text { Relative }\right. \\
\text { SI Units })\end{array}$ \\
\hline \multirow[t]{23}{*}{ LB-16-C4-D2 } & 21 & 121 & 121 & 24.8 & 24.8 & 12.40 \\
\hline & 24 & 124 & 124 & 25.6 & 25.6 & 12.80 \\
\hline & 27 & 127 & 127 & 27.4 & 27.4 & 13.70 \\
\hline & 30 & 130 & 130 & 25.6 & 25.6 & 12.80 \\
\hline & 33 & 133 & 133 & 25.2 & 25.2 & 12.60 \\
\hline & 36 & 136 & 136 & 25.7 & 25.7 & 12.85 \\
\hline & 39 & 139 & 139 & 24.6 & 24.6 & 12.30 \\
\hline & 42 & 142 & 142 & 22.8 & 22.8 & 11.40 \\
\hline & 45 & 145 & 145 & 23.8 & 23.8 & 11.90 \\
\hline & 48 & 148 & 148 & 25.2 & 25.2 & 12.60 \\
\hline & 51 & 151 & 151 & 25.9 & 25.9 & 12.95 \\
\hline & 54 & 154 & 154 & 24.7 & 24.7 & 12.35 \\
\hline & 57 & 157 & 157 & 25.8 & 25.8 & 12.90 \\
\hline & 60 & 160 & 160 & 24.6 & 24.6 & 12.30 \\
\hline & 63 & 163 & 163 & 23.6 & 23.6 & 11.80 \\
\hline & 66 & 166 & 166 & 24.1 & 24.1 & 12.05 \\
\hline & 69 & 169 & 169 & 24.2 & 24.2 & 12.10 \\
\hline & 72 & 172 & 172 & 25.1 & 25.1 & 12.55 \\
\hline & 75 & 175 & 175 & 27.2 & 27.2 & 13.60 \\
\hline & 78 & 178 & 178 & 25.6 & 25.6 & 12.80 \\
\hline & 81 & 181 & 181 & 26.3 & 26.3 & 13.15 \\
\hline & 84 & 184 & 184 & 19.2 & 19.2 & 9.60 \\
\hline & 87 & 187 & - & 4.1 & - & - \\
\hline \multirow[t]{15}{*}{ LB-16-C4-D3 } & 0 & 190 & - & 9.3 & - & - \\
\hline & 3 & 193 & 193 & 25.0 & 25.0 & 12.50 \\
\hline & 6 & 196 & 196 & 32.6 & 32.6 & 16.30 \\
\hline & 9 & 199 & 199 & 33.8 & 33.8 & 16.90 \\
\hline & 12 & 202 & 202 & 47.9 & 47.9 & 23.95 \\
\hline & 15 & 205 & 205 & 82.6 & 82.6 & 41.30 \\
\hline & 18 & 208 & 208 & 66.6 & 66.6 & 33.30 \\
\hline & 21 & 211 & 211 & 57.5 & 57.5 & 28.75 \\
\hline & 24 & 214 & 214 & 62.6 & 62.6 & 31.30 \\
\hline & 27 & 217 & 217 & 66.0 & 66.0 & 33.00 \\
\hline & 30 & 220 & 220 & 66.3 & 66.3 & 33.15 \\
\hline & 33 & 223 & 223 & 63.8 & 63.8 & 31.90 \\
\hline & 36 & 226 & 226 & 55.9 & 55.9 & 27.95 \\
\hline & 39 & 229 & 229 & 65.5 & 65.5 & 32.75 \\
\hline & 42 & 232 & 232 & 77.7 & 77.7 & 38.85 \\
\hline
\end{tabular}


Table B4. (Cont) Whole-core susceptibility ( $\kappa)$ for Lake Butler core 4.

\begin{tabular}{|c|c|c|c|c|c|c|}
\hline Core-Drive & $\begin{array}{l}\text { Depth in } \\
\text { Drive } \\
\text { (cm) }\end{array}$ & $\begin{array}{l}\text { Depth in } \\
\text { Core } \\
\text { (cm) }\end{array}$ & $\begin{array}{c}\text { Corrected } \\
\text { Depth in Core } \\
\text { (cm) }\end{array}$ & $\begin{array}{c}\kappa \\
\left(10^{-5} \text { Relative }\right. \\
\text { SI Units })\end{array}$ & $\begin{array}{c}\text { Edited } \kappa \\
\left(10^{-5} \text { Relative }\right. \\
\text { SI Units })\end{array}$ & $\begin{array}{c}\text { Edited } \kappa^{*} \\
(\kappa / 2) \\
\left(10^{-5} \text { Relative }\right. \\
\text { SI Units })\end{array}$ \\
\hline \multirow[t]{6}{*}{ LB-16-C4-D3 } & 45 & 235 & 235 & 67.6 & 67.6 & 33.80 \\
\hline & 48 & 238 & 238 & 61.3 & 61.3 & 30.65 \\
\hline & 51 & 241 & 241 & 58.5 & 58.5 & 29.25 \\
\hline & 54 & 244 & 244 & 59.2 & 59.2 & 29.60 \\
\hline & 57 & 247 & 247 & 64.5 & 64.5 & 32.25 \\
\hline & 60 & 250 & - & 51.4 & - & - \\
\hline
\end{tabular}


Table B5. LOI data for Lake Butler core 7.

\begin{tabular}{|c|c|c|c|c|c|}
\hline Core-Drive & $\begin{array}{l}\text { Depth } \\
(\mathrm{cm})\end{array}$ & $\begin{array}{c}\text { Organic } \\
\text { Matter } \\
\text { (\%) }\end{array}$ & $\begin{array}{c}\text { Wet bulk } \\
\text { Density } \\
\left(\mathrm{g} / \mathrm{cm}^{3}\right)\end{array}$ & $\begin{array}{c}\text { Dry Bulk } \\
\text { Density } \\
\left(\mathrm{g} / \mathrm{cm}^{3}\right)\end{array}$ & $\begin{array}{c}\text { Water } \\
\text { Content } \\
(\%)\end{array}$ \\
\hline \multirow[t]{42}{*}{ LB-16-C7 } & 0.5 & 6.0 & 1.539 & 0.926 & 39.8 \\
\hline & 1.5 & 6.1 & 1.472 & 0.881 & 40.1 \\
\hline & 2.5 & 5.9 & 1.498 & 0.900 & 39.9 \\
\hline & 3.5 & 6.4 & 1.403 & 0.771 & 45.0 \\
\hline & 4.5 & 5.9 & 1.462 & 0.843 & 42.3 \\
\hline & 5.5 & 6.0 & 1.477 & 0.873 & 40.9 \\
\hline & 6.5 & 6.6 & 1.483 & 0.890 & 40.0 \\
\hline & 7.5 & 7.8 & 1.423 & 0.785 & 44.8 \\
\hline & 8.5 & 7.0 & 1.408 & 0.714 & 49.3 \\
\hline & 9.5 & 6.8 & 1.405 & 0.703 & 50.0 \\
\hline & 10.5 & 6.1 & 1.445 & 0.802 & 44.5 \\
\hline & 11.5 & 5.7 & 1.476 & 0.841 & 43.0 \\
\hline & 12.5 & 5.4 & 1.505 & 0.926 & 38.5 \\
\hline & 13.5 & 7.5 & 1.364 & 0.706 & 48.2 \\
\hline & 14.5 & 6.2 & 1.438 & 0.790 & 45.1 \\
\hline & 15.5 & 4.4 & 1.627 & 1.091 & 32.9 \\
\hline & 16.5 & 6.1 & 1.505 & 0.900 & 40.2 \\
\hline & 17.5 & 6.1 & 1.440 & 0.754 & 47.6 \\
\hline & 18.5 & 4.9 & 1.552 & 0.953 & 38.6 \\
\hline & 19.5 & 6.1 & 1.436 & 0.831 & 42.1 \\
\hline & 20.5 & 6.4 & 1.457 & 0.813 & 44.2 \\
\hline & 21.5 & 6.4 & 1.425 & 0.752 & 47.2 \\
\hline & 22.5 & 5.8 & 1.470 & 0.790 & 46.3 \\
\hline & 23.5 & 5.7 & 1.386 & 0.771 & 44.4 \\
\hline & 24.5 & 5.4 & 1.518 & 0.948 & 37.5 \\
\hline & 25.5 & 5.3 & 1.507 & 0.931 & 38.2 \\
\hline & 26.5 & 5.5 & 1.509 & 0.879 & 41.7 \\
\hline & 27.5 & 5.1 & 1.520 & 0.930 & 38.8 \\
\hline & 28.5 & 4.6 & 1.561 & 1.034 & 33.8 \\
\hline & 29.5 & 5.1 & 1.497 & 0.910 & 39.2 \\
\hline & 30.5 & 6.3 & 1.466 & 0.805 & 45.1 \\
\hline & 31.5 & 6.5 & 1.361 & 0.680 & 50.0 \\
\hline & 32.5 & 6.2 & 1.367 & 0.722 & 47.2 \\
\hline & 33.5 & 7.2 & 1.326 & 0.636 & 52.0 \\
\hline & 34.5 & 7.9 & 1.412 & 0.734 & 48.0 \\
\hline & 35.5 & 6.5 & 1.423 & 0.803 & 43.6 \\
\hline & 36.5 & 9.4 & 1.392 & 0.681 & 51.1 \\
\hline & 37.5 & 10.0 & 1.351 & 0.580 & 57.1 \\
\hline & 38.5 & 7.1 & 1.411 & 0.763 & 45.9 \\
\hline & 39.5 & 7.0 & 1.442 & 0.799 & 44.6 \\
\hline & 40.5 & 5.8 & 1.502 & 0.921 & 38.7 \\
\hline & 41.5 & 6.1 & 1.513 & 0.906 & 40.1 \\
\hline
\end{tabular}


Table B5. (Cont) LOI data for Lake Butler core 7.

\begin{tabular}{|c|c|c|c|c|c|}
\hline Core-Drive & $\begin{array}{l}\text { Depth } \\
(\mathrm{cm})\end{array}$ & $\begin{array}{c}\text { Organic } \\
\text { Matter } \\
(\%)\end{array}$ & $\begin{array}{c}\text { Wet bulk } \\
\text { Density } \\
\left(\mathrm{g} / \mathrm{cm}^{3}\right)\end{array}$ & $\begin{array}{c}\text { Dry Bulk } \\
\text { Density } \\
\left(\mathrm{g} / \mathrm{cm}^{3}\right)\end{array}$ & $\begin{array}{c}\text { Water } \\
\text { Content } \\
(\%)\end{array}$ \\
\hline \multirow[t]{40}{*}{ LB-16-C7 } & 42.5 & 4.8 & 1.527 & 0.996 & 34.8 \\
\hline & 43.5 & 6.7 & 1.400 & 0.810 & 42.1 \\
\hline & 44.5 & 11.4 & 1.336 & 0.595 & 55.5 \\
\hline & 45.5 & 6.2 & 1.443 & 0.853 & 40.9 \\
\hline & 46.5 & 5.0 & 1.469 & 0.914 & 37.8 \\
\hline & 47.5 & 6.9 & 1.531 & 0.878 & 42.7 \\
\hline & 48.5 & 7.0 & 1.421 & 0.800 & 43.7 \\
\hline & 49.5 & 5.2 & 1.487 & 0.897 & 39.7 \\
\hline & 50.5 & 6.6 & 1.347 & 0.667 & 50.5 \\
\hline & 51.5 & 4.8 & 1.514 & 0.924 & 39.0 \\
\hline & 52.5 & 5.6 & 1.494 & 0.917 & 38.6 \\
\hline & 53.5 & 5.5 & 1.535 & 0.907 & 40.9 \\
\hline & 54.5 & 6.1 & 1.431 & 0.820 & 42.7 \\
\hline & 55.5 & 7.3 & 1.294 & 0.593 & 54.2 \\
\hline & 56.5 & 6.3 & 1.414 & 0.764 & 46.0 \\
\hline & 57.5 & 6.4 & 1.381 & 0.724 & 47.6 \\
\hline & 58.5 & 6.1 & 1.383 & 0.738 & 46.6 \\
\hline & 59.5 & 6.1 & 1.468 & 0.866 & 41.0 \\
\hline & 60.5 & 6.9 & 1.302 & 0.652 & 49.9 \\
\hline & 61.5 & 7.5 & 1.332 & 0.628 & 52.9 \\
\hline & 62.5 & 5.8 & 1.406 & 0.796 & 43.4 \\
\hline & 63.5 & 5.9 & 1.364 & 0.710 & 47.9 \\
\hline & 64.5 & 5.9 & 1.463 & 0.817 & 44.2 \\
\hline & 65.5 & 7.8 & 1.271 & 0.486 & 61.8 \\
\hline & 66.5 & 5.9 & 1.406 & 0.717 & 49.0 \\
\hline & 67.5 & 8.6 & 1.285 & 0.526 & 59.1 \\
\hline & 68.5 & 7.6 & 1.196 & 0.503 & 57.9 \\
\hline & 69.5 & 6.0 & 1.371 & 0.682 & 50.3 \\
\hline & 70.5 & 5.6 & 1.514 & 0.853 & 43.7 \\
\hline & 71.5 & 7.0 & 1.120 & 0.473 & 57.8 \\
\hline & 72.5 & 5.9 & 1.429 & 0.764 & 46.5 \\
\hline & 73.5 & 5.2 & 1.370 & 0.782 & 42.9 \\
\hline & 74.5 & 5.8 & 1.484 & 0.873 & 41.2 \\
\hline & 75.5 & 4.8 & 1.471 & 0.972 & 33.9 \\
\hline & 76.5 & 6.3 & 1.441 & 0.882 & 38.8 \\
\hline & 77.5 & 5.5 & 1.593 & 1.043 & 34.5 \\
\hline & 78.5 & 5.7 & 1.565 & 1.004 & 35.8 \\
\hline & 79.5 & 5.5 & 1.556 & 1.016 & 34.7 \\
\hline & 80.5 & 5.3 & 1.461 & 0.955 & 34.6 \\
\hline & 81.5 & 5.9 & 1.478 & 0.920 & 37.8 \\
\hline
\end{tabular}


Table B5. (Cont) LOI data for Lake Butler core 7.

\begin{tabular}{cccccc}
\hline \hline \multirow{2}{*}{ Core-Drive } & Depth & $\begin{array}{c}\text { Organic } \\
\text { Matter }\end{array}$ & $\begin{array}{c}\text { Wet bulk } \\
\text { Density }\end{array}$ & $\begin{array}{c}\text { Dry Bulk } \\
\text { Density } \\
(\mathrm{g})\end{array}$ & $\begin{array}{c}\text { Water } \\
\text { Content }\end{array}$ \\
& $\left(\mathrm{g} / \mathrm{cm}^{3}\right)$ & $\left(\mathrm{g} / \mathrm{cm}^{3}\right)$ & $(\%)$ \\
\hline LB-16-C7 & 82.5 & 6.2 & 1.424 & 0.858 & 39.7 \\
& 83.5 & 5.7 & 1.384 & 0.887 & 35.9 \\
& 84.5 & 6.1 & 1.399 & 0.782 & 44.1 \\
& 85.5 & 6.0 & 1.359 & 0.756 & 44.4 \\
& 86.5 & 6.1 & 1.421 & 0.826 & 41.9 \\
& 87.5 & 5.6 & 1.405 & 0.844 & 39.9 \\
& 88.5 & 5.2 & 1.392 & 0.890 & 36.1 \\
& 89.5 & 5.4 & 1.349 & 0.865 & 35.9 \\
& 90.5 & 5.4 & 1.430 & 0.886 & 38.0 \\
& 91.5 & 5.7 & 1.338 & 0.849 & 36.5 \\
92.5 & 5.4 & 1.501 & 1.017 & 32.2 \\
& 93.5 & 5.5 & 1.463 & 0.997 & 31.9 \\
& 94.5 & 5.3 & 1.642 & 1.151 & 29.9 \\
95.5 & 5.2 & 1.490 & 1.042 & 30.1 \\
& 96.5 & 5.4 & 1.759 & 1.283 & 27.1 \\
97.5 & 5.0 & 1.518 & 1.087 & 28.4 \\
\hline
\end{tabular}


Table B6. Whole-core susceptibility $(\kappa)$ for Lake Butler core 7.

\begin{tabular}{|c|c|c|c|c|c|}
\hline \multirow{2}{*}{ Core-Drive } & $\begin{array}{l}\text { Depth in } \\
\text { Drive }\end{array}$ & $\begin{array}{l}\text { Depth in } \\
\text { Core }\end{array}$ & $\begin{array}{c}\text { Corrected } \\
\text { Depth in Core }\end{array}$ & $\kappa$ & Edited $\kappa$ \\
\hline & $(\mathrm{cm})$ & $(\mathrm{cm})$ & $(\mathrm{cm})$ & $\begin{array}{l}\left(10^{-5} \text { Relative }\right. \\
\text { SI Units })\end{array}$ & $\begin{array}{c}\left(10^{-5} \text { Relative SI }\right. \\
\text { Units })\end{array}$ \\
\hline \multirow[t]{34}{*}{ LB-16-C7 } & 0 & 0 & - & 1.5 & - \\
\hline & 3 & 3 & 3 & 8.3 & 8.3 \\
\hline & 6 & 6 & 6 & 10.8 & 10.8 \\
\hline & 9 & 9 & 9 & 11.3 & 11.3 \\
\hline & 12 & 12 & 12 & 10.5 & 10.5 \\
\hline & 15 & 15 & 15 & 11.7 & 11.7 \\
\hline & 18 & 18 & 18 & 12.5 & 12.5 \\
\hline & 21 & 21 & 21 & 11.1 & 11.1 \\
\hline & 24 & 24 & 24 & 10.9 & 10.9 \\
\hline & 27 & 27 & 27 & 12.9 & 12.9 \\
\hline & 30 & 30 & 30 & 13.9 & 13.9 \\
\hline & 33 & 33 & 33 & 11.8 & 11.8 \\
\hline & 36 & 36 & 36 & 10.5 & 10.5 \\
\hline & 39 & 39 & 39 & 12.7 & 12.7 \\
\hline & 42 & 42 & 42 & 14.4 & 14.4 \\
\hline & 45 & 45 & 45 & 14.8 & 14.8 \\
\hline & 48 & 48 & 48 & 14.4 & 14.4 \\
\hline & 51 & 51 & 51 & 13.9 & 13.9 \\
\hline & 54 & 54 & 54 & 13.6 & 13.6 \\
\hline & 57 & 57 & 57 & 12.5 & 12.5 \\
\hline & 60 & 60 & 60 & 11.2 & 11.2 \\
\hline & 63 & 63 & 63 & 11.8 & 11.8 \\
\hline & 66 & 66 & 66 & 10.3 & 10.3 \\
\hline & 69 & 69 & 69 & 9.2 & 9.2 \\
\hline & 72 & 72 & 72 & 11.6 & 11.6 \\
\hline & 75 & 75 & 75 & 16.3 & 16.3 \\
\hline & 78 & 78 & 78 & 22.8 & 22.8 \\
\hline & 81 & 81 & 81 & 25.3 & 25.3 \\
\hline & 84 & 84 & 84 & 25.6 & 25.6 \\
\hline & 87 & 87 & 87 & 22.5 & 22.5 \\
\hline & 90 & 90 & 90 & 22.5 & 22.5 \\
\hline & 93 & 93 & 93 & 24.0 & 24.0 \\
\hline & 96 & 96 & 96 & 25.1 & 25.1 \\
\hline & 99 & 99 & - & 18.7 & - \\
\hline
\end{tabular}


Table B7. LOI data for Lake Litchfield core 1.

\begin{tabular}{|c|c|c|c|c|c|}
\hline Core-Drive & $(\mathrm{cm})$ & $\begin{array}{c}\text { Organic } \\
\text { Matter } \\
\\
(\%) \\
\end{array}$ & $\begin{array}{c}\text { Wet bulk } \\
\text { Density } \\
\left(\mathrm{g} / \mathrm{cm}^{3}\right)\end{array}$ & $\begin{array}{c}\text { Dry Bulk } \\
\text { Density } \\
\left(\mathrm{g} / \mathrm{cm}^{3}\right) \\
\end{array}$ & $\begin{array}{c}\text { Water } \\
\text { Content } \\
(\%) \\
\end{array}$ \\
\hline \multirow[t]{39}{*}{ LL-16-C1 } & 0.5 & 5.1 & 1.515 & 0.904 & 40.3 \\
\hline & 1.5 & 4.9 & 1.569 & 1.026 & 34.6 \\
\hline & 2.5 & 4.7 & 1.584 & 1.015 & 35.9 \\
\hline & 3.5 & 4.9 & 1.421 & 0.899 & 36.7 \\
\hline & 4.5 & 5.2 & 1.557 & 0.946 & 39.2 \\
\hline & 5.5 & 4.6 & 1.487 & 0.912 & 38.7 \\
\hline & 6.5 & 4.3 & 1.580 & 1.011 & 36.0 \\
\hline & 7.5 & 4.5 & 1.558 & 0.978 & 37.2 \\
\hline & 8.5 & 5.4 & 1.483 & 0.912 & 38.5 \\
\hline & 9.5 & 2.8 & 1.657 & 1.161 & 29.9 \\
\hline & 10.5 & 4.3 & 1.610 & 1.027 & 36.2 \\
\hline & 11.5 & 5.6 & 1.484 & 0.915 & 38.3 \\
\hline & 12.5 & 4.2 & 1.592 & 1.050 & 34.0 \\
\hline & 13.5 & 5.3 & 1.560 & 0.938 & 39.9 \\
\hline & 14.5 & 6.0 & 1.227 & 0.598 & 51.3 \\
\hline & 15.5 & 4.6 & 1.480 & 0.847 & 42.8 \\
\hline & 16.5 & 4.3 & 1.591 & 0.996 & 37.4 \\
\hline & 17.5 & 5.5 & 1.511 & 0.861 & 43.0 \\
\hline & 18.5 & 5.1 & 1.385 & 0.749 & 45.9 \\
\hline & 19.5 & 3.6 & 1.552 & 0.996 & 35.8 \\
\hline & 20.5 & 4.4 & 1.461 & 0.861 & 41.1 \\
\hline & 21.5 & 5.9 & 1.281 & 0.596 & 53.5 \\
\hline & 22.5 & 3.3 & 1.604 & 1.084 & 32.4 \\
\hline & 23.5 & 3.7 & 1.641 & 1.083 & 34.0 \\
\hline & 24.5 & 4.7 & 1.432 & 0.854 & 40.4 \\
\hline & 25.5 & 4.1 & 1.543 & 1.013 & 34.3 \\
\hline & 26.5 & 3.8 & 1.619 & 1.074 & 33.7 \\
\hline & 27.5 & 5.0 & 1.541 & 0.969 & 37.1 \\
\hline & 28.5 & 4.7 & 1.592 & 0.986 & 38.1 \\
\hline & 29.5 & 5.3 & 1.520 & 0.924 & 39.2 \\
\hline & 30.5 & 4.6 & 1.568 & 0.970 & 38.1 \\
\hline & 31.5 & 3.7 & 1.655 & 1.143 & 30.9 \\
\hline & 32.5 & 4.0 & 1.663 & 1.110 & 33.3 \\
\hline & 33.5 & 3.9 & 1.514 & 0.990 & 34.6 \\
\hline & 34.5 & 1.5 & 1.774 & 1.368 & 22.9 \\
\hline & 35.5 & 4.1 & 1.615 & 1.064 & 34.1 \\
\hline & 36.5 & 3.8 & 1.574 & 1.051 & 33.2 \\
\hline & 37.5 & 2.0 & 1.761 & 1.319 & 25.1 \\
\hline & 38.5 & 4.3 & 1.644 & 1.085 & 34.0 \\
\hline
\end{tabular}


Table B7. (Cont) LOI data for Lake Litchfield core 1.

\begin{tabular}{|c|c|c|c|c|c|}
\hline Core-Drive & $\begin{array}{l}\text { Depth } \\
(\mathrm{cm})\end{array}$ & $\begin{array}{c}\text { Organic } \\
\text { Matter } \\
(\%)\end{array}$ & $\begin{array}{c}\text { Wet bulk } \\
\text { Density } \\
\left(\mathrm{g} / \mathrm{cm}^{3}\right)\end{array}$ & $\begin{array}{c}\text { Dry Bulk } \\
\text { Density } \\
\left(\mathrm{g} / \mathrm{cm}^{3}\right)\end{array}$ & $\begin{array}{c}\text { Water } \\
\text { Content } \\
\text { (\%) }\end{array}$ \\
\hline \multirow[t]{39}{*}{ LL-16-C1 } & 39.5 & 4.0 & 1.636 & 1.069 & 34.7 \\
\hline & 40.5 & 4.7 & 1.537 & 0.937 & 39.0 \\
\hline & 42.0 & 6.2 & 1.376 & 0.694 & 49.6 \\
\hline & 43.0 & 6.1 & 1.395 & 0.773 & 44.6 \\
\hline & 44.0 & 8.2 & 1.219 & 0.478 & 60.8 \\
\hline & 45.0 & 4.9 & 1.500 & 0.920 & 38.7 \\
\hline & 46.5 & 6.4 & 1.395 & 0.761 & 45.4 \\
\hline & 47.5 & 5.9 & 1.256 & 0.613 & 51.2 \\
\hline & 48.5 & 4.5 & 1.572 & 0.985 & 37.3 \\
\hline & 49.5 & 3.7 & 1.712 & 1.176 & 31.3 \\
\hline & 50.5 & 3.7 & 1.610 & 1.086 & 32.5 \\
\hline & 51.5 & 3.7 & 1.655 & 1.158 & 30.0 \\
\hline & 52.5 & 3.9 & 1.703 & 1.166 & 31.5 \\
\hline & 53.5 & 4.1 & 1.632 & 1.054 & 35.4 \\
\hline & 54.5 & 3.5 & 1.671 & 1.140 & 31.8 \\
\hline & 55.5 & 1.9 & 1.784 & 1.366 & 23.4 \\
\hline & 56.5 & 4.7 & 1.669 & 1.089 & 34.8 \\
\hline & 57.5 & 4.0 & 1.680 & 1.114 & 33.7 \\
\hline & 58.5 & 5.0 & 1.582 & 0.993 & 37.2 \\
\hline & 59.5 & 5.0 & 1.407 & 0.898 & 36.2 \\
\hline & 61.0 & 7.1 & 1.341 & 0.590 & 56.0 \\
\hline & 62.5 & 4.8 & 1.566 & 0.962 & 38.6 \\
\hline & 63.5 & 4.7 & 1.595 & 1.015 & 36.4 \\
\hline & 64.5 & 13.3 & 1.158 & 0.368 & 68.2 \\
\hline & 65.5 & 5.7 & 1.430 & 0.861 & 39.8 \\
\hline & 66.5 & 5.3 & 1.586 & 0.970 & 38.8 \\
\hline & 67.5 & 6.0 & 1.434 & 0.856 & 40.3 \\
\hline & 68.5 & 4.9 & 1.562 & 0.993 & 36.4 \\
\hline & 69.5 & 5.4 & 1.653 & 1.028 & 37.8 \\
\hline & 70.5 & 4.7 & 1.614 & 1.061 & 34.3 \\
\hline & 71.5 & 6.8 & 1.440 & 0.780 & 45.8 \\
\hline & 72.5 & 5.2 & 1.556 & 0.908 & 41.6 \\
\hline & 73.5 & 6.2 & 1.366 & 0.731 & 46.5 \\
\hline & 74.5 & 5.3 & 1.530 & 0.893 & 41.6 \\
\hline & 75.5 & 5.5 & 1.344 & 0.887 & 34.0 \\
\hline & 76.5 & 4.7 & 1.738 & 1.246 & 28.3 \\
\hline & 77.5 & 4.1 & 1.723 & 1.272 & 26.2 \\
\hline & 78.5 & 3.3 & 1.718 & 1.271 & 26.0 \\
\hline & 79.5 & 2.9 & 1.838 & 1.400 & 23.8 \\
\hline
\end{tabular}


Table B7. LOI data for Lake Litchfield core 1.

\begin{tabular}{|c|c|c|c|c|c|}
\hline Core-Drive & $\begin{array}{l}\text { Depth } \\
(\mathrm{cm})\end{array}$ & $\begin{array}{c}\text { Organic } \\
\text { Matter } \\
(\%)\end{array}$ & $\begin{array}{c}\text { Wet bulk } \\
\text { Density } \\
\left(\mathrm{g} / \mathrm{cm}^{3}\right)\end{array}$ & $\begin{array}{c}\text { Dry Bulk } \\
\text { Density } \\
\left(\mathrm{g} / \mathrm{cm}^{3}\right)\end{array}$ & $\begin{array}{c}\text { Water } \\
\text { Content } \\
\text { (\%) }\end{array}$ \\
\hline \multirow[t]{39}{*}{ LL-16-C1 } & 80.5 & 3.1 & 1.738 & 1.324 & 23.8 \\
\hline & 81.5 & 3.1 & 1.683 & 1.263 & 25.0 \\
\hline & 82.5 & 3.5 & 1.607 & 1.208 & 24.8 \\
\hline & 83.5 & 3.4 & 1.797 & 1.337 & 25.6 \\
\hline & 84.5 & 3.2 & 1.444 & 1.071 & 25.8 \\
\hline & 85.5 & 3.2 & 1.657 & 1.236 & 25.4 \\
\hline & 86.5 & 3.4 & 1.828 & 1.371 & 25.0 \\
\hline & 87.5 & 3.2 & 1.842 & 1.410 & 23.5 \\
\hline & 88.5 & 3.3 & 1.712 & 1.331 & 22.3 \\
\hline & 89.5 & 3.2 & 1.803 & 1.354 & 24.9 \\
\hline & 90.5 & 3.2 & 1.756 & 1.340 & 23.7 \\
\hline & 91.5 & 3.4 & 1.815 & 1.371 & 24.5 \\
\hline & 92.5 & 3.3 & 1.822 & 1.381 & 24.2 \\
\hline & 93.5 & 3.2 & 1.818 & 1.374 & 24.4 \\
\hline & 94.5 & 3.3 & 1.879 & 1.433 & 23.7 \\
\hline & 95.5 & 2.8 & 1.865 & 1.456 & 21.9 \\
\hline & 96.5 & 2.6 & 1.728 & 1.346 & 22.1 \\
\hline & 97.5 & 3.1 & 1.808 & 1.364 & 24.6 \\
\hline & 98.5 & 3.2 & 1.750 & 1.290 & 26.3 \\
\hline & 99.5 & 3.1 & 1.766 & 1.328 & 24.8 \\
\hline & 100.5 & 3.0 & 1.846 & 1.422 & 23.0 \\
\hline & 101.5 & 2.5 & 1.843 & 1.454 & 21.1 \\
\hline & 102.5 & 1.7 & 1.842 & 1.498 & 18.7 \\
\hline & 103.5 & 2.0 & 1.829 & 1.477 & 19.2 \\
\hline & 105.5 & 4.0 & 1.759 & 1.329 & 24.4 \\
\hline & 106.5 & 4.3 & 1.716 & 1.270 & 26.0 \\
\hline & 107.5 & 4.3 & 1.722 & 1.290 & 25.1 \\
\hline & 108.5 & 4.0 & 1.731 & 1.305 & 24.6 \\
\hline & 109.5 & 4.3 & 1.652 & 1.207 & 26.9 \\
\hline & 110.5 & 3.3 & 1.794 & 1.377 & 23.2 \\
\hline & 111.5 & 3.4 & 1.684 & 1.270 & 24.6 \\
\hline & 112.5 & 5.9 & 1.574 & 1.090 & 30.7 \\
\hline & 113.5 & 5.7 & 1.599 & 1.120 & 30.0 \\
\hline & 114.5 & 3.5 & 1.716 & 1.302 & 24.1 \\
\hline & 116.5 & 4.6 & 1.646 & 1.167 & 29.1 \\
\hline & 117.5 & 2.8 & 1.654 & 1.291 & 21.9 \\
\hline & 118.5 & 2.8 & 1.689 & 1.304 & 22.8 \\
\hline & 119.5 & 3.1 & 1.877 & 1.442 & 23.2 \\
\hline & 120.5 & 3.5 & 1.773 & 1.338 & 24.5 \\
\hline
\end{tabular}


Table B7. LOI data for Lake Litchfield core 1.

\begin{tabular}{cccccc}
\hline \hline \multirow{2}{*}{ Core-Drive } & Depth & $\begin{array}{c}\text { Organic } \\
\text { Matter }\end{array}$ & $\begin{array}{c}\text { Wet bulk } \\
\text { Density }\end{array}$ & $\begin{array}{c}\text { Dry Bulk } \\
\text { Density }\end{array}$ & $\begin{array}{c}\text { Water } \\
\text { Content }\end{array}$ \\
& & & & \\
& $(\mathrm{cm})$ & $(\%)$ & $\left(\mathrm{g} / \mathrm{cm}^{3}\right)$ & $\left(\mathrm{g} / \mathrm{cm}^{3}\right)$ & $(\%)$ \\
\hline LL-16-C1 & 122.5 & 2.3 & 1.882 & 1.500 & 20.3 \\
& 123.5 & 2.3 & 1.773 & 1.456 & 17.9 \\
& 124.5 & 2.1 & 1.863 & 1.531 & 17.8 \\
& 125.5 & 2.2 & 1.945 & 1.598 & 17.8 \\
& 126.5 & 2.3 & 1.584 & 1.283 & 19.0 \\
127.5 & 2.5 & 1.734 & 1.384 & 20.2 \\
128.5 & 4.3 & 1.603 & 1.180 & 26.4 \\
129.5 & 2.2 & 1.776 & 1.424 & 19.8 \\
131.5 & 2.2 & 1.656 & 1.401 & 15.4 \\
132.5 & 2.1 & 1.640 & 1.369 & 16.5 \\
133.5 & 2.4 & 1.707 & 1.391 & 18.5 \\
134.5 & 2.2 & 1.812 & 1.470 & 18.9 \\
135.5 & 2.2 & 1.759 & 1.437 & 18.3 \\
136.5 & 2.6 & 1.877 & 1.474 & 21.5 \\
137.5 & 1.9 & 1.630 & 1.380 & 15.3 \\
138.5 & 1.7 & 1.880 & 1.614 & 14.1 \\
\hline
\end{tabular}


Table B8. Whole-core susceptibility ( $\kappa$ ) for Lake Litchfield core 1.

\begin{tabular}{|c|c|c|c|c|}
\hline \multirow{2}{*}{ Core-Drive } & Depth in Core & $\begin{array}{l}\text { Corrected Depth } \\
\text { in Core }\end{array}$ & $\kappa$ & Edited $\kappa$ \\
\hline & $(\mathrm{cm})$ & $(\mathrm{cm})$ & $\begin{array}{l}\left(10^{-5} \text { Relative }\right. \\
\text { SI Units) }\end{array}$ & $\begin{array}{c}\left(10^{-5} \text { Relative }\right. \\
\text { SI Units) }\end{array}$ \\
\hline \multirow[t]{38}{*}{ LL-16-C1 } & 0 & - & 4.3 & - \\
\hline & 3 & 3 & 13.6 & 13.6 \\
\hline & 6 & 6 & 16.2 & 16.2 \\
\hline & 9 & 9 & 16.6 & 16.6 \\
\hline & 12 & 12 & 17.5 & 17.5 \\
\hline & 15 & 15 & 13.6 & 13.6 \\
\hline & 18 & 18 & 12.0 & 12.0 \\
\hline & 21 & 21 & 11.4 & 11.4 \\
\hline & 24 & 24 & 11.4 & 11.4 \\
\hline & 27 & 27 & 14.3 & 14.3 \\
\hline & 30 & 30 & 16.0 & 16.0 \\
\hline & 33 & 33 & 16.0 & 16.0 \\
\hline & 36 & 36 & 20.8 & 20.8 \\
\hline & 39 & 39 & 24.5 & 24.5 \\
\hline & 42 & 42 & 18.8 & 18.8 \\
\hline & 45 & 45 & 12.1 & 12.1 \\
\hline & 48 & 48 & 12.5 & 12.5 \\
\hline & 51 & 51 & 15.2 & 15.2 \\
\hline & 54 & 54 & 19.4 & 19.4 \\
\hline & 57 & 57 & 23.4 & 23.4 \\
\hline & 60 & 60 & 17.1 & 17.1 \\
\hline & 63 & 63 & 12.7 & 12.7 \\
\hline & 66 & 66 & 12.0 & 12.0 \\
\hline & 69 & 69 & 14.4 & 14.4 \\
\hline & 72 & 72 & 14.4 & 14.4 \\
\hline & 75 & 75 & 14.7 & 14.7 \\
\hline & 78 & 78 & 25.2 & 25.2 \\
\hline & 81 & 81 & 30.4 & 30.4 \\
\hline & 84 & 84 & 30.0 & 30.0 \\
\hline & 87 & 87 & 29.5 & 29.5 \\
\hline & 90 & 90 & 28.6 & 28.6 \\
\hline & 93 & 93 & 28.4 & 28.4 \\
\hline & 96 & 96 & 31.3 & 31.3 \\
\hline & 99 & 99 & 30.8 & 30.8 \\
\hline & 102 & 102 & 35.7 & 35.7 \\
\hline & 105 & 105 & 40.2 & 40.2 \\
\hline & 108 & 108 & 32.1 & 32.1 \\
\hline & 111 & 111 & 28.4 & 28.4 \\
\hline
\end{tabular}


Table B8. (Cont) Whole-core susceptibility ( $\kappa$ ) for Lake Litchfield core 1.

\begin{tabular}{ccccc}
\hline \hline Core-Drive & Depth in Core & $\begin{array}{c}\text { Corrected Depth } \\
\text { in Core }\end{array}$ & $\kappa$ & Edited $\kappa$ \\
& $(\mathrm{cm})$ & $(\mathrm{cm})$ & $\begin{array}{c}\left(10^{-5} \text { Relative }\right. \\
\text { SI Units })\end{array}$ & $\begin{array}{c}\left(10^{-5} \text { Relative }\right. \\
\text { SI Units })\end{array}$ \\
\hline LL-16-C1 & 114 & 114 & 25.0 & 25.0 \\
& 117 & 117 & 27.2 & 27.2 \\
& 120 & 120 & 33.1 & 33.1 \\
& 123 & 123 & 38.4 & 38.4 \\
& 126 & 126 & 43.4 & 43.4 \\
& 129 & 129 & 44.1 & 44.1 \\
& 132 & 132 & 46.7 & 46.7 \\
& 135 & 135 & 46.4 & 46.4 \\
& 138 & 138 & 42.2 & 42.2 \\
& 141 & - & 23.4 & - \\
\hline
\end{tabular}


Table B9. LOI data for Lake Litchfield core 2.

\begin{tabular}{|c|c|c|c|c|c|}
\hline Core-Drive & $\begin{array}{c}\text { Depth } \\
\text { (cm) }\end{array}$ & $\begin{array}{c}\text { Organic } \\
\text { Matter } \\
(\%)\end{array}$ & $\begin{array}{c}\text { Wet bulk } \\
\text { Density } \\
\left(\mathrm{g} / \mathrm{cm}^{3}\right)\end{array}$ & $\begin{array}{c}\text { Dry Bulk } \\
\text { Density } \\
\left(\mathrm{g} / \mathrm{cm}^{3}\right)\end{array}$ & $\begin{array}{c}\text { Water } \\
\text { Content } \\
(\%)\end{array}$ \\
\hline \multirow[t]{42}{*}{ LL-16-C2 } & 1.5 & 0.5 & 1.658 & 1.361 & 17.9 \\
\hline & 2.5 & 0.5 & 1.739 & 1.404 & 19.3 \\
\hline & 3.5 & 0.5 & 1.651 & 1.345 & 18.5 \\
\hline & 4.5 & 0.4 & 1.553 & 1.251 & 19.4 \\
\hline & 5.5 & 0.8 & 1.632 & 1.327 & 18.7 \\
\hline & 6.5 & 1.0 & 1.553 & 1.241 & 20.1 \\
\hline & 7.5 & 0.9 & 1.739 & 1.384 & 20.4 \\
\hline & 8.5 & 1.7 & 1.641 & 1.297 & 21.0 \\
\hline & 9.5 & 1.7 & 1.669 & 1.317 & 21.1 \\
\hline & 10.5 & 1.5 & 1.658 & 1.370 & 17.4 \\
\hline & 11.5 & 4.7 & 1.338 & 0.913 & 31.8 \\
\hline & 12.5 & 1.1 & 1.588 & 1.303 & 17.9 \\
\hline & 13.5 & 0.8 & 1.448 & 1.184 & 18.2 \\
\hline & 14.5 & 1.0 & 1.607 & 1.298 & 19.2 \\
\hline & 15.5 & 0.8 & 1.729 & 1.390 & 19.6 \\
\hline & 16.5 & 0.5 & 1.680 & 1.350 & 19.6 \\
\hline & 17.5 & 0.5 & 1.764 & 1.433 & 18.8 \\
\hline & 18.5 & 0.4 & 1.687 & 1.374 & 18.6 \\
\hline & 19.5 & 0.9 & 1.698 & 1.386 & 18.4 \\
\hline & 20.5 & 0.8 & 1.601 & 1.325 & 17.2 \\
\hline & 21.5 & 0.9 & 1.526 & 1.265 & 17.1 \\
\hline & 22.5 & 0.9 & 1.314 & 1.121 & 14.7 \\
\hline & 23.5 & 0.7 & 1.699 & 1.379 & 18.8 \\
\hline & 24.5 & 0.8 & 1.700 & 1.369 & 19.5 \\
\hline & 25.5 & 5.1 & 1.003 & 0.730 & 27.2 \\
\hline & 26.5 & 4.4 & 1.357 & 0.960 & 29.3 \\
\hline & 30.5 & 1.1 & 1.644 & 1.331 & 19.0 \\
\hline & 31.5 & 1.4 & 1.577 & 1.255 & 20.4 \\
\hline & 32.5 & 1.9 & 1.516 & 1.241 & 18.1 \\
\hline & 34.5 & 1.5 & 1.549 & 1.257 & 18.9 \\
\hline & 35.5 & 0.8 & 1.526 & 1.251 & 18.0 \\
\hline & 36.5 & 1.0 & 1.610 & 1.306 & 18.9 \\
\hline & 37.5 & 1.3 & 1.544 & 1.254 & 18.8 \\
\hline & 38.5 & 0.5 & 1.660 & 1.341 & 19.2 \\
\hline & 39.5 & 0.7 & 1.676 & 1.356 & 19.1 \\
\hline & 40.5 & 0.8 & 1.630 & 1.316 & 19.3 \\
\hline & 41.5 & 0.8 & 1.641 & 1.317 & 19.7 \\
\hline & 42.5 & 1.4 & 1.653 & 1.328 & 19.7 \\
\hline & 43.5 & 1.5 & 1.678 & 1.371 & 18.3 \\
\hline & 44.5 & 1.3 & 1.596 & 1.272 & 20.3 \\
\hline & 45.5 & 1.1 & 1.639 & 1.311 & 20.0 \\
\hline & 46.5 & 1.1 & 1.653 & 1.335 & 19.2 \\
\hline
\end{tabular}


Table B9. (Cont) LOI data for Lake Litchfield core 2.

\begin{tabular}{|c|c|c|c|c|c|}
\hline Core-Drive & $\begin{array}{c}\text { Depth } \\
\text { (cm) }\end{array}$ & $\begin{array}{c}\text { Organic } \\
\text { Matter } \\
(\%)\end{array}$ & $\begin{array}{c}\text { Wet bulk } \\
\text { Density } \\
\left(\mathrm{g} / \mathrm{cm}^{3}\right)\end{array}$ & $\begin{array}{c}\text { Dry Bulk } \\
\text { Density } \\
\left(\mathrm{g} / \mathrm{cm}^{3}\right)\end{array}$ & $\begin{array}{c}\text { Water } \\
\text { Content } \\
(\%) \\
\end{array}$ \\
\hline \multirow[t]{41}{*}{ LL-16-C2 } & 47.5 & 0.8 & 1.683 & 1.349 & 19.8 \\
\hline & 48.5 & 1.3 & 1.573 & 1.275 & 18.9 \\
\hline & 49.5 & 1.4 & 1.584 & 1.269 & 19.9 \\
\hline & 50.5 & 1.0 & 1.586 & 1.291 & 18.6 \\
\hline & 51.5 & 1.0 & 1.425 & 1.182 & 17.1 \\
\hline & 52.5 & 1.0 & 1.630 & 1.337 & 18.0 \\
\hline & 53.5 & 0.7 & 1.606 & 1.314 & 18.2 \\
\hline & 54.5 & 1.1 & 1.653 & 1.330 & 19.5 \\
\hline & 55.5 & 1.7 & 1.512 & 1.264 & 16.4 \\
\hline & 56.5 & 1.0 & 1.550 & 1.263 & 18.5 \\
\hline & 57.5 & 0.9 & 1.548 & 1.265 & 18.3 \\
\hline & 58.5 & 0.9 & 1.620 & 1.321 & 18.5 \\
\hline & 59.5 & 1.5 & 1.632 & 1.296 & 20.6 \\
\hline & 60.5 & 0.8 & 1.489 & 1.215 & 18.4 \\
\hline & 61.5 & 1.5 & 1.634 & 1.299 & 20.5 \\
\hline & 62.5 & 1.5 & 1.539 & 1.247 & 19.0 \\
\hline & 63.5 & 1.1 & 1.271 & 1.035 & 18.6 \\
\hline & 64.5 & 0.9 & 1.730 & 1.391 & 19.6 \\
\hline & 65.5 & 0.9 & 1.704 & 1.380 & 19.0 \\
\hline & 66.5 & 0.9 & 1.569 & 1.231 & 21.5 \\
\hline & 67.5 & 1.3 & 1.658 & 1.322 & 20.3 \\
\hline & 68.5 & 1.2 & 1.655 & 1.293 & 21.9 \\
\hline & 69.5 & 2.0 & 1.695 & 1.297 & 23.5 \\
\hline & 70.5 & 2.4 & 1.597 & 1.185 & 25.8 \\
\hline & 71.5 & 2.9 & 1.337 & 0.986 & 26.3 \\
\hline & 72.5 & 6.3 & 1.564 & 1.045 & 33.2 \\
\hline & 73.5 & 3.7 & 1.518 & 1.101 & 27.5 \\
\hline & 74.5 & 1.6 & 1.679 & 1.313 & 21.8 \\
\hline & 75.5 & 1.0 & 1.697 & 1.364 & 19.6 \\
\hline & 76.5 & 1.3 & 1.577 & 1.271 & 19.4 \\
\hline & 77.5 & 0.9 & 1.667 & 1.338 & 19.7 \\
\hline & 78.5 & 1.1 & 1.771 & 1.392 & 21.4 \\
\hline & 80.5 & 1.5 & 1.287 & 1.015 & 21.1 \\
\hline & 81.5 & 1.5 & 1.707 & 1.372 & 19.6 \\
\hline & 82.5 & 1.9 & 1.513 & 1.220 & 19.4 \\
\hline & 83.5 & 1.9 & 1.510 & 1.233 & 18.3 \\
\hline & 84.5 & 2.0 & 1.614 & 1.288 & 20.2 \\
\hline & 85.5 & 1.8 & 1.332 & 1.089 & 18.2 \\
\hline & 86.5 & 1.8 & 1.298 & 1.074 & 17.3 \\
\hline & 87.5 & 1.9 & 1.538 & 1.223 & 20.5 \\
\hline & 88.5 & 1.9 & 1.511 & 1.271 & 15.9 \\
\hline
\end{tabular}


Table B10. Whole-core susceptibility ( $\kappa$ ) for Lake Litchfield core 2.

\begin{tabular}{|c|c|c|c|c|}
\hline \multirow{2}{*}{ Core-Drive } & $\begin{array}{l}\text { Depth in } \\
\text { Core }\end{array}$ & $\begin{array}{c}\text { Corrected } \\
\text { Depth in Core }\end{array}$ & $\kappa$ & Edited $\kappa$ \\
\hline & $(\mathrm{cm})$ & $(\mathrm{cm})$ & $\begin{array}{l}\text { (10 }{ }^{-5} \text { Relative } \\
\text { SI Units) }\end{array}$ & $\begin{array}{c}\text { (10 }{ }^{-5} \text { Relative } \\
\text { SI Units) }\end{array}$ \\
\hline \multirow[t]{32}{*}{ LL-16-C2 } & 0 & - & 4.0 & - \\
\hline & 3 & 3 & 23.2 & 23.2 \\
\hline & 6 & 6 & 27.0 & 27.0 \\
\hline & 9 & 9 & 14.4 & 14.4 \\
\hline & 12 & 12 & 14.7 & 14.7 \\
\hline & 15 & 15 & 20.7 & 20.7 \\
\hline & 18 & 18 & 42.3 & 42.3 \\
\hline & 21 & 21 & 40.6 & 40.6 \\
\hline & 24 & 24 & 26.0 & 26.0 \\
\hline & 27 & 27 & 16.7 & 16.7 \\
\hline & 30 & 30 & 10.7 & 10.7 \\
\hline & 33 & 33 & 12.3 & 12.3 \\
\hline & 36 & 36 & 11.9 & 11.9 \\
\hline & 39 & 39 & 9.2 & 9.2 \\
\hline & 42 & 42 & 8.1 & 8.1 \\
\hline & 45 & 45 & 9.0 & 9.0 \\
\hline & 48 & 48 & 10.3 & 10.3 \\
\hline & 51 & 51 & 11.9 & 11.9 \\
\hline & 54 & 54 & 16.8 & 16.8 \\
\hline & 57 & 57 & 13.4 & 13.4 \\
\hline & 60 & 60 & 12.5 & 12.5 \\
\hline & 63 & 63 & 11.8 & 11.8 \\
\hline & 66 & 66 & 12.7 & 12.7 \\
\hline & 69 & 69 & 12.2 & 12.2 \\
\hline & 72 & 72 & 11.9 & 11.9 \\
\hline & 75 & 75 & 9.4 & 9.4 \\
\hline & 78 & 78 & 10.3 & 10.3 \\
\hline & 81 & 81 & 10.6 & 10.6 \\
\hline & 84 & 84 & 13.7 & 13.7 \\
\hline & 87 & 87 & 13.8 & 13.8 \\
\hline & 90 & 90 & 9.0 & 9.0 \\
\hline & 93 & - & 1.5 & - \\
\hline
\end{tabular}


Table B11. LOI data for Lake Litchfield core 3.

\begin{tabular}{|c|c|c|c|c|c|}
\hline Core-Drive & $\begin{array}{l}\text { Depth } \\
(\mathrm{cm})\end{array}$ & $\begin{array}{c}\text { Organic } \\
\text { Matter } \\
(\%)\end{array}$ & $\begin{array}{c}\text { Wet bulk } \\
\text { Density } \\
\left(\mathrm{g} / \mathrm{cm}^{3}\right)\end{array}$ & $\begin{array}{c}\text { Dry Bulk } \\
\text { Density } \\
\left(\mathrm{g} / \mathrm{cm}^{3}\right)\end{array}$ & $\begin{array}{c}\text { Water } \\
(\%)\end{array}$ \\
\hline \multirow[t]{40}{*}{ LL-16-C3 } & 0.5 & 1.0 & 1.730 & 1.371 & 20.8 \\
\hline & 1.5 & 0.9 & 1.677 & 1.370 & 18.3 \\
\hline & 2.5 & 1.3 & 1.631 & 1.337 & 18.0 \\
\hline & 3.5 & 1.0 & 1.678 & 1.329 & 20.8 \\
\hline & 4.5 & 1.0 & 1.635 & 1.291 & 21.0 \\
\hline & 5.5 & 1.2 & 1.634 & 1.288 & 21.2 \\
\hline & 6.5 & 0.9 & 1.617 & 1.270 & 21.5 \\
\hline & 7.5 & 0.7 & 1.721 & 1.362 & 20.9 \\
\hline & 8.5 & 0.5 & 1.669 & 1.333 & 20.1 \\
\hline & 9.5 & 0.5 & 1.811 & 1.441 & 20.4 \\
\hline & 10.5 & 0.5 & 1.587 & 1.276 & 19.6 \\
\hline & 11.5 & 0.7 & 1.699 & 1.364 & 19.7 \\
\hline & 12.5 & 0.6 & 1.634 & 1.326 & 18.8 \\
\hline & 13.5 & 0.7 & 1.418 & 1.171 & 17.4 \\
\hline & 14.5 & 0.9 & 1.637 & 1.349 & 17.6 \\
\hline & 15.5 & 0.9 & 1.560 & 1.291 & 17.2 \\
\hline & 16.5 & 1.1 & 1.590 & 1.307 & 17.8 \\
\hline & 17.5 & 0.7 & 1.594 & 1.297 & 18.6 \\
\hline & 18.5 & 1.2 & 1.432 & 1.230 & 14.1 \\
\hline & 19.5 & 0.9 & 1.514 & 1.271 & 16.1 \\
\hline & 20.5 & 0.7 & 1.535 & 1.269 & 17.3 \\
\hline & 21.5 & 0.9 & 1.655 & 1.362 & 17.7 \\
\hline & 22.5 & 1.1 & 1.487 & 1.233 & 17.1 \\
\hline & 23.5 & 0.9 & 1.698 & 1.386 & 18.4 \\
\hline & 24.5 & 0.7 & 1.641 & 1.322 & 19.4 \\
\hline & 25.5 & 1.5 & 1.722 & 1.346 & 21.8 \\
\hline & 27.5 & 0.5 & 1.721 & 1.367 & 20.6 \\
\hline & 28.5 & 0.7 & 1.688 & 1.342 & 20.5 \\
\hline & 29.5 & 0.5 & 1.819 & 1.446 & 20.5 \\
\hline & 30.5 & 0.4 & 1.757 & 1.405 & 20.0 \\
\hline & 31.5 & 0.5 & 1.640 & 1.307 & 20.3 \\
\hline & 32.5 & 0.5 & 1.539 & 1.262 & 18.0 \\
\hline & 33.5 & 0.4 & 1.669 & 1.337 & 19.9 \\
\hline & 34.5 & 0.5 & 1.726 & 1.390 & 19.5 \\
\hline & 35.5 & 0.6 & 1.768 & 1.428 & 19.2 \\
\hline & 36.5 & 0.6 & 1.784 & 1.441 & 19.2 \\
\hline & 37.5 & 0.7 & 1.672 & 1.355 & 19.0 \\
\hline & 38.5 & 2.0 & 1.420 & 1.092 & 23.1 \\
\hline & 39.5 & 1.7 & 1.588 & 1.261 & 20.6 \\
\hline & 40.5 & 2.7 & 1.494 & 1.150 & 23.0 \\
\hline
\end{tabular}


Table B11. (Cont) LOI data for Lake Litchfield core 3.

\begin{tabular}{cccccc}
\hline \hline \multirow{2}{*}{ Core-Drive } & $\begin{array}{c}\text { Depth } \\
(\mathrm{cm})\end{array}$ & $\begin{array}{c}\text { Organic } \\
\text { Matter } \\
(\%)\end{array}$ & $\begin{array}{c}\text { Wet bulk } \\
\text { Density } \\
\left(\mathrm{g} / \mathrm{cm}^{3}\right)\end{array}$ & $\begin{array}{c}\text { Dry Bulk } \\
\text { Density } \\
\left(\mathrm{g} / \mathrm{cm}^{3}\right)\end{array}$ & $\begin{array}{c}\text { Water } \\
(\%)\end{array}$ \\
\hline LL-16-C3 & 42.5 & 0.7 & 1.635 & 1.338 & 18.2 \\
& 43.5 & 0.8 & 1.448 & 1.198 & 17.3 \\
& 44.5 & 0.9 & 1.597 & 1.339 & 16.2 \\
& 45.5 & 0.8 & 1.471 & 1.198 & 18.6 \\
& 46.5 & 0.8 & 1.731 & 1.390 & 19.7 \\
47.5 & 0.9 & 1.670 & 1.315 & 21.3 \\
& 48.5 & 0.8 & 1.662 & 1.324 & 20.3 \\
49.5 & 0.6 & 1.787 & 1.432 & 19.9 \\
50.5 & 0.7 & 1.698 & 1.360 & 19.9 \\
51.5 & 0.6 & 1.763 & 1.413 & 19.9 \\
52.5 & 0.4 & 1.714 & 1.365 & 20.4 \\
53.5 & 0.4 & 1.763 & 1.418 & 19.6 \\
54.5 & 0.6 & 1.748 & 1.427 & 18.4 \\
55.5 & 0.7 & 1.660 & 1.348 & 18.8 \\
56.5 & 1.4 & 1.678 & 1.358 & 19.1 \\
58.5 & 4.0 & 1.519 & 1.160 & 23.6 \\
\hline
\end{tabular}




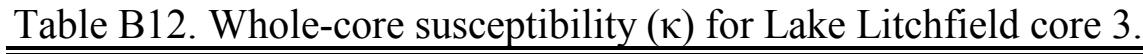

\begin{tabular}{|c|c|c|c|c|}
\hline Core-Drive & $\begin{array}{l}\text { Depth in } \\
\text { Core } \\
\text { (cm) }\end{array}$ & $\begin{array}{c}\text { Corrected } \\
\text { Depth in Core } \\
\text { (cm) }\end{array}$ & $\begin{array}{c}\kappa \\
\left(10^{-5} \text { Relative }\right. \\
\text { SI Units })\end{array}$ & $\begin{array}{c}\text { Edited } \kappa \\
\left(10^{-5} \text { Relative }\right. \\
\text { SI Units })\end{array}$ \\
\hline \multirow[t]{20}{*}{ LL-16-C3 } & 3 & - & 10.7 & - \\
\hline & 6 & 6 & 9.4 & 9.4 \\
\hline & 9 & 9 & 8.3 & 8.3 \\
\hline & 12 & 12 & 7.9 & 7.9 \\
\hline & 15 & 15 & 10.5 & 10.5 \\
\hline & 18 & 18 & 12.2 & 12.2 \\
\hline & 21 & 21 & 13.4 & 13.4 \\
\hline & 24 & 24 & 13.6 & 13.6 \\
\hline & 27 & 27 & 14.5 & 14.5 \\
\hline & 30 & 30 & 13.4 & 13.4 \\
\hline & 33 & 33 & 12.6 & 12.6 \\
\hline & 36 & 36 & 10.3 & 10.3 \\
\hline & 39 & 39 & 11.8 & 11.8 \\
\hline & 42 & 42 & 13.9 & 13.9 \\
\hline & 45 & 45 & 14.3 & 14.3 \\
\hline & 48 & 48 & 15.3 & 15.3 \\
\hline & 51 & 51 & 13.9 & 13.9 \\
\hline & 54 & 54 & 13.2 & 13.2 \\
\hline & 57 & 57 & 10.8 & 10.8 \\
\hline & 60 & - & 3.9 & - \\
\hline
\end{tabular}


Table B13. LOI data for Old Mill Pond core 2.

\begin{tabular}{|c|c|c|c|c|c|}
\hline Core-Drive & $\begin{array}{l}\text { Depth } \\
(\mathrm{cm})\end{array}$ & $\begin{array}{c}\text { Organic } \\
\text { Matter } \\
(\%) \\
\end{array}$ & $\begin{array}{c}\text { Wet bulk } \\
\text { Density } \\
\left(\mathrm{g} / \mathrm{cm}^{3}\right) \\
\end{array}$ & $\begin{array}{c}\text { Dry Bulk } \\
\text { Density } \\
\left(\mathrm{g} / \mathrm{cm}^{3}\right) \\
\end{array}$ & $\begin{array}{c}\text { Water } \\
\text { Content } \\
(\%) \\
\end{array}$ \\
\hline \multirow[t]{40}{*}{ OMP-16-C2 } & 0.5 & 9.4 & 1.328 & 0.608 & 54.2 \\
\hline & 1.5 & 9.6 & 1.179 & 0.542 & 54.0 \\
\hline & 2.5 & 9.7 & 1.319 & 0.589 & 55.3 \\
\hline & 3.5 & 9.5 & 1.283 & 0.582 & 54.6 \\
\hline & 4.5 & 9.5 & 1.326 & 0.602 & 54.6 \\
\hline & 5.5 & 9.8 & 1.310 & 0.589 & 55.0 \\
\hline & 6.5 & 9.7 & 1.275 & 0.579 & 54.6 \\
\hline & 7.5 & 9.7 & 1.275 & 0.579 & 54.6 \\
\hline & 8.5 & 10.0 & 1.374 & 0.638 & 53.6 \\
\hline & 9.5 & 9.2 & 1.391 & 0.642 & 53.8 \\
\hline & 10.5 & 8.9 & 1.319 & 0.629 & 52.3 \\
\hline & 11.5 & 8.7 & 1.399 & 0.681 & 51.3 \\
\hline & 12.5 & 8.5 & 1.433 & 0.715 & 50.1 \\
\hline & 13.5 & 8.5 & 1.450 & 0.71 & 51.0 \\
\hline & 14.5 & 8.4 & 1.391 & 0.694 & 50.1 \\
\hline & 15.5 & 8.4 & 1.428 & 0.711 & 50.2 \\
\hline & 16.5 & 8.3 & 1.352 & 0.678 & 49.9 \\
\hline & 17.5 & 8.2 & 1.147 & 0.571 & 50.2 \\
\hline & 18.5 & 7.8 & 1.459 & 0.755 & 48.3 \\
\hline & 19.5 & 7.7 & 1.449 & 0.763 & 47.3 \\
\hline & 20.5 & 7.7 & 1.336 & 0.692 & 48.2 \\
\hline & 21.5 & 7.2 & 1.464 & 0.801 & 45.3 \\
\hline & 22.5 & 6.9 & 1.360 & 0.734 & 46.0 \\
\hline & 23.5 & 6.8 & 1.360 & 0.734 & 46.0 \\
\hline & 24.5 & 7.0 & 1.372 & 0.741 & 46.0 \\
\hline & 25.5 & 6.8 & 1.504 & 0.822 & 45.3 \\
\hline & 26.5 & 6.7 & 1.495 & 0.809 & 45.9 \\
\hline & 27.5 & 6.5 & 1.447 & 0.794 & 45.1 \\
\hline & 28.5 & 6.6 & 1.484 & 0.819 & 44.8 \\
\hline & 29.5 & 6.5 & 1.478 & 0.816 & 44.8 \\
\hline & 30.5 & 6.6 & 1.490 & 0.816 & 45.2 \\
\hline & 31.5 & 6.6 & 1.485 & 0.807 & 45.7 \\
\hline & 32.5 & 6.6 & 1.462 & 0.805 & 44.9 \\
\hline & 33.5 & 6.7 & 1.482 & 0.819 & 44.7 \\
\hline & 34.5 & 7.1 & 1.460 & 0.82 & 43.8 \\
\hline & 35.5 & 7.2 & 1.471 & 0.822 & 44.1 \\
\hline & 36.5 & 7.4 & 1.459 & 0.802 & 45.0 \\
\hline & 37.5 & 7.2 & 1.572 & 0.873 & 44.5 \\
\hline & 38.5 & 7.4 & 1.461 & 0.794 & 45.7 \\
\hline & 39.5 & 7.5 & 1.428 & 0.786 & 45.0 \\
\hline
\end{tabular}


Table B13. (Cont) LOI data for Old Mill Pond core 2.

\begin{tabular}{|c|c|c|c|c|c|}
\hline Core-Drive & $\begin{array}{l}\text { Depth } \\
(\mathrm{cm})\end{array}$ & $\begin{array}{c}\text { Organic } \\
\text { Matter } \\
(\%)\end{array}$ & $\begin{array}{c}\text { Wet bulk } \\
\text { Density } \\
\left(\mathrm{g} / \mathrm{cm}^{3}\right)\end{array}$ & $\begin{array}{c}\text { Dry Bulk } \\
\text { Density } \\
\left(\mathrm{g} / \mathrm{cm}^{3}\right)\end{array}$ & $\begin{array}{c}\text { Water } \\
\text { Content } \\
(\%)\end{array}$ \\
\hline \multirow[t]{39}{*}{ OMP-16-C2 } & 40.5 & 7.5 & 1.417 & 0.762 & 46.2 \\
\hline & 41.5 & 7.2 & 1.404 & 0.763 & 45.7 \\
\hline & 42.5 & 7.0 & 1.476 & 0.810 & 45.1 \\
\hline & 43.5 & 7.0 & 1.504 & 0.825 & 45.1 \\
\hline & 44.5 & 7.0 & 1.465 & 0.817 & 44.2 \\
\hline & 45.5 & 7.2 & 1.388 & 0.777 & 44.0 \\
\hline & 46.5 & 7.0 & 1.458 & 0.818 & 43.9 \\
\hline & 47.5 & 6.9 & 1.508 & 0.837 & 44.5 \\
\hline & 48.5 & 6.8 & 1.479 & 0.847 & 42.7 \\
\hline & 49.5 & 6.8 & 1.502 & 0.840 & 44.1 \\
\hline & 50.5 & 6.3 & 1.442 & 0.811 & 43.8 \\
\hline & 51.5 & 6.2 & 1.497 & 0.833 & 44.4 \\
\hline & 52.5 & 6.3 & 1.487 & 0.828 & 44.3 \\
\hline & 53.5 & 6.5 & 1.446 & 0.801 & 44.6 \\
\hline & 54.5 & 6.2 & 1.484 & 0.801 & 46.0 \\
\hline & 55.5 & 6.4 & 1.469 & 0.807 & 45.1 \\
\hline & 56.5 & 6.5 & 1.492 & 0.834 & 44.1 \\
\hline & 57.5 & 6.6 & 1.465 & 0.808 & 44.8 \\
\hline & 58.5 & 6.5 & 1.509 & 0.827 & 45.2 \\
\hline & 59.5 & 7.1 & 1.471 & 0.786 & 46.6 \\
\hline & 60.5 & 7.1 & 1.415 & 0.757 & 46.5 \\
\hline & 61.5 & 7.5 & 1.374 & 0.711 & 48.3 \\
\hline & 62.5 & 7.1 & 1.464 & 0.765 & 47.7 \\
\hline & 63.5 & 7.0 & 1.419 & 0.752 & 47.0 \\
\hline & 64.5 & 6.8 & 1.465 & 0.805 & 45.1 \\
\hline & 65.5 & 6.7 & 1.495 & 0.836 & 44.1 \\
\hline & 66.5 & 6.8 & 1.476 & 0.823 & 44.2 \\
\hline & 67.5 & 7.1 & 1.507 & 0.850 & 43.6 \\
\hline & 68.5 & 7.1 & 1.445 & 0.773 & 46.5 \\
\hline & 69.5 & 6.9 & 1.500 & 0.826 & 44.9 \\
\hline & 70.5 & 7.1 & 1.469 & 0.818 & 44.3 \\
\hline & 71.5 & 7.4 & 1.474 & 0.815 & 44.7 \\
\hline & 72.5 & 7.5 & 1.402 & 0.761 & 45.7 \\
\hline & 73.5 & 7.3 & 1.489 & 0.832 & 44.1 \\
\hline & 74.5 & 7.4 & 1.491 & 0.848 & 43.1 \\
\hline & 75.5 & 7.1 & 1.540 & 0.868 & 43.6 \\
\hline & 76.5 & 7.7 & 1.474 & 0.822 & 44.2 \\
\hline & 77.5 & 7.4 & 1.492 & 0.837 & 43.9 \\
\hline & 78.5 & 7.7 & 1.432 & 0.797 & 44.3 \\
\hline
\end{tabular}


Table B13. (Cont) LOI data for Old Mill Pond core 2.

\begin{tabular}{|c|c|c|c|c|c|}
\hline Core-Drive & $\begin{array}{l}\text { Depth } \\
(\mathrm{cm})\end{array}$ & $\begin{array}{c}\text { Organic } \\
\text { Matter } \\
(\%)\end{array}$ & $\begin{array}{c}\text { Wet bulk } \\
\text { Density } \\
\left(\mathrm{g} / \mathrm{cm}^{3}\right)\end{array}$ & $\begin{array}{c}\text { Dry Bulk } \\
\text { Density } \\
\left(\mathrm{g} / \mathrm{cm}^{3}\right)\end{array}$ & $\begin{array}{c}\text { Water } \\
\text { Content } \\
(\%)\end{array}$ \\
\hline \multirow[t]{39}{*}{ OMP-16-C2 } & 79.5 & 8.4 & 1.413 & 0.758 & 46.4 \\
\hline & 80.5 & 8.4 & 1.515 & 0.836 & 44.8 \\
\hline & 81.5 & 8.5 & 1.406 & 0.703 & 50.0 \\
\hline & 82.5 & 8.6 & 1.400 & 0.709 & 49.4 \\
\hline & 83.5 & 8.6 & 1.455 & 0.759 & 47.8 \\
\hline & 84.5 & 8.7 & 1.438 & 0.767 & 46.7 \\
\hline & 85.5 & 8.8 & 1.440 & 0.770 & 46.5 \\
\hline & 86.5 & 8.6 & 1.448 & 0.778 & 46.3 \\
\hline & 87.5 & 8.5 & 1.474 & 0.764 & 48.2 \\
\hline & 88.5 & 8.7 & 1.464 & 0.805 & 45.0 \\
\hline & 89.5 & 8.8 & 1.447 & 0.800 & 44.7 \\
\hline & 90.5 & 8.6 & 1.452 & 0.777 & 46.5 \\
\hline & 91.5 & 9.0 & 1.429 & 0.776 & 45.7 \\
\hline & 92.5 & 8.9 & 1.371 & 0.732 & 46.6 \\
\hline & 93.5 & 8.5 & 1.373 & 0.719 & 47.6 \\
\hline & 94.5 & 8.1 & 1.459 & 0.787 & 46.1 \\
\hline & 95.5 & 8.3 & 1.310 & 0.662 & 49.5 \\
\hline & 96.5 & 7.7 & 1.326 & 0.691 & 47.9 \\
\hline & 97.5 & 7.3 & 1.340 & 0.735 & 45.1 \\
\hline & 98.5 & 6.9 & 1.378 & 0.795 & 42.3 \\
\hline & 99.5 & 7.3 & 1.445 & 0.813 & 43.7 \\
\hline & 100.5 & 7.5 & 1.408 & 0.776 & 44.9 \\
\hline & 101.5 & 7.3 & 1.453 & 0.827 & 43.1 \\
\hline & 102.5 & 8.0 & 1.442 & 0.766 & 46.9 \\
\hline & 103.5 & 8.0 & 1.457 & 0.776 & 46.7 \\
\hline & 104.5 & 7.8 & 1.462 & 0.793 & 45.8 \\
\hline & 105.5 & 8.7 & 1.394 & 0.713 & 48.9 \\
\hline & 106.5 & 9.1 & 1.342 & 0.661 & 50.7 \\
\hline & 107.5 & 8.6 & 1.393 & 0.701 & 49.7 \\
\hline & 108.5 & 8.6 & 1.400 & 0.689 & 50.8 \\
\hline & 109.5 & 9.3 & 1.357 & 0.605 & 55.4 \\
\hline & 110.5 & 9.5 & 1.311 & 0.570 & 56.5 \\
\hline & 111.5 & 9.3 & 1.358 & 0.624 & 54.1 \\
\hline & 112.5 & 8.9 & 1.341 & 0.638 & 52.4 \\
\hline & 113.5 & 9.1 & 1.350 & 0.637 & 52.8 \\
\hline & 114.5 & 8.1 & 1.396 & 0.695 & 50.2 \\
\hline & 115.5 & 7.6 & 1.409 & 0.719 & 49.0 \\
\hline & 116.5 & 7.2 & 1.459 & 0.789 & 45.9 \\
\hline & 117.5 & 7.0 & 1.498 & 0.854 & 43.0 \\
\hline
\end{tabular}


Table B13. (Cont) LOI data for Old Mill Pond core 2.

\begin{tabular}{|c|c|c|c|c|c|}
\hline Core-Drive & $\begin{array}{l}\text { Depth } \\
(\mathrm{cm})\end{array}$ & $\begin{array}{c}\text { Organic } \\
\text { Matter } \\
(\%)\end{array}$ & $\begin{array}{c}\text { Wet bulk } \\
\text { Density } \\
\left(\mathrm{g} / \mathrm{cm}^{3}\right)\end{array}$ & $\begin{array}{c}\text { Dry Bulk } \\
\text { Density } \\
\left(\mathrm{g} / \mathrm{cm}^{3}\right)\end{array}$ & $\begin{array}{c}\text { Water } \\
\text { Content } \\
\text { (\%) }\end{array}$ \\
\hline \multirow[t]{36}{*}{ OMP-16-C2 } & 118.5 & 7.2 & 1.512 & 0.857 & 43.3 \\
\hline & 119.5 & 7.3 & 1.374 & 0.737 & 46.4 \\
\hline & 120.5 & 7.0 & 1.441 & 0.814 & 43.5 \\
\hline & 121.5 & 7.0 & 1.476 & 0.823 & 44.2 \\
\hline & 122.5 & 7.1 & 1.414 & 0.775 & 45.2 \\
\hline & 123.5 & 7.2 & 1.449 & 0.808 & 44.2 \\
\hline & 124.5 & 5.5 & 1.566 & 0.965 & 38.4 \\
\hline & 125.5 & 9.9 & 1.351 & 0.604 & 55.3 \\
\hline & 126.5 & 11.0 & 1.244 & 0.489 & 60.7 \\
\hline & 127.5 & 11.0 & 1.200 & 0.428 & 64.3 \\
\hline & 128.5 & 10.7 & 1.243 & 0.542 & 56.4 \\
\hline & 129.5 & 11.5 & 1.276 & 0.480 & 62.4 \\
\hline & 130.5 & 11.5 & 1.270 & 0.495 & 61.0 \\
\hline & 131.5 & 10.0 & 1.427 & 0.697 & 51.2 \\
\hline & 132.5 & 10.4 & 1.358 & 0.628 & 53.8 \\
\hline & 133.5 & 10.6 & 1.374 & 0.624 & 54.6 \\
\hline & 134.5 & 10.2 & 1.386 & 0.650 & 53.1 \\
\hline & 135.5 & 10.2 & 1.380 & 0.659 & 52.2 \\
\hline & 136.5 & 10.6 & 1.351 & 0.625 & 53.7 \\
\hline & 137.5 & 9.8 & 1.350 & 0.625 & 53.7 \\
\hline & 138.5 & 10.2 & 1.311 & 0.615 & 53.1 \\
\hline & 139.5 & 9.5 & 1.337 & 0.623 & 53.4 \\
\hline & 140.5 & 8.2 & 1.365 & 0.670 & 50.9 \\
\hline & 141.5 & 6.1 & 1.545 & 0.977 & 36.8 \\
\hline & 142.5 & 9.4 & 1.343 & 0.631 & 53.0 \\
\hline & 143.5 & 9.0 & 1.514 & 0.862 & 43.1 \\
\hline & 144.5 & 10.8 & 1.320 & 0.713 & 46.0 \\
\hline & 145.5 & 8.7 & 1.477 & 0.855 & 42.1 \\
\hline & 146.5 & 9.9 & 1.367 & 0.694 & 49.2 \\
\hline & 147.5 & 10.1 & 1.308 & 0.631 & 51.8 \\
\hline & 148.5 & 9.8 & 1.387 & 0.660 & 52.4 \\
\hline & 149.5 & 11.3 & 1.471 & 0.787 & 46.5 \\
\hline & 150.5 & 9.1 & 1.584 & 1.040 & 34.3 \\
\hline & 151.5 & 8.4 & 1.672 & 1.125 & 32.7 \\
\hline & 152.5 & 12.0 & 1.511 & 0.886 & 41.4 \\
\hline & 153.5 & 11.4 & 1.496 & 0.878 & 41.3 \\
\hline
\end{tabular}


Table B14. Whole-core susceptibility ( $\kappa$ ) for Old Mill Pond core 2.

\begin{tabular}{|c|c|c|c|c|}
\hline Core-Drive & $\begin{array}{l}\text { Depth in } \\
\text { Core } \\
\text { (cm) }\end{array}$ & $\begin{array}{c}\text { Corrected } \\
\text { Depth in Core } \\
\text { (cm) }\end{array}$ & $\begin{array}{c}\kappa \\
\left(10^{-5} \text { Relative }\right. \\
\text { SI Units })\end{array}$ & $\begin{array}{c}\text { Edited } \kappa \\
\left(10^{-5} \text { Relative }\right. \\
\text { SI Units })\end{array}$ \\
\hline \multirow[t]{39}{*}{ OMP-16-C2 } & 0 & - & 8.7 & - \\
\hline & 3 & 3 & 13.3 & 13.3 \\
\hline & 6 & 6 & 15.1 & 15.1 \\
\hline & 9 & 9 & 16.7 & 16.7 \\
\hline & 12 & 12 & 18.0 & 18.0 \\
\hline & 15 & 15 & 18.4 & 18.4 \\
\hline & 18 & 18 & 18.5 & 18.5 \\
\hline & 21 & 21 & 18.4 & 18.4 \\
\hline & 24 & 24 & 18.6 & 18.6 \\
\hline & 27 & 27 & 18.7 & 18.7 \\
\hline & 30 & 30 & 18.8 & 18.8 \\
\hline & 33 & 33 & 20.1 & 20.1 \\
\hline & 36 & 36 & 21.5 & 21.5 \\
\hline & 39 & 39 & 21.6 & 21.6 \\
\hline & 42 & 42 & 21.4 & 21.4 \\
\hline & 45 & 45 & 20.2 & 20.2 \\
\hline & 48 & 48 & 21.4 & 21.4 \\
\hline & 51 & 51 & 18.7 & 18.7 \\
\hline & 54 & 54 & 19.1 & 19.1 \\
\hline & 57 & 57 & 17.1 & 17.1 \\
\hline & 60 & 60 & 16.9 & 16.9 \\
\hline & 63 & 63 & 17.9 & 17.9 \\
\hline & 66 & 66 & 18.7 & 18.7 \\
\hline & 69 & 69 & 19.3 & 19.3 \\
\hline & 72 & 72 & 20.4 & 20.4 \\
\hline & 75 & 75 & 21.1 & 21.1 \\
\hline & 78 & 78 & 21.9 & 21.9 \\
\hline & 81 & 81 & 23.0 & 23.0 \\
\hline & 84 & 84 & 23.8 & 23.8 \\
\hline & 87 & 87 & 24.7 & 24.7 \\
\hline & 90 & 90 & 25.7 & 25.7 \\
\hline & 93 & 93 & 22.8 & 22.8 \\
\hline & 96 & 96 & 21.3 & 21.3 \\
\hline & 99 & 99 & 22.1 & 22.1 \\
\hline & 102 & 102 & 22.9 & 22.9 \\
\hline & 105 & 105 & 22.1 & 22.1 \\
\hline & 108 & 108 & 19.5 & 19.5 \\
\hline & 111 & 111 & 18.0 & 18.0 \\
\hline & 114 & 114 & 18.7 & 18.7 \\
\hline
\end{tabular}


Table B15. LOI data for Old Mill Pond core 3.

\begin{tabular}{|c|c|c|c|c|c|}
\hline Core-Drive & $\begin{array}{c}\text { Depth } \\
\text { (cm) }\end{array}$ & $\begin{array}{c}\text { Organic } \\
\text { Matter } \\
(\%)\end{array}$ & $\begin{array}{c}\text { Wet bulk } \\
\text { Density } \\
\left(\mathrm{g} / \mathrm{cm}^{3}\right)\end{array}$ & $\begin{array}{c}\text { Dry Bulk } \\
\text { Density } \\
\left(\mathrm{g} / \mathrm{cm}^{3}\right)\end{array}$ & $\begin{array}{c}\text { Water } \\
\text { Content } \\
(\%)\end{array}$ \\
\hline \multirow[t]{40}{*}{ OMP-16-C3 } & 0.5 & 10.5 & 1.211 & 0.516 & 57.4 \\
\hline & 1.5 & 10.0 & 1.274 & 0.542 & 57.5 \\
\hline & 2.5 & 10.0 & 1.133 & 0.482 & 57.5 \\
\hline & 3.5 & 9.9 & 1.116 & 0.474 & 57.5 \\
\hline & 4.5 & 8.3 & 1.368 & 0.396 & 71.1 \\
\hline & 5.5 & 9.6 & 1.152 & 0.501 & 56.5 \\
\hline & 6.5 & 9.5 & 1.096 & 0.483 & 55.9 \\
\hline & 7.5 & 10.0 & 1.252 & 0.568 & 54.6 \\
\hline & 8.5 & 9.7 & 1.354 & 0.620 & 54.2 \\
\hline & 9.5 & 9.3 & 1.332 & 0.616 & 53.8 \\
\hline & 10.5 & 9.1 & 0.949 & 0.453 & 52.3 \\
\hline & 11.5 & 9.2 & 1.257 & 0.597 & 52.5 \\
\hline & 12.5 & 8.9 & 1.268 & 0.621 & 51.0 \\
\hline & 13.5 & 8.8 & 1.388 & 0.678 & 51.2 \\
\hline & 14.5 & 8.7 & 1.309 & 0.663 & 49.4 \\
\hline & 15.5 & 8.5 & 1.309 & 0.662 & 49.4 \\
\hline & 16.5 & 8.3 & 1.205 & 0.618 & 48.7 \\
\hline & 17.5 & 8.2 & 1.348 & 0.685 & 49.2 \\
\hline & 18.5 & 8.3 & 1.390 & 0.715 & 48.6 \\
\hline & 19.5 & 7.9 & 1.316 & 0.695 & 47.2 \\
\hline & 20.5 & 7.8 & 1.413 & 0.756 & 46.5 \\
\hline & 21.5 & 7.6 & 1.281 & 0.675 & 47.3 \\
\hline & 22.5 & 7.5 & 1.077 & 0.574 & 46.7 \\
\hline & 23.5 & 7.3 & 1.223 & 0.659 & 46.1 \\
\hline & 24.5 & 7.2 & 1.385 & 0.734 & 47.0 \\
\hline & 25.5 & 7.2 & 1.260 & 0.681 & 46.0 \\
\hline & 26.5 & 7.4 & 1.175 & 0.653 & 44.4 \\
\hline & 27.5 & 7.3 & 1.467 & 0.818 & 44.2 \\
\hline & 28.5 & 7.3 & 1.369 & 0.753 & 45.0 \\
\hline & 29.5 & 7.2 & 1.392 & 0.769 & 44.8 \\
\hline & 30.5 & 6.9 & 1.380 & 0.765 & 44.6 \\
\hline & 31.5 & 6.8 & 1.428 & 0.803 & 43.8 \\
\hline & 32.5 & 7.3 & 1.382 & 0.767 & 44.5 \\
\hline & 33.5 & 7.3 & 1.457 & 0.822 & 43.6 \\
\hline & 34.5 & 7.5 & 1.432 & 0.796 & 44.4 \\
\hline & 35.5 & 7.9 & 1.371 & 0.747 & 45.5 \\
\hline & 36.5 & 8.0 & 1.480 & 0.822 & 44.5 \\
\hline & 37.5 & 7.9 & 1.406 & 0.761 & 45.9 \\
\hline & 38.5 & 7.8 & 1.453 & 0.799 & 45.0 \\
\hline & 39.5 & 7.5 & 1.434 & 0.795 & 44.6 \\
\hline
\end{tabular}


Table B15. (Cont) LOI data for Old Mill Pond core 3.

\begin{tabular}{|c|c|c|c|c|c|}
\hline Core-Drive & $\begin{array}{l}\text { Depth } \\
(\mathrm{cm}) \\
\end{array}$ & $\begin{array}{c}\text { Organic } \\
\text { Matter } \\
(\%) \\
\end{array}$ & $\begin{array}{c}\text { Wet bulk } \\
\text { Density } \\
\left(\mathrm{g} / \mathrm{cm}^{3}\right) \\
\end{array}$ & $\begin{array}{c}\text { Dry Bulk } \\
\text { Density } \\
\left(\mathrm{g} / \mathrm{cm}^{3}\right) \\
\end{array}$ & $\begin{array}{c}\text { Water } \\
\text { Content } \\
(\%) \\
\end{array}$ \\
\hline \multirow[t]{39}{*}{ OMP-16-C3 } & 40.5 & 7.4 & 1.432 & 0.797 & 44.3 \\
\hline & 41.5 & 7.2 & 1.455 & 0.814 & 44.1 \\
\hline & 42.5 & 7.4 & 1.471 & 0.813 & 44.7 \\
\hline & 43.5 & 7.3 & 1.421 & 0.796 & 44.0 \\
\hline & 44.5 & 7.3 & 1.517 & 0.854 & 43.7 \\
\hline & 45.5 & 7.4 & 1.433 & 0.800 & 44.2 \\
\hline & 46.5 & 7.0 & 1.457 & 0.826 & 43.3 \\
\hline & 47.5 & 7.0 & 1.416 & 0.802 & 43.4 \\
\hline & 48.5 & 6.6 & 1.410 & 0.791 & 43.9 \\
\hline & 49.5 & 6.5 & 1.404 & 0.785 & 44.1 \\
\hline & 50.5 & 6.4 & 1.442 & 0.812 & 43.7 \\
\hline & 51.5 & 6.7 & 1.441 & 0.807 & 44.0 \\
\hline & 52.5 & 6.7 & 1.343 & 0.743 & 44.7 \\
\hline & 53.5 & 6.7 & 1.392 & 0.765 & 45.0 \\
\hline & 54.5 & 7.3 & 1.320 & 0.669 & 49.3 \\
\hline & 55.5 & 7.3 & 1.303 & 0.668 & 48.7 \\
\hline & 56.5 & 7.2 & 1.351 & 0.718 & 46.9 \\
\hline & 57.5 & 7.3 & 1.388 & 0.724 & 47.8 \\
\hline & 58.5 & 7.3 & 1.379 & 0.711 & 48.4 \\
\hline & 59.5 & 7.0 & 1.345 & 0.698 & 48.1 \\
\hline & 60.5 & 7.3 & 1.417 & 0.763 & 46.2 \\
\hline & 61.5 & 7.0 & 1.406 & 0.790 & 43.8 \\
\hline & 62.5 & 6.9 & 1.531 & 0.875 & 42.8 \\
\hline & 63.5 & 6.8 & 1.426 & 0.806 & 43.5 \\
\hline & 64.5 & 7.2 & 1.446 & 0.803 & 44.5 \\
\hline & 65.5 & 7.0 & 1.390 & 0.803 & 42.2 \\
\hline & 66.5 & 7.0 & 1.513 & 0.885 & 41.5 \\
\hline & 67.5 & 7.3 & 1.418 & 0.805 & 43.2 \\
\hline & 68.5 & 7.6 & 1.380 & 0.772 & 44.1 \\
\hline & 69.5 & 7.6 & 1.467 & 0.819 & 44.2 \\
\hline & 70.5 & 7.5 & 1.361 & 0.772 & 43.3 \\
\hline & 71.5 & 7.6 & 1.375 & 0.779 & 43.3 \\
\hline & 72.5 & 7.4 & 1.504 & 0.849 & 43.6 \\
\hline & 73.5 & 7.4 & 1.428 & 0.793 & 44.5 \\
\hline & 74.5 & 7.4 & 1.108 & 0.620 & 44.0 \\
\hline & 75.5 & 8.4 & 1.407 & 0.739 & 47.5 \\
\hline & 76.5 & 8.6 & 1.381 & 0.759 & 45.0 \\
\hline & 77.5 & 8.7 & 1.450 & 0.796 & 45.1 \\
\hline & 78.5 & 8.8 & 1.393 & 0.702 & 49.6 \\
\hline
\end{tabular}


Table B15. (Cont) LOI data for Old Mill Pond core 3.

\begin{tabular}{|c|c|c|c|c|c|}
\hline Core-Drive & $\begin{array}{l}\text { Depth } \\
(\mathrm{cm})\end{array}$ & $\begin{array}{c}\text { Organic } \\
\text { Matter } \\
(\%)\end{array}$ & $\begin{array}{c}\text { Wet bulk } \\
\text { Density } \\
\left(\mathrm{g} / \mathrm{cm}^{3}\right)\end{array}$ & $\begin{array}{c}\text { Dry Bulk } \\
\text { Density } \\
\left(\mathrm{g} / \mathrm{cm}^{3}\right)\end{array}$ & $\begin{array}{c}\text { Water } \\
\text { Content } \\
\text { (\%) }\end{array}$ \\
\hline \multirow[t]{37}{*}{ OMP-16-C3 } & 79.5 & 9.0 & 1.403 & 0.709 & 49.5 \\
\hline & 80.5 & 8.6 & 1.393 & 0.732 & 47.5 \\
\hline & 81.5 & 8.8 & 1.425 & 0.759 & 46.7 \\
\hline & 82.5 & 8.7 & 1.403 & 0.743 & 47.0 \\
\hline & 83.5 & 8.6 & 1.417 & 0.730 & 48.5 \\
\hline & 84.5 & 9.0 & 1.482 & 0.836 & 43.6 \\
\hline & 85.5 & 9.4 & 1.411 & 0.765 & 45.8 \\
\hline & 86.5 & 9.4 & 1.319 & 0.650 & 50.7 \\
\hline & 87.5 & 9.0 & 1.432 & 0.767 & 46.4 \\
\hline & 88.5 & 8.3 & 1.476 & 0.810 & 45.1 \\
\hline & 89.5 & 8.7 & 1.420 & 0.782 & 44.9 \\
\hline & 90.5 & 8.7 & 1.464 & 0.804 & 45.1 \\
\hline & 91.5 & 8.4 & 1.347 & 0.666 & 50.6 \\
\hline & 92.5 & 7.8 & 1.480 & 0.778 & 47.4 \\
\hline & 93.5 & 7.7 & 1.499 & 0.834 & 44.4 \\
\hline & 94.5 & 7.5 & 1.503 & 0.849 & 43.5 \\
\hline & 95.5 & 7.6 & 1.469 & 0.837 & 43.0 \\
\hline & 96.5 & 7.9 & 1.435 & 0.811 & 43.5 \\
\hline & 97.5 & 7.8 & 1.474 & 0.832 & 43.6 \\
\hline & 98.5 & 6.8 & 1.560 & 0.930 & 40.4 \\
\hline & 99.5 & 8.1 & 1.441 & 0.780 & 45.9 \\
\hline & 100.5 & 8.4 & 1.428 & 0.776 & 45.7 \\
\hline & 101.5 & 9.1 & 1.381 & 0.723 & 47.6 \\
\hline & 102.5 & 8.9 & 1.421 & 0.730 & 48.6 \\
\hline & 103.5 & 10.8 & 1.308 & 0.566 & 56.7 \\
\hline & 104.5 & 10.7 & 1.213 & 0.484 & 60.1 \\
\hline & 105.5 & 10.1 & 1.279 & 0.542 & 57.6 \\
\hline & 106.5 & 10.4 & 1.273 & 0.521 & 59.1 \\
\hline & 107.5 & 9.3 & 1.305 & 0.593 & 54.6 \\
\hline & 108.5 & 9.5 & 1.347 & 0.631 & 53.2 \\
\hline & 109.5 & 9.9 & 1.240 & 0.535 & 56.9 \\
\hline & 110.5 & 10.8 & 1.303 & 0.539 & 58.6 \\
\hline & 111.5 & 8.4 & 1.340 & 0.655 & 51.1 \\
\hline & 112.5 & 8.3 & 1.399 & 0.700 & 50.0 \\
\hline & 113.5 & 7.8 & 1.412 & 0.731 & 48.2 \\
\hline & 114.5 & 7.1 & 1.505 & 0.865 & 42.5 \\
\hline & 115.5 & 6.8 & 1.377 & 0.764 & 44.5 \\
\hline
\end{tabular}


Table B15. (Cont) LOI data for Old Mill Pond core 3.

\begin{tabular}{|c|c|c|c|c|c|}
\hline Core-Drive & $\begin{array}{l}\text { Depth } \\
(\mathrm{cm})\end{array}$ & $\begin{array}{c}\text { Organic } \\
\text { Matter } \\
\text { (\%) }\end{array}$ & $\begin{array}{c}\text { Wet bulk } \\
\text { Density } \\
\left(\mathrm{g} / \mathrm{cm}^{3}\right)\end{array}$ & $\begin{array}{c}\text { Dry Bulk } \\
\text { Density } \\
\left(\mathrm{g} / \mathrm{cm}^{3}\right)\end{array}$ & $\begin{array}{c}\text { Water } \\
\text { Content } \\
(\%)\end{array}$ \\
\hline \multirow[t]{39}{*}{ OMP-16-C3 } & 116.5 & 7.2 & 1.479 & 0.843 & 43.0 \\
\hline & 117.5 & 7.2 & 1.479 & 0.831 & 43.8 \\
\hline & 118.5 & 7.6 & 1.511 & 0.828 & 45.2 \\
\hline & 119.5 & 7.2 & 1.482 & 0.801 & 46.0 \\
\hline & 120.5 & 7.3 & 1.494 & 0.853 & 42.9 \\
\hline & 121.5 & 7.3 & 1.520 & 0.876 & 42.4 \\
\hline & 122.5 & 9.6 & 1.288 & 0.607 & 52.9 \\
\hline & 123.5 & 11.2 & 1.246 & 0.516 & 58.6 \\
\hline & 124.5 & 11.3 & 1.202 & 0.461 & 61.6 \\
\hline & 125.5 & 11.1 & 1.151 & 0.433 & 62.4 \\
\hline & 126.5 & 10.9 & 1.309 & 0.598 & 54.3 \\
\hline & 127.5 & 10.2 & 1.315 & 0.598 & 54.5 \\
\hline & 128.5 & 9.9 & 1.425 & 0.739 & 48.1 \\
\hline & 129.5 & 10.3 & 1.350 & 0.604 & 55.3 \\
\hline & 130.5 & 10.0 & 1.352 & 0.631 & 53.3 \\
\hline & 131.5 & 10.0 & 1.356 & 0.641 & 52.7 \\
\hline & 132.5 & 10.5 & 1.365 & 0.666 & 51.2 \\
\hline & 133.5 & 10.3 & 1.349 & 0.629 & 53.4 \\
\hline & 134.5 & 10.2 & 1.302 & 0.566 & 56.5 \\
\hline & 135.5 & 9.8 & 1.306 & 0.599 & 54.1 \\
\hline & 136.5 & 9.1 & 1.384 & 0.715 & 48.3 \\
\hline & 137.5 & 9.0 & 1.359 & 0.654 & 51.9 \\
\hline & 138.5 & 7.1 & 1.613 & 0.970 & 39.9 \\
\hline & 139.5 & 9.4 & 1.408 & 0.790 & 43.9 \\
\hline & 140.5 & 10.5 & 1.395 & 0.730 & 47.7 \\
\hline & 141.5 & 11.3 & 1.429 & 0.820 & 42.6 \\
\hline & 142.5 & 11.7 & 1.475 & 0.925 & 37.3 \\
\hline & 143.5 & 11.8 & 1.485 & 0.932 & 37.2 \\
\hline & 144.5 & 12.1 & 1.573 & 0.977 & 37.9 \\
\hline & 145.5 & 12.9 & 1.472 & 0.867 & 41.1 \\
\hline & 146.5 & 10.0 & 1.588 & 1.026 & 35.4 \\
\hline & 147.5 & 10.3 & 1.554 & 0.982 & 36.8 \\
\hline & 148.5 & 13.1 & 1.412 & 0.807 & 42.8 \\
\hline & 149.5 & 12.5 & 1.465 & 0.849 & 42.0 \\
\hline & 150.5 & 11.3 & 1.500 & 0.886 & 40.9 \\
\hline & 151.5 & 11.3 & 1.462 & 0.861 & 41.1 \\
\hline & 152.5 & 10.4 & 1.481 & 0.886 & 40.2 \\
\hline & 153.5 & 11.0 & 1.485 & 0.854 & 42.5 \\
\hline & 154.5 & 9.3 & 1.489 & 0.935 & 37.2 \\
\hline
\end{tabular}


Table B15. (Cont) LOI data for Old Mill Pond core 3.

\begin{tabular}{|c|c|c|c|c|c|}
\hline Core-Drive & $\begin{array}{l}\text { Depth } \\
(\mathrm{cm})\end{array}$ & $\begin{array}{c}\text { Organic } \\
\text { Matter } \\
(\%)\end{array}$ & $\begin{array}{c}\text { Wet bulk } \\
\text { Density } \\
\left(\mathrm{g} / \mathrm{cm}^{3}\right)\end{array}$ & $\begin{array}{c}\text { Dry Bulk } \\
\text { Density } \\
\left(\mathrm{g} / \mathrm{cm}^{3}\right)\end{array}$ & $\begin{array}{c}\text { Water } \\
\text { Content } \\
(\%)\end{array}$ \\
\hline \multirow[t]{11}{*}{ OMP-16-C3 } & 155.5 & 9.6 & 1.421 & 0.856 & 39.8 \\
\hline & 156.5 & 9.5 & 1.556 & 0.930 & 40.2 \\
\hline & 157.5 & 9.0 & 1.628 & 1.044 & 35.9 \\
\hline & 158.5 & 9.9 & 1.515 & 0.938 & 38.1 \\
\hline & 159.5 & 10.2 & 1.497 & 0.896 & 40.1 \\
\hline & 160.5 & 9.4 & 1.580 & 0.988 & 37.5 \\
\hline & 161.5 & 11.1 & 1.276 & 0.792 & 37.9 \\
\hline & 162.5 & 11.0 & 1.524 & 0.916 & 39.9 \\
\hline & 163.5 & 11.7 & 1.532 & 0.933 & 39.1 \\
\hline & 164.5 & 10.3 & 1.571 & 0.979 & 37.7 \\
\hline & 165.5 & 11.5 & 1.489 & 0.906 & 39.2 \\
\hline
\end{tabular}


Table B16. Whole-core susceptibility ( $\kappa$ ) for Old Mill Pond core 3.

\begin{tabular}{|c|c|c|c|c|}
\hline Core-Drive & $\begin{array}{l}\text { Depth in Core } \\
\text { (cm) }\end{array}$ & $\begin{array}{c}\text { Corrected } \\
\text { Depth in Core } \\
\text { (cm) }\end{array}$ & $\begin{array}{c}\kappa \\
\left(10^{-5} \text { Relative }\right. \\
\text { SI Units }) \\
\end{array}$ & $\begin{array}{c}\text { Edited } \kappa \\
\left(10^{-5} \text { Relative }\right. \\
\text { SI Units })\end{array}$ \\
\hline \multirow[t]{37}{*}{ OMP-16-C3 } & 0 & - & 8.4 & - \\
\hline & 3 & 3 & 12.6 & 12.6 \\
\hline & 6 & 6 & 13.9 & 13.9 \\
\hline & 9 & 9 & 14.6 & 14.6 \\
\hline & 12 & 12 & 15.6 & 15.6 \\
\hline & 15 & 15 & 15.9 & 15.9 \\
\hline & 18 & 18 & 16.2 & 16.2 \\
\hline & 21 & 21 & 16.1 & 16.1 \\
\hline & 24 & 24 & 16.0 & 16.0 \\
\hline & 27 & 27 & 16.7 & 16.7 \\
\hline & 30 & 30 & 17.8 & 17.8 \\
\hline & 33 & 33 & 18.8 & 18.8 \\
\hline & 36 & 36 & 19.5 & 19.5 \\
\hline & 39 & 39 & 18.9 & 18.9 \\
\hline & 42 & 42 & 17.9 & 17.9 \\
\hline & 45 & 45 & 17.6 & 17.6 \\
\hline & 48 & 48 & 16.5 & 16.5 \\
\hline & 51 & 51 & 15.4 & 15.4 \\
\hline & 54 & 54 & 14.9 & 14.9 \\
\hline & 57 & 57 & 15.0 & 15.0 \\
\hline & 60 & 60 & 16.0 & 16.0 \\
\hline & 63 & 63 & 17.2 & 17.2 \\
\hline & 66 & 66 & 18.2 & 18.2 \\
\hline & 69 & 69 & 18.6 & 18.6 \\
\hline & 72 & 72 & 18.9 & 18.9 \\
\hline & 75 & 75 & 19.1 & 19.1 \\
\hline & 78 & 78 & 20.7 & 20.7 \\
\hline & 81 & 81 & 21.3 & 21.3 \\
\hline & 84 & 84 & 22.2 & 22.2 \\
\hline & 87 & 87 & 21.0 & 21.0 \\
\hline & 90 & 90 & 20.6 & 20.6 \\
\hline & 93 & 93 & 20.3 & 20.3 \\
\hline & 96 & 96 & 21.4 & 21.4 \\
\hline & 99 & 99 & 21.3 & 21.3 \\
\hline & 102 & 102 & 18.2 & 18.2 \\
\hline & 105 & 105 & 14.5 & 14.5 \\
\hline & 108 & 108 & 15.3 & 15.3 \\
\hline
\end{tabular}


Table B16. (Cont) Whole-core susceptibility (к) for Old Mill Pond core 3.

\begin{tabular}{|c|c|c|c|c|}
\hline Core-Drive & $\begin{array}{l}\text { Depth in Core } \\
\text { (cm) }\end{array}$ & $\begin{array}{c}\text { Corrected } \\
\text { Depth in Core } \\
\text { (cm) }\end{array}$ & $\begin{array}{c}\kappa \\
\left(10^{-5} \text { Relative }\right. \\
\text { SI Units }) \\
\end{array}$ & $\begin{array}{c}\text { Edited } \kappa \\
\left(10^{-5} \text { Relative }\right. \\
\text { SI Units })\end{array}$ \\
\hline \multirow[t]{19}{*}{ OMP-16-C3 } & 111 & 111 & 16.1 & 16.1 \\
\hline & 114 & 114 & 17.4 & 17.4 \\
\hline & 117 & 117 & 18.0 & 18.0 \\
\hline & 120 & 120 & 17.2 & 17.2 \\
\hline & 123 & 123 & 14.3 & 14.3 \\
\hline & 126 & 126 & 14 & 14 \\
\hline & 129 & 129 & 15.1 & 15.1 \\
\hline & 132 & 132 & 15.2 & 15.2 \\
\hline & 135 & 135 & 13.9 & 13.9 \\
\hline & 138 & 138 & 14.3 & 14.3 \\
\hline & 141 & 141 & 16.1 & 16.1 \\
\hline & 144 & 144 & 15.7 & 15.7 \\
\hline & 147 & 147 & 13.1 & 13.1 \\
\hline & 150 & 150 & 11.6 & 11.6 \\
\hline & 153 & 153 & 11.4 & 11.4 \\
\hline & 156 & 156 & 11.2 & 11.2 \\
\hline & 159 & 159 & 10.7 & 10.7 \\
\hline & 162 & 162 & 10.4 & 10.4 \\
\hline & 165 & - & 3.8 & - \\
\hline
\end{tabular}


Table B17. LOI data for Old Mill Pond core 5.

\begin{tabular}{|c|c|c|c|c|c|}
\hline Core-Drive & $\begin{array}{l}\text { Depth } \\
(\mathrm{cm})\end{array}$ & $\begin{array}{c}\text { Organic } \\
\text { Matter } \\
(\%) \\
\end{array}$ & $\begin{array}{c}\text { Wet bulk } \\
\text { Density } \\
\left(\mathrm{g} / \mathrm{cm}^{3}\right) \\
\end{array}$ & $\begin{array}{c}\text { Dry Bulk } \\
\text { Density } \\
\left(\mathrm{g} / \mathrm{cm}^{3}\right) \\
\end{array}$ & $\begin{array}{c}\text { Water } \\
\text { Content } \\
(\%) \\
\end{array}$ \\
\hline \multirow[t]{38}{*}{ OMP-16-C5 } & 0.5 & 11.4 & 0.969 & 0.431 & 55.5 \\
\hline & 1.5 & 11.0 & 1.251 & 0.554 & 55.7 \\
\hline & 2.5 & 10.9 & 1.127 & 0.512 & 54.6 \\
\hline & 3.5 & 11.1 & 1.294 & 0.552 & 57.3 \\
\hline & 4.5 & 10.8 & 1.283 & 0.583 & 54.6 \\
\hline & 5.5 & 10.9 & 1.188 & 0.531 & 55.3 \\
\hline & 6.5 & 11.1 & 1.195 & 0.513 & 57.1 \\
\hline & 7.5 & 11.5 & 1.343 & 0.602 & 55.2 \\
\hline & 8.5 & 10.6 & 1.213 & 0.540 & 55.5 \\
\hline & 9.5 & 10.2 & 1.194 & 0.538 & 54.9 \\
\hline & 10.5 & 9.7 & 1.275 & 0.610 & 52.2 \\
\hline & 11.5 & 9.8 & 1.271 & 0.599 & 52.9 \\
\hline & 12.5 & 9.6 & 1.423 & 0.707 & 50.3 \\
\hline & 13.5 & 9.6 & 1.197 & 0.604 & 49.5 \\
\hline & 14.5 & 9.1 & 1.352 & 0.671 & 50.4 \\
\hline & 15.5 & 9.5 & 1.365 & 0.662 & 51.5 \\
\hline & 16.5 & 9.2 & 1.179 & 0.599 & 49.2 \\
\hline & 17.5 & 8.9 & 1.377 & 0.718 & 47.9 \\
\hline & 18.5 & 8.9 & 1.515 & 0.798 & 47.3 \\
\hline & 19.5 & 8.1 & 1.456 & 0.777 & 46.6 \\
\hline & 20.5 & 8.1 & 1.455 & 0.781 & 46.3 \\
\hline & 21.5 & 7.8 & 1.436 & 0.785 & 45.3 \\
\hline & 22.5 & 8.0 & 1.436 & 0.802 & 44.2 \\
\hline & 23.5 & 8.8 & 1.409 & 0.748 & 46.9 \\
\hline & 24.5 & 7.2 & 1.431 & 0.804 & 43.8 \\
\hline & 25.5 & 7.3 & 1.512 & 0.865 & 42.8 \\
\hline & 26.5 & 7.3 & 1.425 & 0.821 & 42.4 \\
\hline & 27.5 & 7.2 & 1.468 & 0.850 & 42.1 \\
\hline & 28.5 & 7.4 & 1.386 & 0.799 & 42.4 \\
\hline & 29.5 & 7.1 & 1.465 & 0.844 & 42.4 \\
\hline & 30.5 & 6.9 & 1.567 & 0.878 & 44.0 \\
\hline & 31.5 & 7.0 & 1.370 & 0.773 & 43.6 \\
\hline & 32.5 & 6.8 & 1.494 & 0.833 & 44.2 \\
\hline & 33.5 & 6.8 & 1.470 & 0.814 & 44.6 \\
\hline & 34.5 & 6.7 & 1.466 & 0.806 & 45.0 \\
\hline & 35.5 & 7.0 & 1.479 & 0.833 & 43.7 \\
\hline & 36.5 & 6.8 & 1.490 & 0.824 & 44.7 \\
\hline & 37.5 & 7.1 & 1.330 & 0.730 & 45.1 \\
\hline
\end{tabular}


Table B17. (Cont) LOI data for Old Mill Pond core 5.

\begin{tabular}{|c|c|c|c|c|c|}
\hline Core-Drive & $\begin{array}{l}\text { Depth } \\
(\mathrm{cm})\end{array}$ & $\begin{array}{c}\text { Organic } \\
\text { Matter } \\
(\%)\end{array}$ & $\begin{array}{c}\text { Wet bulk } \\
\text { Density } \\
\left(\mathrm{g} / \mathrm{cm}^{3}\right)\end{array}$ & $\begin{array}{c}\text { Dry Bulk } \\
\text { Density } \\
\left(\mathrm{g} / \mathrm{cm}^{3}\right)\end{array}$ & $\begin{array}{c}\text { Water } \\
\text { Content } \\
\text { (\%) }\end{array}$ \\
\hline \multirow[t]{38}{*}{ OMP-16-C5 } & 38.5 & 7.2 & 1.335 & 0.707 & 47.0 \\
\hline & 39.5 & 7.2 & 1.310 & 0.704 & 46.3 \\
\hline & 40.5 & 7.4 & 1.402 & 0.745 & 46.9 \\
\hline & 41.5 & 7.7 & 1.345 & 0.692 & 48.6 \\
\hline & 42.5 & 7.3 & 1.432 & 0.765 & 46.6 \\
\hline & 43.5 & 7.2 & 1.463 & 0.796 & 45.6 \\
\hline & 44.5 & 7.1 & 1.468 & 0.819 & 44.2 \\
\hline & 45.5 & 6.9 & 1.478 & 0.836 & 43.4 \\
\hline & 46.5 & 6.9 & 1.512 & 0.858 & 43.3 \\
\hline & 47.5 & 7.0 & 1.519 & 0.869 & 42.8 \\
\hline & 48.5 & 7.2 & 1.341 & 0.766 & 42.9 \\
\hline & 49.5 & 7.1 & 1.516 & 0.876 & 42.2 \\
\hline & 50.5 & 7.2 & 1.387 & 0.797 & 42.5 \\
\hline & 51.5 & 6.9 & 1.506 & 0.878 & 41.7 \\
\hline & 52.5 & 7.5 & 1.438 & 0.769 & 46.5 \\
\hline & 53.5 & 7.4 & 1.389 & 0.796 & 42.7 \\
\hline & 54.5 & 7.5 & 1.511 & 0.853 & 43.5 \\
\hline & 55.5 & 7.6 & 1.479 & 0.826 & 44.2 \\
\hline & 56.5 & 7.2 & 1.303 & 0.727 & 44.2 \\
\hline & 57.5 & 7.8 & 1.398 & 0.709 & 49.3 \\
\hline & 58.5 & 8.1 & 1.404 & 0.745 & 46.9 \\
\hline & 59.5 & 7.2 & 1.486 & 0.852 & 42.7 \\
\hline & 60.5 & 8.2 & 1.452 & 0.772 & 46.8 \\
\hline & 61.5 & 8.7 & 1.388 & 0.710 & 48.8 \\
\hline & 62.5 & 9.1 & 1.402 & 0.724 & 48.4 \\
\hline & 63.5 & 8.2 & 1.422 & 0.758 & 46.7 \\
\hline & 64.5 & 8.5 & 1.428 & 0.774 & 45.8 \\
\hline & 65.5 & 8.6 & 1.468 & 0.807 & 45.0 \\
\hline & 66.5 & 8.7 & 1.446 & 0.824 & 43.0 \\
\hline & 67.5 & 9.2 & 1.425 & 0.729 & 48.8 \\
\hline & 68.5 & 9.2 & 1.374 & 0.673 & 51.0 \\
\hline & 69.5 & 9.0 & 1.442 & 0.770 & 46.6 \\
\hline & 70.5 & 8.5 & 1.465 & 0.762 & 48.0 \\
\hline & 71.5 & 7.6 & 1.439 & 0.803 & 44.2 \\
\hline & 72.5 & 8.2 & 1.451 & 0.797 & 45.1 \\
\hline & 73.5 & 8.2 & 1.357 & 0.758 & 44.1 \\
\hline & 74.5 & 8.6 & 1.528 & 0.841 & 45.0 \\
\hline & 75.5 & 7.8 & 1.437 & 0.747 & 48.0 \\
\hline
\end{tabular}


Table B17. (Cont) LOI data for Old Mill Pond core 5.

\begin{tabular}{lccccc}
\hline \hline Core-Drive & Depth & $\begin{array}{c}\text { Organic } \\
\text { Matter }\end{array}$ & $\begin{array}{c}\text { Wet bulk } \\
\text { Density } \\
\left(\mathrm{g} / \mathrm{cm}^{3}\right)\end{array}$ & $\begin{array}{c}\text { Dry Bulk } \\
\text { Density } \\
\left(\mathrm{g} / \mathrm{cm}^{3}\right)\end{array}$ & $\begin{array}{c}\text { Water } \\
\text { Content } \\
(\%)\end{array}$ \\
\hline OMP-16-C5 & 76.5 & 7.4 & 1.499 & 0.807 & 46.2 \\
& 77.5 & 7.3 & 1.445 & 0.826 & 42.8 \\
& 78.5 & 7.1 & 1.462 & 0.842 & 42.4 \\
& 79.5 & 7.0 & 1.438 & 0.839 & 41.7 \\
80.5 & 7.0 & 1.508 & 0.880 & 41.6 \\
& 81.5 & 7.2 & 1.500 & 0.856 & 42.9 \\
82.5 & 7.1 & 1.488 & 0.860 & 42.2 \\
& 83.5 & 6.8 & 1.510 & 0.873 & 42.2 \\
84.5 & 6.9 & 1.416 & 0.823 & 41.9 \\
85.5 & 6.7 & 1.455 & 0.852 & 41.4 \\
86.5 & 6.6 & 1.470 & 0.876 & 40.4 \\
87.5 & 6.6 & 1.568 & 0.922 & 41.2 \\
88.5 & 6.8 & 1.601 & 0.944 & 41.0 \\
89.5 & 7.1 & 1.468 & 0.870 & 40.7 \\
90.5 & 7.2 & 1.451 & 0.853 & 41.2 \\
91.5 & 6.8 & 1.491 & 0.873 & 41.4 \\
92.5 & 6.6 & 1.457 & 0.851 & 41.6 \\
93.5 & 7.1 & 1.490 & 0.842 & 43.5 \\
94.5 & 6.2 & 1.530 & 0.922 & 39.7 \\
\hline & & & & \\
\hline
\end{tabular}


Table B18. Whole-core susceptibility ( $\kappa)$ for Old Mill Pond core 5.

\begin{tabular}{|c|c|c|c|c|}
\hline Core-Drive & $\begin{array}{l}\text { Depth in } \\
\text { Core } \\
\text { (cm) }\end{array}$ & $\begin{array}{l}\text { Corrected Depth } \\
\text { in Core } \\
(\mathrm{cm})\end{array}$ & $\begin{array}{c}\kappa \\
\left(10^{-5} \text { Relative }\right. \\
\text { SI Units })\end{array}$ & $\begin{array}{c}\text { Edited } \kappa \\
\left(10^{-5} \text { Relative }\right. \\
\text { SI Units })\end{array}$ \\
\hline \multirow[t]{34}{*}{ OMP-16-C5 } & 0 & - & 5.2 & - \\
\hline & 3 & 3 & 12.3 & 12.3 \\
\hline & 6 & 6 & 14.2 & 14.2 \\
\hline & 9 & 9 & 14.8 & 14.8 \\
\hline & 12 & 12 & 15.3 & 15.3 \\
\hline & 15 & 15 & 16.3 & 16.3 \\
\hline & 18 & 18 & 17.2 & 17.2 \\
\hline & 21 & 21 & 19.0 & 19.0 \\
\hline & 24 & 24 & 19.6 & 19.6 \\
\hline & 27 & 27 & 19.9 & 19.9 \\
\hline & 30 & 30 & 20.1 & 20.1 \\
\hline & 33 & 33 & 18.4 & 18.4 \\
\hline & 36 & 36 & 16.3 & 16.3 \\
\hline & 39 & 39 & 15.5 & 15.5 \\
\hline & 42 & 42 & 15.6 & 15.6 \\
\hline & 45 & 45 & 16.5 & 16.5 \\
\hline & 48 & 48 & 18.0 & 18.0 \\
\hline & 51 & 51 & 18.8 & 18.8 \\
\hline & 54 & 54 & 20.3 & 20.3 \\
\hline & 57 & 57 & 20.5 & 20.5 \\
\hline & 60 & 60 & 19.9 & 19.9 \\
\hline & 63 & 63 & 20.9 & 20.9 \\
\hline & 66 & 66 & 21.6 & 21.6 \\
\hline & 69 & 69 & 20.8 & 20.8 \\
\hline & 72 & 72 & 19.5 & 19.5 \\
\hline & 75 & 75 & 19.8 & 19.8 \\
\hline & 78 & 78 & 18.7 & 18.7 \\
\hline & 81 & 81 & 18.9 & 18.9 \\
\hline & 84 & 84 & 19.8 & 19.8 \\
\hline & 87 & 87 & 19.9 & 19.9 \\
\hline & 90 & 90 & 20.3 & 20.3 \\
\hline & 93 & 93 & 19.3 & 19.3 \\
\hline & 96 & - & 12.5 & - \\
\hline & 99 & - & 2.4 & - \\
\hline
\end{tabular}




\section{APPENDIX C}

\section{SEDIMENT CORE AND SURFACE SAMPLE MAGNETIC PROPERTIES \\ FOR LAKE BUTLER, LAKE LITCHFIELD, AND OLD MILL POND}

All surface samples and representative down core lithologies were measured for magnetic concentration, grain size, and minerology parameters. These parameters include susceptibility $(\chi)$, anhysteretic remanent magnetization (ARM), the saturation isothermal remanent magnetization (SIRM), isothermal remanent magnetization (IRM), S-ratio, $\chi \mathrm{ARM} / \chi$, and $\mathrm{SIRM} / \chi$. 


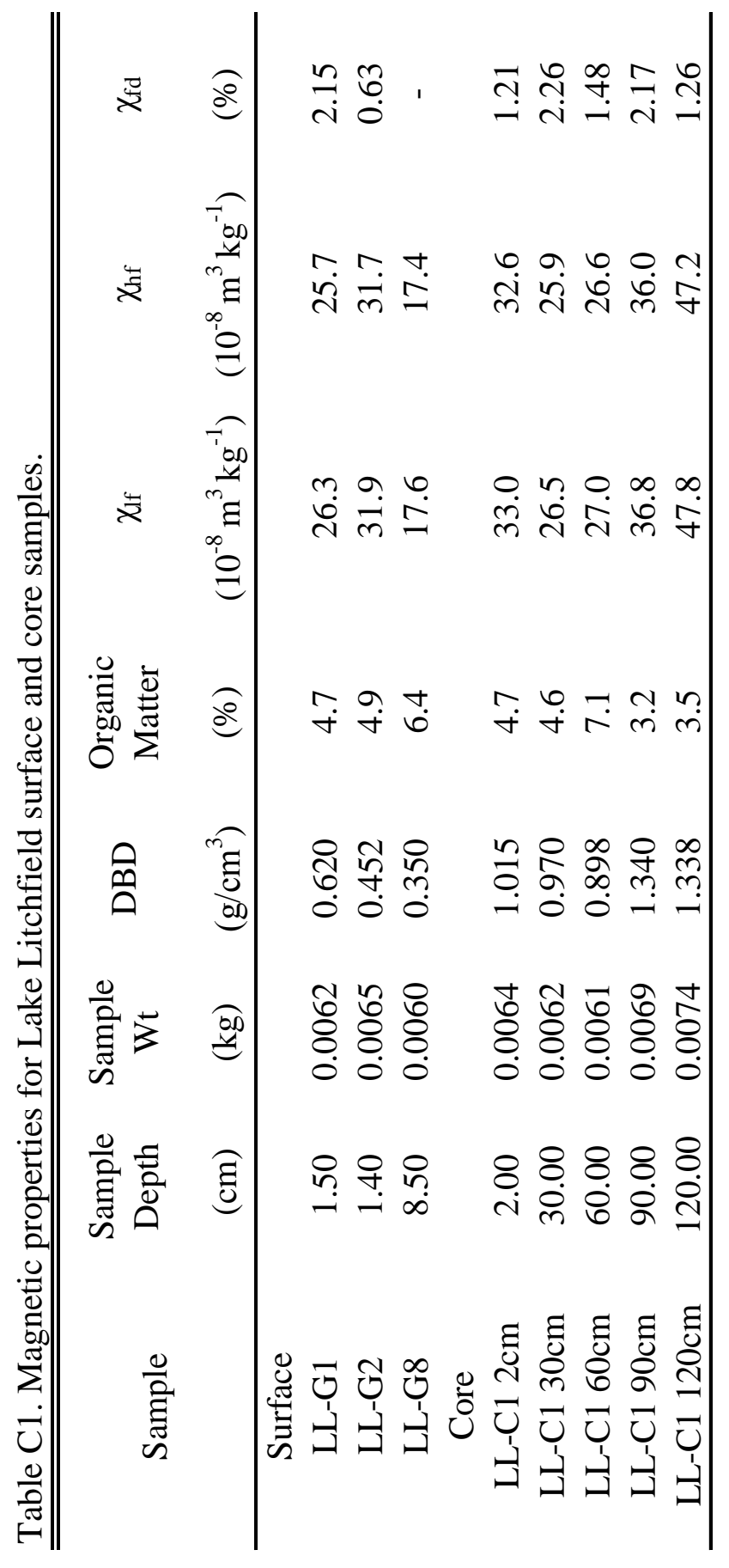




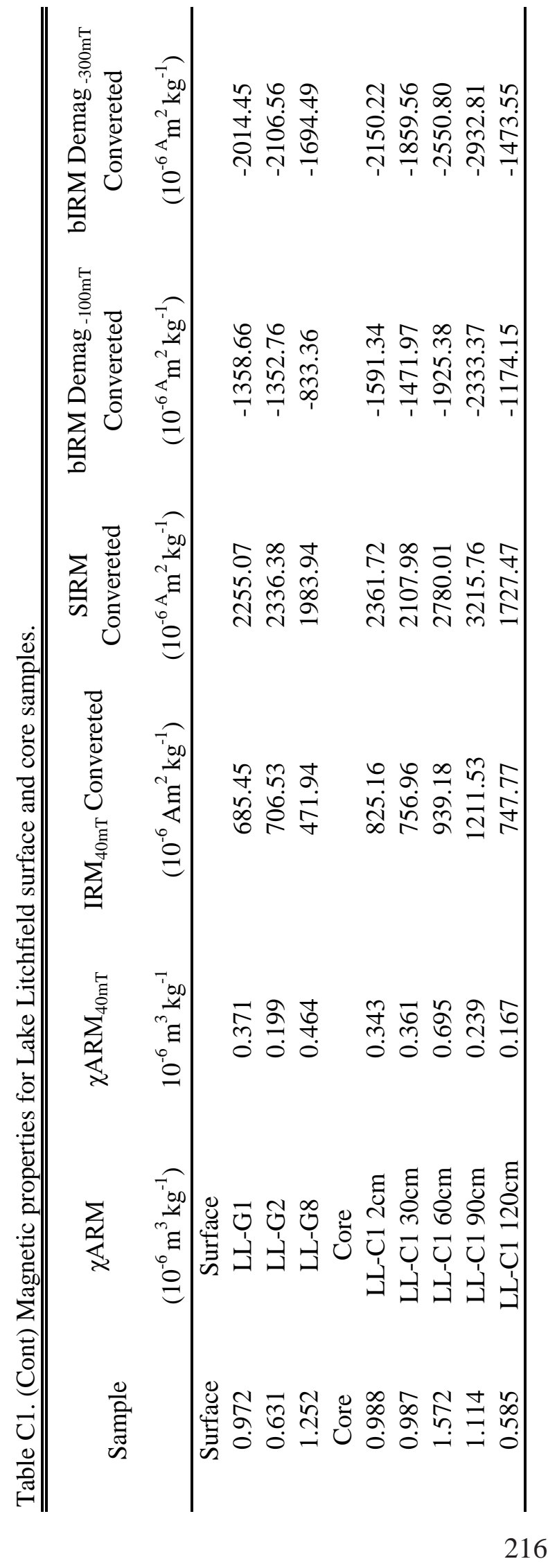


Table C1. (Cont) Magnetic properties for Lake Litchfield surface and core samples.

\begin{tabular}{cccc}
\hline \hline Sample & S-ratio & SIRM/ $\chi$ & $\chi_{\text {ARM }} \chi$ \\
& & $\left(10^{2} \mathrm{~A} / \mathrm{m}\right)$ & \\
\hline Surface & & & \\
LL-G1 & 0.893 & 85.74 & 3.697 \\
LL-G2 & 0.902 & 73.24 & 1.977 \\
LL-G8 & 0.854 & 112.72 & 7.114 \\
Core & & & \\
LL-C1 2cm & 0.910 & 71.57 & 3.993 \\
LL-C1 30cm & 0.882 & 79.55 & 5.826 \\
LL-C1 60cm & 0.918 & 102.96 & 3.027 \\
LL-C1 90cm & 0.912 & 87.38 & 1.223 \\
LL-C1 120cm & 0.853 & 36.14 & \\
\hline
\end{tabular}




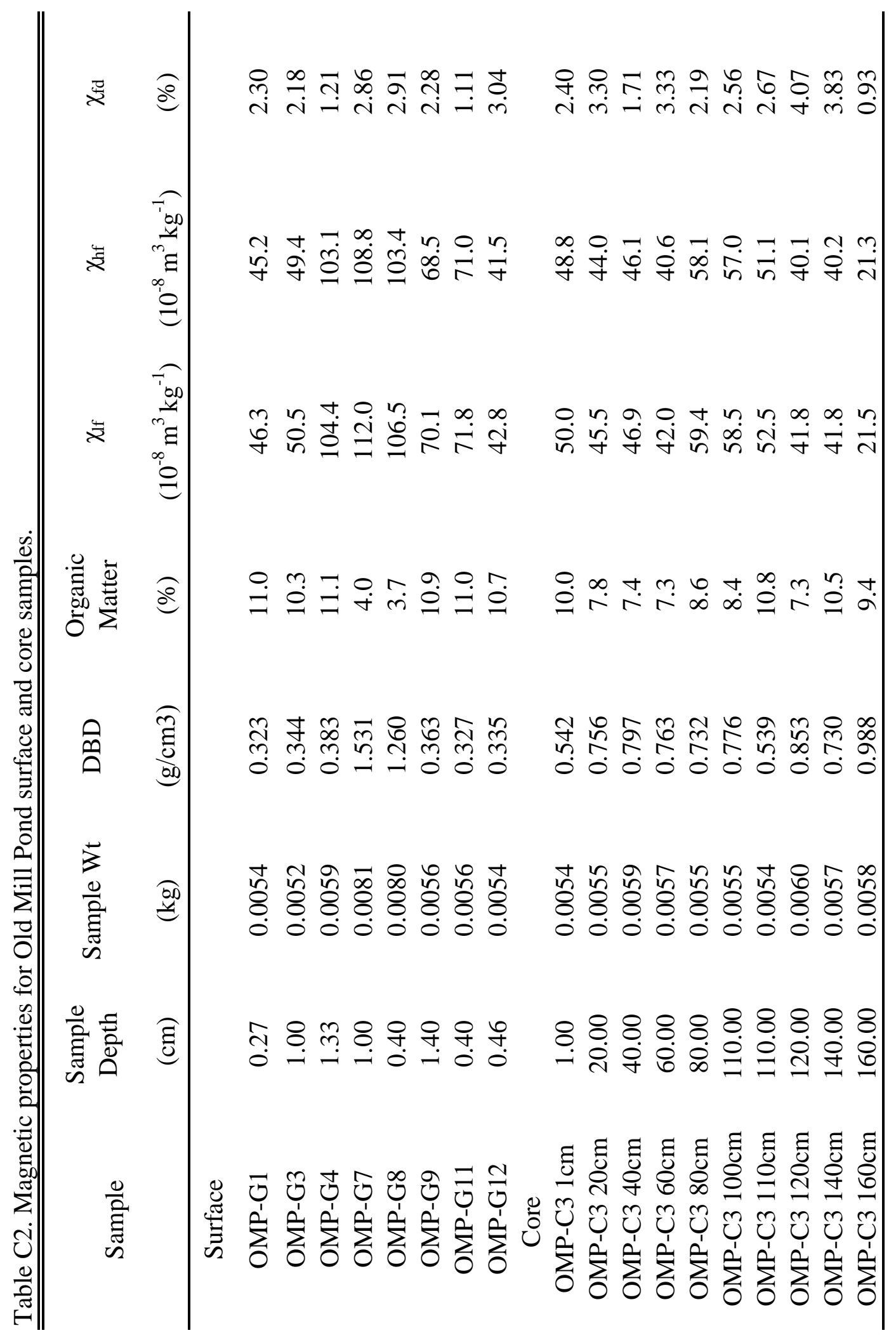




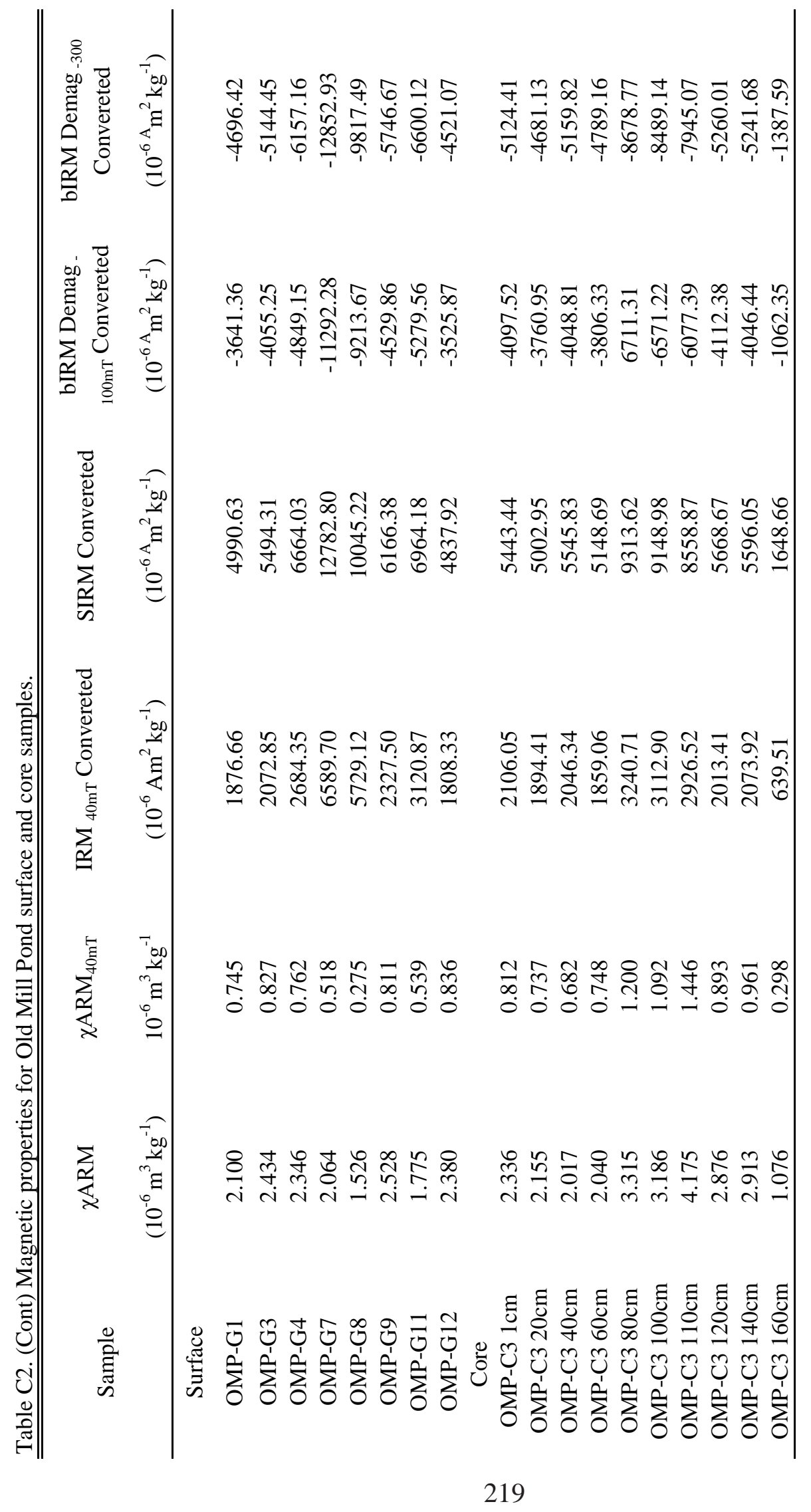


Table C2. (Cont) Magnetic properties for Old Mill Pond surface and core samples.

\begin{tabular}{cccc}
\hline \hline & & $\mathrm{SIRM} / \chi$ & \\
Sample & S-ratio & $\left(10^{2} \mathrm{~A} / \mathrm{m}\right)$ & \\
& & & \\
Surface & & 107.79 & 4.536 \\
OMP-G1 & 0.941 & 108.80 & 4.819 \\
OMP-G3 & 0.936 & 63.83 & 2.247 \\
OMP-G4 & 0.924 & 114.13 & 1.843 \\
OMP-G7 & 1.005 & 94.32 & 1.433 \\
OMP-G8 & 0.977 & 87.97 & 3.607 \\
OMP-G9 & 0.932 & 96.99 & 2.472 \\
OMP-G11 & 0.948 & 113.04 & 5.561 \\
OMP-G12 & 0.935 & & \\
Core & & 108.87 & 4.672 \\
OMP-C3 1cm & 0.941 & 109.95 & 4.737 \\
OMP-C3 20cm & 0.936 & 118.25 & 4.300 \\
OMP-C3 40cm & 0.930 & 122.59 & 4.858 \\
OMP-C3 60cm & 0.930 & 156.79 & 5.581 \\
OMP-C3 80cm & 0.932 & 156.39 & 5.445 \\
OMP-C3 100cm & 0.928 & 163.03 & 7.952 \\
OMP-C3 110cm & 0.928 & 135.61 & 6.880 \\
OMP-C3 120cm & 0.928 & 133.88 & 6.970 \\
OMP-C3 140cm & 0.937 & 76.68 & 5.006 \\
OMP-C3 160cm & 0.842 & & \\
\hline
\end{tabular}




\section{APPENDIX D}

\section{INDIVIDUAL SEDIMENT CORE LITHOLOGY AND SEDIMENT PROPERTIES}

FOR LAKE BUTLER, LAKE LITCHFIELD, AND OLD MILL POND

Lithology, organic matter content, dry bulk density, and whole-core susceptibility were analyzed on all cores for Lake Butler, Lake Litchfield, and Old Mill Pond. 


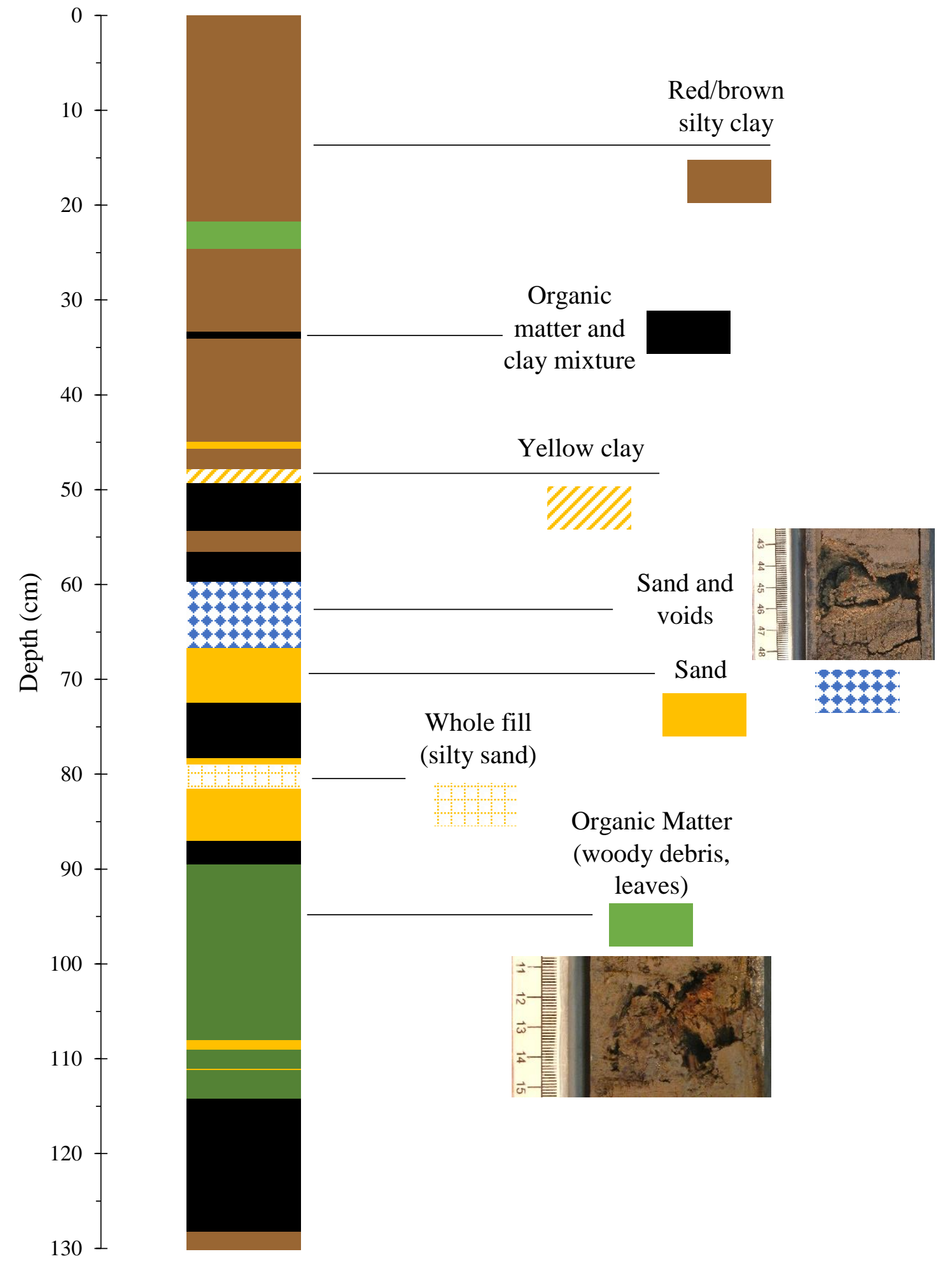

Figure D1. Detailed lithology description for the Lake Butler delta top core LB-16-C1. 


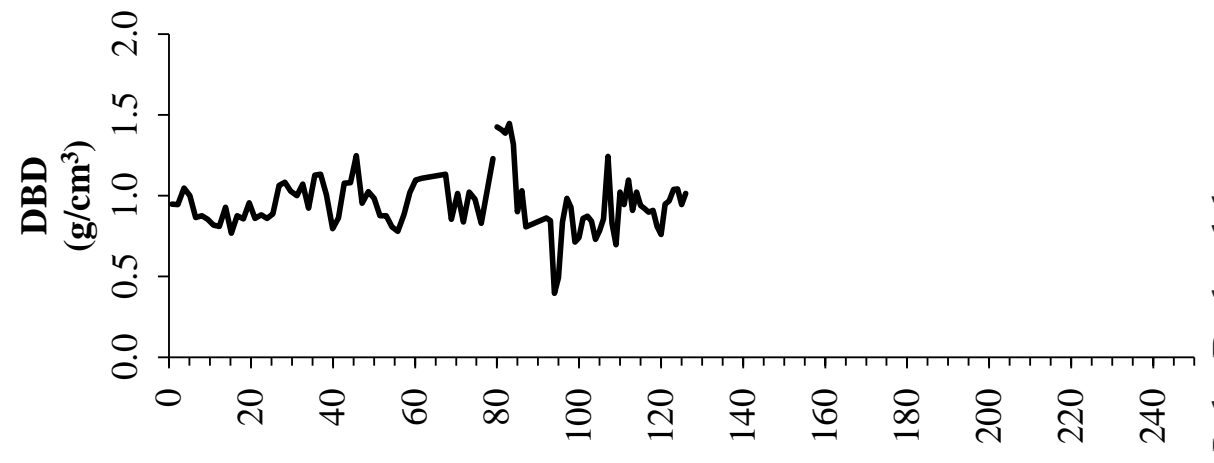

0
0
0
0
0
0
0
0
0
0
0
0
0
0
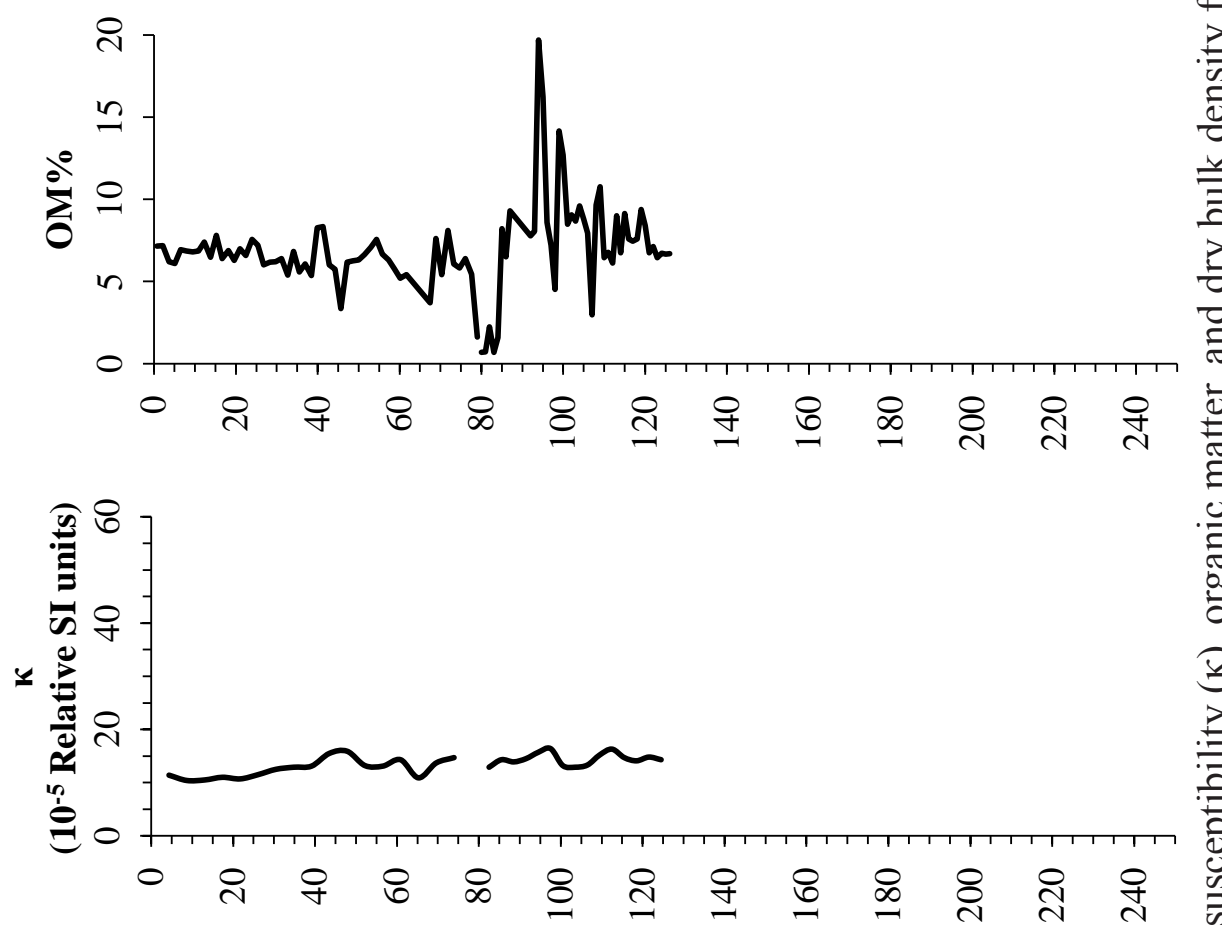

若

जิ.

․ㅡㅁ

률

8 호응

잉

ㄴำ

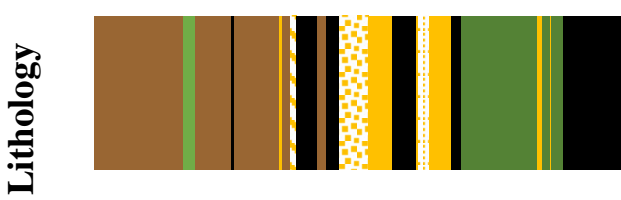

负

命

ช0م

然江

Е气

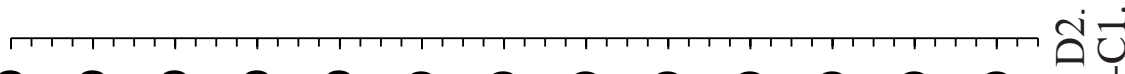

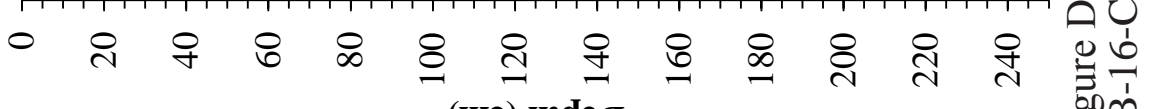

(uі) ч1да

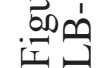




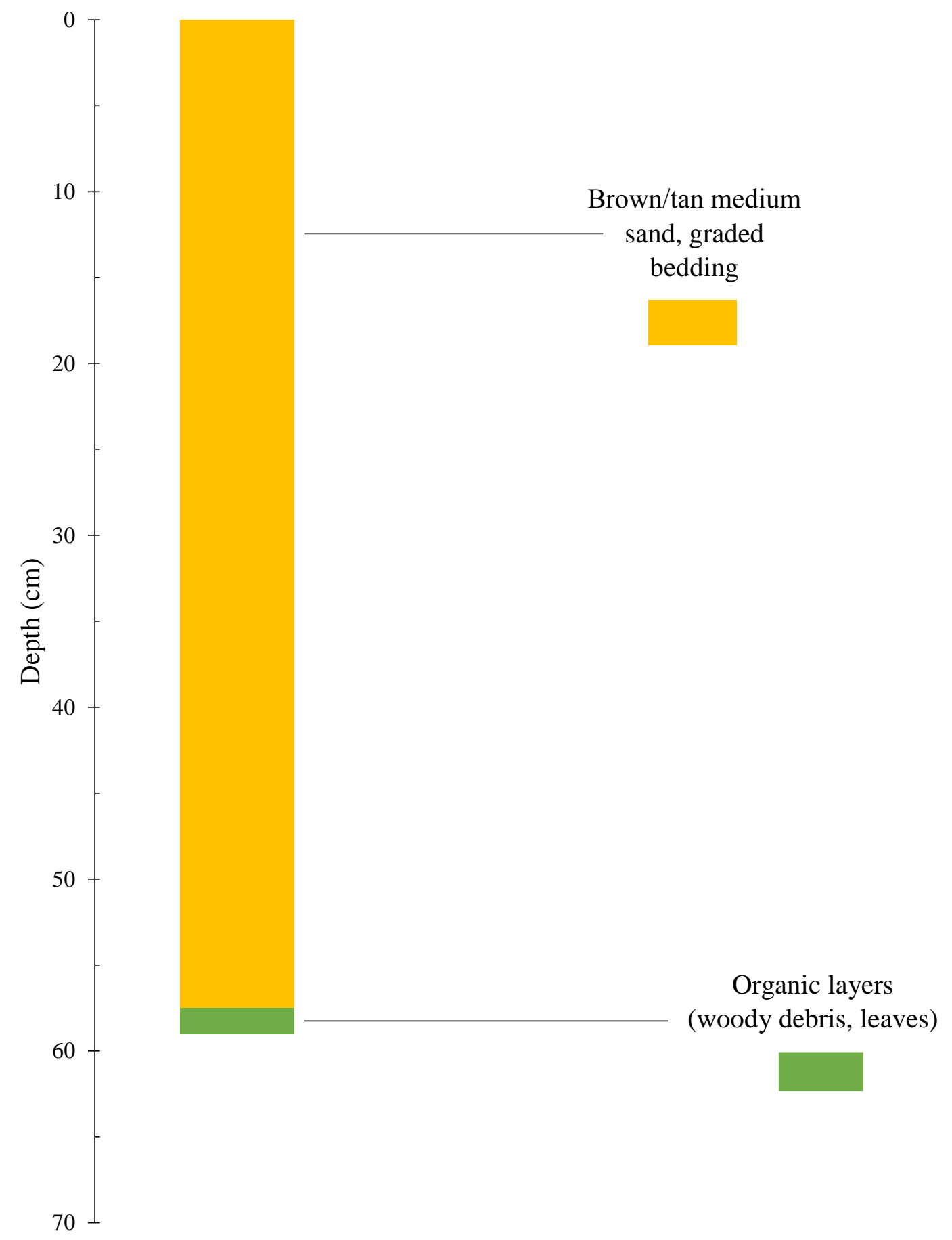

Figure D3. Detailed lithology description for Lake Litchfield sediment core LL-16C3. 

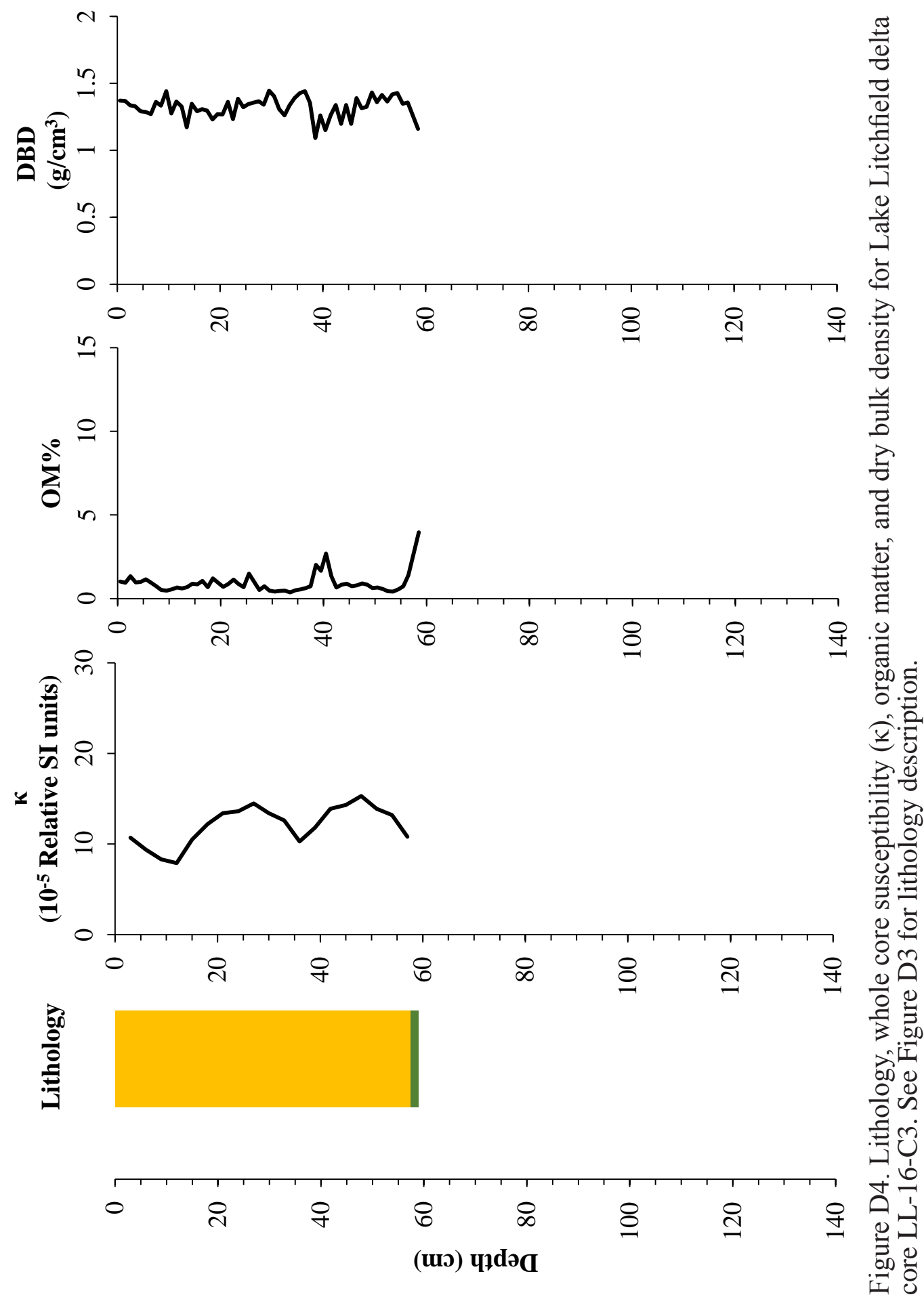


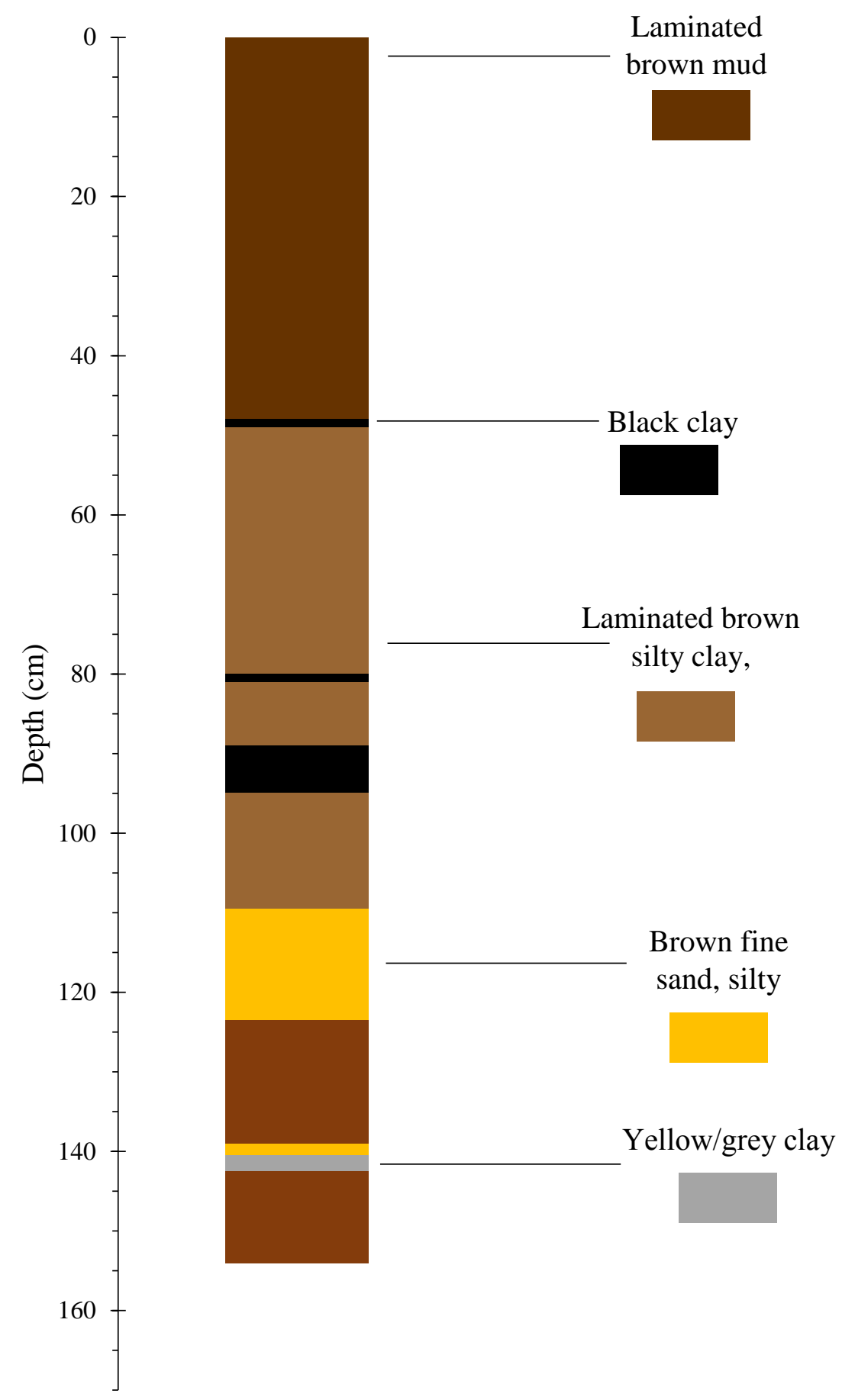

Figure D5. Detailed lithology description for Old Mill Pond sediment core OMP-16-C2. 


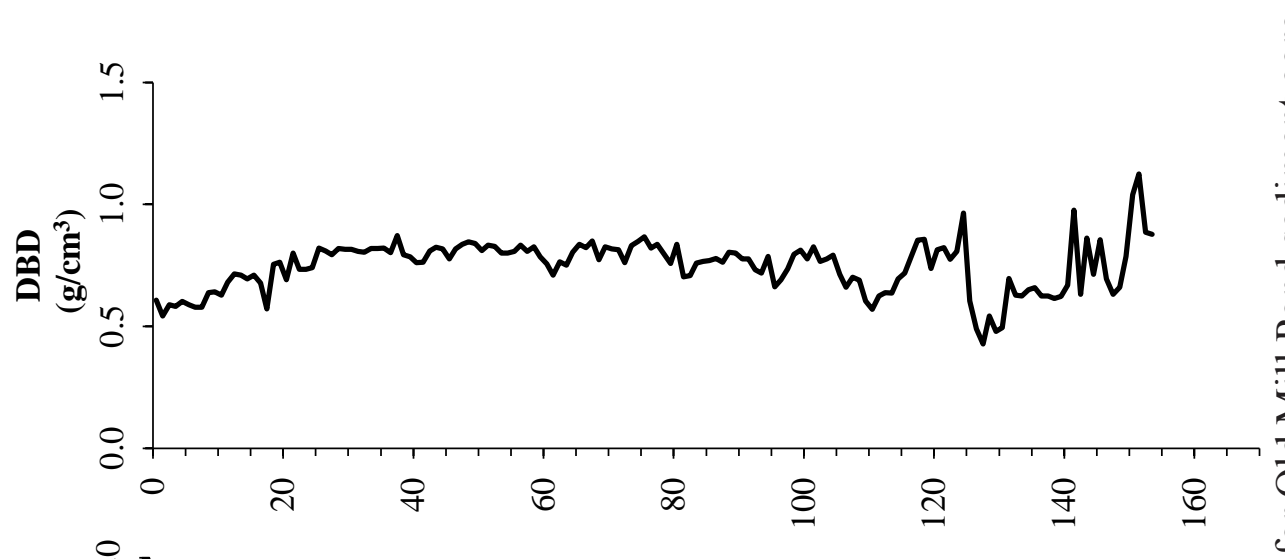

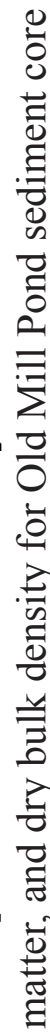

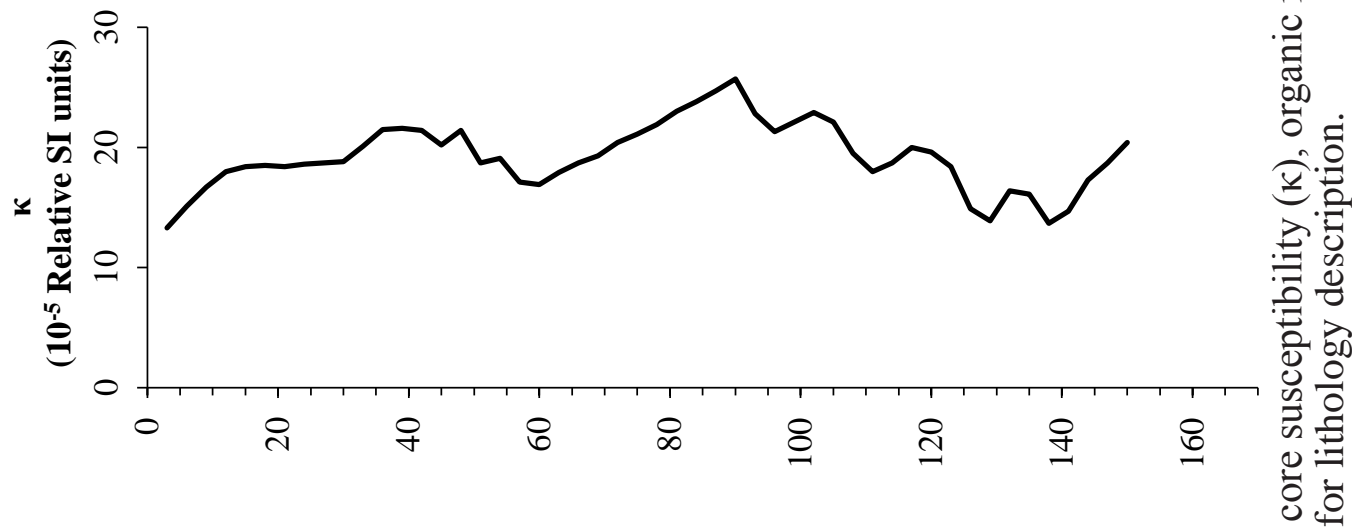

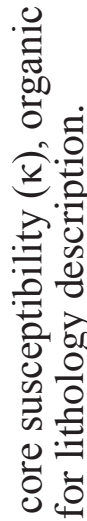
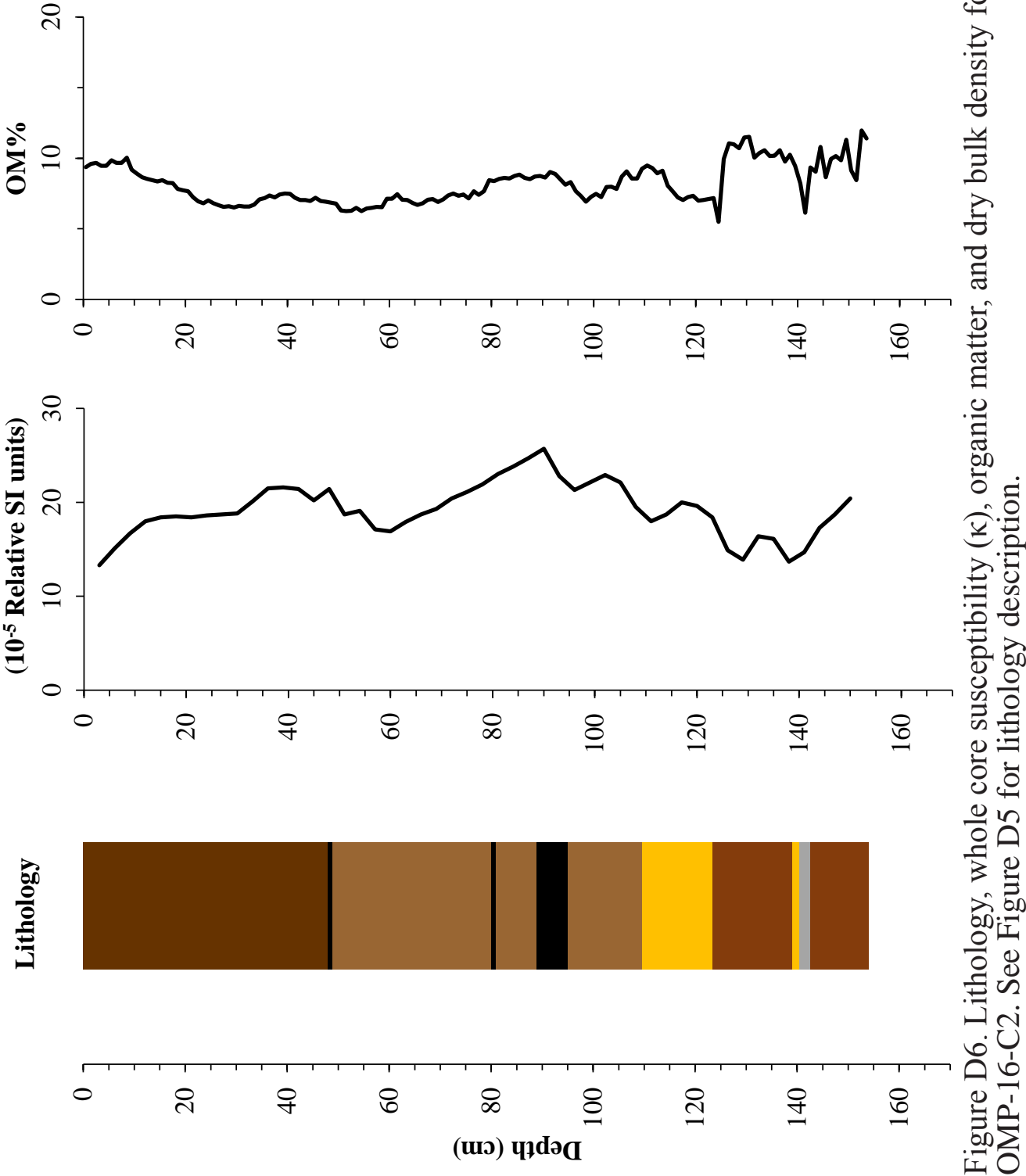


\section{APPENDIX E LAND COVER CHANGE FOR HASKELL RUN, RITCHIE RUN, AND MUD BROOK}

Haskell Run, Ritchie Run and Mud Brook watersheds were assessed for land cover change in the year 1985, 1996, 2001, 2006, and 2010 using NOAA’s Coastal Change Analysis Program (C-Cap) (Digital Coast, 2016a). The cell sizes for the land cover data was 30 X 30 meters. Impervious land cover values were determined by multiplying a specific coefficient for each land cover class by the area for each site. Land cover class coefficients were calculated using NOAA's Impervious Surface Analysis Tool (ISAT) accounting for high, medium, and low values based on the population density or people per square mile. 


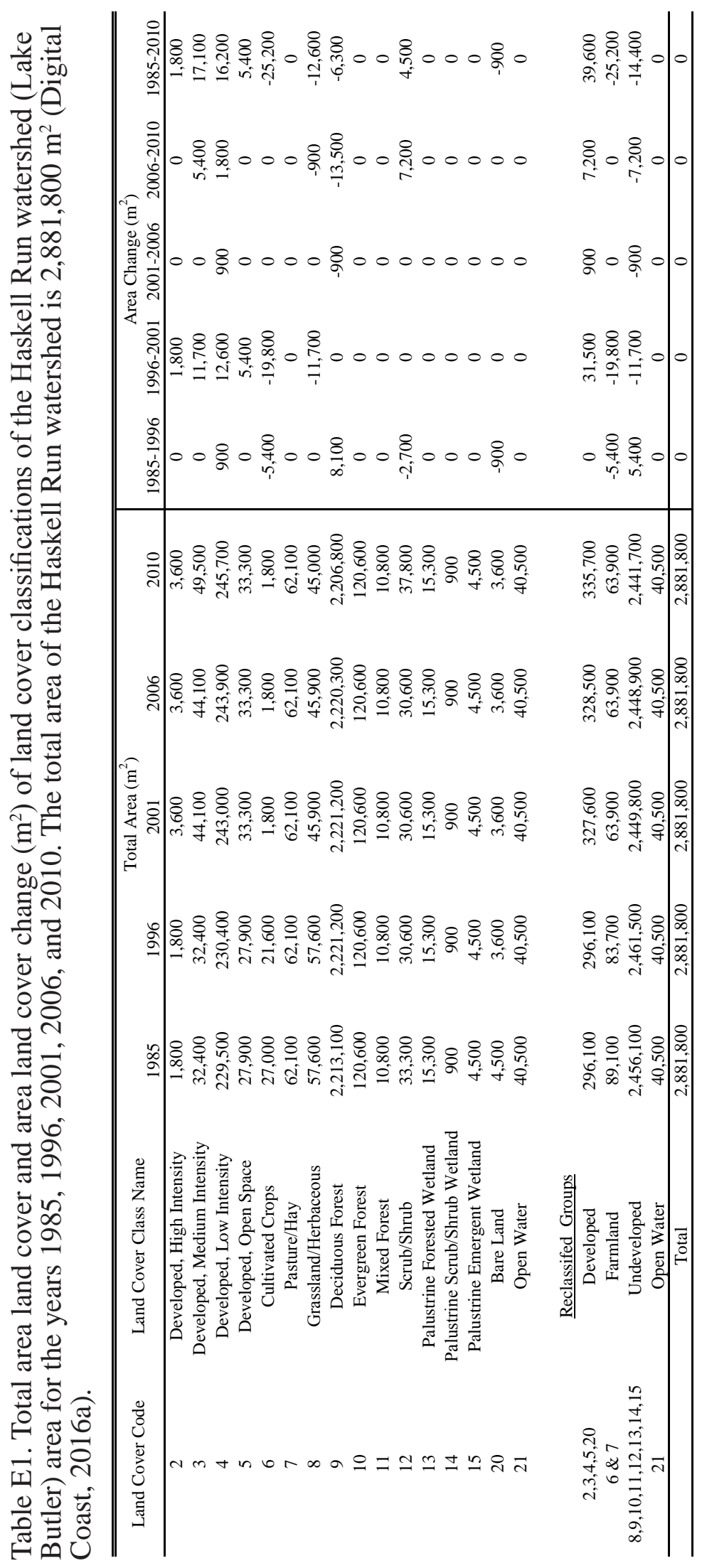




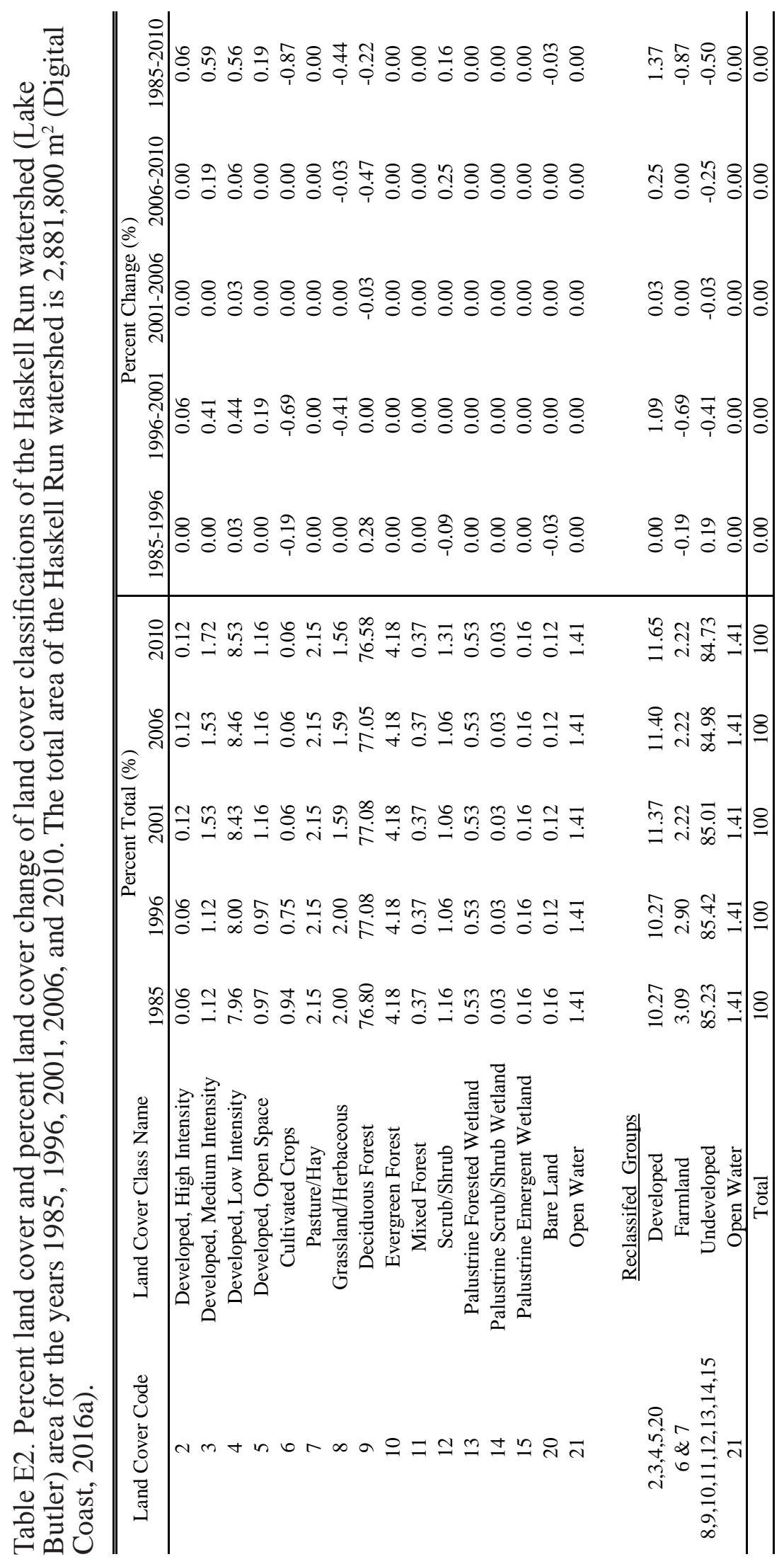




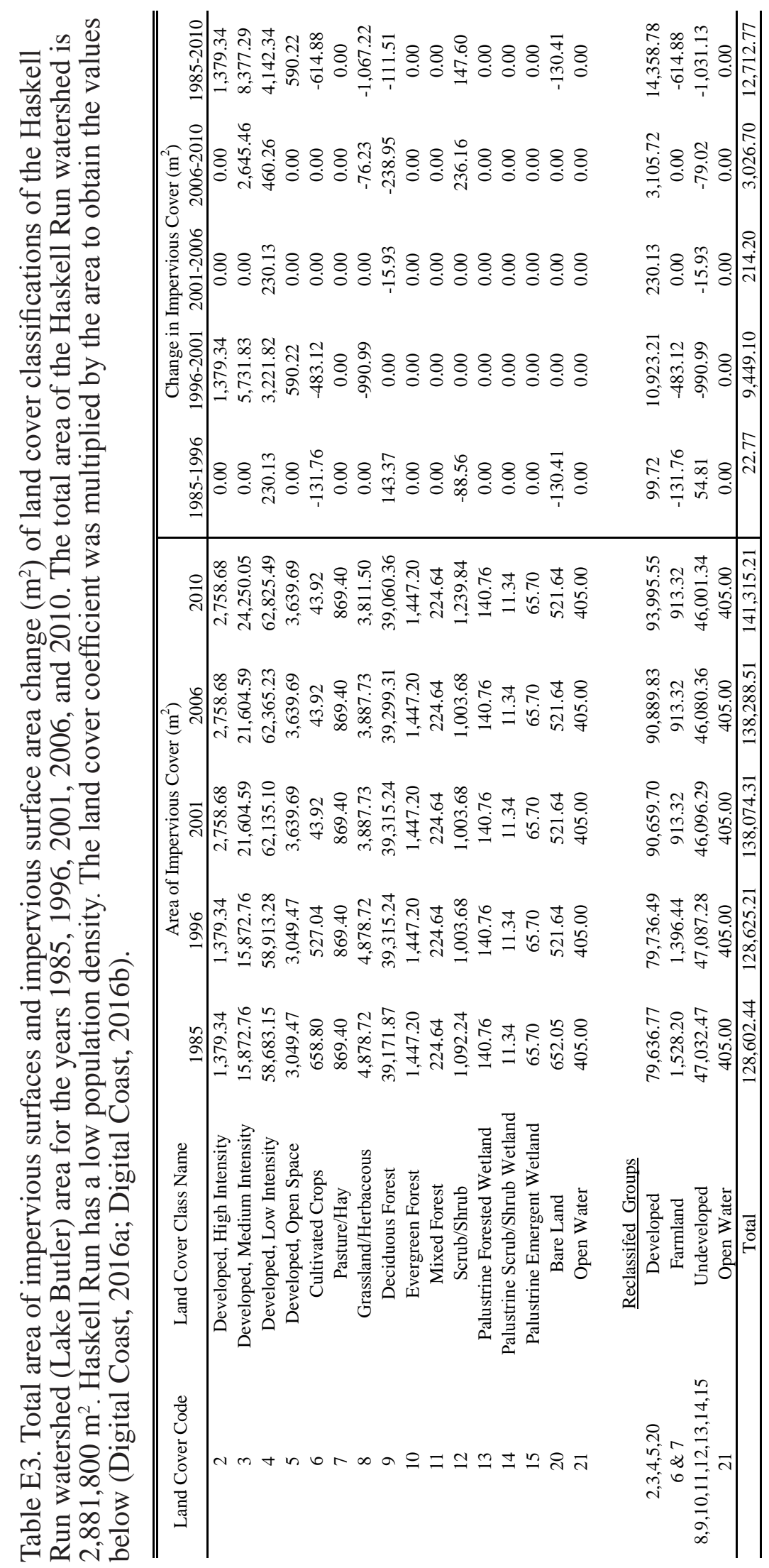




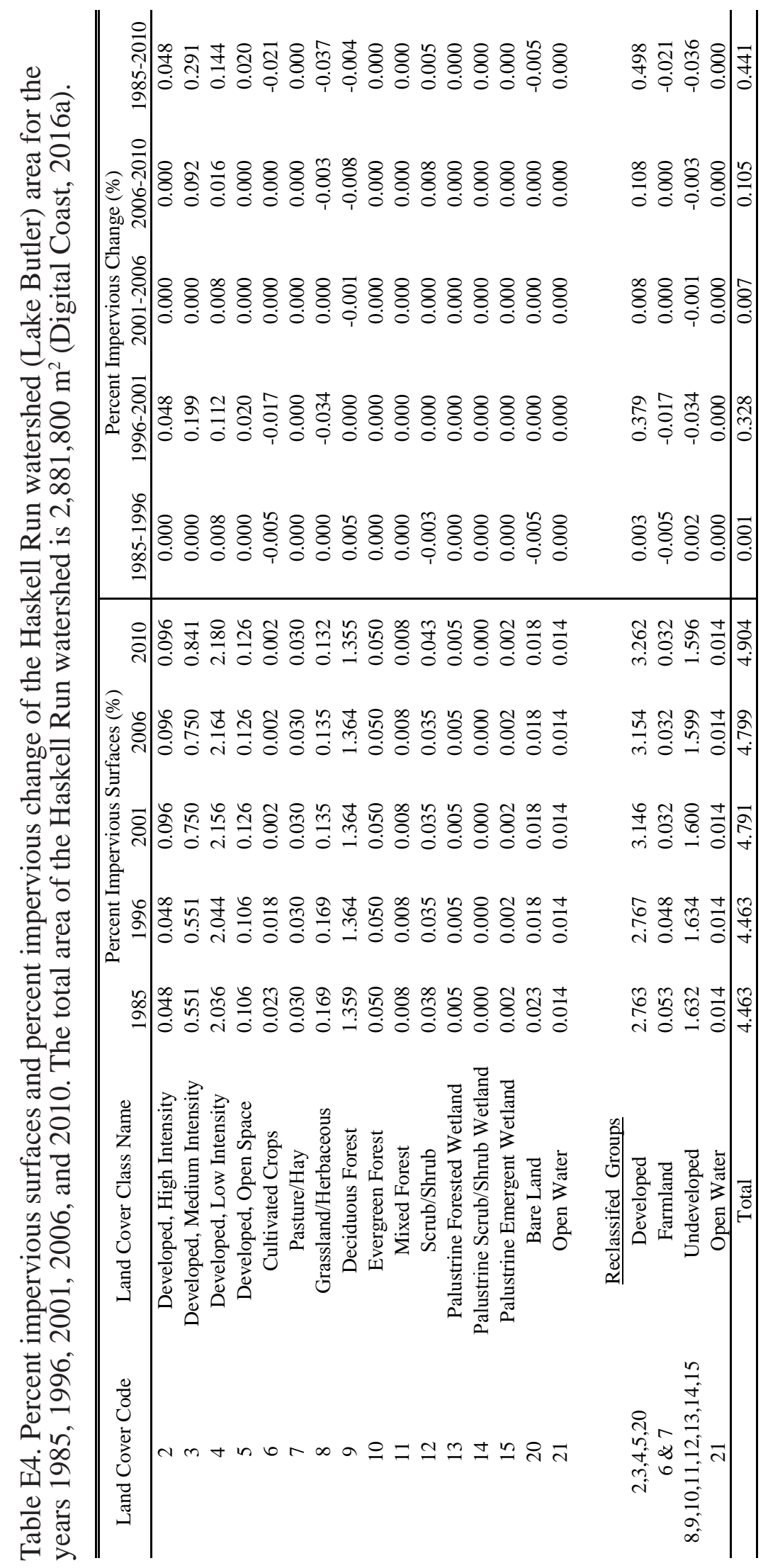




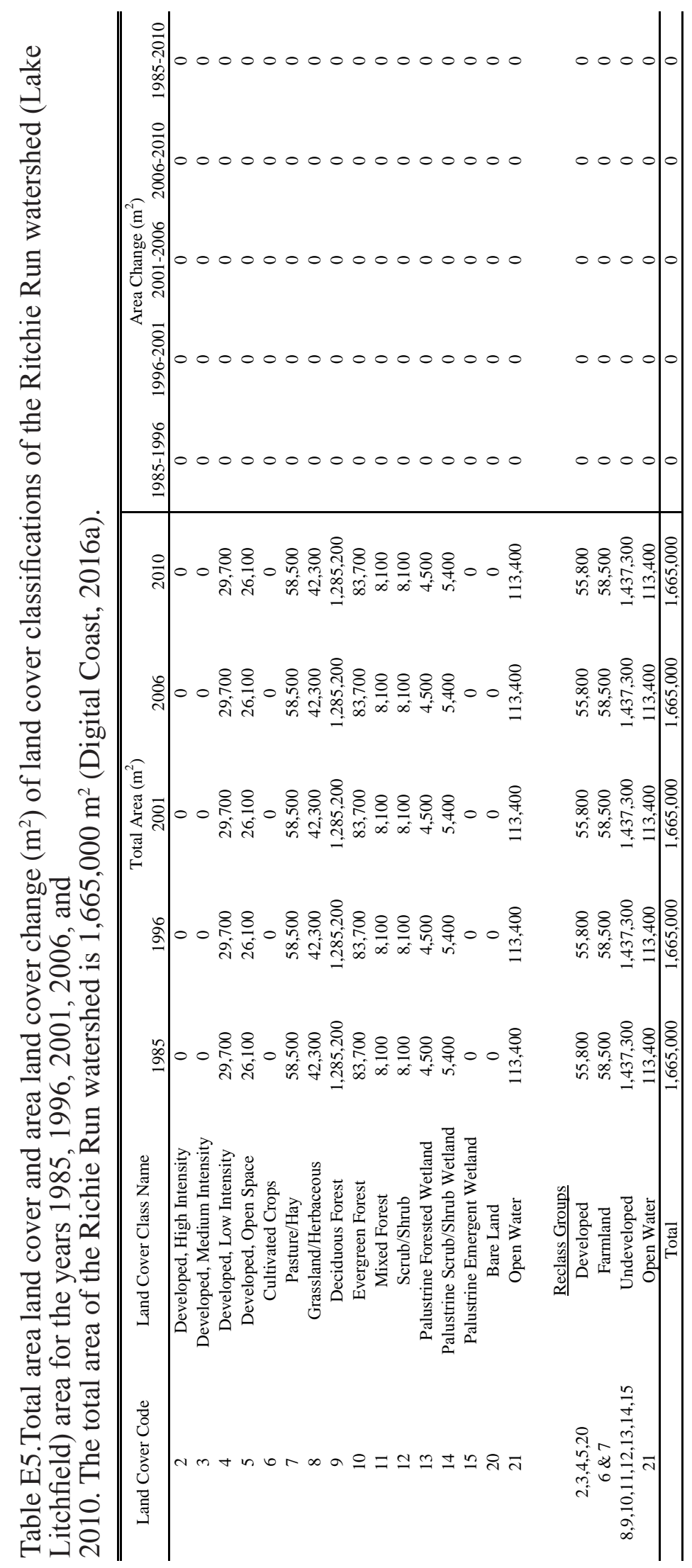




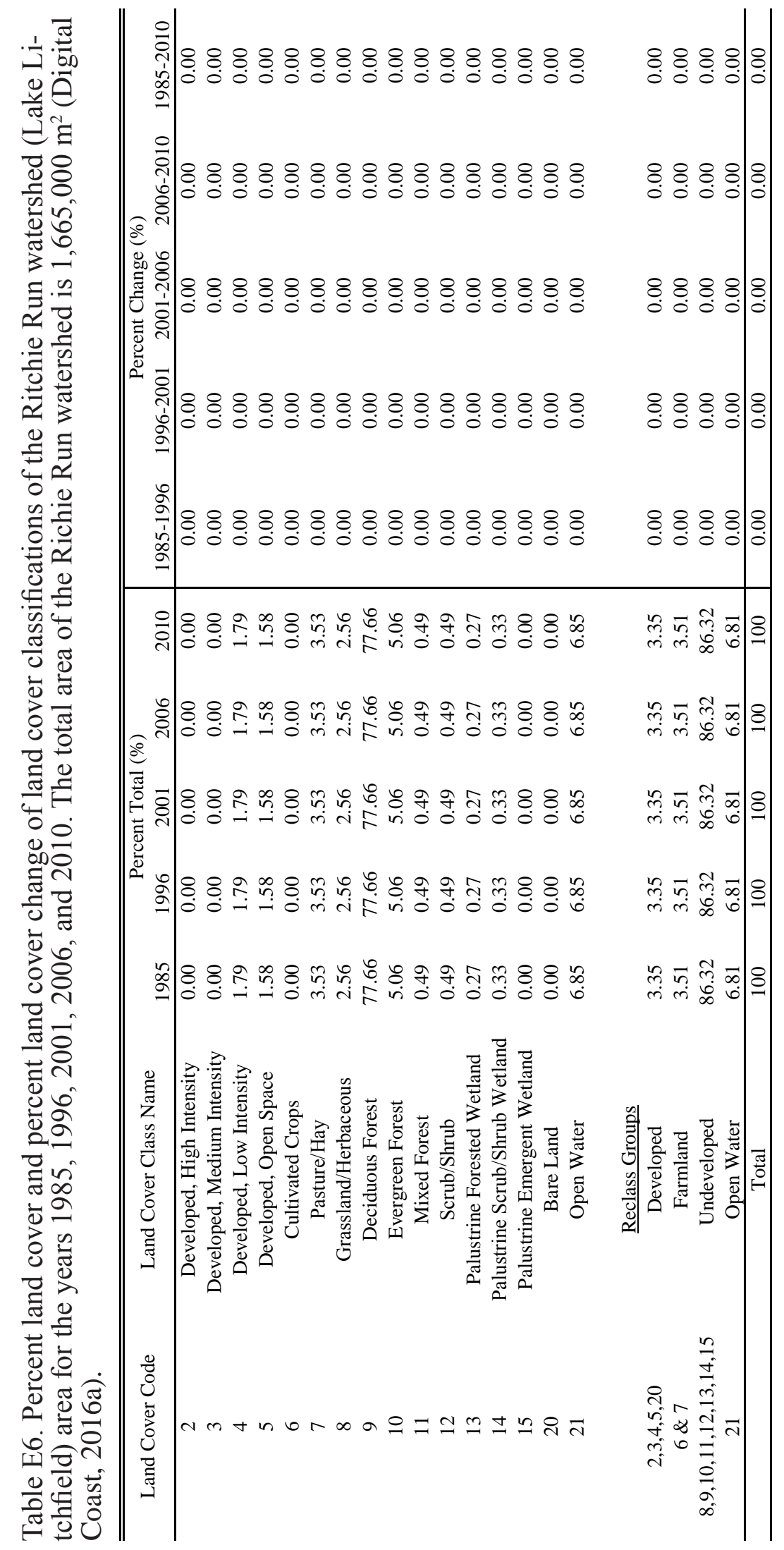




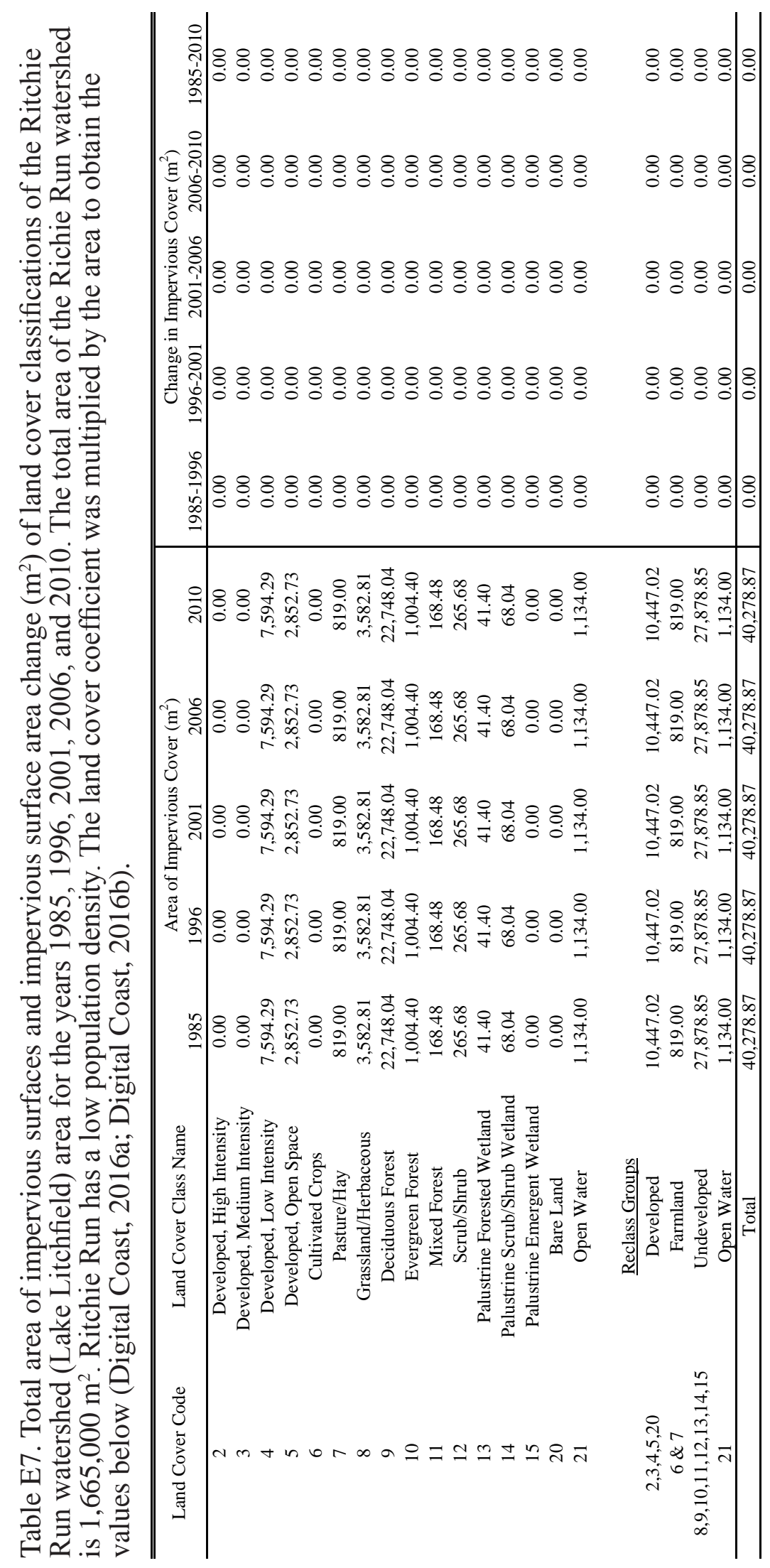




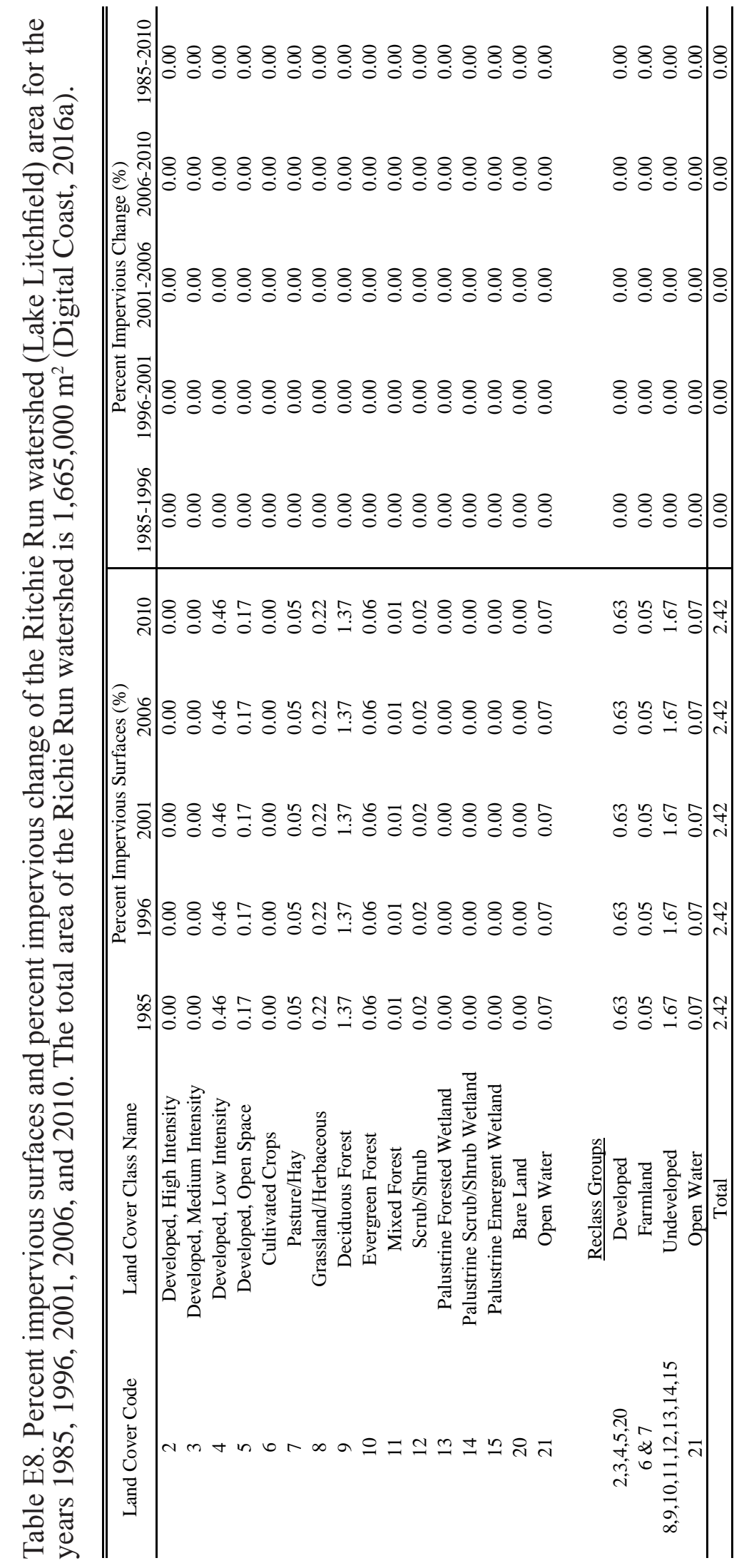




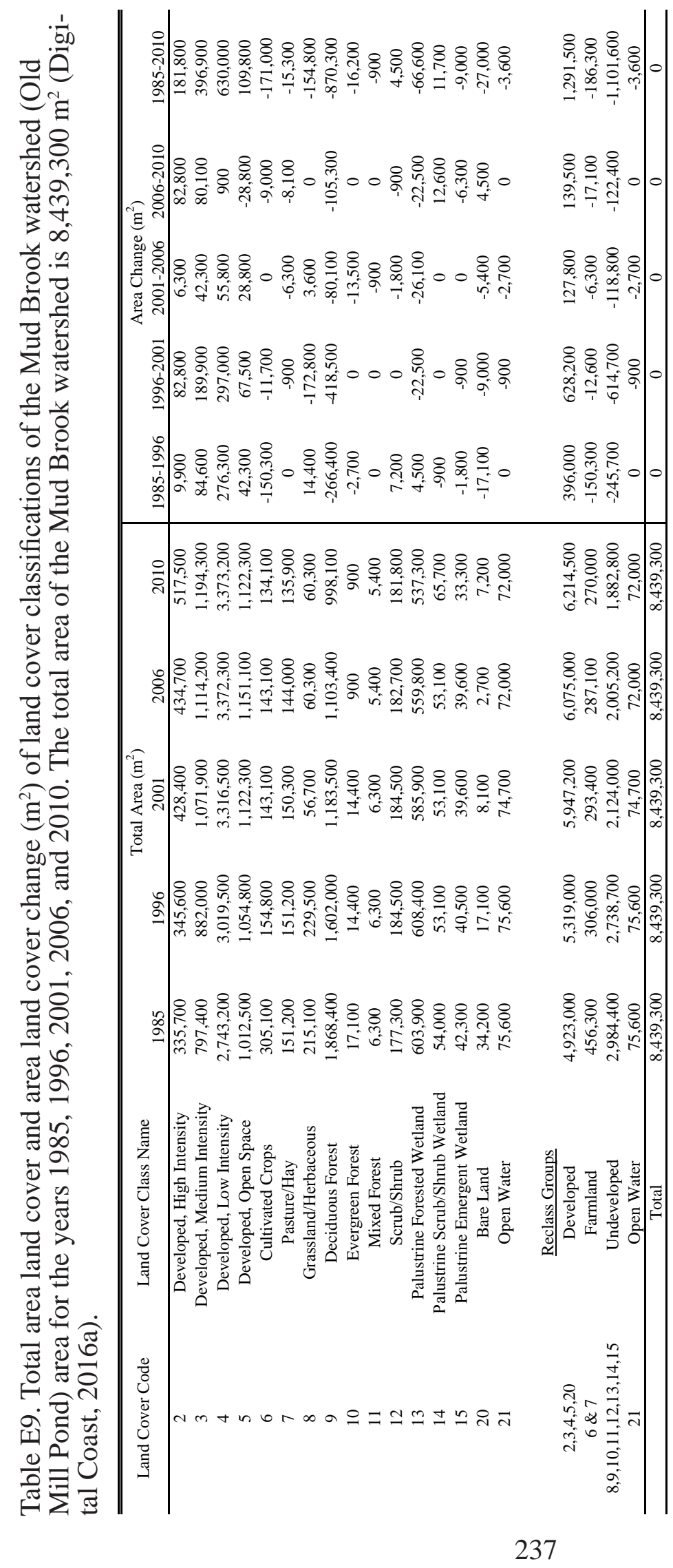




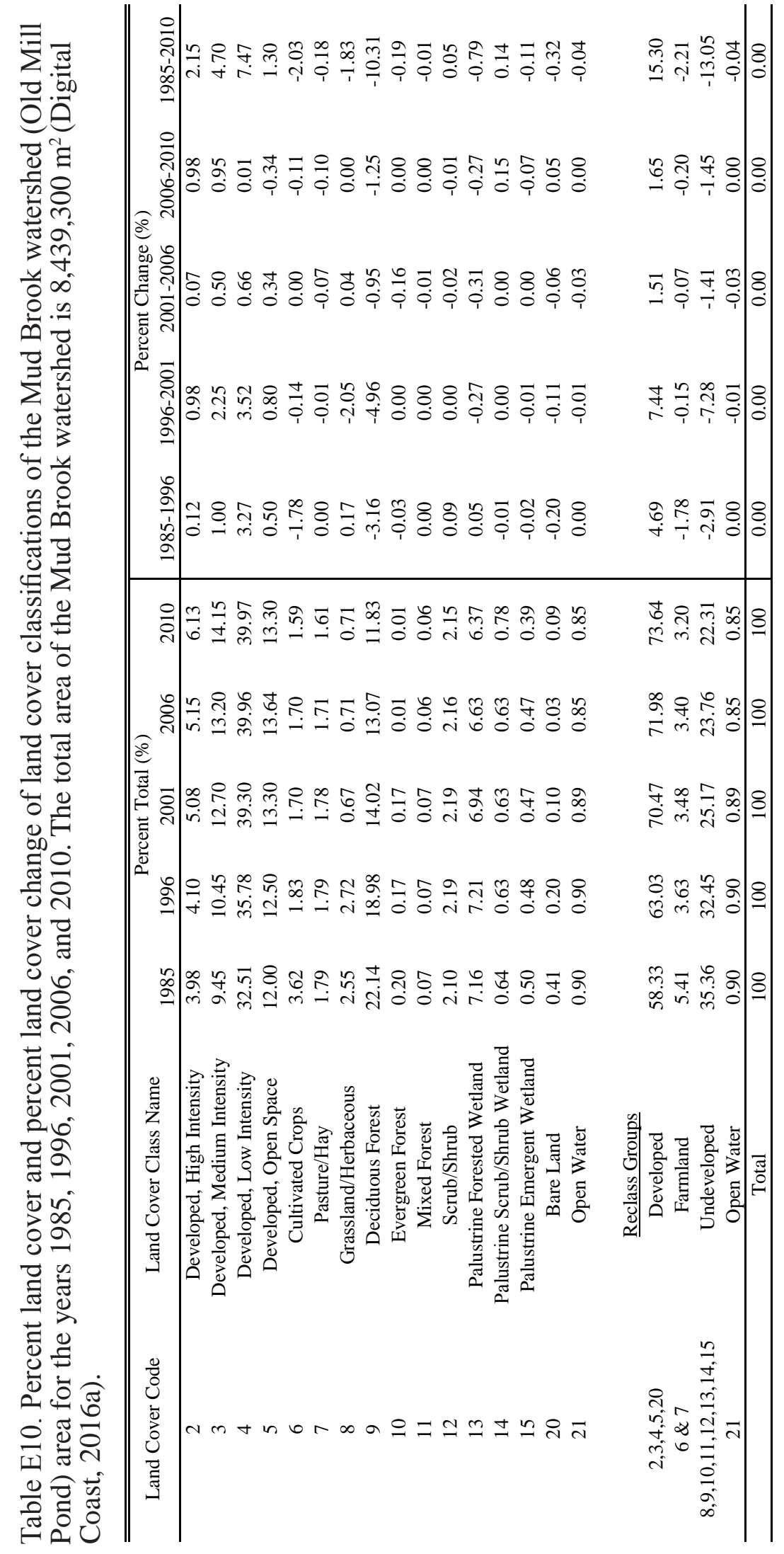




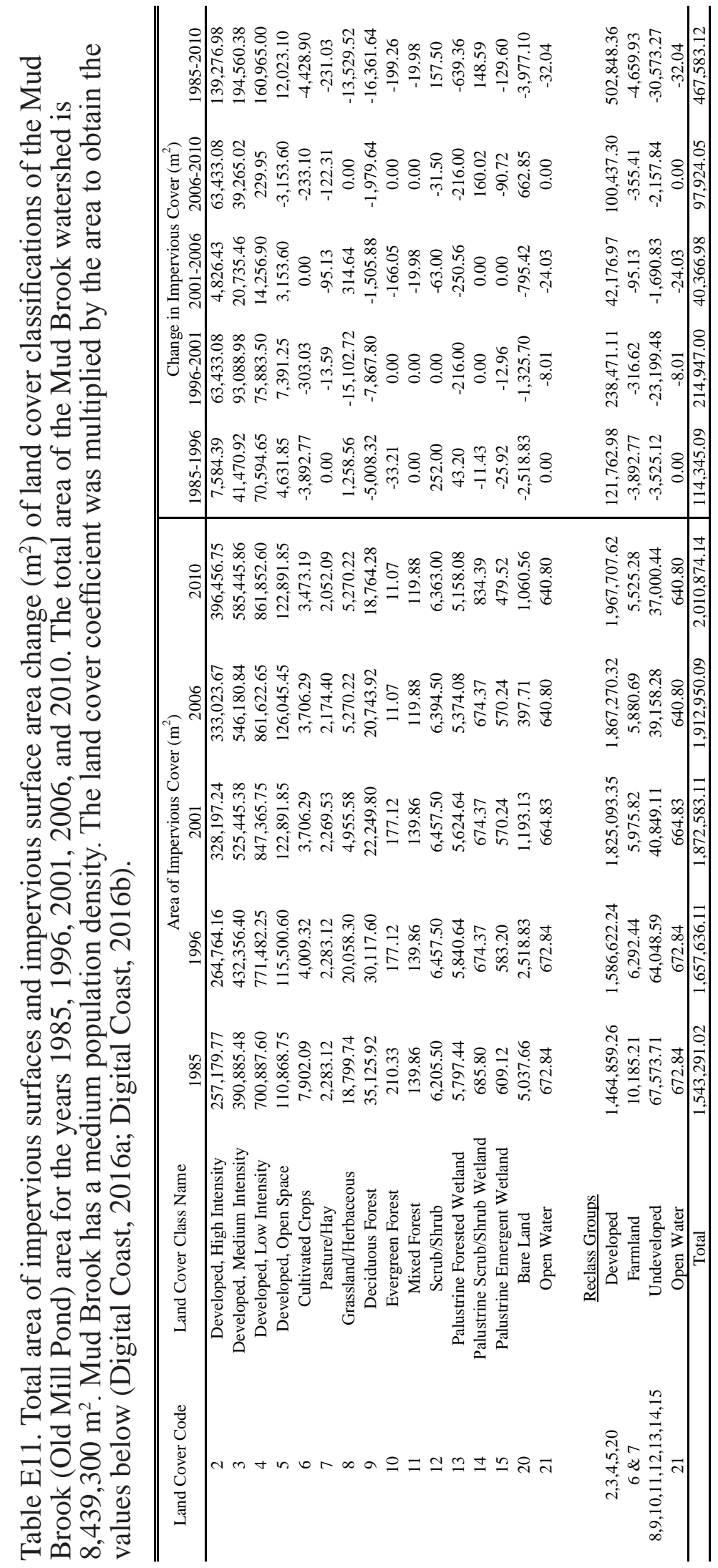




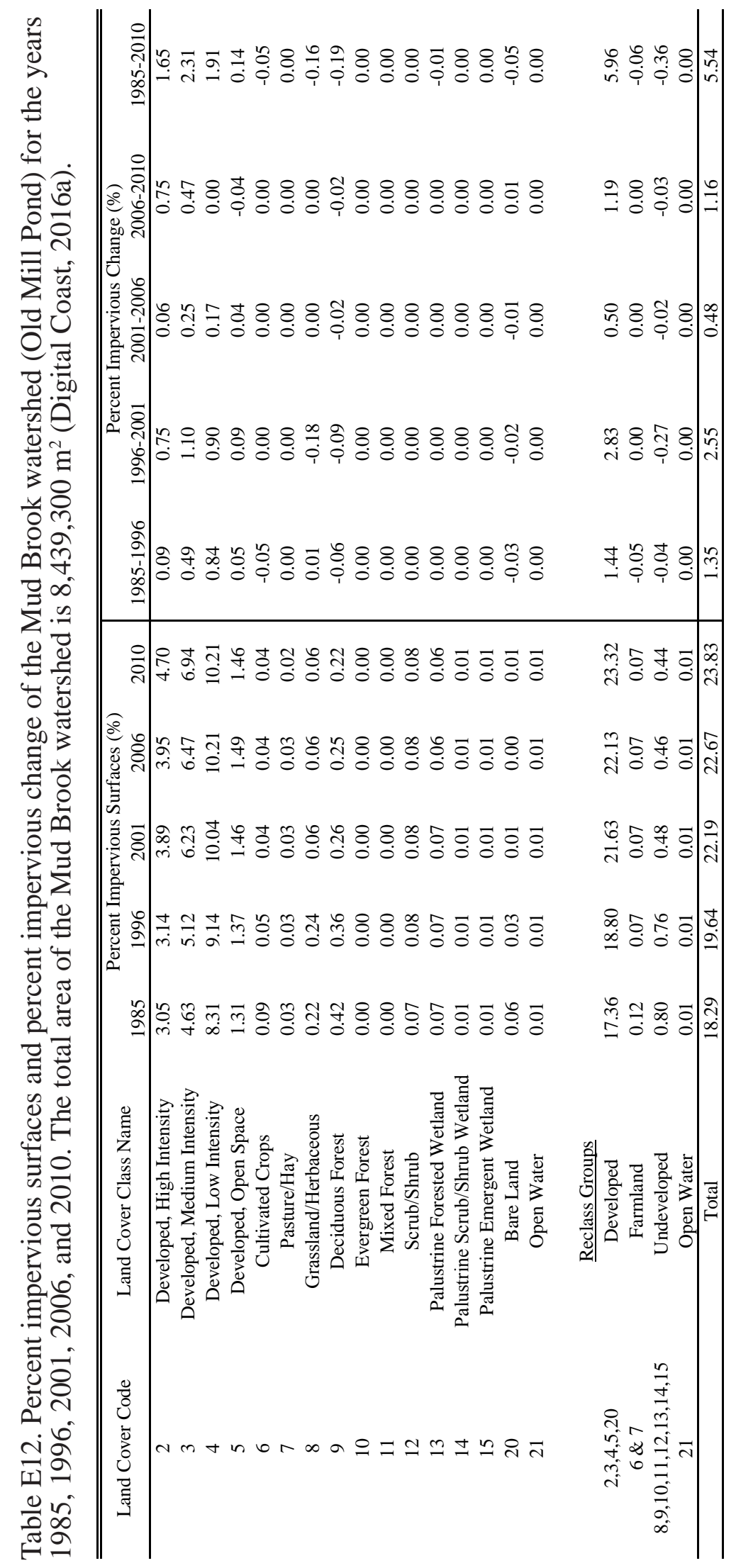




\section{APPENDIX F GRAIN SIZE DATA FOR SEDIMENT CORE AND SURFACE SAMPLES FOR LAKE BUTLER, LAKE LITCHFIELD, AND OLD MILL POND}

The Folk (1980) grain size method was used on 19 repressive samples from the sediment cores and surface samples of all sites. The pipette method was used on mud samples. Sand and gravel samples were measured by using the rotap sieving method divided into $0.5 \Phi$ increments. 


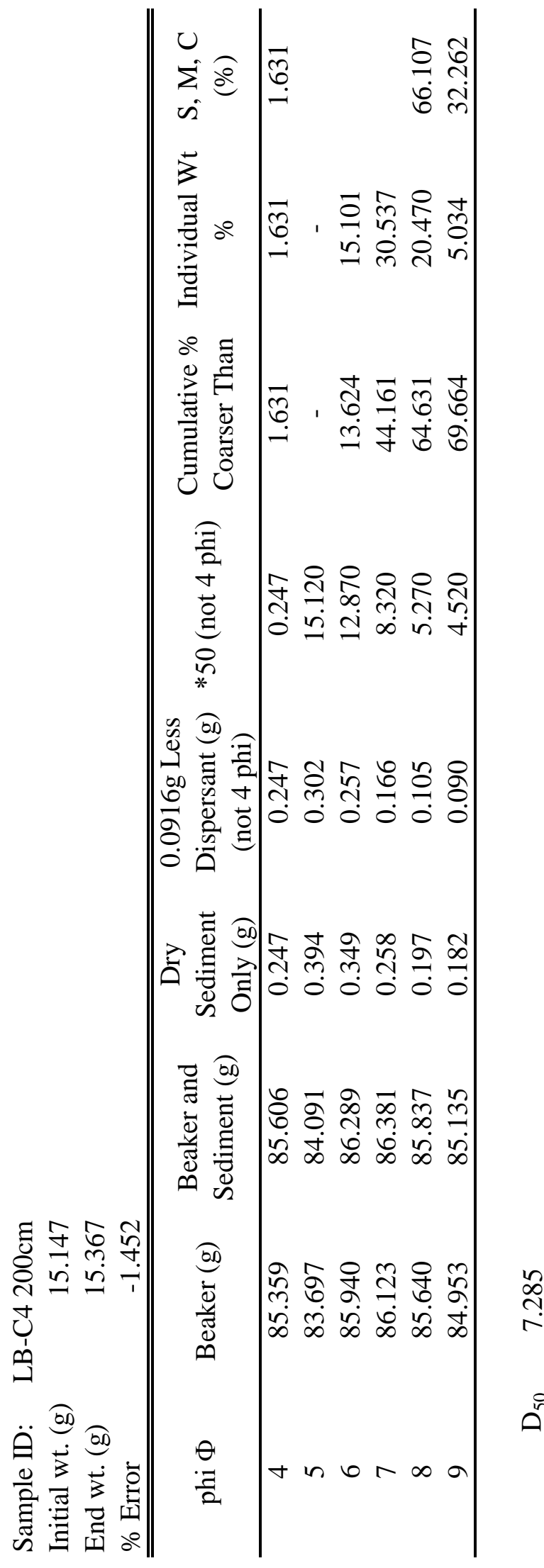




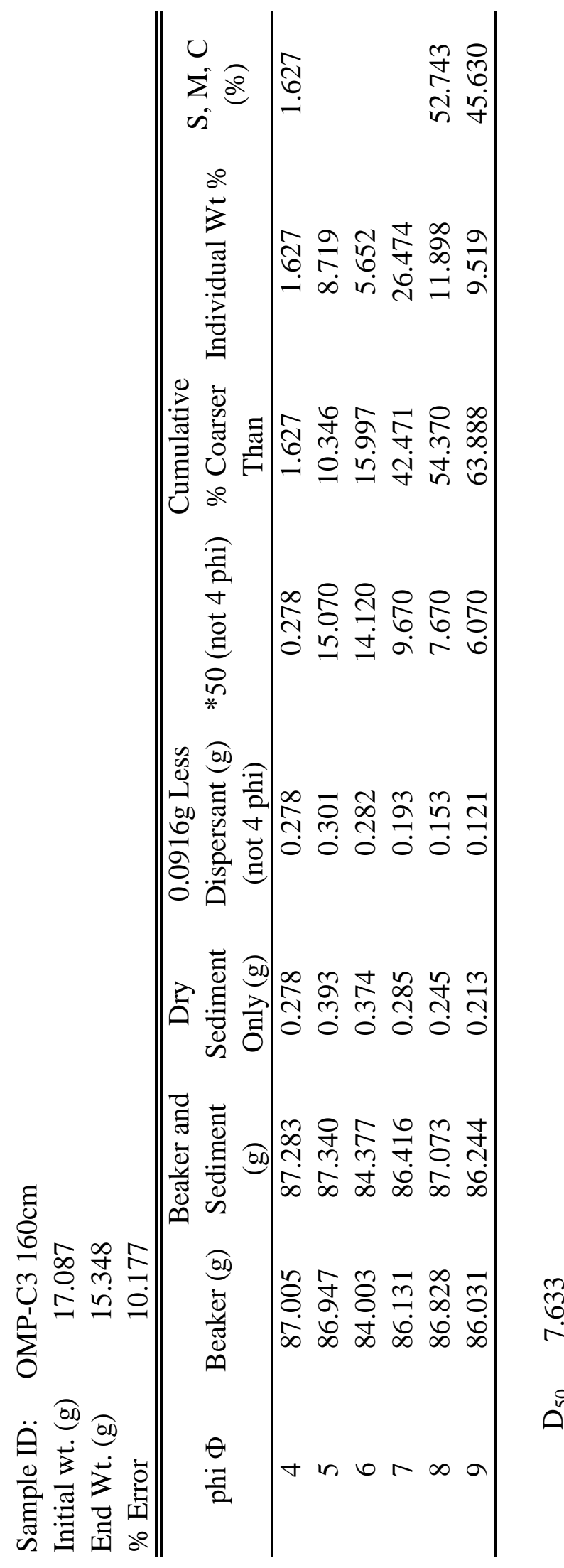




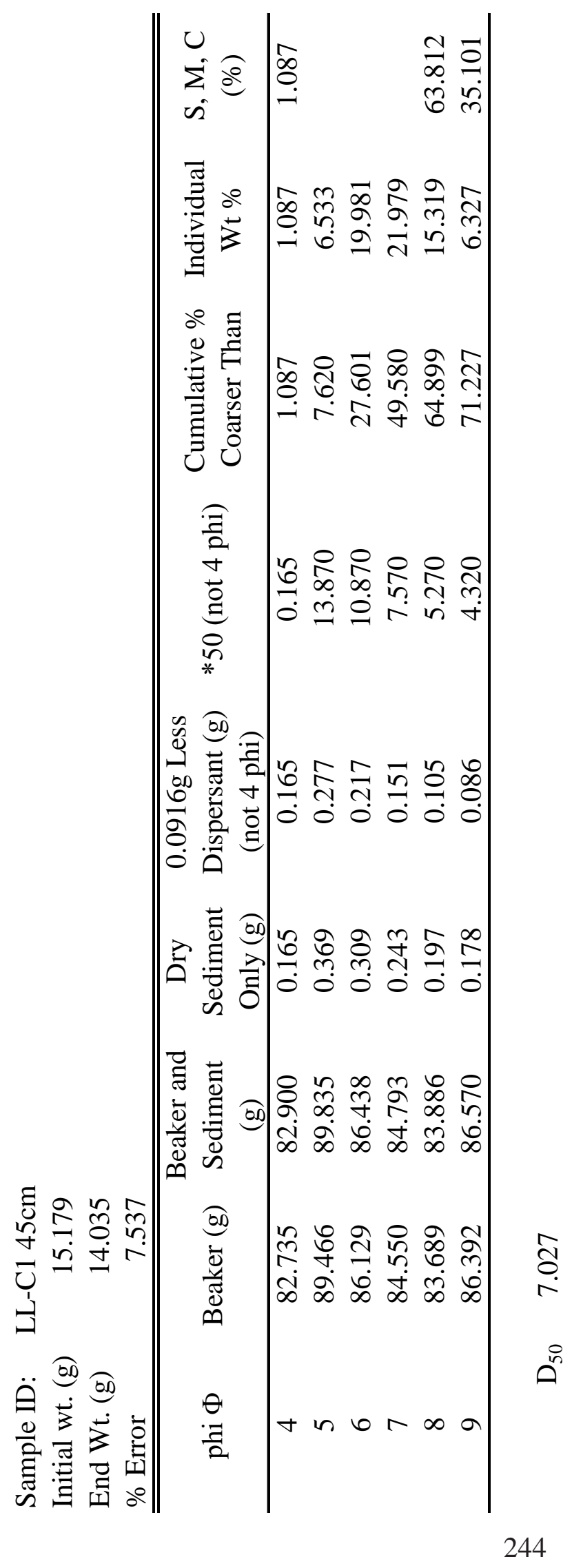




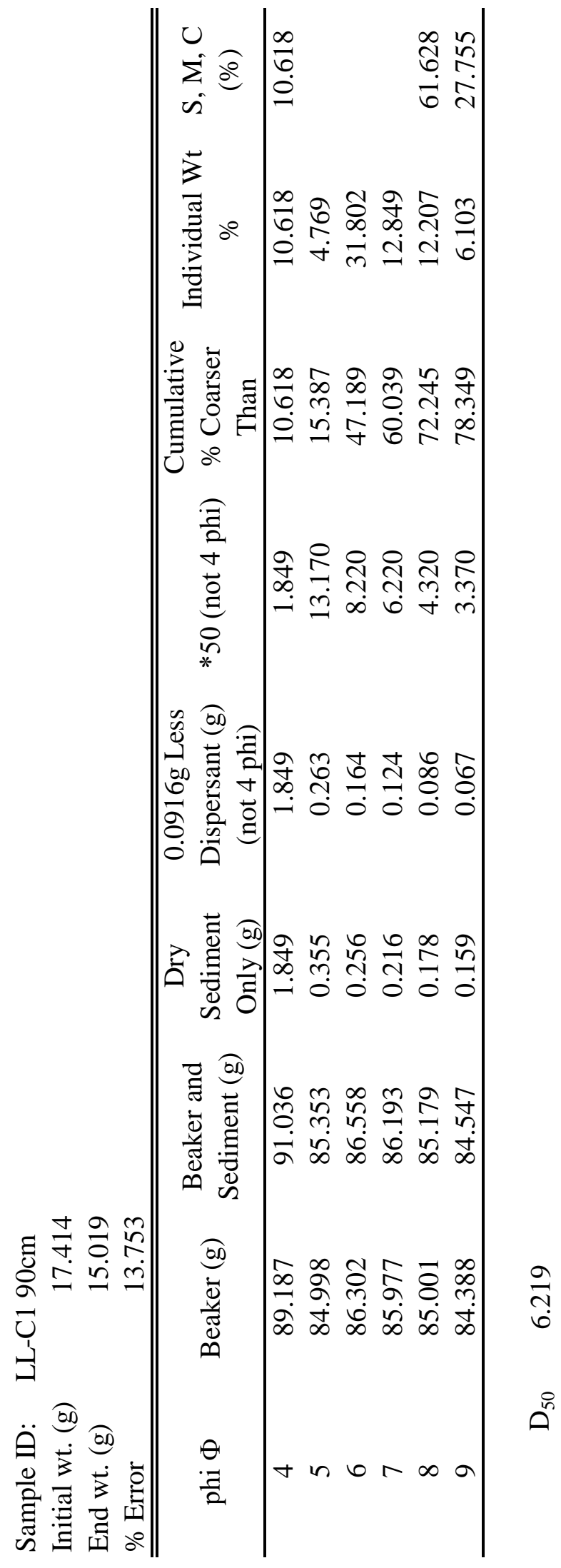




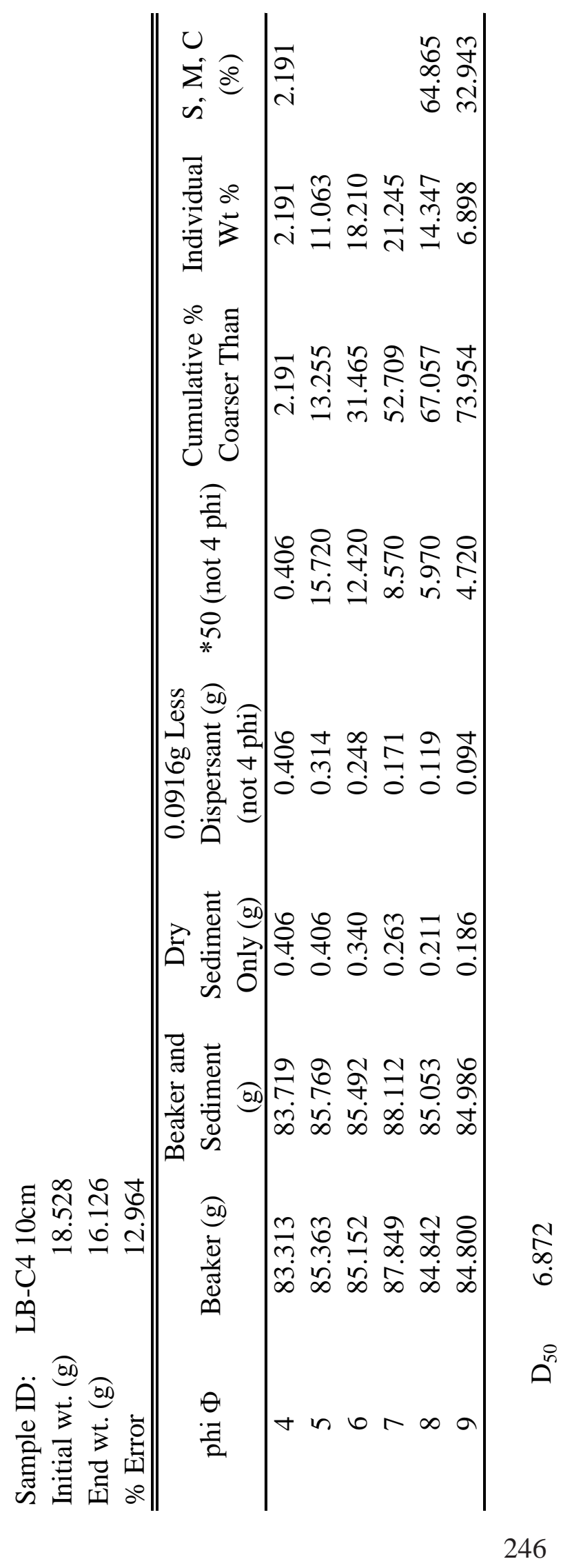




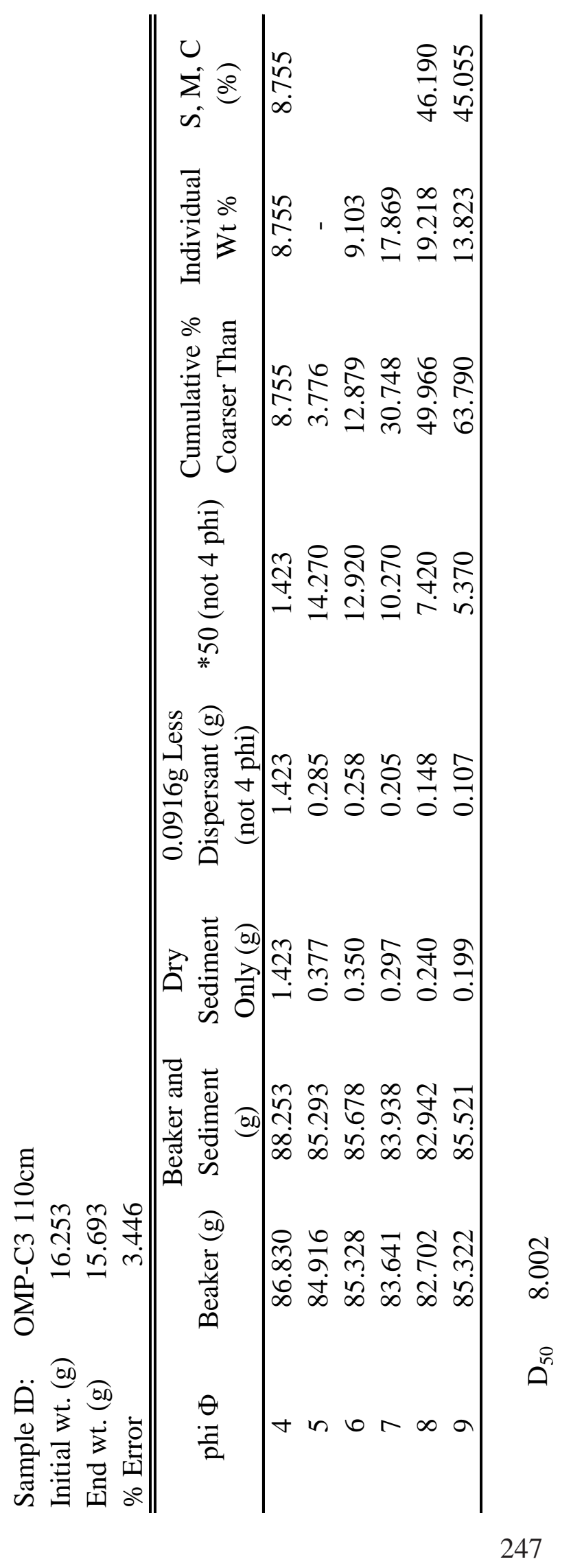




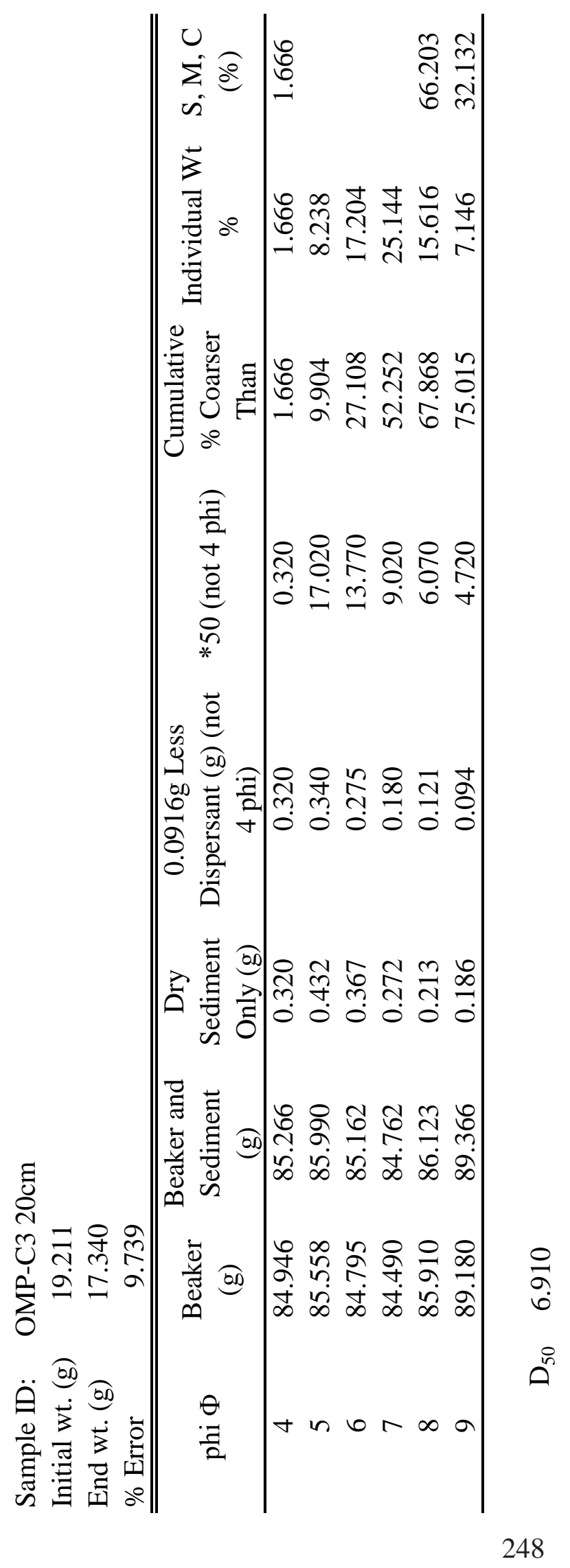




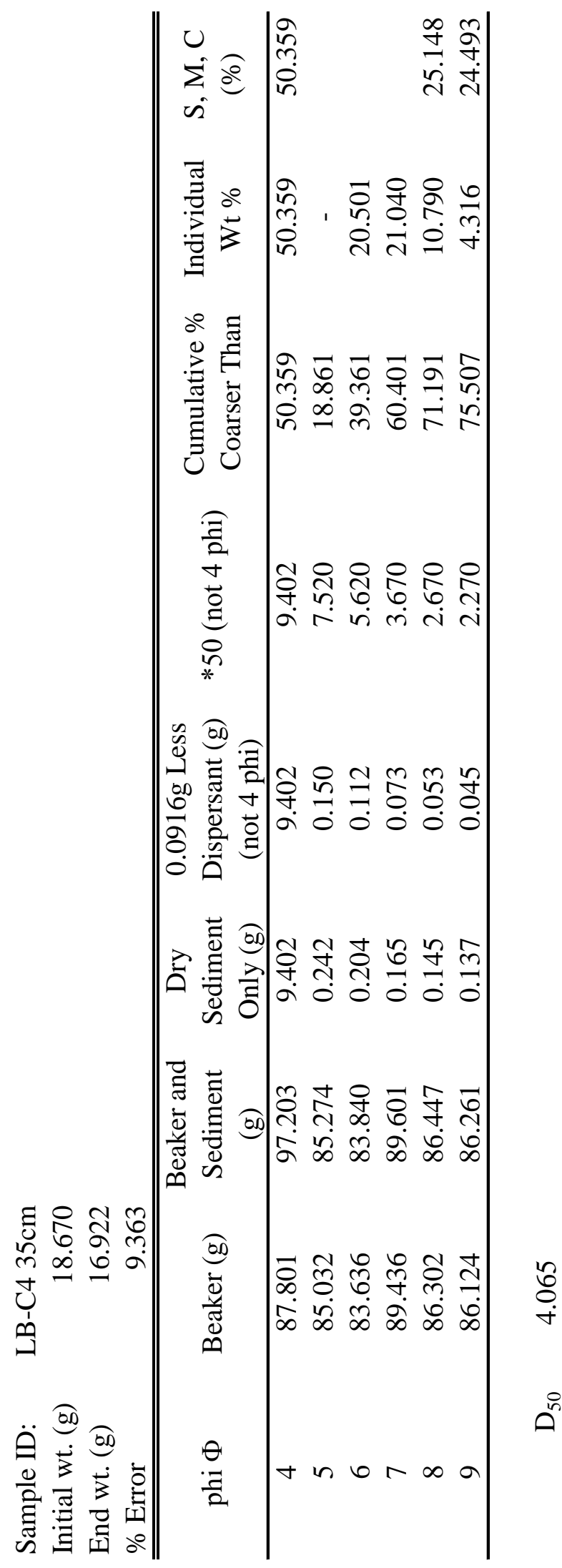




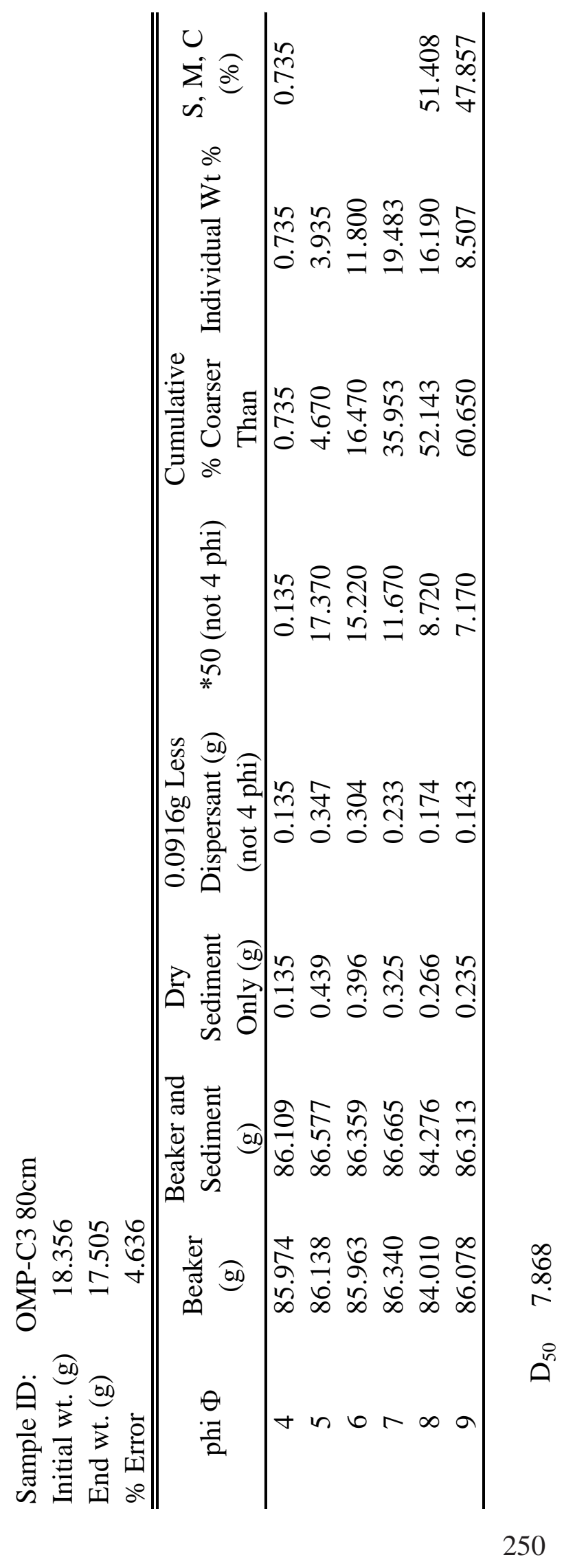




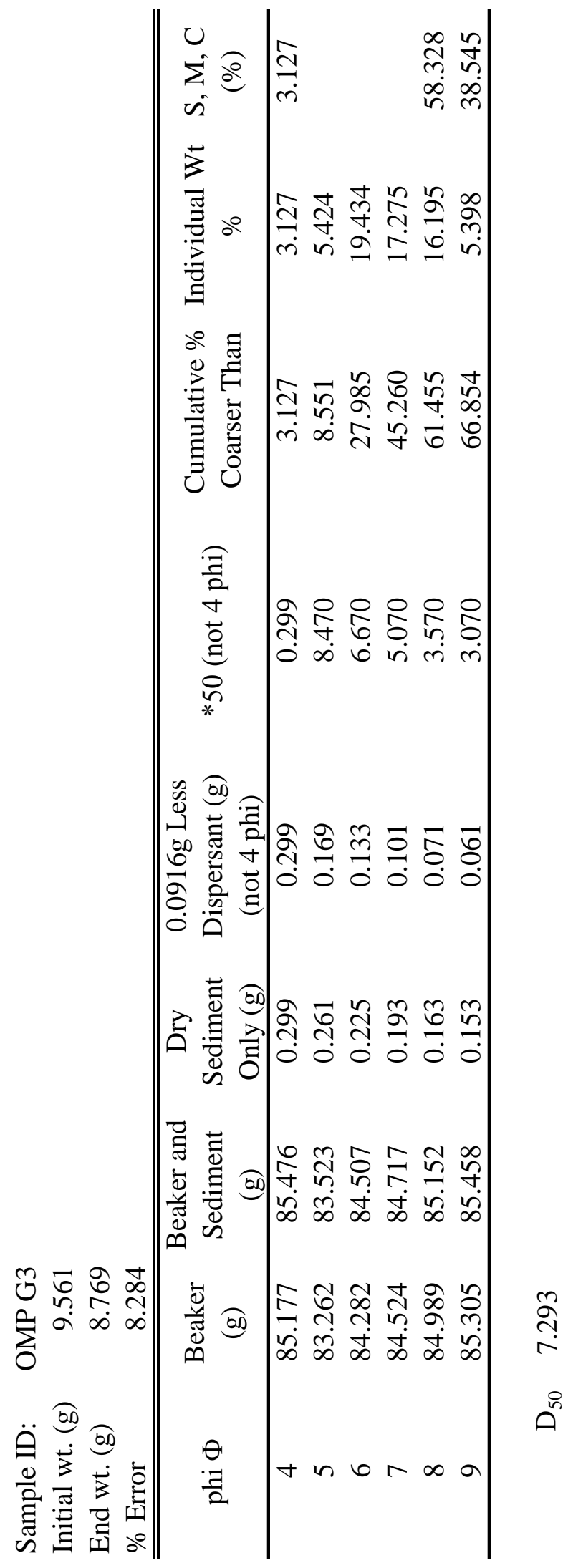




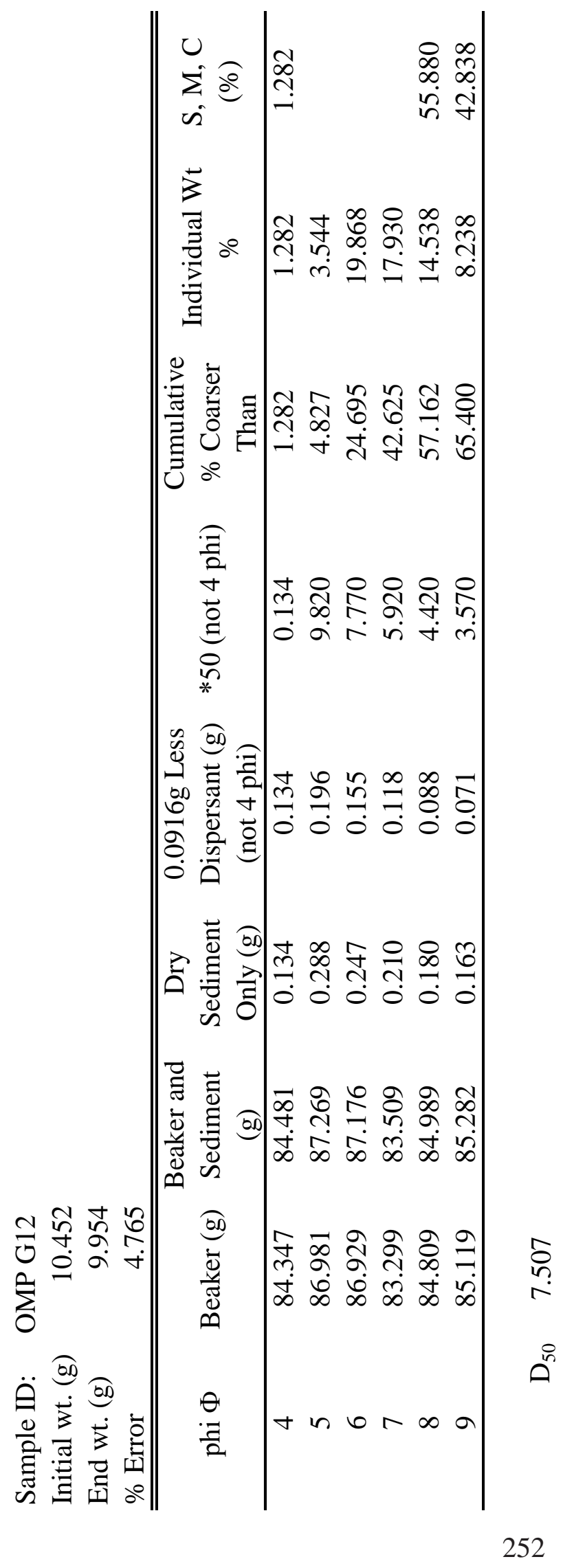




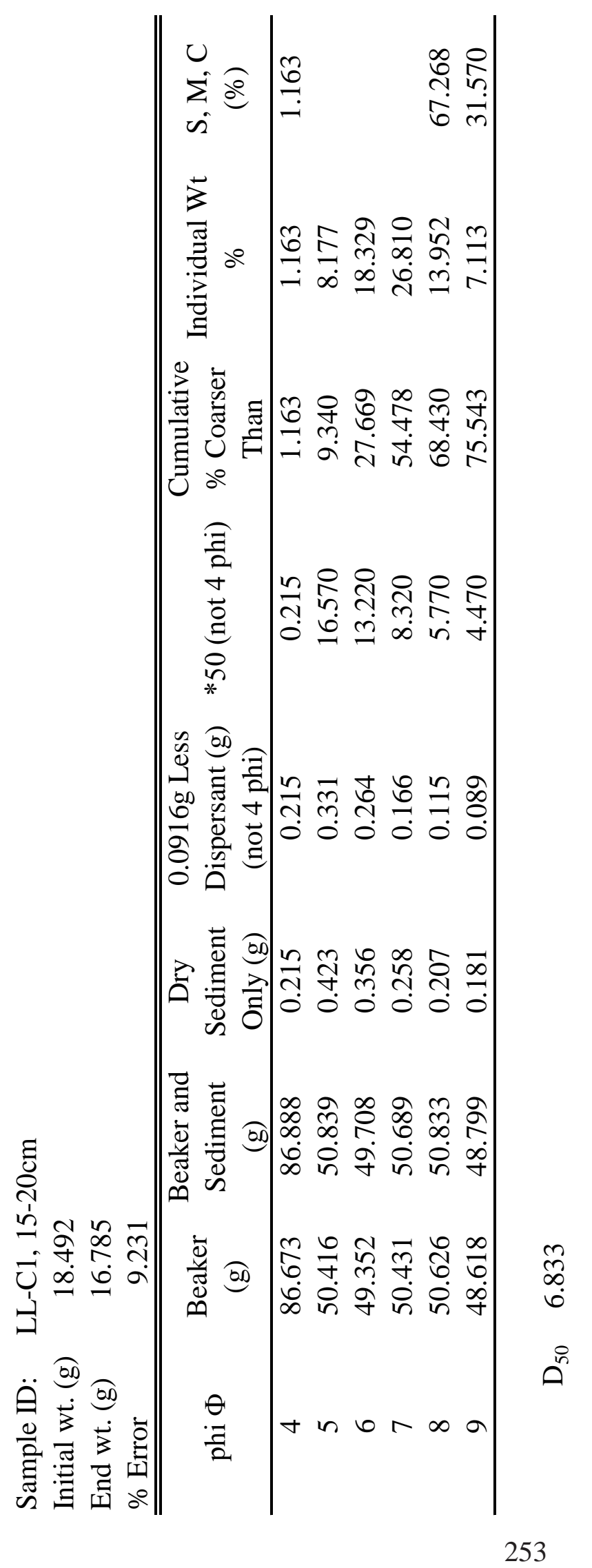




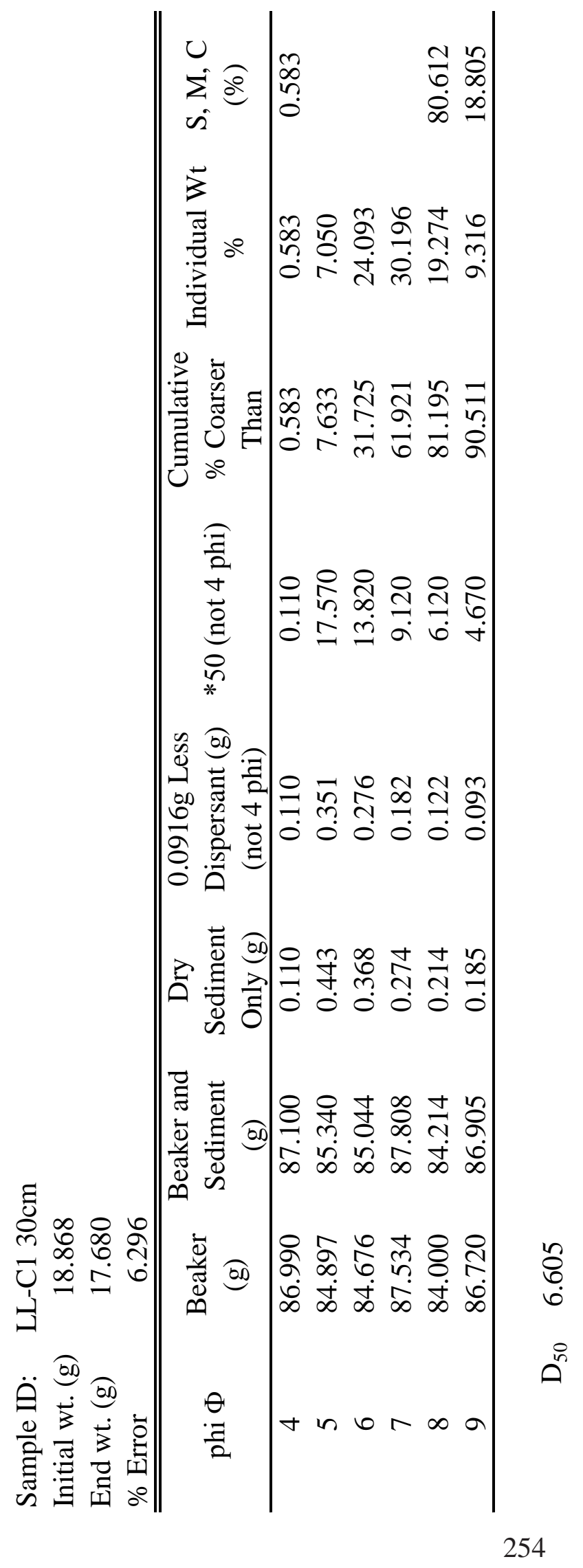




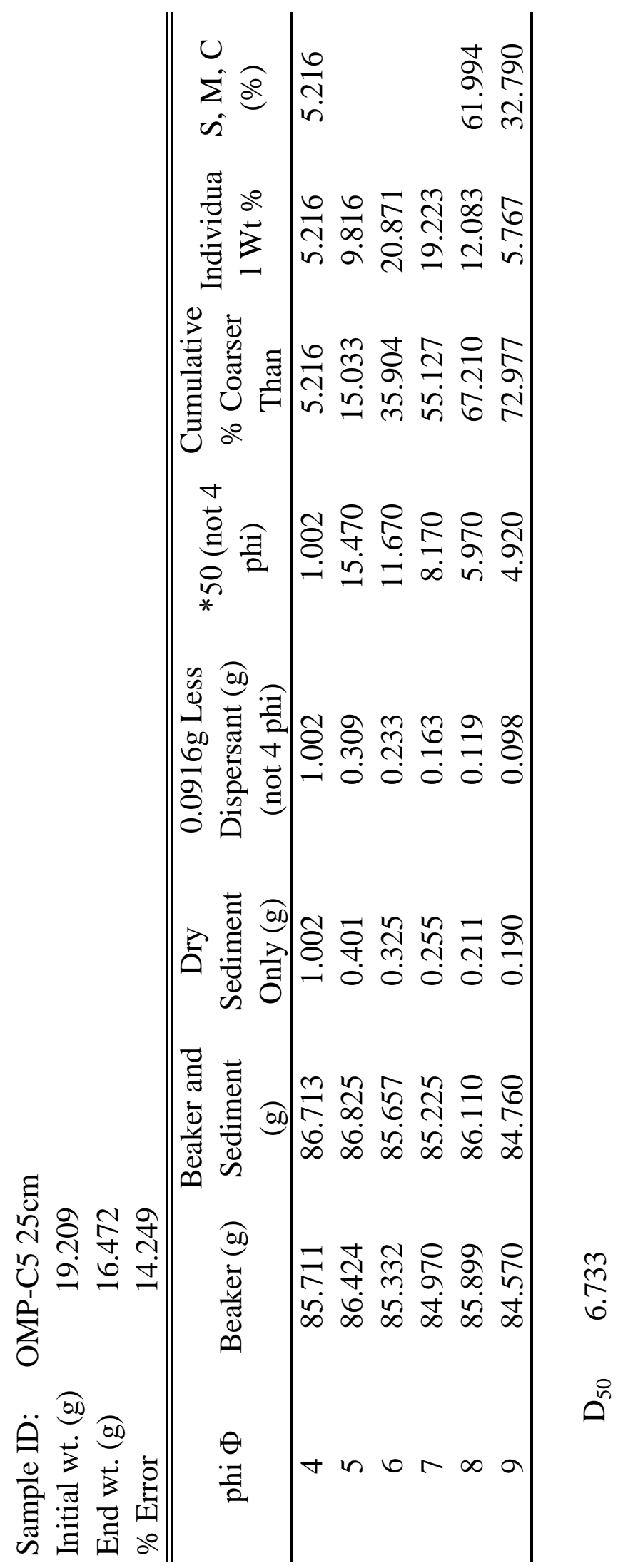




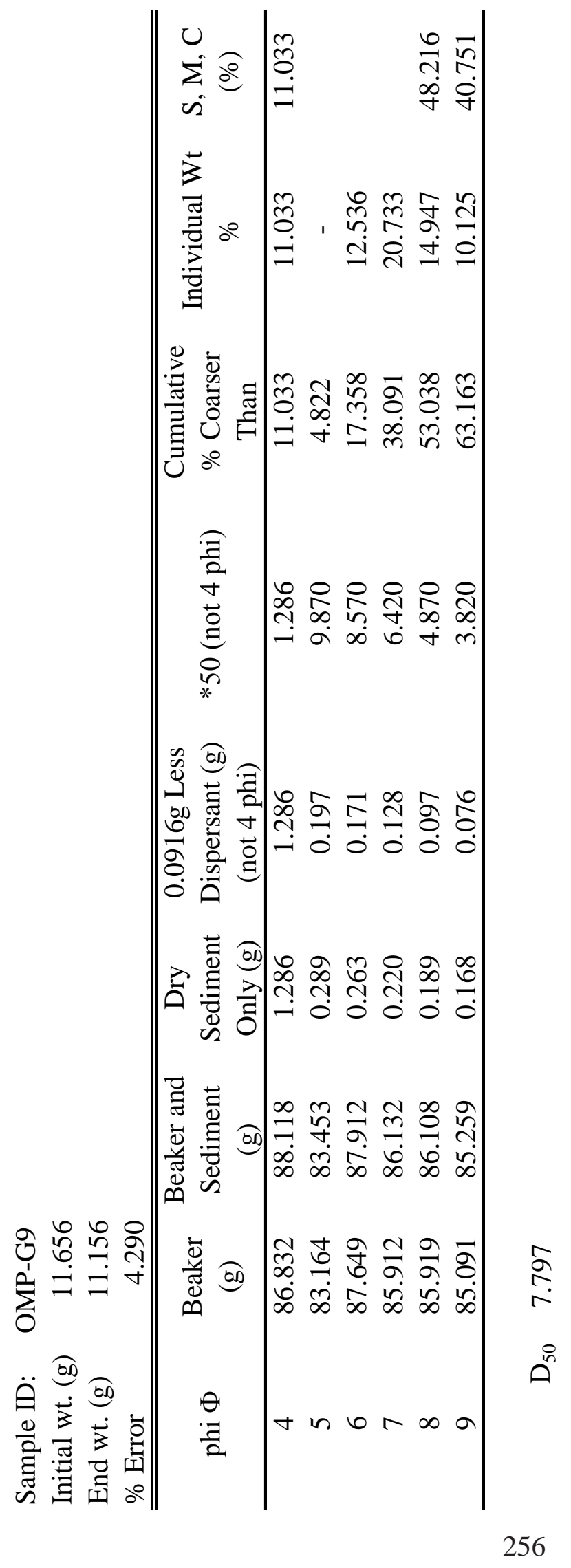




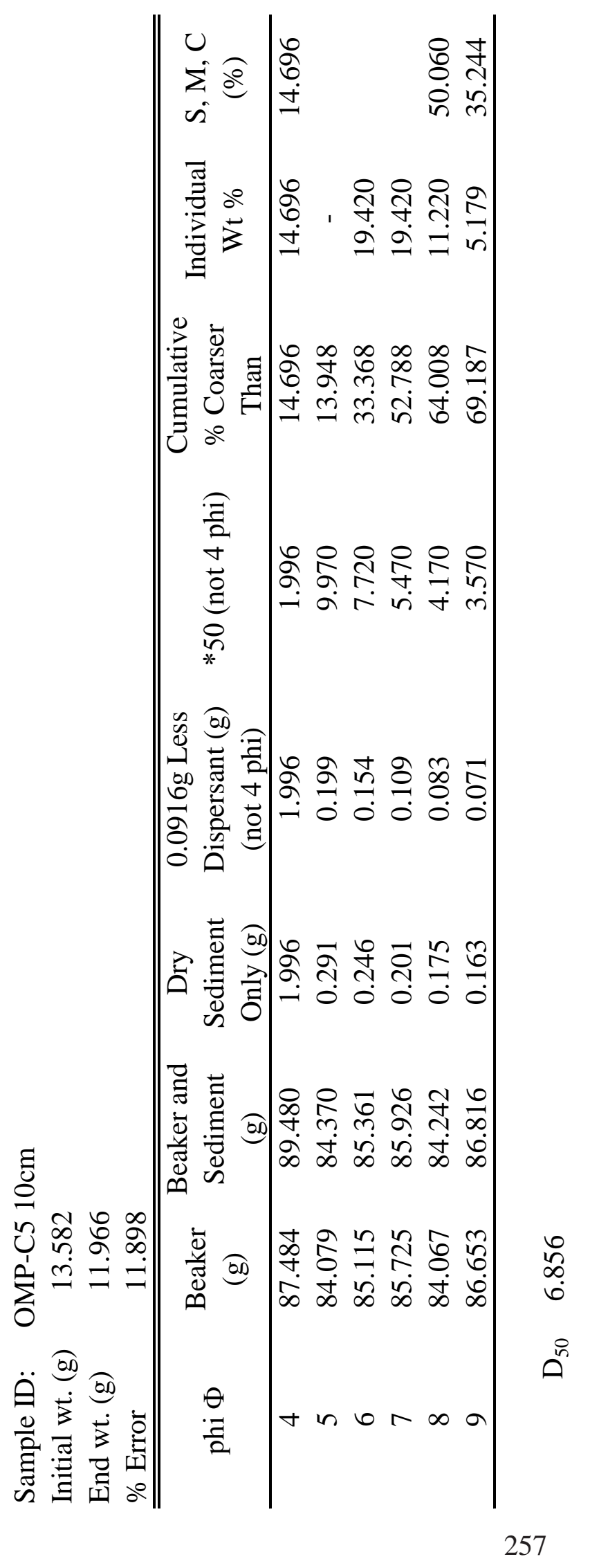




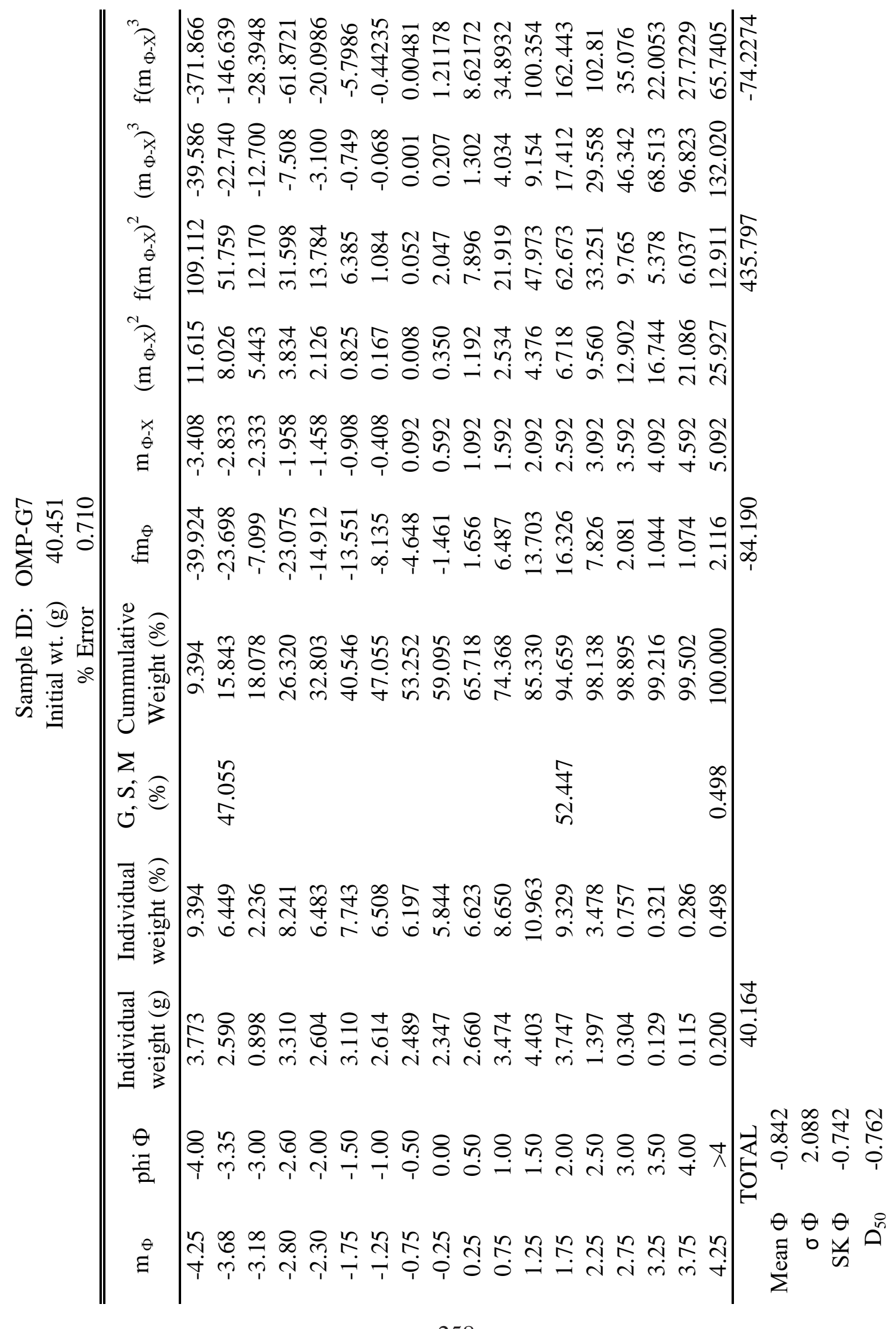




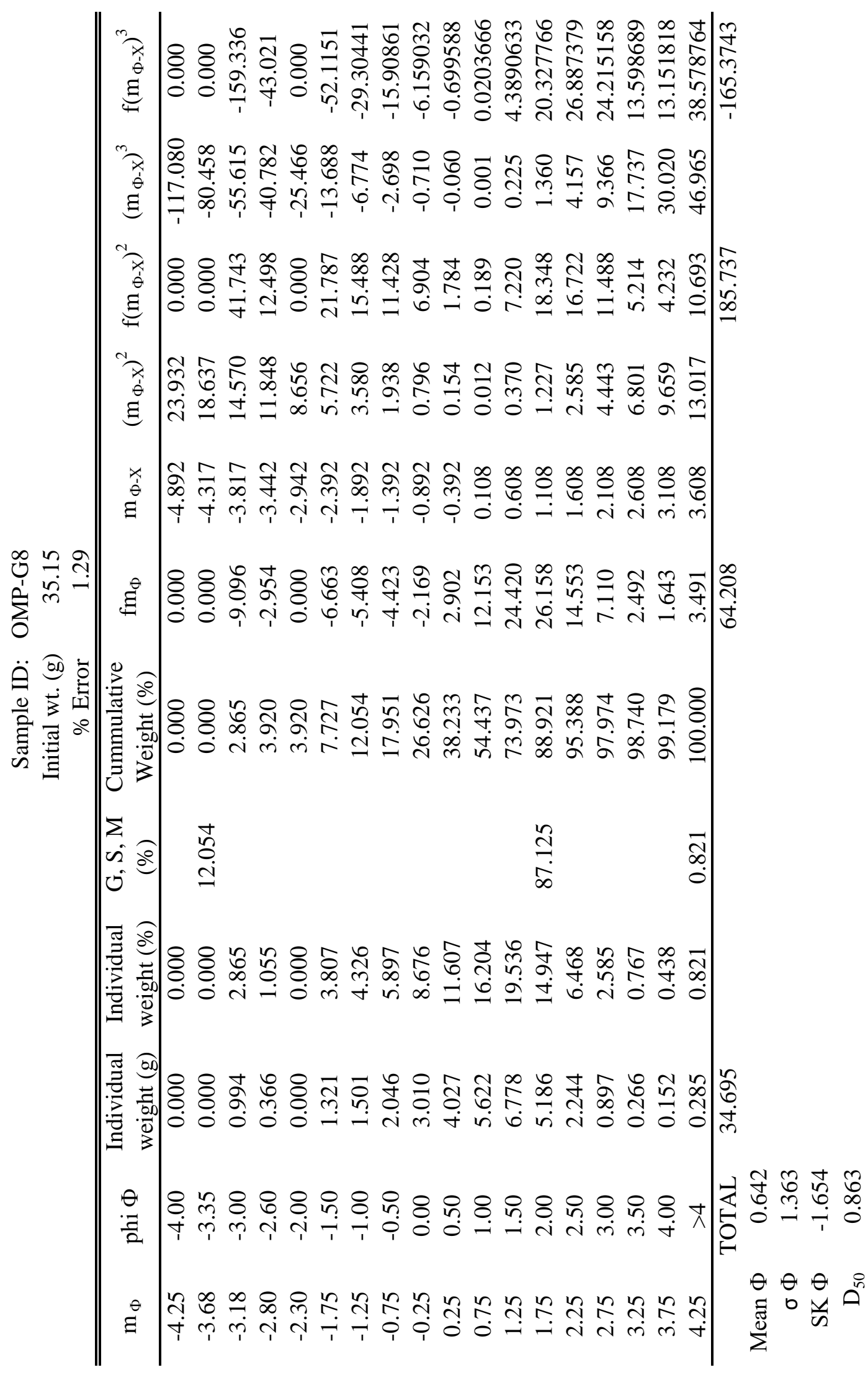




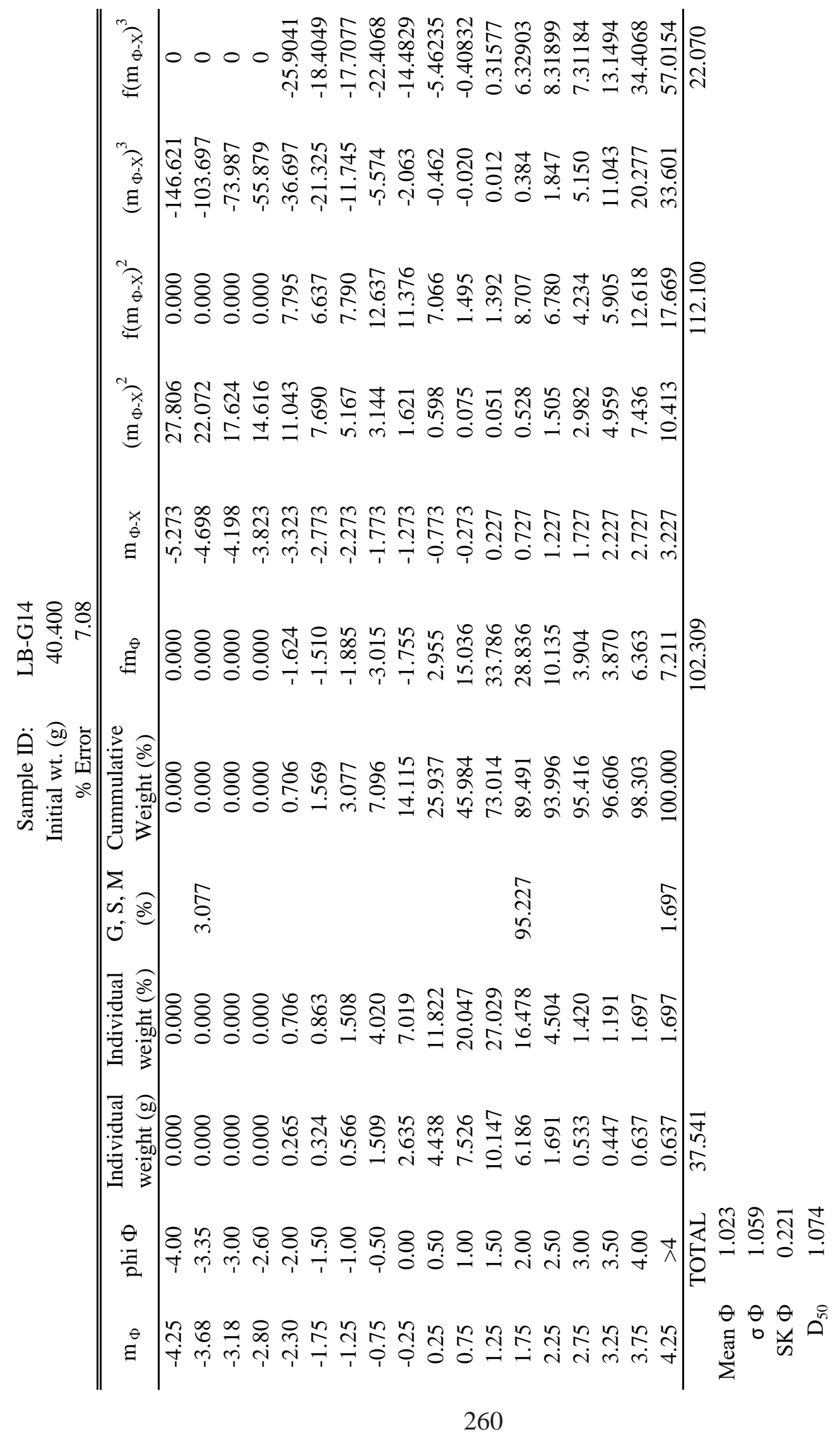

